\title{
Disposability Assessment: Aluminum-Based Spent Nuclear Fuel Forms
}

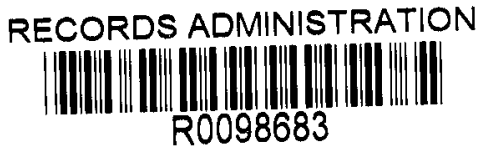

by

D. W. Vinson

Westinghouse Savannah River Company

Savannah River Site

Aiken, South Carolina 29808

This paper was prepared in connection with work done under the above contract number with the U.S.

Department of Energy. By acceptance of this paper, the publisher and/or recipient acknowledges the U. S. Government's right to retain a nonexclusive, royalty-free license in and to any copyright covering this paper, along with the right to reproduce and to authorize others to reproduce all or part of the copyrighted paper. 


\section{DISPOSABILITY ASSESSMENT: ALUMINUM-BASED SPENTNUCLEAR FUELFORMS}

Savannah River Technology Center

Strategic Materials Technology Department

Materials Technology Section

Publication Date: June 1998

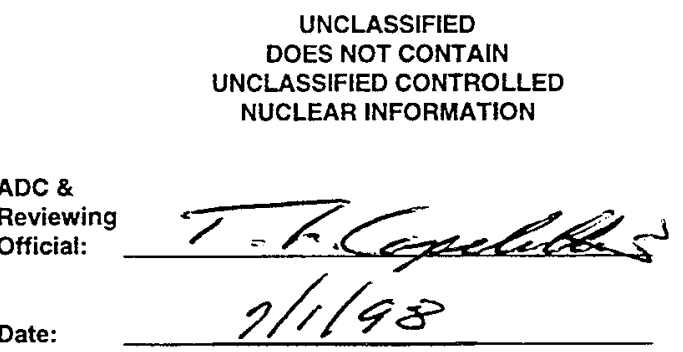

\section{Westinghouse Savannah River Company Savannah River Site Aiken, SC 29808}

This document was prepared in connection with work done under Contract No. DE-AC09$96 S R 18500$ with the U. S. Department of Energy 


\section{DISCLAIMER}

This report was prepared as an account of work sponsored by an agency of the United States Government. Neither the United States Government nor any agency thereof, nor any of their employees, makes any warranty, express or implied, or assumes any legal liability or responsibility for the accuracy, completeness, or usefulness of any information, apparatus, product, or process disclosed, or represents that its use would not infringe privately owned rights. Reference herein to any specific commercial product, process, or service by trade name, trademark, manufacturer, or otherwise does not necessarily constitute or imply its endorsement, recommendation, or favoring by the United States Government or any agency thereof. The views and opinions of authors expressed herein do not necessarily state or reflect those of the United States Government or any agency thereof.

This report has been reproduced directly from the best available copy.

Available to DOE and DOE contractors from the Office of Scientific and Technical Information, P.O. Box 62, Oak Ridge, TN 37831; prices available from (615) 576-8401.

Available to the public from the National Technical Information Service, U.S. Department of Commerce; 5285 Port Royal Road, Springfield, VA 22161. 
DOCUMENT: $\quad$ WSRC-TR-98-00227

TITLE: WASTE FORM ASSESSMENT: $A L U M I N U M B A S E D$ SPENT NUCLEAR FUEL

TASKS: $\quad$ SRT-MTS-97-2030

\section{APPROVALS}




\section{CONTRIBUTORS TO WSRC-TR-98-00227}

ATP Technical Task Leads (alphabetical order)

H. B. Peacock, SRTC

R. L. Sindelar, SRTC

B. J. Wiersma, SRTC

Editors (alphabetical order)

T. M. Adams, SRTC

R. L. Sindelar, SRTC

D. W. Vinson, SRTC

Contributors (alphabetical order)

T. M. Adams, SRTC

G. R. Caskey, Jr., ORISE

J. P. Howell, SRTC

N. C. Iyer, SRTC

P. S. Lam, SRTC

W. S. Large, SFSD

S. Y. Lee, SRTC

M. R. Louthan, Jr., SRTC

J. I. Mickalonis, SRTC

H. B. Peacock, Jr., SRTC

R. L. Sindelar, SRTC

D. W. Vinson, SRTC

B. J. Wiersma, SRTC 


\section{List of Acronyms}

\begin{tabular}{|c|c|}
\hline Acronym & Definition \\
\hline AEA & Atomic Energy Act \\
\hline Al-SNF & Aluminum-clad, Aluminum-based Spent Nuclear Fuel \\
\hline ANL & Argonne National Laboratory \\
\hline ANSU/ANS & American National Standards Institute/American Nuclear Society \\
\hline ASME & American Society of Mechanical Engineers \\
\hline ASTM & American Society for Testing and Materials \\
\hline ATR & Advanced Test Reactor \\
\hline ATP & Alternative Al SNF Treatment Technology Program \\
\hline $\mathrm{BOL}$ & Beginning of Life \\
\hline CAA & Clean Air Act \\
\hline CDA & Controlled Design Assumptions Document \\
\hline CERCLA & Comprehensive Environmental Response, Compensation, and Liability Act \\
\hline CFR & Code of Federal Regulations \\
\hline CPP & Chemical Processing Plant (INEL) \\
\hline $\mathrm{CPP}$ & Cyclic Potentiodynamic Polarization \\
\hline CR & Corrosion Rate \\
\hline CRWMS & Civilian Radioactive Waste Management System \\
\hline DBE & Design Basis Event \\
\hline DHLW & Defense High-Level Waste \\
\hline DIS & Disposability Interface Specification \\
\hline DOE & U.S. Department of Energy \\
\hline DOE-EM & U.S. Department of Energy Office of Environmental Management \\
\hline DOE-RW & $\begin{array}{l}\text { U.S. Department of Energy Office of Civilian Radioactive Waste } \\
\text { Management (also OCRWM) }\end{array}$ \\
\hline DRR & Domestic Research Reactor \\
\hline DWPF & Defense Waste Processing Facility \\
\hline EBDRD & Engineered Barrier Design Requirements Document \\
\hline EBS & Engineered Barrier System \\
\hline EDM & Electro-Discharge Machine \\
\hline EDS & Energy Dispersive Spectrometry \\
\hline EIS & Environmental Impact Statement \\
\hline EOL & End of Life \\
\hline EPA & Environmental Protection Agency \\
\hline $\mathrm{F} \& \mathrm{OR}$ & Functional \& Operating Requirements \\
\hline FFCA & Federal Facilities Compliance Act \\
\hline FRR & Foreign Research Reactor \\
\hline FWPCA & Federal Water Pollution Control Act \\
\hline $\mathrm{GC}$ & Gas Chromatograph \\
\hline HEDL & Hanford Engineering Development Laboratory \\
\hline HEPA & High-Efficiency Particulate Air \\
\hline HEU & Highly-Enriched Uranium $\left(>20 \%{ }^{235} \mathrm{U}\right.$ in $\left.\mathrm{U}\right)$ \\
\hline HFBR & High-Flux Beam Reactor \\
\hline HFIR & High Flux Isotope Reactor \\
\hline HLW & High Level Waste \\
\hline HLWG & High-Level Waste Glass \\
\hline HVAC & Heating, Ventilation, \& Air Conditioning \\
\hline IAEA & International Atomic Energy Agency \\
\hline ICPES & Inductive Coupled Plasma Emission Spectroscopy \\
\hline ID & Inner Diameter \\
\hline IMNM & Interim Management of Nuclear Materials \\
\hline $\begin{array}{l}\text { INEL } \\
\text { IR }\end{array}$ & $\begin{array}{l}\text { Idaho National Engineering Laboratory } \\
\text { Infrared }\end{array}$ \\
\hline
\end{tabular}




\begin{tabular}{|c|c|}
\hline LANL & Los Alamos National Laboratory \\
\hline LEU & Low-Enriched Uranium ( 2 to $20 \%{ }^{235} \mathrm{U}$ in $\mathrm{U}$ ) \\
\hline LLNL & Lawrence Livermore National Laboratory \\
\hline LPP & Linear Potentiodynamic Polarization \\
\hline $\mathrm{MCO}$ & Multi-Canister Overpacks \\
\hline MD & Melt-Dilute \\
\hline MGDS & Mined Geologic Disposal System \\
\hline MIT & Massachusetts Institute of Technology \\
\hline MPC & Multi-Purpose Canister \\
\hline MRS & Monitored Retrievable Storage \\
\hline MTHM & Metric Tons Heavy Metal \\
\hline MTR & Materials Test Reactor \\
\hline MTRE & Materials Test Reactor Equivalent \\
\hline MWd & Megawatt-days \\
\hline NDE & Non-Destructive Examination \\
\hline NEPA & National Environmental Policy Act \\
\hline NRC & U.S. Nuclear Regulatory Commission \\
\hline NWPA & Nuclear Waste Policy Act \\
\hline OCRWM & Office of Civilian Radioactive Waste Management \\
\hline OD & Outer Diameter \\
\hline ORNL & Oak Ridge National Laboratory \\
\hline ORR & Oak Ridge Research Reactor \\
\hline PCT & Product Consistency Tests \\
\hline PEIS & Programmatic Environmental Impact Statement \\
\hline PIN & refers to the SNF with pin geometry \\
\hline PNNL & Pacific Northwest National Laboratory \\
\hline QA & Quality Assurance \\
\hline RBOF & Receiving Basin for Offsite Fuel \\
\hline RCRA & Resource Conservation and Recovery Act \\
\hline $\mathrm{RH}$ & Relative Humidity (vapor pressure of $\mathrm{H}_{2} \mathrm{O}$ /saturation pressure of $\mathrm{H}_{2} \mathrm{O}$ ) \\
\hline RHF & Réacteur à Haut Flux \\
\hline RT & Room Temperature \\
\hline RW & Office of Civilian Radioactive Waste Management \\
\hline SARA & Superfund Amendments and Reauthorization Act \\
\hline SCC & Stress Corrosion Cracking \\
\hline SEM & Scanning Electron Microscope \\
\hline SFSD & Spent Fuel Storage Division \\
\hline SI & Structural Integrity \\
\hline SNF & Spent Nuclear Fuel \\
\hline SRS & Savannah River Site \\
\hline SRTC & Savannah River Technology Center \\
\hline TBD & To Be Determined \\
\hline TBV & To Be Verified \\
\hline TMI & Three Mile Island \\
\hline TRU & Transuranic elements \\
\hline TSF & Treatment and Storage Facility \\
\hline VLEU & Very-Low-Enriched Uranium $\left(<2 \%{ }^{235} \mathrm{U}\right.$ in $\left.\mathrm{U}\right)$ \\
\hline WAC & Waste Acceptance Criteria (presently in the DIS) \\
\hline WP & Waste Package \\
\hline XRD & X-Ray Diffraction \\
\hline YMSCO & Yucca Mountain Site Characterization Office \\
\hline
\end{tabular}




\section{Table of Contents}

1.0 EXECUTIVE SUMMARY

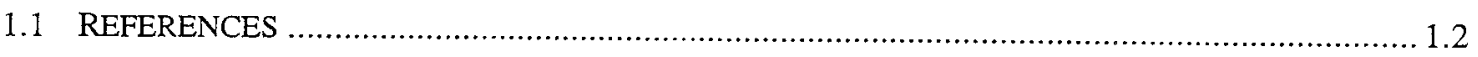

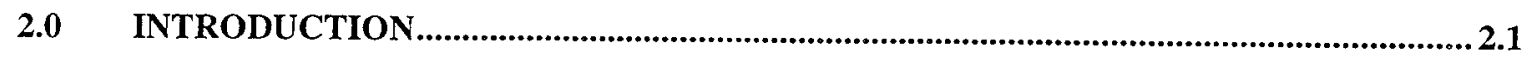

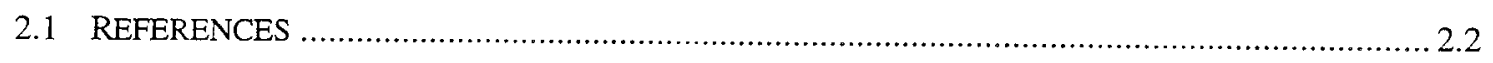

3.0 ALUMINUM-BASED SPENT NUCLEAR FUEL ............................................................

3.1 DOE SNF REPOSITORY PERFORMANCE CATEGORIES ...................................................... 3.1

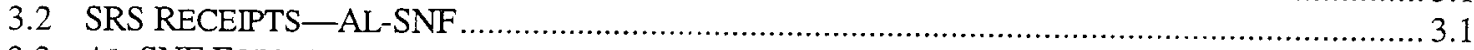

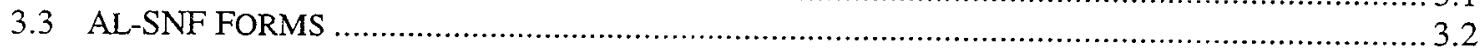

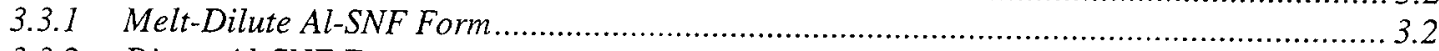

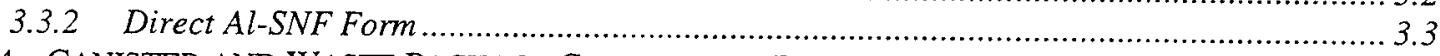

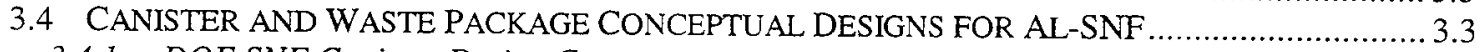

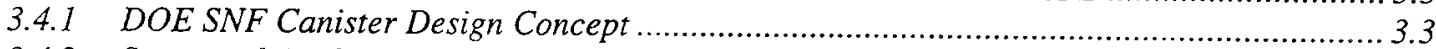

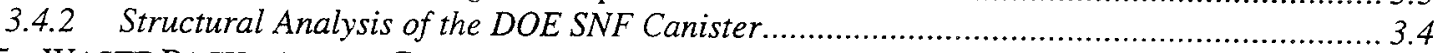

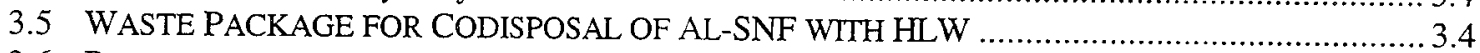

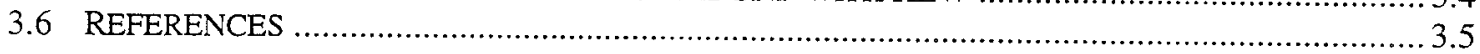

\subsection{ASSESSMENT OF ACCEPTABILITY OF DOE AL-SNF FORMS FOR INTERIM DRY}

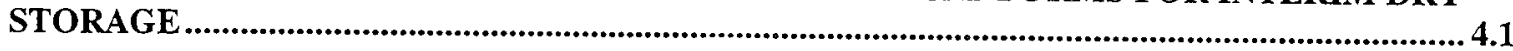

4.1 INTERIM STORAGE OF DOE ALUMINUM-SNF FORMS ................................................... 4.1

4.2 REQUIREMENTS FOR THE AL-SNF FORM FOR ROAD-READY, INTERIM DRY STORAGE …... 4.2

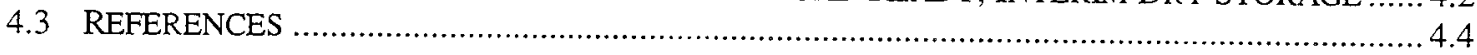

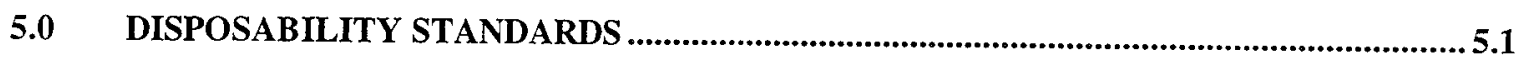

5.1 DISPOSABILITY STANDARDS FOR SNF IN DISPOSABLE CANISTERS .................................... 5.1

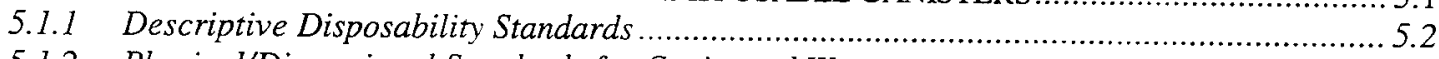

5.1.2 Physical/Dimensional Standards for Canistered Waste ................................................. 5.11

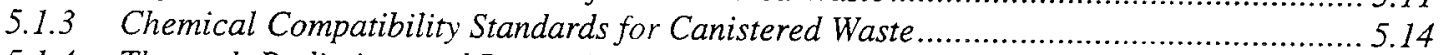

5.1.4 Thermal, Radiation, and Pressurization Standards for Canistered Waste............................ 5.21

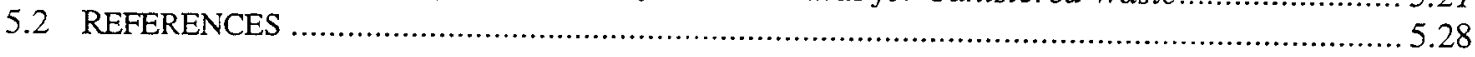

\section{A.0 SCOPE OF FUEL AT SRS TO BE DISPOSITIONED .................................................. 1}

A.1 ALUMINUM-BASED SPENT NUCLEAR FUEL .............................................................

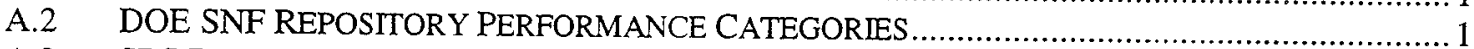

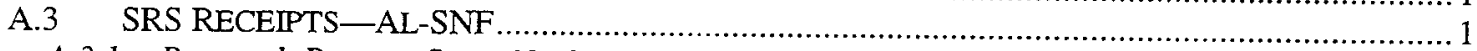

A.3.1 Research Reactor Spent Nuclear Fuel Designs (Al-clad SNF Only) ......................................

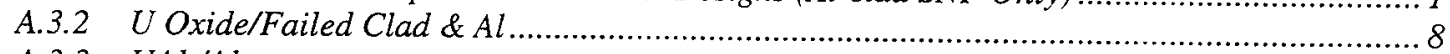

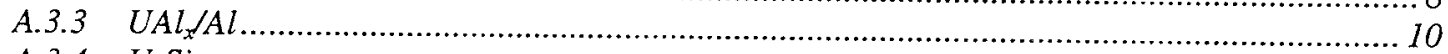

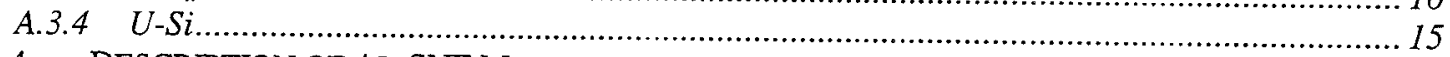

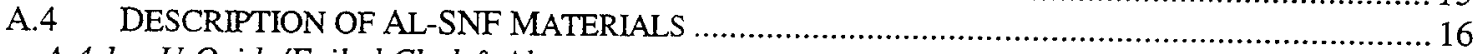

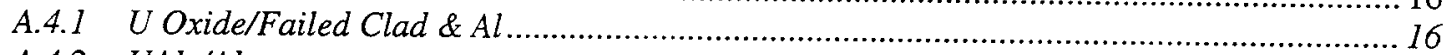

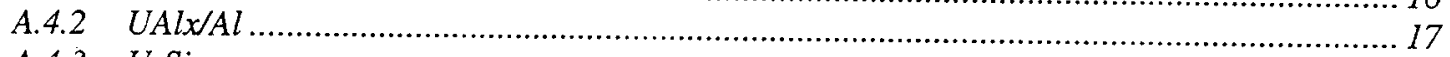

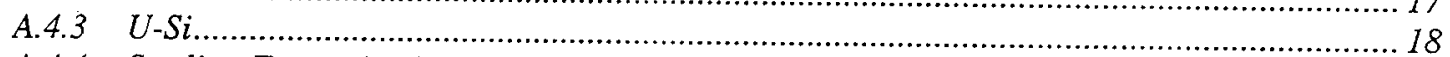

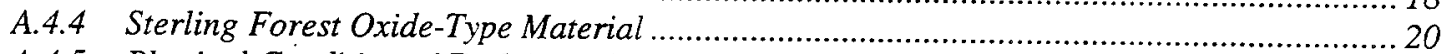

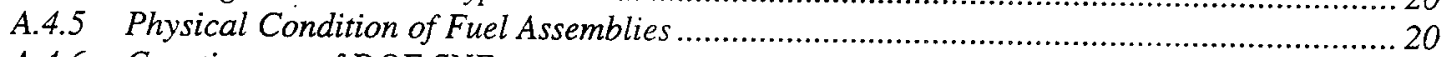

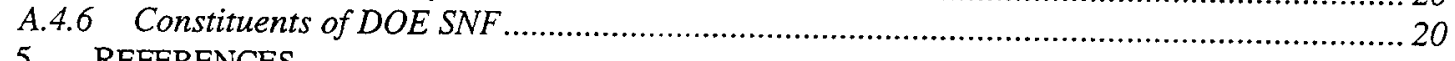

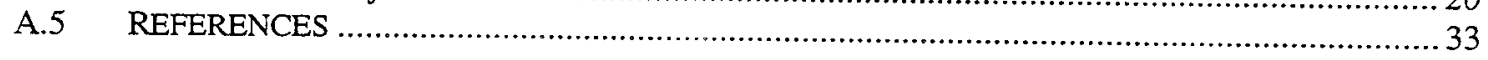




\section{List of Tables}

TABLE 3.1 ESTIMATE OF INVENTORY AND EXPECTED RECEIPTS OF AL-SNF ................................ 3.1

TABLE 5.1 RADIONUCLIDE INVENTORY REQUIREMENTS ….................................................. 5.15

TABLE 5.2 BOUNDING RADIONUCLIDE INVENTORIES PER ELEMENT FOR SELECTED FUEL CATEGORIES (CURIES)

TABLE 5.3 PARAMETERS TO PRECLUDE CRITICALITY FOR THE MELT-DILUTE FORM WITHOUT POISONS

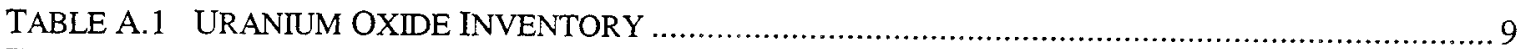

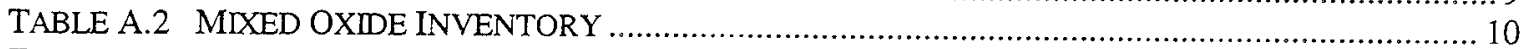

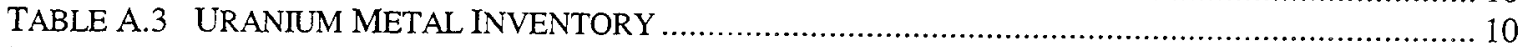

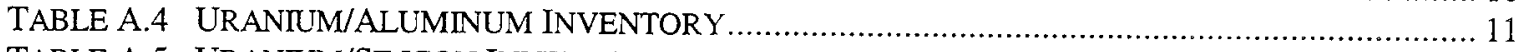

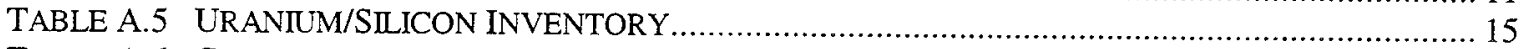

TABLE A.6 COMPOSITIONS OF TYPICAL MTR CLADDING ALLOYS MANUFACTURED BY

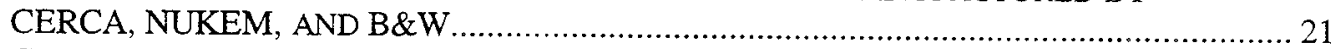

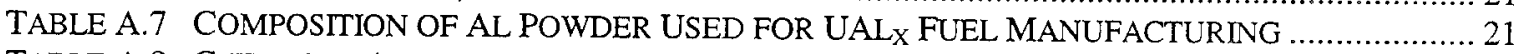

TABLE A.8 CHEMICAL ANALYSIS OF THE DEPLETED URANIUM FOR DILUTION ….......................... 21

TABLE A.9 BOUNDING ESTIMATES OF MASS OF FISSION PRODUCTS, ACTINIDES, AND LIGHT

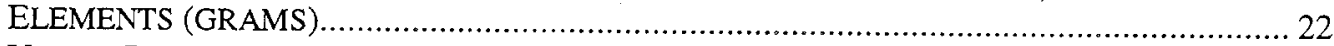

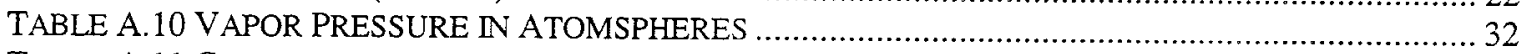

TABLE A.11 COMPOUNDS AND ALLOYS OF VARIOUS OFFGAS SPECIES WITH URANIUM AND 


\section{List of Figures}

FIGURE 3.1 TOTAL WASTE VOLUME FOR FRR, DRR, HFIR, AND ATR FUEL ASSEMBLIES AS A FUNCTION OF THE DILUTION FACTOR, PROCESS ADDITIONS AND WASTE COMPOSITION

FIGURE 3.2 CODISPOSAL CONCEPTUAL CONFIGURATION.

FIGURE 5.1 THERMAL MODELING OF CODISPOSAL SNF WASTE PACKAGE IN A GEOLOGICAL REPOSITORY

FIGURE 5.2 HE-COOLED 75\% VOLUME MELT-DILUTE CO-DISPOSAL WP TEMPERATURE DISTRIBUTION FOR VARIOUS STORAGE TIMES BASED ON THE BASELINE MODEL ..... 5.24

FIGURE 5.3 HE-COOLED DIRECT CO-DISPOSAL WP TEMPERATURE DISTRIBUTION FOR VARIOUS STORAGE TIMES BASED ON BASELINE MODEL WITH BOUNDING SNF DECAY HEAT SOURCE.

FIGURE 5.4 COMPARISON OF CENTERLINE TEMPERATURE DISTRIBUTIONS BASED ON THE BASELINE MODEL AND THE DETAILED MODEL FOR HELIUM-COOLED DIRECT CODISPOSAL WP WTTH BOUNDING DECAY HEAT SOURCE.

FIGURE A.1 TYPICAL (BOXED-TYPE/FLAT-PLATE) ALUMINUM-BASED FUEL ELEMENT SCHEMATIC 2

FIGURE A.2 TYPICAL (BOXED-TYPE/CURVED-PLATE) ALUMINUM-BASED FUEL ELEMENT SCHEMATIC

FIGURE A.3 TYPICAL MTR (TUBE-TYPE) ALUMINUM-BASED FUEL ELEMENT SCHEMATIC ................5

FIGURE A.4 TYPICAL PIN-TYPE (ALUMINUM-BASED) FUEL ELEMENT SCHEMATIC ........................... 6

FIGURE A.5 TYPICAL INVOLUTE(1)-TYPE (ALUMINUM-BASED) FUEL ELEMENT SCHEMATIC …….... 7

FIGURE A.6 TYPICAL INVOLUTE(2)-TYPE (ALUMINUM-BASED) FUEL ELEMENT SCHEMATIC .......... 8

FIGURE A.7 HIGH BURNUP U $\mathrm{U}_{3} \mathrm{O}_{8}$-AL FUEL IRRADIATED IN RESEARCH AND TEST REACTORS .......... 17

FIGURE A.8 BNARY PHASE DIAGRAM OF THE URANIUM-ALUMINUM SYSTEM …........................... 17

FIGURE A.9 HIGH BURNUP UAL ${ }_{X}$-AL FUEL IRRADIATED IN RESEARCH AND TEST REACTORS .......... 18

FIGURE A.10 HIGH BURNUP $\mathrm{U}_{3} \mathrm{SI}_{2}$-AL FUEL IRRADIATED IN RESEARCH AND TEST REACTORS .... 19

FIGURE A.11 TERNARY ISOTHERMAL SECTION FROM THE U-AL-SI SYSTEM AT 950 C ............... 19 


\subsection{EXECUTIVE SUMMARY}

Two technologies, melt-dilute and direct disposal, are being developed for treatment and packaging of aluminum-clad, aluminum-based spent nuclear fuel (AI-SNF) assemblies for interim dry storage and ultimate disposal. Direct disposal entails placement of intact fuel assemblies within baskets in a DOE spent nuclear fuel disposable canister. In the Melt-Dilute option, fuel assemblies would be melted, diluted with depleted uranium and the resulting ingots placed in a disposable canister. In both cases, codisposal of the canistered Al-SNF form in a waste package (WP) with vitrified high level waste (HLW) in the Mined Geologic Disposal System (MGDS) has been proposed.

Preparation and treatment of the Al-SNF and interim dry storage of the resulting Al-SNF forms in disposable canisters, road-ready for shipment to the MGDS, would take place in a Treatment and Storage Facility (TSF) at the Savannah River Site (SRS).

This report provides a technical assessment of the Melt-Dilute and Direct Al-SNF forms in disposable canisters with respect to meeting the requirements for disposal in the MGDS and for interim dry storage in the TSF at SRS. Requirements that apply to disposal of SNF owned by the Department of Energy (DOE) in the MGDS are contained in Section 4, Draft Standards for Spent Nuclear Fuel in Disposable Canisters, of the Mined Geologic Disposal System Draft Disposability Interface Specifications dated February 1998 [1]. The "draft" standards and the current canister and waste package designs are based on MGDS designs and operational concepts as of September 1997 and are subject to revision until such time as the Nuclear Regulatory Commission (NRC) issues a construction permit for the MGDS. Requirements for Road-Ready Interim Dry Storage at SRS have been established to enable full, safe retrievability from time of receipt throughout treatment and storage and were derived from regulatory and site-specific criteria [2].

The technical assessment is based on results of several analytical and experimental investigations at SRS, criticality calculations of the Direct form performed by the Office of Civilian Radioactive Waste Management (OCRWM) of the Department of Energy (DOE) [3, 4], and criticality calculations for the Melt-Dilute form by the Westinghouse Safety Management Solutions [5].

Both Melt-Dilute and Direct forms in disposable canisters can meet the requirements of the Draft Standards for Spent Nuclear Fuel in Disposable Canisters. Completed analyses indicate that the Melt-Dilute form of eutectic composition $\left(13.2 \% \mathrm{U}\right.$ ) and containing less than $20 \%{ }^{235} \mathrm{U}$ meets the requirements of the draft standards. Additional criticality analysis of the Melt-Dilute form and HLW degraded within a waste package are needed for the disposability assessment and are being scheduled for FY99. The Melt-Dilute form is flexible in that additional dilution or the addition of neutron poisons to the Melt-dilute product can be readily made, if necessary.

The Direct form in disposable canisters can meet all requirements of the Draft Standards. Criticality analyses have identified that neutron poison additions are needed to preclude criticality of degraded Al-SNF within a canister and of degraded Al-SNF and HLW within a waste package. A method is needed to incorporate neutron poisons into the canisters in the demonstration that the reactivity of all possible configurations is within the acceptable limit. Several poison materials have been suggested and are being evaluated and tested for compatibility with the Al-SNF. These activities will continue throughout FY99.

The requirements for disposal in the MGDS are subject to change up to and throughout the licensing phase of the repository. Qualification of the Al-SNF forms for repository disposal will involve validation testing and confirmed analyses to demonstrate the latest requirements are met for the proposed waste package/DOE SNF canister/Al-SNF form design. Qualified methods for non- 
destructive analysis to determine the content of radioisotopes of the Direct form may be needed to provide data at a higher confidence than that from existing records. These methods are yet to be developed.

\subsection{References}

$1 \quad$ M. S. Abashian, "Mined Geologic Disposal System Draft Disposability Interface Specification," DI Number B00000000-0171704600-00108 REV 00. Civilian Radioactive Waste Management System Management \& Operating Contractor (draft February 1998).

2 WSRC-TR-95-0347, "Acceptance Criteria for Interim Dry Storage of Aluminum-Alloy Clad Spent Nuclear Fuels (U)," Westinghouse Savannah River Co., March 1996.

3 A. H. Wells and J. W. Davis. Evaluation of Codisposal Viability for Aluminum-Clad DOEOwned Spent Fuel: Phase 1; Intact Codisposal Canister. DI Number BBA000000-017175705-00011 REV 00, Civilian Radioactive Waste Management System Management \& Operating Contractor (June 9, 1997).

4 J. W. Davis and P. Gottlieb. Evaluation of Codisposal Viability for Aluminum-Clad DOEOwned Spent Fuel: Phase 2; Degraded Codisposal Waste Package Internal Criticality. DI Number BBA000000-01717-5705-00017 REV 00, Civilian Radioactive Waste Management System Management \& Operating Contractor (December 15, 1997).

5 WSMS-CRT-98-0003 Rev. 0, "Criticality Analysis of DOE SNF Codisposal Canister with Melt and Dilute MTR Fuel," S. M. Revolinski. Westinghouse Safety Management Solutions, February 27, 1998. 


\subsection{INTRODUCTION}

Through the Environmental Impact Statement (EIS) process [1,2,3], the United States Department of Energy (DOE) has selected the Savannah River Site (SRS) as the location to consolidate aluminum-clad, aluminum-based spent nuclear fuel (Al-SNF) from foreign and domestic research reactors (FRR and DRR, respectively). These SNF are either in service, being stored in water basins or in dry storage casks at the reactor sites, or have been transferred to SRS and are presently being stored in water basins. Prolonged underwater storage is not desirable because of the cost of operating and maintaining a properly controlled water system and the limited space and handling capabilities available at most research reactor facilities. Consequently, a strategy involving interim dry storage followed by ultimate disposal in a geologic repository is being pursued. A majority of this inventory contains highly enriched uranium (HEU), defined as uranium at greater than $20 \%{ }^{235} \mathrm{U}$. Appendix A contains the inventory of the FRR/DRR Al-SNF that is presently at or will be received at SRS.

The Research Reactor Spent Nuclear Fuel Task Team was appointed by the Office of Spent Fuel Management of DOE to evaluate the effectiveness, relative merits, costs, and difficulties in implementation of alternative technologies and SNF forms for the treatment, packaging, and disposal of Al-SNF [4]. The base case for comparison of the several technologies was chemical reprocessing followed by incorporation into borosilicate glass. The principal recommendations of the Task Team were:

- parallel development of direct disposal and dilution technology options including codisposal with HLW borosilicate glass logs. Codisposal appears possible in both cases;

- utilization of the SRS canyons for chemical reprocessing of SRS fuel, failed or sectioned fuel, and other selected fuel;

- electrometallurgical treatment as an advanced technology backup to direct and dilution technologies;

- DOE-NRC agreement on requirements for SNF disposal and SNF form for HEU; and

- plan, fund, and design a dry storage facility at SRS.

None of the alternative SNF forms, other than borosilicate glass resulting from reprocessing, are qualified for disposal in the federal repository in Yucca Mountain. The SRS Aluminum Spent Nuclear Fuel Alternate Treatment Technology Program (ATP) was initiated to develop technology for the non-reprocessing alternatives which entails treatment and storage of the Al-SNF in a roadready package that meets the requirements for disposal in the Mined Geologic Disposal System (MGDS). Receipt, treatment, storage, and packaging of the Al-SNF are expected to continue over the next four decades and extend beyond the shutdown of the reprocessing facilities at SRS.

Development and licensing of the facilities of the MGDS or the federal repository for ultimate disposal of commercial SNF, defense high level waste (DHLW), and DOE-owned SNF is the responsibility of the Office of Civilian Radioactive Waste Management (OCRWM) of DOE. The present schedule calls for a licensing application for the disposal of these SNF forms in the proposed repository at Yucca Mountain to be submitted by 2002. The licensing application drives the schedule for the repository Performance Assessment and the Viability Assessment to be completed during the 1998 - 2002 period. In order to ensure that DOE-owned SNF, including the Al-SNF, is part of the DOE-RW licensing application, the ATP, a technology development program aimed at evaluating non-processing alternatives for Al-SNF, was initiated in FY97. The functions of the technical programs of the ATP are to develop the treatment processes, perform engineering analyses, and develop the scientific bases necessary to ensure qualification of an 
appropriate AI-SNF form for the repository. The ATP also directs the project for a facility to treat and store the AI-SNF forms. The two candidate forms being developed for a proposed Treatment and Storage Facility (TSF) are the Direct form (intact Al-SNF assemblies) and the Melt-dilute form. These Al-SNF forms are assessed against the waste form requirements for the federal repository.

The Mined Geologic Disposal System Disposability Interface Specification (DIS) provides a list of waste properties and documentation that must be met in order for wastes to be accepted into the Civilian Radioactive Waste Management System Mined Geologic Disposal System [5]. Section 4 of the DIS, Standards for Spent Fuel in Disposable Canisters directly applies to Boiling Water Reactor (BWR) assemblies, Pressurized Water Reactor (PWR) assemblies, and DOE-owned SNF. Section 4 covers both fuel bearing and non-fuel bearing components of SNF including debris and corrosion products from the SNF. Section 8 of the DIS defines data packages to be submitted to the Yucca Mountain Site Characterization Office (YMSCO) of DOE, provides quality assurance and documentation requirements, describes the "acceptability" certification process, and reviews provisions for DOE verification of items in data packages. Section 8 and documentation requirements to certify compliance with the standards in Section 4 are currently incomplete. Furthermore, several of the Disposability Standards require verification or additional work is in progress to support a more specific disposability standard. Section 7 of the DIS, Draft Acceptability Standards for Loaded Casks and Carriers, applies to shipment of the canisters from the host site to the MGDS to assure compatibility with MGDS Surface Facilities, but has no direct impact on waste disposability and is not part of the present discussion.

The subsequent sections of this report describe the Melt-Dilute and Direct Al-SNF forms, the proposed designs for a disposable canister and the waste package, assess the acceptability of the DOE-owned SNF for interim dry storage at SRS, and assess the Al-SNF forms with respect to meeting the draft Disposability Standards for the MGDS. The road-ready packages must also meet U.S. Department of Transportation (DOT) and NRC regulations that govern shipment of nuclear materials as provided in 10 CFR 71. Modeling of the long-term behavior of the Al-SNF forms is part of a performance assessment (PA) of the repository conducted by OCRWM to ensure compliance with NRC radionuclide release limits (10 CFR 60) and as yet-to-be-established EPA dose and possibly ground water standards. Shipment and PA requirements have been incorporated into the Disposability Standards and are not discussed directly in this report.

\subsection{References}

1 Final Environmental Impact Statement, Interim Management of Nuclear Materials. DOE (U.S. Department of Energy), DOE-EIS-0220, Savannah River Operations Office, Aiken, South Carolina (1995).

2 Final Environmental Impact Statement, Proposed Nuclear Weapons Non-Proliferation Policy Concerning Foreign Research Reactor Spent Nuclear Fuel. DOE (U.S. Department of Energy), DOE/EIS-0218F, Assistant Secretary for Environmental Management, Washington, DC (1995).

3 DOE-Owned Spent Nuclear Fuel Technology Integration Plan. DOE/SNF/PP-002, Rev. 1, Idaho National Engineering Laboratory (May 1996).

4 "Technical Strategy for the Treatment, Packaging, and Disposal of Aluminum-Based Spent Nuclear Fuel", Volume 1 of the Research Reactor Spent Nuclear Fuel Task Team Report. prepared for the Department of Energy - Office of Spent Fuel Management (May 1996). 
5 M. S. Abashian, "Mined Geologic Disposal System Draft Disposability Interface Specification," DI Number B00000000-0171704600-00108 REV 00. Civilian Radioactive Waste Management System Management \& Operating Contractor (draft February 1998). 


\subsection{ALUMINUM-BASED SPENT NUCLEAR FUEL}

Aluminum-based spent nuclear fuel (Al-SNF) from research reactors will account for less than $1 \%$ of the total volume of SNF and high level waste that will require disposal in a geologic repository. However, much of the Al-SNF contains HEU with up to $93+\%$ initial enrichment. The Materials Test Reactor (MTR) design assembly which is comprised of fuel elements or plates of aluminumclad, aluminum-uranium alloy fuel is the dominant design (approximately $80 \%$ of total) and fuel material for research reactors. There are limited numbers of tubular, pin, and involute type fuel element designs. Other aluminum-based fuel materials are aluminum-uranium silicide or aluminum-uranium oxide materials. The fuel elements are clad with one of the aluminum alloys 1100,5052 , or 6061 or their foreign equivalents.

\subsection{DOE SNF Repository Performance Categories}

The DOE has categorized all of its spent fuel into sixteen categories. These categories were developed based upon fuel composition and characteristics [1]. The primary concern with grouping the spent fuels was assigning every fuel to a category and making certain that all of the spent fuel fit into a category. The total amount of DOE SNF, excepting Sodium bonded spent fuel (Category 14) and Navy spent fuel (Category 15), is approximately 2436 MTHM. This fuel (Categories 1-13) will be distributed among INEEL, Savannah River, and Hanford. Savannah River has responsibility for a total of 24.03 MTHM that includes fuel from Categories 5-7. Savannah River has 3.67 of the 87.93 MTHM comprising Category 5 and all of the fuels in Categories 6 and 7, 8.96 MTHM and 11.40 MTHM, respectively.

\subsection{SRS Receipts-AI-SNF}

Fuel designs for research reactors are organized into three broad types: (1) materials and test reactor (MTR)-type design, which includes plate-type designs and concentric tube-type designs; (2) pin-type design; (3) involute-type design. An inventory of FRR and DRR SNF for disposition by SRS and the characteristics of each type of fuel are provided in Appendix A. The total number of fuel assemblies in inventory at SRS and expected to be received is shown in Table 3.1. Appendix A contains the specific inventory of the FRR/DRR Al-SNF that is presently at or will be received at SRS.

Table 3.1 Estimate of Inventory and Expected Receipts of AI-SNF

\begin{tabular}{|l|c|c|c|}
\hline & $\begin{array}{c}\text { Mass } \\
(\text { MTHM) }\end{array}$ & $\begin{array}{c}\text { Volume } \\
\left(\mathrm{m}^{3}\right)\end{array}$ & $\begin{array}{c}\text { MTRE } \\
\text { (Note 1) }\end{array}$ \\
\hline Inventory (end 1995) & 0.44 & 8.2 & 1230 \\
Domestic Research Reactors & 7.5 & 128 & 9194 \\
Foreign Research Reactors & 13.4 & 94 & 15000 \\
Transfer from INEEL & 2.5 & 36.2 & 6986 \\
$\quad$ Total (Note 2) & 23.84 & 266.4 & 32410 \\
\hline
\end{tabular}

Note 1 Materials Test Reactor Equivalent (MTRE) fuel assemblies

Note 2 Complied from Reference 2 


\subsection{Al-SNF Forms}

\subsubsection{Melt-Dilute Al-SNF Form}

The current recommended melt-dilute process produces an alloy of eutectic composition, $13.2 \mathrm{wt} \%$ uranium, with an isotopic dilution to $<20 \%{ }^{235} \mathrm{U}$. There are several uranium compositions that can be cast for the uranium-aluminum system, but for the melt-dilute process, a specific alloy content or an adjusted composition is desired for the SNF form. This simplifies both the production process and qualification of the SNF form for the geologic repository. The composition selected for the process basically depends on the isotopic dilution required for the spent nuclear fuel form and the waste volume criteria for repository storage. Three basic isotopic dilutions have been investigated $-20 \%, 5 \%$, and $2 \%$. Each dilution can be achieved by either adding depleted uranium metal or by adding both depleted uranium and aluminum metal to the molten alloy. The process used for treatment affects the waste volume as indicated in Figure 3.1 where the waste volume is shown as a function of the dilution factor (\%) for aluminum-base SNF. Advantages of a $20 \%$ isotopic dilution and the eutectic composition include: (1) lower process operating temperatures, (2) minimum gravity segregation in the casting, (3) lower volume of off-gas products and (4) lower associated costs. When compared to other dilution methods, the $20 \%$ isotopic dilution offers the greatest versatility because SNF forms containing about 5 to $67 \mathrm{wt} \%$ uranium can be produced and stored in less than 400 canisters each. If the SNF form is diluted to approximately $20 \%{ }^{235} \mathrm{U}$ or less, criticality and proliferation concerns are reduced or may be eliminated for geologic repository disposal.

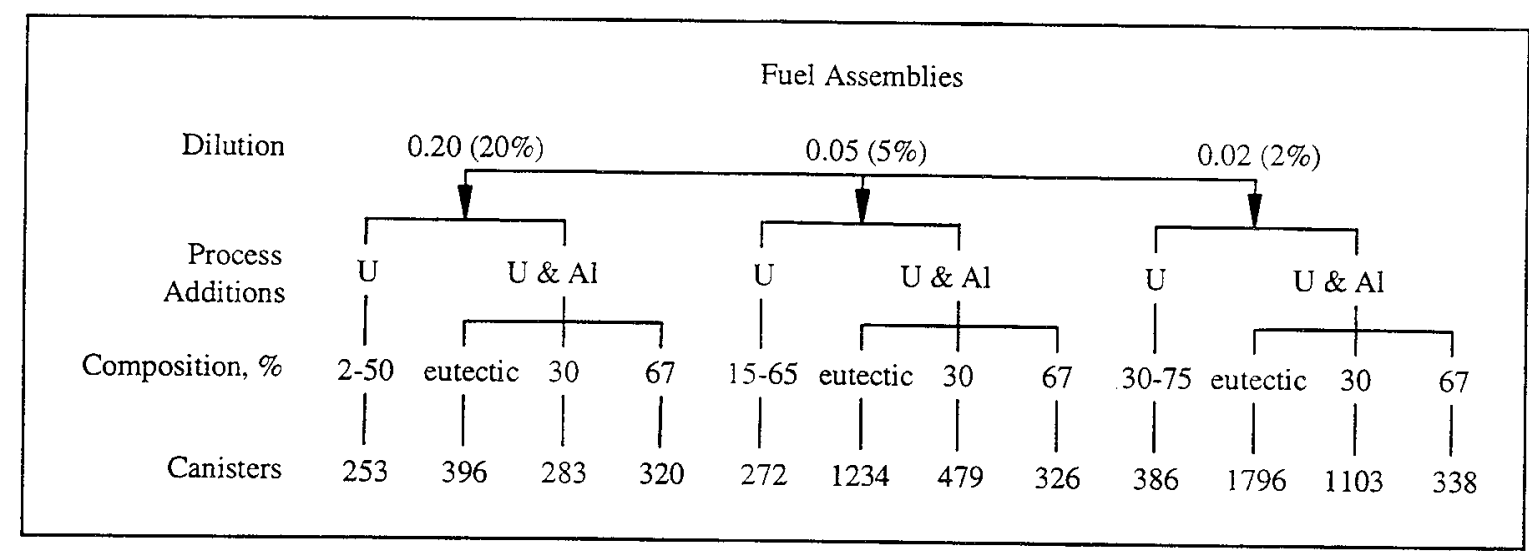

Figure 3.1 Total Waste Volume for FRR, DRR, HFIR, and ATR Fuel Assemblies as a Function of the Dilution Factor, Process Additions and Waste Composition [3].

Solidification of the eutectic composition produces a uniform microstructure with little or no gravity segregation of the aluminum-uranium intermetallic phase. During melting of the silicide and oxide type fuels, reaction between the molten aluminum and the uranium silicon or uranium oxygen compounds produces aluminum-uranium intermetallic compounds and the resulting alloy is comparable to the aluminum uranium alloys. The crucible for the melt-dilute treatment would accommodate 15-20 MTR type elements or their equivalent and yield an ingot that would fit into the canister. The loading of fissile mass for a canister containing the recommended melt-dilute composition and dilution is $22 \mathrm{Kg}^{235} \mathrm{U}$. 


\subsubsection{Direct Al-SNF Form}

In direct disposal, the fuel assemblies would be packaged in a disposable canister without modification other than the possible removal of the end fittings. Baskets and separators would hold the fuel assemblies in position within the canister. The majority of fuel assemblies are the MTR design with square (ORR), rectangular, or trapezoidal (MIT) cross sections. Small quantities of tubular, pin, or involute type fuel assemblies have been irradiated. Preliminary designs have been made for the baskets and separators to accommodate fuel assemblies with square and trapezoidal cross sections, but designs have not been proposed for the other fuel assembly designs.

\subsection{Canister and Waste Package Conceptual Designs for AI-SNF}

The Direct and Melt-Dilute forms of Al-SNF would be loaded into a DOE SNF canister for codisposal with five glass logs of vitrified HLW in the repository waste package (WP). The canister would be a disposable canister so that repackaging of the Al-SNF would not be required at the MGDS. The DOE SNF canister has not been designed and analyzed although concepts for the canister are being developed through a working group of the national program. The controls and requirements for the DOE SNF are being developed in the Interface Control Document [4].

\subsubsection{DOE SNF Canister Design Concept}

A conceptual design has been proposed for a disposable canister that is compatible with codisposal of DOE-owned Al-SNF with HLW. Canister characteristics are:

Outside diameter

Wall thickness

Overall length

Primary material of construction

Empty canister weight
17.3 inches $(439.3 \mathrm{~mm})$

0.59 inches $(15 \mathrm{~mm})$

117.9 inches $(409.3 \mathrm{~mm})$

XM-19 stainless steel (Nitronic-50)

1459 pounds

The canister does not require internal basket and separator structures for the Melt-Dilute option as the SNF form consists of solid ingots of diluted SNF. The total loaded mass for a canister and three ingots of $13.2 \mathrm{wt} \%$ uranium at $20 \%{ }^{235} \mathrm{U}$ is estimated as 3786 pounds [5].

\section{Typical Loaded Canister Weight}

Empty canister shell with lids

Three melt-dilute forms

Total
1459 pounds

2327 pounds

3786 pounds

For the Direct disposal option, each canister can accommodate 40 nominal MTR (ORR) type assemblies or 64 MIT type assemblies. Loaded canister weights have been estimated for direct disposal of the MTR and MIT type SNF only. In both cases internal basket and separator structures are required.

\section{Canister Internals-MTR Assemblies}

Basket and separator material

Basket diameter

Basket length

Basket wall thickness

Basket capacity

Basket and separator weight
Type $316 \mathrm{~L}$ borated stainless steel $\sim 16.0$ inches $(409 \mathrm{~mm})$

26 inches $(660.4 \mathrm{~mm})$

$\sim 0.2$ inches $(5 \mathrm{~mm}$ )

10 nominal MTR assemblies

232 pounds 


\begin{tabular}{lrl}
\multicolumn{2}{c}{ Typical Loaded Canister Weight-MTR Assemblies } \\
Empty canister shell with lids & 1459 & pounds \\
Four baskets & 930 & pounds \\
40 MTR assemblies & 478 & pounds \\
Total & 2867 & pounds
\end{tabular}

The proposed basket design for rhomboidal MIT assemblies has not been carried out in detail, but would hold 16 assemblies. Each canister could accommodate four baskets. This basket design is uncertain, however, as there are relatively few MIT assemblies to be disposed of. Presently there are 72 MIT assemblies at SRS and the expected receipt rate is 10 assemblies per year. Three codisposal canisters with rhomboidal baskets would hold the present inventory and expected receipts for the next 12 years. A simpler could be designed which would hold fewer assemblies and decrease the canister weight.

\begin{tabular}{lrl}
\multicolumn{3}{c}{ Typical Loaded Canister Weight-MIT Assemblies } \\
Empty canister shell with lids & 1459 & pounds \\
Four baskets & 1171 & pounds \\
64 MIT assemblies & 376 & pounds \\
Total & 3006 pounds
\end{tabular}

Canister design and material specification are subject to revision as repository requirements evolve.

\subsubsection{Structural Analysis of the DOE SNF Canister}

Several structural analyses of the DOE SNF disposable canister have been performed [4,6]. These analyses focussed on drop accidents as the most severe accidents. Evaluation of all Design Basis Events (DBE) is continuing. Canister degradation as a result of interim storage of SNF forms and through the pre-closure period has not yet been formally addressed in these analyses. The controls placed on drying Al-SNF and on storage temperature for Al-SNF (see section 4 of this report) should not lead to canister degradation during interim dry storage. Likewise, the environmental conditions to which the canister will be exposed throughout the pre-closure period in the repository should not lead to significant canister degradation.

\subsection{Waste Package for Codisposal of Al-SNF with HLW}

The proposed codisposal waste package design would accommodate one DOE SNF canister of AlSNF at the center of the package surrounded by five canisters of vitrified HLW, Figure 3.2. The repository waste package as currently envisioned [1] has an outer diameter of 75 -inches and a length of 10 feet. There is an inner wall made of a corrosion resistant material that is $2 \mathrm{~cm}$ thick, such as Alloy 625 or C-22. The outer wall is a corrosion allowance material of carbon steel (A516) that is $5 \mathrm{~cm}$ thick. The SNF canister would be placed at the center of the waste package and be surrounded by five equally spaced canisters of vitrified HLW. Material for the HLW canister is a low carbon austenitic stainless steel such as Type 304L. Both the canisters and the waste package would be back filled with helium. 


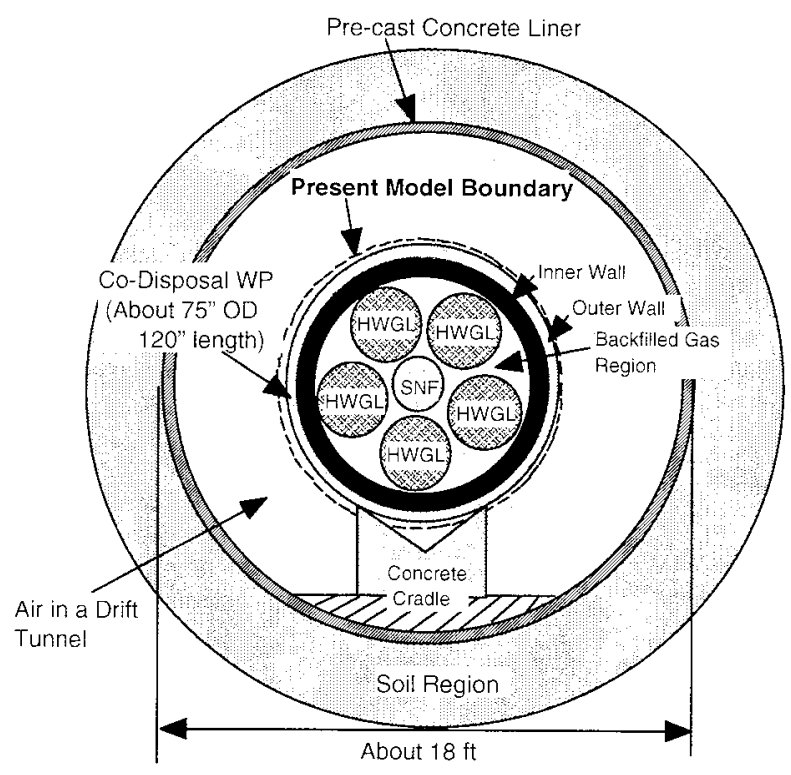

Figure 3.1 Conceptual Configuration for Codisposal in the MGDS

\subsection{References}

1 J. O. Duguid, J. A. McNeish, V. Vallikat, D. Cresap, and N. J. Erb, "Total System Performance Assessment Sensitivity Studies of U. S. Department of Energy Spent Nuclear Fuel," Civilian Radioactive Waste Management System, Management and Operating Contractor, DI Number A00000000-01717-5705-00017, REV 01 (September 30, 1997).

2 Savannah River Site Spent Nuclear Fuel Near-Term Management Plan, USDOE (July 1997).

3 A. Brewer. "Spent Nuclear Fuel Estimated Quantity of Disposal Canisters", WSRC Calculation Sheet G-CLC-C-0001 (June 1997).

4 Interface Control Document for U. S. Department of Energy Spent Nuclear Fuel to the Mined Geologic Disposal System for Mechanical and Envelope Interfaces Between the Department of Energy Offices of Environmental Management and Civilian Radioactive Waste Management, DI Number A000000000-01717-8100-000007, Rev 00 (December 17, 1997).

5 SFS-FID-98046, "Characteristics of SNF Disposal Canisters," W. S. Large, April 1998.

6 "Evaluation of Codisoposal Viability for Aluminum-Clad DOE-Owned Spent Fuel: Phase I Intact Codisposal Canister," Civilian Radioactive Waste Management System, Management and Operating Contractor, DI Number BBA000000-01717-5705-00011, REV 00 (June 9, 1997). 


\subsection{ASSESSMENT OF ACCEPTABILITY OF DOE AL-SNF FORMS FOR INTERIM DRY STORAGE}

The envisioned path for ultimate disposition of the aluminum-based spent nuclear fuel assemblies involves transfer and treatment of wet-stored assemblies into an Al-SNF form (direct or meltdiluted) in a sealed canister. The canisters would be in interim dry storage for up to 40 years, awaiting repository disposal. The canisters would be transported to the repository and placed into waste packages for ultimate disposal. To proceed on this path, the Al-SNF form must meet requirements for both the interim dry storage system and the Mined Geologic Disposal System.

Section 4.1 provides an overview of the treatment of the Al-SNF assemblies and storing Al-SNF forms at SRS. Section 4.2 provides the requirements for interim dry storage of Al-SNF forms. Included are the sources from which these requirements are derived and the technical bases. Both the Melt-Dilute and the Direct Al-SNF forms can be dried and treated to meet the requirements in Section 4.2 .

\subsection{Interim Storage of DOE Aluminum-SNF Forms}

A preconceptual design of a facility to Transfer, Storage, and Shipment facility, currently in the pre-conceptual design phase, at SRS [1] will provide for treatment of as-received Al-SNF assemblies, e.g., wet-stored fuel. This facility will produce an Al-SNF form that can be qualified for geologic repository storage. Interim dry storage will be provided at the TSF facility until the canisters are transferred to the geologic repository. The storage in this configuration is termed "road-ready." The intended design life for systems to store the road-ready Al-SNF forms is 40 years [1]. Recently, functional performance requirements (FPRs) for a Treatment and Storage Facility (TSF) [2] with technical bases [3] have been prepared.

The total number of fuel assemblies in inventory at SRS and expected to be received is shown in Table 3.1. The enriched uranium contents and the burnup achieved by these fuels cover wide ranges (see Appendix A). The expected average receipt rate of these assemblies, 394 MTR Equivalent assemblies and $4 \mathrm{HFIR} / \mathrm{RHF}$ assemblies per month [4], has been incorporated into the pre-conceptual design requirements of the TSF [1].

The design and construction of the TSF shall meet the established requirements necessary for licensing by NRC as an interim dry storage facility [5-6]. Provisions in the Standard Guide for extended service of interim dry storage facilities [7] will also be considered in the design for a 40year life. The Al-SNF forms in their canisters shall also meet requirements for the MGDS so that the DOE can obtain a license from the NRC for the geologic repository, which includes these forms. These requirements are discussed in Section 5 of this report.

Definitions important to the intended receiving, handling, treatment, storage, and disposal of spent nuclear fuel are contained in Section 2.1.2 of Reference 1. The following definitions are added for clarification:

DOE Aluminum-based Spent Nuclear Fuel (AI-SNF) - Nuclear fuels under the jurisdiction of the U. S. Department of Energy that have been exposed in a nuclear reactor whose fuel material is characterized as uranium compounds in an aluminum matrix and whose cladding is an aluminum alloy. 
Road-Ready - The term used to indicate that the Al-SNF form is in a DOE SNF canister, ready for transfer to and placement in the waste package of the MGDS. The term "disposable canister" is also used in the DOE-RW DIS [8].

DOE Al-SNF form - The material from the Al-SNF assemblies to be disposed of in the repository. Two candidate forms are proposed for Al-SNF. These are the direct fuel assembly form (Direct Form) and the treated form (Melt-Dilute Form).

The TSF facility will treat the Al-SNF form to create a "road-ready" package and will provide for storage. That is, the SNF will be canistered and interim dry-stored at the TSF facility without the need for further treatment until transfer of the SNF canisters to the federal repository is authorized. Statistical sampling of the canisters is envisioned as sufficient to ensure canister integrity and to verify compliance with storage criteria prior to transportation to the geologic repository.

\subsection{Requirements for the Al-SNF Form for Road-Ready, Interim Dry Storage}

The TSF facility at SRS will be designed and operated in compliance with a NRC license. The AlSNF form and the interim dry storage system shall be in compliance with the requirements of this section. These requirements are derived from 10 CFR 72, applicable standards, and site-specific criteria and other requirements $[1,5-7 ; 9,10,11]$. These requirements are based on the fundamental requirement that the Al-SNF form (e.g. direct Al-SNF or melt-dilute SNF) be maintained in a condition that enables full, safe retrievability from time of receipt throughout treatment and storage. That is, the limits to the treatment and storage conditions provide for preventing excessive fuel degradation and unsafe conditions throughout the interim dry storage period. Testing is being performed to validate the technical bases for the requirements (see Section 4.1) and therefore the requirements may be revised in the future. These requirements are being codified to be included as an appendix to the ASTM standard guide for extended interim dry storage [7] and thereby receive national consensus.

Up to approximately $10 \%$ of the Al-SNF assemblies have corrosion or mechanical damage that has resulted in minor penetrations (breaches) of the aluminum cladding and exposure of the fuel core to the ambient environment. Although the cladding integrity is compromised, these assemblies retain sufficient strength and structural integrity for safe handling. In addition, since the fuel is metallurgically bonded to its cladding, a minor penetration of the cladding only allows a minor area of fuel exposure to the environment, thus maintaining general confinement under dry storage conditions. Therefore, these assemblies do not require special, additional canning before placement within the canister to meet the interim dry storage requirements and the repository requirements.

The following requirements for the Al-SNF form in its canister for road-ready, interim dry storage, originally reported in Reference 9, have been revised for purposes of clarity in this report. A discussion of the requirements is provided in italics. The canister used for the storage at SRS would be the DOE SNF canister to be placed within the waste package in the repository.

An interim dry storage system for both the direct Al-SNF form and the melt-diluted Al-SNF form should use these requirements as functional performance requirements.

1. Free water remaining within the sealed storage canister after drying is limited to maintain the hydrogen content less than 4 vol \%. 
The typical transfer of the Al-SNF assemblies from basin storage to dry storage will involve drying the fuel. The fuel may be dried separately, or it may be loaded underwater into a canister followed by drying the fuel/canister system before backfilling with helium (see item 5 below) and sealing for the direct-stored Al-SNF form. With time, the residual free water within the sealed canister will be consumed through corrosion and hydrogen gas would be evolved. The limit of 4 vol \% for hydrogen buildup is based on the generally recognized range of flammability of hydrogen in air as being from 4 vol $\%$ to $75 \mathrm{vol} \%$ with anything less than $4 \mathrm{vol} \%$ being considered as nonflammable [12]. Hydrogen generation can be predicted from the following (9-11):

$$
\frac{\text { Free Water }(\mathrm{g})}{\text { Canister Volume }\left(\mathrm{m}^{3}\right)}=292,505\left[\frac{\mathrm{P}_{\mathrm{H}_{2}}(\mathrm{~atm})}{\left(273.15+\mathrm{T}\left({ }^{\circ} \mathrm{C}\right)\right.}\right]
$$

Stated in other terms, the maximum allowable free water (W, in $\mathrm{ml}$ ), expressed as a function of the free volume of the canister $(V$, in $m 3)$ is given as:

$$
\mathrm{W}=38.7 \mathrm{~V}
$$

The requirement for a helium back-fill (see item 5 below) provides additional assurance that a flammable mixture will not be generated (4\% hydrogen in helium is a nonflammable mixture). Drying of the melt-dilute Al-SNF form would occur as an initial step in the melt process.

2. The lag storage, treatment, and canister storage environments shall limit general corrosion or pitting corrosion to less than $0.0076 \mathrm{~cm}(0.003 \mathrm{in}$.) in depth in SNF cladding or in exposed fuel material.

This requirement is related to retrievability as it defines the acceptable degradation or change in condition of the direct-stored Al-SNF form that is allowable throughout the transfer, treatment, and dry storage steps. The requirement is based on engineering judgment to provide for full handleability of the fuel if retrieval is necessary.

3. The canister storage environment shall preclude the plastic deformation of SNF elements to less than $2.54 \mathrm{~cm}$ (1.0 in.) over a fuel assembly length of $91.44 \mathrm{~cm}(3.0 \mathrm{ft})$. Deformation is not to exceed $75 \%$ of the clearance space between the fuel assembly and storage grid throughout the period of storage.

This requirement is related to retrievability as it defines the acceptable degradation or change in condition of the direct-stored Al-SNF form that is allowable during the interim dry storage period. The requirement is based on engineering judgment to provide for ready removal of the fuel from a canister and handleability of the fuel.

4. The interim storage environments shall prevent rupture of the SNF cladding due to creep or due to severe embrittlement.

This requirement is related to retrievability as it defines the acceptable degradation or change in condition of the direct-stored Al-SNF form that is allowable during the transfer, preparation, and dry storage steps. The requirement derives from 10 CFR 72 
[5] which precludes a gross cladding rupture during the storage and handling of spent fuel.

5. Canisters shall be backfilled with helium to 1.5 times atmospheric pressure at room temperature.

This requirement is based on the desire for compatibility of gases used within the canisters and the waste package itself as recommended by the DOE SNF Canister Task Group [13]. The heat transfer properties of helium would result in lower fuel temperatures (note that there is a temperature limit of $200^{\circ} \mathrm{C}$ for interim dry storage) and reduced degradation rates over that of other cover gases.

6. The storage facility shall be capable of handling canisters from 10 to 15 feet in length.

This requirement is primarily based on the present uncertainty associated with standard canister design development. Current approved designs include a 10 foot long canister for West Valley and DWPF and a recently approved 15 foot long canister for Hanford $H L W$ [13]. Final determination of the preferred SNF form for DOE SNF to be treated at SRS may result in a canister length other than 10 or 15 feet based on space utilization and criticality requirements, but the length finally selected is anticipated to be bounded by these two values.

7. The interim storage environment shall prevent the SNF cladding temperature from exceeding $200^{\circ} \mathrm{C}$.

A fuel temperature limit of $200^{\circ} \mathrm{C}$ was identified to avoid excess creep and the potential for hydrogen blistering of the aluminum fuel and cladding materials during drying and storage [10].

\subsection{References}

1 SRS SNF TSS Pre-Conceptual Design. G-CDP-00002, Rev. A (June 23, 1997).

2 WSRC-TR-98-00218. Functional Performance Requirements for a Proposed Treatment and Storage Facility for Spent Nuclear Fuel, July 1998.

3 WSRC-TR-98-00228, "Bases for Functional Performance Requirements for a Spent Nuclear Fuel Treatment and Storage Facility," Westinghouse Savannah River Co., July 1998.

4 Preliminary Throughput Evaluation for Spent Nuclear Fuel Transfer \& Storage Facility (U). G-ESR-G-00022, Rev. 0 (November 6, 1996).

5 "Licensing Requirements for the Independent Storage of Spent Nuclear Fuel and High-Level Radioactive Waste", Code of Federal Regulations, Chapter 10, Part 72.

6 "American National Standard Design Criteria for an Independent Spent Fuel Storage Installation (Dry Type)", ANSI/ANS-57.9.

7 Standard Guide for the Evaluation of Interim Spent Nuclear Fuel Dry Storage Systems for Extended Service. Draft under preparation by the LWR task group under the ASTM 26.13 subcommittee on Repository Waste. 
8 M. S. Abashian. Mined Geologic Disposal System Waste Acceptance Criteria. B000000000171704600-00095 REV00 (September 1997).

9 R. L. Sindelar and J. N. Baysden. SRS Transfer and Storage Services Technical Functional Performance Requirements for Dry Storage of Al-based SNF (U). WSRC-TR-97-00262, Westinghouse Savannah River Co. (September 1997).

10 R. L. Sindelar, H. B. Peacock, Jr., P. S. Lam, N. C. Iyer, and M. R. Louthan, Jr. Acceptance Criteria for Interim Dry Storage of Aluminum-Alloy Clad Spent Nuclear Fuel (U). WSRCTR-95-0347, Westinghouse Savannah River Co. (March 1996).

11 W. S. Large and R. L. Sindelar. Review of Drying Methods for Spent Nuclear Fuel (U). WSRC-TR-97-0075, Westinghouse Savannah River Co. (April 1997).

12 Gaseous Hydrogen Safety in a Confined Laboratory. User's Guide, DPST-82-717 (March 1982).

13 W. S. Large. "Trip Report - DOE SNF Canister Task Group Meeting at INEEL," SFS-SNF970061 (May 27, 1997). 


\subsection{DISPOSABILITY STANDARDS}

The DOE Office of Civilian Radioactive Waste Management (OCRWM) is responsible for developing and operating a geologic repository for storage of radioactive wastes. In addition to characterization of the site and performance assessment of the long-term behavior of radioactive waste, OCRWM is developing repository and waste package designs and detailed standards for radioactive wastes to be emplaced in the repository. The Mined Geologic Disposal System Draft Disposability Interface Specifications (MGDS-DIS) specifies the physical, chemical, and thermal characteristics that spent fuel, high level waste, and associated disposable canisters must conform to for emplacement in the repository [1]. These standards consolidate disposability issues from design and contractual documents into a single document for use by waste custodians in preparing wastes and obtaining certification for disposal in the MGDS. The MGDS-DIS will serve as input into the Waste Acceptance System Requirements Document [2].

The MGDS-DIS identify waste characteristics that must be met to ensure safe repository operation, acceptable long-term performance, and anticipated regulatory requirements within the MGDS and are based on repository designs and operational concepts as of September 1997. The requirements derive from standards for protection of the environment and public from releases of radioactive material established by the Environmental Protection Agency (EPA) and Nuclear regulatory Commission (NRC) requirements for evaluating applications to construct, operate, close, and decommission a repository. The standards do not cover interim storage prior to handling in the Surface Facilities of the MGDS or transport of the wastes from the generator sites to the MGDS. Development of the MGDS is an ongoing process and further evolution of individual disposability standards may be anticipated until such time as a construction permit for the MGDS has been issued by the NRC.

There are four categories of waste covered by the standards:

Intact Spent Fuel

Spent Fuel in Disposable Canisters

High-Level Waste

Other radioactive Waste

DOE-Savannah River has decided to place the Al-SNF in disposable canisters that do not need to be reopened before emplacement in the repository. The disposability standards applicable to DOEowned Al-SNF are contained in Section 4, Waste and Container Properties for Spent Fuel in Disposable Canisters, of the MGDS-DIS. The documentation requirements that must be met in order for wastes to be accepted into the MGDS will be specified in Section 8, which has not yet been written.

\subsection{Disposability Standards for SNF in Disposable Canisters}

Disposability standards for non-intact SNF and all SNF in disposable canisters are covered in Section 4 of the draft MGDS-DIS. The SNF includes BWR assemblies, PWR assemblies, and all DOE-owned SNF. In some cases, a standard applies to both commercial and DOE SNF. In other cases, separate standards have been written for commercial and DOE SNF. A disposable container is any container into which wastes are placed such that the canister and waste can be placed in the repository or inserted into a disposable container without repackaging. Wastes covered by this section include anything classified as SNF, including both the fuel bearing and nonfuel bearing components of SNF. Fuel bearing components include intact elements/assemblies, 
damaged elements/assemblies, intact fuel rods, rod segments, and fuel debris. Non-fuel bearing components consist of items irradiated during reactor operation and include:

The components used to initiate, control, and monitor the chain reaction in the core, often called non-fuel assembly (NFA) hardware (neutron sources, control elements, burnable absorbers, in-core instrumentation, etc.)

The non-fuel portion of a fuel assembly, often called disassembly hardware (guide tubes, water rods, grids, nozzles, end fittings, structural ties, etc.)

Miscellaneous irradiated hardware used in the reactor core but not part of fuel assemblies (dummy assemblies, coupon trees, etc.)

There are no plans at SRS to include any non-fuel components in shipments to the MGDS. All canisters would contain Al-SNF forms only.

Within this section, disposability standards for SNF in disposable canisters are organized into four categories:

General/Descriptive (Section 5.1.1),

Physical/Dimensional (Section 5.1.2),

Chemical Compatibility (Section 5.1.3)

Thermal/Radiation/Pressure (Section 5.1.4)

The first numeric in the Disposability Standard number designates the waste type, in this case 2 for $\mathrm{SNF}$ in disposable canisters. The second numeric denotes the four categories of standard as indicated above. The third numeric is a sequential counter for the waste form (1-19) and the canistered waste (20-39). The standards in the last two categories are potentially problematic as they will require data collection and analysis to demonstrate conformance and because the standards are uncertain at present and subject to change in the future.

The MGDS-DIS specifically identifies those draft standards that reflect only the generic language of 10 CFR 60.135 and where further analyses are planned for FY 1998 to support more specific disposability standards. In other cases, the draft disposability standards require verification. Draft disposability standards that have been designated in the MGDS-DIS for additional analyses or verification are identified in Section 5.1 by a double asterisk $\left.{ }^{* *}\right)$ following the title of the standard.

\subsubsection{Descriptive Disposability Standards}

Disposability Standards 2.1.1 through 2.1.4 apply to acceptance of DOE non-intact SNF in the MGDS. Both melt-dilute and direct forms must meet these standards. Disposability Standards 2.1.20 through 2.1.28 apply to disposable canisters in which SNF is placed. The combined waste and canister shall comply with these standards.

\subsubsection{Disposability Standard 2.1.1 - Compliance with NWPA Definition of Spent Nuclear Fuel}

Spent nuclear fuel is defined in the Nuclear Waste Policy Act (NWPA) of 1982 and the NWPA Amendments of 1987 as " fuel that has been withdrawn from a nuclear reactor following irradiation, the constituent elements of which have not been separated by reprocessing." This 
standard requires that waste in disposable canisters shall meet the legal definition of SNF. Fuel rods, assembly hardware, and non-fuel components are considered part of SNF.

\section{Melt-Dilute:}

Disposable canisters that contain Melt-Dilute Al-SNF forms comply with this definition even though there has been alteration in the physical form and release of some volatile fission product elements from the Al-SNF during the Melt-Dilute process. Each ingot produced by the MD process will contain the contents of several spent fuel elements. This process is not chemical reprocessing in the sense of the NWPA.

\section{Direct:}

Direct Al-SNF forms clearly comply with the legal definition of SNF in the NWPA. Each canister will contain several intact assemblies of Al-SNF.

\subsubsection{Disposabilitv Standard 2.1.2 - Minimum Cooling Time since Discharge}

The Standard Contract (10 CFR 961.11, Appendix E, Section B.3) defines commercial SNF that is discharged from the reactor and subsequently cooled for less than five years to be "non-standard." This disposability standard restricts MGDS acceptance of these wastes to ensure that internal waste package temperature and total thermal outputs from waste packages remain within acceptable limits. SNF that is discharged from the reactor and allowed to cool for less than five years before delivery to the MGDS shall not be accepted into the MGDS.

\section{Melt-Dilute:}

This draft Disposability Standard does not explicitly include DOE-owned SNF; however, cooling times for all DOE-owned Al-SNF are expected to exceed five years. Furthermore, the DOE-owned SNF will comply with Standard 2.4.20 limiting total thermal output to $<1500 \mathrm{~W}$ at time of delivery to the MGDS and to Standard 2.4 .21 which limits cladding temperature to $<350^{\circ} \mathrm{C}$ in repository disposal.

\section{Direct:}

This draft Disposability Standard does not explicitly include DOE-owned SNF; however, cooling times for all DOE-owned Al-SNF are expected to exceed five years. Furthermore, the DOW-owned SNF will comply with Standard 2.4.20 limiting total thermal output to $<1500 \mathrm{~W}$ at time of delivery to the MGDS and to Standard 2.4.21 which limits cladding temperature to $<350^{\circ} \mathrm{C}$ in repository disposal.

\subsubsection{Disposability Standard 2.1.3 - SNF as a Solid}

Waste accepted by the MGDS shall be in solid form at temperatures ranging from $25^{\circ} \mathrm{C}$ to $400^{\circ} \mathrm{C}$ and a pressure of 1 to $5 \mathrm{~atm}$ (surface to peak repository conditions and internal waste package environment).

\section{Melt-Dilute:}

All metallic phases present in the SNF form produced by the MD process are solid under the conditions specified. In the melt-dilute process, SNF assemblies are melted and depleted uranium is added to dilute the $\mathrm{U}^{235}$ concentration to less than $20 \%$ and aluminum is added as needed to adjust the overall uranium content to the desired concentration. Regardless of the final uranium concentration chosen for 
the aluminum-uranium alloys the minimum melting temperature is $646^{\circ} \mathrm{C}$ for any

phase or combination of phases in the Al-U system.

\section{Direct:}

Al-SNF assemblies are solid under the temperature and pressure conditions cited. Materials present in the SNF assemblies are the aluminum cladding alloys (1100, 5052, and 6061), aluminum with 0.005 at. \% uranium, aluminum-uranium intermetallic compounds, silicon-uranium intermetallic compounds, and uranium oxides. The melting points of 1100,5052 , and 6061 aluminum alloys are 643 , 607 , and $582^{\circ} \mathrm{C}$, respectively. The minimum melting point in the aluminumuranium alloy system is $646^{\circ} \mathrm{C}$, the eutectic temperature between aluminum and $\mathrm{UAl}_{4}$. The lowest melting point of any constituent in the silicon-uranium system is $785^{\circ} \mathrm{C}$, the eutectic between uranium and $\mathrm{U}_{3} \mathrm{Si}_{2}$. All oxides of uranium melt at temperatures above $1000^{\circ} \mathrm{C}$.

\subsubsection{Disposability Standard 2.1.4 - Provision that Wastes Other than Intact SNF be Canistered}

All SNF not classified per 10 CFR 961.11, Appendix E as either standard (S-1 or S-2) or as nonstandard categories NS-1 (Physical Dimensions) and NS-3 (Short Cooled), or can be shown to meet an equivalent definition for non-commercial SNF, shall be placed into disposable canisters (i.e., canisters that can be placed into a disposable container without emptying and repackaging canister contents) prior to shipment to the MGDS. These canisters must comply with Disposability Standards 2.1.20 through 2.1.28 in Section 5.1.2.

\section{Melt-Dilute:}

All DOE-owned SNF intended for final disposition in a geologic repository would be seal-welded in stainless steel disposable canisters prior to interim dry storage at SRS. These canisters would be road-ready and meet the requirements for subsequent shipment and disposal in the MGDS.

\section{Direct:}

See above

\subsubsection{Disposabilitv Standard 2.1.4.1 - Canistering of Degraded or Damaged Spent Nuclear Fuel}

Any SNF assembly that lacks the structural integrity to be lifted intact (e.g., handling features damaged) or has fuel cladding degradation or damage such that it is classified as failed per 10 CFR 961.11, Appendix E (Section C.3), or its equivalent if non-commercial, shall be placed in disposable canisters before delivery to the MGDS. Structural integrity is defined as maintaining cladding integrity while the assembly is handled remotely, as discussed in Disposability Standard 2.2.22. SNF cladding integrity is considered damaged, and therefore subject to the assembly being canistered under this standard, if any of the following conditions are met.

- Visual evidence suggests that cladding corrosion or abrasion penetrates the entire thickness of the cladding at any point on any fuel rod.

- The assembly was stored in a facility or storage device not licensed in accordance with 10 CFR Parts 50 or 72 , or is subjected to temperature-pressure conditions that exceed license requirements.

- The assembly was transported in a cask not licensed in accordance with 10 CFR Part 71, or is subjected to temperature-pressure conditions that exceed license requirements. 
- Knowledge or records such that cladding damage can be reasonably assumed to jeopardize cladding integrity.

\section{Melt-Dilute:}

In the Melt-Dilute process, the fuel assemblies are melted and turned into solid ingots of a uranium-aluminum alloy; therefore, any damage that may have occurred to the fuel assemblies is no longer of concern. Any damaged assemblies that are received at SRS are acceptable for Melt-Dilute treatment.

\section{Direct:}

In the Direct disposal option, all fuel assemblies, including those with minor damage, would be placed in disposable canisters for shipment to MGDS. Approximately $7 \%$ of expected FRR SNF receipts have minor cladding penetrations [3]. Per the draft SRS EIS, all heavily damaged Al-SNF would be considered for reprocessing at SRS.

\subsubsection{Disposability Standard 2.1.4.2 - Canistering of SNF Debris and Corrosion Products}

All fuel debris and corrosion products not physically fixed to the surface of an intact SNF assembly or that can be easily removed when lifting the assembly through water shall be placed in a disposable canister.

\section{Melt-Dilute:}

Canisters may contain minor amounts of slag from the melt-dilute process. This standard allows for their disposal in the disposable canister.

\section{Direct:}

Minor amounts of corrosion products primarily from the Al-SNF cladding are anticipated. This standard allows for their disposal in the disposable canister.

\subsubsection{Disposability Standard 2.1.4.3 - Canistering of Non-Fuel Components}

Non-fuel components no longer physically part of an assembly shall be placed into a disposable container prior to acceptance into the MGDS. This standard allows disposal of end fittings etc. (if cropped from assemblies at SRS) in MGDS.

No non-fuel components at SRS are targeted for disposal in the MGDS.

\subsubsection{Disposability Standard 2.1.20 - Disposable Canister Material}

This disposability standard specifies the materials of construction for disposable canister shells, baskets, shield plugs, and neutron absorbers that are accepted at the MGDS. The sealed disposable canister and any associated internals shall meet the requirements of 10 CFR Part 71 for the transportation package, including requirements for maintaining structural integrity and the spacing of the spent fuel assemblies. The requirements are based on compatibility of canister with other materials in the waste package and MGDS such that the waste package integrity and long term repository performance are not compromised.

Canister Shell and Lids - The standard specifies low carbon stainless steel (e.g., ASTM Standard A240) or a stabilized austenitic stainless steel for these canister components. 
Neutron Absorber Material - austenitic stainless steel with finely dispersed boron phase or zirconium-hafnium alloys can be used. Aluminum alloys containing boron are only allowed if long term criticality control is not an issue.

Shield Plug - Depleted uranium sheathed in a compatible material - stainless or carbon steel; or other high-density materials except lead may be used without sheathing if compatible with the basket and shell materials.

\section{Melt-Dilute:}

The materials of construction of the canisters [4] conform to the requirements of this standard. Austenitic stainless steel XM-19 (Nitronic-50) is currently specified as the material of construction for the canister shell and lids. ASTM Standard A240 applies to heat resistant stainless steels in plate, sheet, and strip form for use in pressure vessels and includes XM-19 (Nitronic-50).

The Melt-Dilute SNF form contains $20 \%$ or less of HEU. Neutron absorbing materials, if required, will be added to the melt to become an integral part of the SNF form. The product of the Melt-Dilute process is a solid mass that fits into the canister; therefore, separators and baskets are not required in the canister.

\section{Direct}

The materials of construction of the canisters [4] conform to the requirements of this standard. Austenitic stainless steel XM-19 (Nitronic-50) is currently specified as the material of construction for the canister shell and lids. ASTM Standard A240 applies to heat resistant stainless steels in plate, sheet, and strip form for use in pressure vessels and includes XM-19 (Nitronic-50).

The basket and separator materials in the canisters for Direct Co-Disposal are currently specified as borated Type 316L austenitic stainless steel and comply with this standard. Alternate poison materials may be needed to demonstrate compatibility with the Al-SNF [5,15]. Candidate materials are being evaluated to show that they remain effective in maintaining the reactivity of all possible configurations to within the acceptable limit (see standard 2.3.22). It is assumed that the DIS standard will be revised to include the selected neutron absorber material.

The inner shield plug in the current design is Type $316 \mathrm{~L}$ austenitic stainless steel and is approximately 5 -inches thick. There is no mention of depleted uranium or other high-density material in the plug.

\subsubsection{Disposability Standard 2.1.21 - Canister Sealing}

Canisters shall be sealed prior to delivery to the MGDS to maintain material accountability, avoid release of canister contents, and prevent introduction of water or contaminants. Disposable canisters shall be vacuum dried, backfilled with an inert gas and sealed. There is no prescribed method of sealing canisters, although the preference is seal-welded. The seal must prevent introduction or loss of radioactive gases, liquids, and particulates. The canister shall prevent the introduction of oxygen in quantities that can accelerate degradation of the wastes. Once sealed the canister shall meet the leak-rate defined in Disposability Standard 2.4.24. 


\section{Melt-Dilute:}

All canisters for DOE-owned Al-SNF are to be seal welded and hence will comply with this standard.

Direct:

See above

\subsubsection{Disposability Standard 2.1.22 - Limits on Free Liquid in Canistered Spent Nuclear Fuel**}

Free liquids in canistered SNF are not acceptable at the MGDS because they provide a potential mechanism for transport of radionuclides from the repository to the accessible environment and they may make any release from a preclosure accident more difficult to contain. Free liquids also may enhance internal pressurization of waste packages, provide a degradation mechanism for any $\mathrm{SNF}$, provide a mechanism for waste package degradation, and can accelerate hydrogen gas generation. Free liquids including water, organic liquids, and inorganic liquids in disposable canisters delivered to the MGDS are restricted by this disposability standard to an amount that does not compromise the ability of the waste package to meet preclosure safety requirements or to achieve long-term performance objectives. Residual moisture shall be eliminated or reduced as much as possible in accordance with Disposability Standard 2.1.21. Dewatering and purging as suggested in NUREG-1567, pp. 11-24 are recommended.

\section{Melt-Dilute:}

The as-cast Melt-Dilute form will be free of free water and both organic and inorganic liquids because of the high temperature $\left(\sim 800^{\circ} \mathrm{C}\right)$ in the melting process. Handling of the cast forms and packaging in disposable canisters would be controlled to avoid pickup of inorganic or organic liquids. The canisters will be evacuated, dried, and backfilled with helium before seal welding.

\section{Direct:}

Water remaining within the sealed canister after drying would be limited to maintain the hydrogen content to less than 4 volume $\%$, the flammability limit for hydrogen in air (see the discussion of Disposability Standard 2.1.25 on combustible materials in Section 5.1.3.3). The maximum allowable free water ( $\mathrm{W}_{\text {water }}$, in $\left.\mathrm{ml}\right)$, expressed as a function of the free volume $\left(\mathrm{V}, \mathrm{m}^{3}\right)$ of the container, is given as:

$\mathrm{W}_{\text {water }}=38.7 \mathrm{~V}$

Minimizing corrosion and excessive $\mathrm{H}_{2}$ buildup in a DOE SNF canister is achieved by drying the Al-SNF to remove free water since $\mathrm{H}_{2}$ is generated through corrosion reactions of water with aluminum.

Free water within a disposable canister can be removed by vacuum drying. A specification for vacuum drying is established to limit free water in the canister. The Al-SNF must be vacuum dried to below 5 torr at an internal chamber temperature of $25^{\circ} \mathrm{C}\left(77^{\circ} \mathrm{F}\right)$ or higher. The vapor pressure of water at $25^{\circ} \mathrm{C}\left(77^{\circ} \mathrm{F}\right)$ is 24 torr, and any free liquid water on the fuel will be vaporized before 5 torr is reached. To ensure dryness, the vacuum pump should be isolated following drying and the chamber interior pressure must remain at or below 5 torr for a set time to confirm dryness. 
Recent field experience with two instrumented, shielded SNF test canisters indicates a continuous warm air purge $\left(<74^{\circ} \mathrm{C}\left(165^{\circ} \mathrm{F}\right)\right)$ under vacuum provides satisfactory dryness in a reasonable time interval. A canister containing one spent fuel assembly and $\sim 0.6$ pints of water was dried to $\sim 0.25$ torr in 2.5 hours. The warm air purge was an improvement over previous tests with unheated vacuum drying [6] in terms of time to dry and avoidance of the potential for water freezing. An air-cooled vacuum pump was used to eliminate the need for cooling water disposal with a water-cooled pump. The absence of free water during drying can be determined by monitoring the canister pressure, relative humidity, or fuel/can temperature during drying [6].

After drying, the canister will be backfilled with helium and welded shut. The potential to produce a flammable mixture would be essentially eliminated.

The drying requirments imposed for interim dry storage ensure that repository standards 2.1.22 and 2.1.25 would be met.

\subsubsection{Disposability Standard 2.1.23 - Maximum Allowable Quantity of Particulates**}

Particulate waste forms shall be consolidated by incorporation into an encapsulating matrix to limit the availability and generation of particulates. Preclosure safety and long term performance constraints require that wastes containing unconsolidated particulate matter be restricted. Particulates provide a potential airborne pathway for contaminant release during repository operations and are subject to high radionuclide dissolution rates when exposed to water. Particulates generated by degradation of uranium metal may be chemically reactive or pyrophoric.

\section{Melt-Dilute:}

The melt-dilute form is a solid mass of cast alloy consisting of aluminum and $\mathrm{UAl}_{4}$ and is not a particulate. Experience in handling casting of the melt-dilute form indicate that the casting is resilient and would not generate fines during handling, transport, and storage.

\section{Direct:}

The direct form consists of intact fuel assemblies that are massive solids. There may be some minor adherent corrosion product, but the SNF form itself is not a particulate. Al-SNF fuel assemblies remain tough and ductile after irradiation and the limitation of free water in the disposable canister would not lead to the generation of particulates during handling, shipment, and pre-containment storage and disposal.

\subsubsection{Disposability Standard 2.1.24 - Limits on Pyrophoric Materials**}

The contents of the disposable canister shall contain no pyrophoric materials in an amount that could compromise surface facility or repository preclosure safety or repository long term performance. Wastes expected to be pyrophoric under conditions ranging from $25^{\circ} \mathrm{C}$ to $400^{\circ} \mathrm{C}$ and 1 to $5 \mathrm{~atm}$ are excluded from MGDS.

\section{Melt-Dilute:}

Aluminum corrosion generates hydrogen and, if uranium is present, $\mathrm{UH}_{3}$, a compound that is pyrophoric under certain conditions, could theoretically be produced. The melt-dilute 
forms for the aluminum-based fuels (i.e., $\mathrm{UAl}_{4}, \mathrm{U}_{3} \mathrm{Si}_{2}$, or $\mathrm{U}_{3} \mathrm{O}_{8}$ in aluminum) are dispersions of $\mathrm{UAl}_{4}$ in aluminum possibly with some small amounts of uranium-aluminum silicides in the melt-dilute product of the $\mathrm{U}_{3} \mathrm{Si}_{2}-\mathrm{Al}$ fuels (see Appendix A). Compounds of $\mathrm{UAl}_{4}$ and $\mathrm{U}_{3} \mathrm{Si}_{2}$ would not be reduced by expected hydrogen pressures ( $4 \mathrm{vol} . \%$ or less) to produce $\mathrm{UH}_{3}$.

\section{Direct:}

Aluminum, the cladding material and the matrix material of Al-SNF, is a metal not normally combustible [7]. Uranium metal is combustible and may readily ignite if finely divided. Uranium hydride, $\mathrm{UH}_{3}$, is pyrophoric and its formation must be considered in the safe handling, storage, and disposition of uranium metal fuel $[7,8]$. The potential pyrophoricity of uranium metal, aluminum-clad fuels retrieved from underwater storage at SRS has been evaluated [9]. Results of this evaluation indicate that the production of pyrophoric corrosion deposits on these fuels is not anticipated.

Aluminum-based fuels (i.e. particles of $\mathrm{UAl}_{4}, \mathrm{U}_{3} \mathrm{Si}_{2}$, or $\mathrm{U}_{3} \mathrm{O}_{8}$ in aluminum) are not pyrophoric. Several contributing factors to this conclusion are given as follows:

Compounds of $\mathrm{UAl}_{4}, \mathrm{U}_{3} \mathrm{Si}_{2}$, and $\mathrm{U}_{3} \mathrm{O}_{8}$ would not be reduced by the anticipated hydrogen pressures $(<<1 \mathrm{~atm})$ to produce $\mathrm{UH}_{3}$. Oxides of uranium could be reduced and $\mathrm{UH}_{3}$ could be formed if the partial pressure of $\mathrm{H}_{2} \mathrm{O}$ were low enough and the partial pressure of $\mathrm{H}_{2}$ were high enough in an $\mathrm{H}_{2} \mathrm{O} / \mathrm{H}_{2}$ system. In addition, because aluminum completely surrounds the oxide particles, direct contact of the environment with a significant number of fuel particles cannot occur. This is consistent with the lack of observed $\mathrm{UH}_{3}$ following corrosion of $\mathrm{U}_{3} \mathrm{O}_{8}$ in aluminum.

A standard guide for pyrophoricity testing specifically for metallic uranium spent nuclear fuel is presently under development by a task group of the ASTM [10]. The Al-SNF is not subject to this standard guide. However, the test protocols described therein could be applied to validate the demonstration that Al-SNF to be placed within the disposable canisters is not pyrophoric or combustible.

\subsubsection{Disposability Standard 2.1.25 - Limits on Combustibles, Explosives, or Chemically Reactive Waste Forms**}

Canisters are excluded from MGDS that contain compounds in concentrations considered combustible, explosive under $49 \mathrm{CFR} 173.50$, or chemically reactive under conditions ranging from $25^{\circ} \mathrm{C}$ to $400^{\circ} \mathrm{C}$ and 1 to $5 \mathrm{~atm}$. This disposability standard restricts disposable canisters containing wastes that could be combustible, explosive, or chemically reactive over the temperature and pressure ranges in the repository or supporting surface facilities.

\section{Melt-Dilute:}

Aluminum and uranium compounds in the melt-dilute castings are not combustible or explosive. Drying requirements at SRS limit moisture so that any potential hydrogen generation from reaction of aluminum with moisture is below the flammability limit of $4 \mathrm{vol} \%$ hydrogen in air. The lower concentration limit of flammability of hydrogen is 4 percent by volume in air at room temperature. The lower concentration level for a sustained burn of hydrogen in air is approximately 
9 percent by volume in air. The concentration level at which a hydrogen/air mixture is explosive is 18 percent. The lower limit of flammability is applied as a limit to the amount of hydrogen generated in the canisters.

The hydrogen generation can be estimated either by the bayerite/gibbsite reaction (predominant below about $80^{\circ} \mathrm{C}$ )

$2 \mathrm{Al}+6 \mathrm{H}_{2} \mathrm{O} \rightarrow \mathrm{Al}_{2} \mathrm{O}_{3} \cdot 3 \mathrm{H}_{2} \mathrm{O}+3 \mathrm{H}_{2}$

or by the boehmite reaction (predominant above about $80^{\circ} \mathrm{C}$ )

$2 \mathrm{Al}+4 \mathrm{H}_{2} \mathrm{O} \rightarrow \mathrm{Al}_{2} \mathrm{O}_{3} \cdot \mathrm{H}_{2} \mathrm{O}+3 \mathrm{H}_{2}$

In the above equations, one mole of hydrogen is generated by two moles of water when the corrosion product is bayerite or gibbsite; and is generated by $4 / 3$ moles of water when boehmite is formed at higher temperature. For the Al-SNF in the canister storage condition, the hydrogen generation depends on the amount of moisture allowed inside the canister before it is sealed. For example, if the volume fraction of hydrogen is limited to $\mathrm{X}$ and the free volume of the canister is $\mathrm{V}$, then the allowable water in milligrams ( $\mathrm{mg}$ ) is approximately $\mathrm{XV}$, where $\mathrm{V}$ is in cubic centimeters (cc). In general, the explosion limit for hydrogen volume fraction is $4 \%$. Therefore, the water in the canister should dry to less than $0.04 \mathrm{~V} \mathrm{mg}$. Note that the more conservative boehmite reaction was used. However, in a breached canister where water may be unlimited, the hydrogen will continue to generate until all the aluminum alloys are consumed by corrosion process.

\section{Direct:}

The discussion for the Melt-Dilute SNF form also applies to the direct SNF form.

\subsubsection{Disposability Standard 2.1.26 - Disposable-Canister Permanent Labeling}

All disposable canisters entering the MGDS shall have an alphanumeric identifier unique to that waste generator. This unique identifier shall be visible from the top and side of the canister. The identifier shall be in the form of a label that is an integral part of the canister, can be reasonably expected to remain legible for 100 years at temperatures of $25^{\circ} \mathrm{C}$ to $400^{\circ} \mathrm{C}$, does not impair the integrity of the canister, is chemically compatible with the canister, and does not cause the dimensional limits of the canister to be exceeded. Multi-element canisters shall also have an exterior marking to indicate the orientation of the SNF basket within the canister.

\section{Melt-Dilute:}

All disposable canisters of DOE-owned SNF will be labeled in conformance with this standard as specified in the Functional Performance Requirements for the TSF $[11,12]$.

\section{Direct:}

(See above)

\subsubsection{Disposability Standard 2.1.27 - Tamper-Indicating Devices on Canisters not Weld-Sealed}

Safeguards and security requirements defined by the NRC rely in part on the use of tamperindicating devices (TID) on transportation casks and canisters not weld-sealed to ensure that 
wastes have not been removed or disturbed. This disposability standard mandates the use of these devices on canisters that are not seal-welded and contain wastes regulated by the NRC as strategic special nuclear material. There are no provisions for TIDs on canisters containing exempted special nuclear material as defined in 10 CFR $73.26(\mathrm{~g})(3)$. Canisters containing strategic special nuclear material shall have a NRC approved TID in accordance with NRC material control and accounting requirements in 10 CFR 74.55(a)(1) and (2).

All canisters originating at SRS are to be seal welded; therefore, this disposability standard is not applicable to canisters containing DOE-owned Al-SNF forms.

\subsubsection{Disposability Standard 2.1.28 - Disposable Canister Physical Condition}

Disposable canisters and their contents shall be capable of being transferred from their transportation cask into disposable containers at the MGDS. Disposable canisters must maintain their integrity and prevent loss of contents during transfer. The disposable canisters must be dimensionally compatible with the disposal container and the transportation cask.

All provisions for this disposability standard are covered by other disposability standards as follows:

- Damage or deformation to the disposable canister in the form of bulges, swelling, or dents shall be limited such that the canister continues to meet the dimensional envelope defined in Disposability Standard 2.2.20

- Dents, holes, and corrosion shall be limited such that the structural integrity of the canister to be lifted and moved intact using remote waste-handling equipment is not adversely affected per Disposability Standard 2.2.22.

- Dents, holes, and corrosion shall be limited such that there is no compromise to the canister integrity (e.g., maintain a seal per Disposability Standards 2.1.21 and 2.4.24).

\subsubsection{Physical/Dimensional Standards for Canistered Waste}

The following dimensional standards apply to all disposable canisters that contain SNF and to the combined waste and loaded disposable canister.

\subsubsection{Disposability Standard 2.2.20 - Dimensional Envelopes for Disposable Canisters Containing SNF}

Wastes arriving at the MGDS must be within prescribed size limits in order to be unloaded from casks, handled safely in the surface facilities, and loaded into disposable containers. The two principle reasons for specifying size limits and tolerances are interfaces with waste handling equipment (minimum and maximum reach, dimensions in pool racks, etc.) and compatibility with cavities in disposal containers.

\subsubsection{Disposability Standards 2.2.20.1 and 2.2.20.2}

These standards apply to disposable canister dimensions for commercial SNF. Disposable canister dimensions for DOE-Owned SNF are covered in the following standard. 


\subsubsection{Disposability Standard 2.2.20.3 - Dimensional Envelope for Disposable DOE-Owned Spent Nuclear Fuel Canisters**}

This standard defines the acceptable dimensions for disposable DOE-owned SNF canisters to ensure compatibility with disposable container cavities. Disposal containers may be designed either for co-disposal of HLW and DOE-owned SNF or for disposal of DOE-Owned SNF canisters only. The standard also addresses acceptable canister dimensional tolerances. This disposability standard reflects the DOE SNF and HLW co-disposal option. Planned efforts to refine the DOE-owned SNF waste package designs and DOE-EM work to standardize DOE-owned canister designs may result in more than one DOE-owned SNF disposal container and further divide this standard for DOE-owned SNF [4].

The canisters of DOE-owned SNF that will be placed in disposal containers without being opened at the MGDS shall have the capability to stand upright without support on a flat horizontal surface, shall have a diameter not less than 16 inches nor more than 24 inches, and shall have an overall length no less than 120 inches nor more than 180 inches. The canister shall be capable of fitting without forcing (when lowered vertically) into a right-circular cylindrical cavity whose dimensions are one inch larger than the maximum canister dimension.

\section{Melt-Dilute:}

The current canister design for codisposal of DOE-owned SNF has an outside diameter of 17.3 inches and a length of 117.9 inches. The diameter is within the specified range (16 to 24 inches); however, the length is slightly less than specified in the standard (120 to 180 inches)

Outside diameter

17.3 inches $(439.3 \mathrm{~mm})$

Wall thickness

0.59 inches $(15 \mathrm{~mm})$

Overall length

117.9 inches $(409.3 \mathrm{~mm})$

The canister design is subject to revision.

\section{Direct:}

The canister for direct disposal of Al-SNF is the same as for the melt-dilute option.

\subsubsection{Disposability Standard 2.2.21 - Maximum Loaded Weight of Disposable Canisters Containing Spent Nuclear Fuel}

Canistered wastes arriving at the MGDS must meet prescribed weight limits in order to be handled safely in the surface facilities, and to ensure that waste packages do not exceed weight limits once canistered wastes are loaded into them. Canisters to be accepted into the MGDS shall meet the following weight limits and tolerances.

Disposability Standards 2.2.21.1 and 2.2.21.2 apply to single element and multi-element canisters for commercial SNF. Canistered weight for DOE-SNF is covered in the following standard. 


\subsubsection{Disposability Standard 2.2.21.3 - Weight of Disposable DOE-Owned Spent Nuclear Fuel Canisters**}

Canisters of DOE-owned SNF that will not be unloaded prior to emplacement must be of a weight to ensure that the waste packages loaded with these canisters do not exceed total weight limits. Candidate waste packages include those that co-dispose HLW and DOE-owned SNF and ones designed exclusively for DOE-owned SNF. This standard provides that the canisters of DOEowned SNF shall have a weight that does not exceed 2750 pounds.

The weight limit in the Draft Disposability Interface Specification [1] is substantially less than the 5004 pounds specified in the December 1997 Interface Control Document for DOE Spent SNF [2].

\section{Melt-Dilute:}

The total weight of a canister containing three SNF forms from the Melt-Dilute treatment option is estimated as 3786 pounds and exceeds the requirements of this standard. The weight limit has not been verified and canister designs and weights are subject to modification.

Typical Loaded Canister Weight:

Empty canister shell with lids 1459 pounds

Three melt-dilute forms 2327 pounds

Total 3786 pounds

Direct:

The conceptual canister design for Direct Codisposal of Al-SNF will accommodate 40 typical material test reactor (MTR) assemblies. The total weight of canister, baskets, and fuel assemblies is estimated as 2867 pounds. When loaded with 64 rhomboidal assemblies of the MIT design, the canister weight is estimated as 3006 pounds. In both cases, the canister weight exceeds the specified limit of 2750 pounds. The weight limit has not been verified and canister designs and weights are subject to modification. It is anticipated that the weight standard in future revisions of the DIS would accomodate the Al-SNF canister weights.

Typical Loaded Canister Weight

MTR assemblies:

Empty canister shell with lids 1459 pounds

Four baskets 930 pounds

40 MTR assemblies $\quad 477$ pounds

Total 2867 pounds

MTT assemblies:

Empty canister shell with lids 1459 pounds 


$\begin{array}{lcc}\text { Four baskets } & 1171 & \text { pounds } \\ \text { 64 MIT assemblies } & 376 & \text { pounds } \\ \text { Total } & 3006 & \text { pounds }\end{array}$

\subsubsection{Disposability Standard 2.2.22 - Capability to Lift Vertically with Remote Handling Fixtures}

Canistered SNF arriving at the MGDS in transportation casks must be unloaded by raising the cask to a vertical position and removing the canisters. Canisters are then either loaded into disposal containers or opened and contents unloaded. All canisters must be capable of being lifted vertically fully loaded using remotely engaged hooks, grapples or other lifting fixtures at the various stages of unloading, moving, repackaging, and storage. Canisters shall have lifting features that will be accessible and structurally sound to allow lifting vertically with canister handling equipment.

\subsubsection{Disposability Standard 2.2.22.1 Capability to Lift Commercial SNF Canisters}

This standard applies to disposable canisters for commercial SNF only.

\subsubsection{Disposability Standard 2.2.22.2 - Lifting Capability for Disposable DOE- Owned SNF Canisters}

Disposable canisters delivered to the MGDS shall have lifting features that are compatible with remote handling equipment (cranes, hooks, and grapples) and have the necessary structural integrity to be lifted vertically. These features include a lifting pintle, a standard dimensional interface, and a means to grapple and secure the pintle for lifting. The standard dimensional interface includes a lifting flange and a canister neck with adequate clearance to interface with lifting devices.

Canister designs for the melt-dilute and direct forms are incomplete. The Functional Performance Requirements for the TSF specify that the canister designs comply with this Disposability Standard [12].

\subsubsection{Chemical Compatibility Standards for Canistered Waste}

The Chemical Compatibility Standards for Canistered Waste include limits on the total radionuclide inventory, fissile material, and criticality potential and are subject to revision until such time as the Performance Assessment (PA) has been completed and accepted by the NRC. The limits given in these disposability standards are subject to change as PA models are improved and verified and new EPA or NRC regulations are promulgated. The possibility for changes in the limits in these standards has a direct impact on the fuel characterization requirements to demonstrate conformance of the direct disposal option to the standards.

\subsubsection{Disposability Standard 2.3.20 - Limits on Radionuclide Inventories in Canistered Spent Nuclear Fuel}

Repository preclosure safety and acceptable long-term performance require that SNF contain no more than a defined upper-bound on radionuclides. This disposability standard requires that 
information on radionuclide inventories in canisters delivered to the MGDS be provided and that these inventories comply with the conditions of the MGDS operating permits and licenses.

Disposability Standard 2.3.20.1 specifies Limits on Radionuclide Inventories in Single Element Canisters and does not apply to Disposable Canisters of DOE-SNF as these will contain multiple elements and are covered by the following standard.

\subsubsection{Disposability Standard 2.3.20.2 - Limits on Radionuclide Inventories in Multi-Element Canisters}

This standard requires that information on radionuclide inventories in disposable multi-element canisters delivered to the MGDS be provided. Where operating histories of the reactors are available, initial enrichment, burn-up, and cool-down times for SNF assemblies are to be provided. Where such information is not available, radionuclide inventory information for the following isotopes are to be provided:

\section{Table 5.1 Radionuclide Inventory Requirements}

\begin{tabular}{|c|c|c|}
\hline${ }^{227} \mathrm{Ac}$ & ${ }^{129} \mathrm{I}$ & ${ }^{239} \mathrm{Pu}$ \\
\hline${ }^{241} \mathrm{Am}$ & ${ }^{93} \mathrm{Nb}$ & ${ }^{240} \mathrm{Pu}$ \\
\hline${ }^{242 \mathrm{~m}} \mathrm{Am}$ & ${ }^{94} \mathrm{Nb}$ & ${ }^{241} \mathrm{Pu}$ \\
\hline${ }^{243} \mathrm{Am}$ & ${ }^{59} \mathrm{Ni}$ & ${ }^{242} \mathrm{Pu}$ \\
\hline${ }^{14} \mathrm{C}$ & ${ }^{63} \mathrm{Ni}$ & ${ }^{226} \mathrm{Ra}$ \\
\hline${ }^{36} \mathrm{Cl}$ & ${ }^{237} \mathrm{~Np}$ & ${ }^{228} \mathrm{Ra}$ \\
\hline${ }^{244} \mathrm{Cm}$ & ${ }^{231} \mathrm{~Pa}$ & ${ }^{79} \mathrm{Se}$ \\
\hline${ }^{245} \mathrm{Cm}$ & ${ }^{210} \mathrm{~Pb}$ & ${ }^{151} \mathrm{Sm}$ \\
\hline${ }^{6} \mathrm{Cm}$ & ${ }^{107} \mathrm{Pd}$ & ${ }^{126} \mathrm{Sn}$ \\
\hline${ }^{135} \mathrm{Cs}$ & ${ }^{238} \mathrm{Pu}$ & ${ }^{99} \mathrm{Tc}$ \\
\hline
\end{tabular}

There are currently no restrictions on the concentrations of individual radionuclides in individual canisters, although terms of repository operating license and permits may place additional restrictions.

\section{Radionuclide Inventories - DOE-SNF}

The following section gives radionuclide inventories for typical Foreign Research Reactor Fuels, as they would come to SRS for Interim Storage. These levels of activity are for a one-year cooling period. Typically FRR fuel will have a significantly longer cooling time and radionuclide levels will be much lower:

Foreign research reactors use a number of different fuel designs [see Appendix A]. These can be grouped into five categories: (1) plate-type, (2) concentric tube-type, (3) pin-type, (4) specialtype, (5) rod-type. The first 4 designs are aluminum-based while the fifth is a TRIGA type. The plate and tube types of (1) and (2) are known as MTR fuels. MTR fuels are used in a majority of the foreign research reactors. For the typical plate type design, the fuel assembly has a box-like housing about four feet in length with two outside housing plates and two outside fuel plates. The number of fuel elements in an assembly varies between 6 and 23 , and the initial ${ }^{235} \mathrm{U}$ content varies between 37 grams and 420 grams per assembly. The average burnup of a discharged SNF 
assembly varies between 15 and $76 \%\left({ }^{235} \mathrm{U}\right.$ percent). The uranium enrichment in MTR type fuel varies from just below 20 to 93 percent.

The spent nuclear fuel inventory is directly related to the initial mass of fuel, the level of burnup, and the cooling period (decay time) following discharge from the reactor. The radionuclide generation in an irradiated fuel is a function of reactor power level and the duration of the irradiation process.

The EIS divides the foreign reactor fuels into 3 classes and 4 fuel categories for determination of bounding radionuclide inventories. The selected fuel types are:

1. Special. Aluminum-based fuels that are neither TRIGA nor MTR.

1a. Single Element Reactors. From research reactors that operate with one element.

1b. NRU Type Spent Nuclear Fuel. SNF from Canadian Research Laboratories' research reactors that require special transportation.

2. MTR Spent Nuclear Fuel. This category covers all MTR-type SNF.

3. TRIGA Spent Nuclear Fuel. SNF from TRIGA reactors.

A series of ORIGEN 2 computer runs was made using different SNF within each fuel type assuming that each fuel was cooled for a specified period after its discharge from the reactor. Using the shortest period of 1 year for a Pegasus transportation cask, the bounding elements for each type fuel were determined. Table 5.2 gives the results of these calculations. The list of radioisotopes generated from the ORIGEN 2 calculations are based on the following criteria:

1. All isotopes from a list of 270 elements that could have a potential to contribute 1 mrem from inhalation and ingestion are considered.

2. Once the isotopes were selected, those that contribute 99.9 percent of total health hazard were chosen.

3. Isotopes such as ${ }^{85} \mathrm{Kr},{ }^{235} \mathrm{U}$, and ${ }^{238} \mathrm{U}$ were included as historically significant isotopes, although they do not meet the above criteria.

Table 5.2 Bounding Radionuclide Inventories per Element for Selected Fuel Categories (Curies)

\begin{tabular}{|l|c|c|c|c|}
\hline \multirow{2}{*}{ Isotope } & \multicolumn{4}{c|}{ Fuel Category } \\
\cline { 2 - 5 } & BR-2 & RHF & NRU & TRIGA \\
\hline Tritium & 2.40 & 37 & 3.95 & 0.328 \\
\hline Krypton 85 & 68.7 & 1,070 & 113 & 9.10 \\
\hline Strontium 89 & 1,133 & 17,600 & 405 & 68.8 \\
\hline Strontium 90 & 578 & 8,930 & 967 & 79 \\
\hline Yttrium 90 & 578 & 8,930 & 967 & 79 \\
\hline Yttrium 91 & 2030 & 31,400 & 842 & 115 \\
\hline Zirconium 95 & 2,972 & 46,300 & 1,410 & 163 \\
\hline Niobium 95 & 6,111 & 94,900 & 3,060 & 320 \\
\hline Ruthenium 103 & 247 & 3,770 & 60.0 & 21.1 \\
\hline Rhodium 103m & 247 & 3,770 & 60.0 & 21.1 \\
\hline Ruthenium 106 & 597 & 9,160 & 767 & 63.5 \\
\hline Rhodium 106m & 597 & 9,160 & 767 & 63.5 \\
\hline
\end{tabular}




\begin{tabular}{|l|c|c|c|c|}
\hline \multirow{2}{*}{ Isotope } & \multicolumn{4}{c|}{ Fuel Category } \\
\cline { 2 - 5 } & BR-2 & RHF & NRU & TRIGA \\
\hline Tin 123 & 11.9 & 184 & 10.0 & 0.978 \\
\hline Antimony 125 & 24.7 & 381 & 38.0 & 2.98 \\
\hline Tellurium 125m & 5.89 & 90.6 & 9.21 & 0.718 \\
\hline Tellurium 127m & 24.6 & 382 & 18.4 & 1.40 \\
\hline Tellurium 129m & 5.25 & 79.8 & 0.958 & 0.578 \\
\hline Cesium 134 & 456 & 4,000 & 1,480 & 29.0 \\
\hline Cesium 137 & 572 & 8,870 & 958 & 79.8 \\
\hline Cerium 141 & 159 & 2,440 & 277 & 175 \\
\hline Cerium 144 & 8,667 & 135,000 & 10,600 & 633 \\
\hline Praseodymium 144 & 8,667 & 135,000 & 10,600 & 633 \\
\hline Promethium 147 & 1,342 & 24,600 & 1,240 & 175 \\
\hline Promethium 148m & 2.10 & 29.2 & 0.0583 & 1.17 \\
\hline Europium 154 & 17.2 & 163 & 56.3 & 1.05 \\
\hline Europium 155 & 3.61 & 45.6 & 10.2 & 0.565 \\
\hline Uranium 234 & 0.0000254 & 0.000374 & 0.0000654 & 0.00000453 \\
\hline Uranium 235 & 0.000383 & 0.0109 & 0.000253 & 0.000199 \\
\hline Uranium 238 & 0.00000947 & 0.000206 & 0.00000111 & 0.000163 \\
\hline Plutonium 238 & 1.78 & 10.3 & 11.3 & 0.0760 \\
\hline Plutonium 239 & 0.0511 & 0.0889 & 0.0138 & 0.0138 \\
\hline Plutonium 240 & 0.0333 & 0.421 & 0.0101 & 0.0523 \\
\hline Plutonium 241 & 7.89 & 67.7 & 2.95 & 5.33 \\
\hline Americium 241 & 0.0110 & 0.0967 & 0.00517 & 0.0102 \\
\hline Americium 242m & 0.0000292 & 0.000155 & 0.0000250 & 0.000225 \\
\hline Americium 243 & 0.000120 & 0.00376 & 0.000146 & 0.0000110 \\
\hline Curium 242 & 0.0486 & 0.127 & 0.0429 & 0.131 \\
\hline Curium 244 & 0.0369 & 0.00926 & 0.0113 & 0.000178 \\
\hline Total (Curies) & 35,129 & 546,000 & 34,700 & 2,740 \\
\hline Thermal (Watts) & 147 & 2,250 & 150 & 10.4 \\
\hline
\end{tabular}

\section{Melt-Dilute:}

Analysis of dip samples collected for process control sampling should be adequate for determining the quantities of the 39 radionuclides required by Table 5.1. Additionally, highly precise numbers concerning total fissile species can $b$ determined during the post-treatment characterization stage if deemed necessary. During this characterization stage, the emphasis is on data precision and quality since it will ultimately be provided for further inputs regarding thermal analysis, dose, and performance assessment. Several commercial analytic techniques are available for providing these high precision values such as, gamma-ray spectroscopy, thermal ionization mass spectroscopy, and x-ray fluorescence spectrometry. Additionally, the possibility exist for the ability to perform bounding measurements and calculations such that each melt-grab sample need not be subjected to extensive analytic scrutiny in order to provide quality data for the variety of repository inputs. Ultimately, however, regardless of technique or approach, the melt-dilute post-treatment characterization station must be capable of providing precise values for the required 39 radionuclide species and for the total fissile material content ( $\mathrm{U}$ and $\mathrm{Pu}$ ). 


\section{Direct:}

Direct calculation of the radionuclide content of SNF is based on fuel property data determined during fuel fabrication and the reactor operating history. This approach is preferred because it is sufficiently accurate, relatively inexpensive, and technically straightforward. Direct calculation may not be possible for all FRR older DRR because data is unavailable, incomplete, or inaccurate. Bounding radionuclide inventories per fuel element have been estimated for selected types of FRR fuel, Table 5.2, and are directly applicable to the direct disposal option. Each canister would contain multiple fuel elements, 40 of the MTR design or 64 of the MIT design, for example.

Where fuel fabrication and reactor operating histories are inadequate, the isotope quantities can be provided by a combination of a non-destructive assay and analysis. A detection system is envisioned for detecting and quantifying, as a minimum, the fission products ${ }^{137} \mathrm{Cs}$ and ${ }^{241} \mathrm{Am}$ and the fissile species ${ }^{235} \mathrm{U}$ and

${ }^{239} \mathrm{Pu}$. The balance of the isotope inventory would be assembled through analysis. Other isotope combinations can be used. To provide this information for the direct Al-SNF form, the TSF would have to have the capability of assaying the fission product and fissile species of individual Al-SNF assemblies using an NDA system. A complete set of the quantities of the above isotopes on a per assembly basis within the required accuracy would be provided by data analysis. This may include construction of a bounding reference assembly for a grouping of Al-SNF assemblies.

\subsubsection{Disposability Standard 2.3.21 - Limits on Total Fissile Material in a Disposable Canister**}

In addition to limits on individual radionuclides, there is also a limit on the total fissile material contained in individual disposable canisters. Repository preclosure safety and acceptable longterm performance require limits on total fissile material in SNF assemblies. In lieu of measurements, initial enrichment, burn-up histories, and time since reactor discharge will be used to calculate total fissile material. This disposability standard establishes limits on total fissile material and defines the methodology to be used to calculate total fissile material, including the use of burn-up credit.

There are no limits on the total fissile material in disposable containers based on current waste package and performance assessment analyses. Analyses are ongoing to establish a quantified disposability standard for limits on total fissile material.

The melt dilute and direct forms will be assessed once this Disposability Standard has been established.

\subsubsection{Disposability Standard 2.3.22 - Limits on Disposable Canister Criticality Potential}

Canisters placed into disposal containers without being opened must comply with criticality controls that are part of the waste package design. This design is based on the assumption that over the life of the repository there will be substantial changes to the wastes, canisters, and repository environment that can degrade existing criticality controls. This disposability standard establishes limits on criticality potential through the use of an effective neutron multiplication factor ( $\left.\mathrm{k}_{\mathrm{eff}}\right)$ and defines the methodology and assumptions to be used in calculating $\mathrm{k}_{\mathrm{eff}}$ 
Canistered SNF entering the MGDS shall be shown to have a calculated $k_{\text {eff }}$ of 0.95 or less, after allowance for bias in calculation methods and uncertainty in the empirical data used to validate the method of calculation (Disposal Criticality Analysis Methodology Technical report B000000001717-5705-00020 REV 01 (CRWMS M\&O 1996e)). The following conditions are assumed:

- All canister basket structure (other than components made from titanium, zircaloy, or other extremely corrosion resistant materials) have collapsed and degraded to corrosion products.

- All supplemental neutron absorber materials, except hafnium, have degraded and are no longer part of the Waste Package.

- Assembly hardware has degraded and all fuel assemblies are touching in an optimum reactivity condition (applies to corrosion resistant zircaloy clad fuel)

- SNF reactivity has increased to the peak levels in the early years after reactor discharge

\section{Melt-Dilute:}

A criticality analysis of the Melt-Dilute SNF form was carried out by WSMS using the KENO-VI computer code [13]. The study covered degradation of the MD SNF form within an intact canister with several initial quantities of ingot in the canister. With the free volume of the canister filled with water, the reactivity was calculated as the ingot material eroded and became suspended in the water. The volume of material eroded was increased until the maximum $\mathrm{k}_{\mathrm{eff}}$ was found. The process was repeated for uranium enriched to 10,15 , and $20 \%{ }^{235} \mathrm{U}$. The results indicate that the $\mathrm{MD}$ form will require the addition of poison materials in the event that the canister is not sufficiently filled to exclude moderator to a degree that would preclude achieving criticality. The amount of poison that would be required to maintain a sub-critical condition will depend on the free volume in the canister and on the enrichment. A sub-critical condition can be attained without the addition of poison materials for the enrichment and free volume conditions given in Table 5.3. Further analysis is planned for the situation of degraded SNF and HLW within the waste package.

Table 5.3 Parameters to Preclude Criticality for the Melt-Dilute Form without Poisons

\begin{tabular}{|c|c|}
\hline${ }^{235}$ U Enrichment & Maximum Free Volume (\%) \\
\hline 20 & 10 \\
\hline 15 & 40 \\
\hline 10 & Does not achieve criticality \\
\hline
\end{tabular}

\section{Direct:}

Analyses of both intact and degraded direct SNF form indicate that neutron poisons are required to maintain criticality control within the co-disposal waste package during the life of the repository. Criticality analysis of the Direct Al-SNF form has been undertaken by OCRWM and is divided into three phases. Phase I considered a breached and flooded waste package containing relatively intact canisters and internal basket and support structures [14]. Phase II considered degradation of the Al-SNF and structures internal to the co-disposal waste package including $\mathrm{HLW}$, canisters, and criticality control material [15]. Phase III 
will consider the possibility of external criticality which could arise from flow of water carrying fissile material out of the waste package. Analyses of Phases I and II are complete. Recommendations have been made for poison materials based on results of Phases I and II.

Phase I - Two DOE-SNF fuel types were analyzed: high-enrichment MIT reactor fuel and the medium-enrichment ORR fuel. MIT and ORR fuel types were chosen to represent near-bounding conditions for the wide variations found in Al-based research reactor fuels [14]. The MIT and ORR fuels have $93.5 \mathrm{wt} \%{ }^{23.5} \mathrm{U}$ and $20.56 \mathrm{wt} \%{ }^{235} \mathrm{U}$, respectively. Criticality calculations were performed for intact fuel contained within a disposable canister under repository conditions. The MCNP4A computer code calculates the effective multiplication factor $\left(k_{\text {eff }}\right)$ for a variety of geometric configurations with neutron cross sections for elements and isotopes described in ENDF-B/V. Several criticality analyses were performed in order to establish the quantity of stainless steel/boron alloy needed to ensure subcritical conditions if the fuel degrades within an intact basket. Criticality control was maintained within a canister of Nitronic-50 (XM-19) stainless steel with an internal basket structure fabricated from borated stainless steel.

Phase II - Ranges of environmental parameters and failure mechanisms were evaluated to develop degradation scenarios for criticality analysis [15]. The chemistry/geochemistry of the system was analyzed as a function of time with the $\mathrm{EQ} 3 / 6$ program with successive runs linked to simulate water dripping into and flowing out of the waste package. The following degradation sequence is assumed: water drips on the waste package; corrosion and breach of the waste package with accumulation of water within the waste package; corrosion of the stainless steel HLW and SNF canisters; degradation of HLW glass to form clay; degradation of Al-SNF with or after the HLW glass; degradation of canister basket material including criticality control material; flushing of the solution from the waste package by dripping water which may remove neutronically significant elements such as boron from the waste package. If the fuel canister is breached while the HLW is degrading most of the uranium could dissolve in the high $\mathrm{pH}$ $(>10)$ water and be flushed out of the waste package. This scenario does not produce criticality. If the fuel canister is penetrated after the HLW glass has been degraded and the $\mathrm{pH}$ has returned to near neutral the uranium is not very soluble and would remain in the canister or waste package. Three configurations are possible: (1) degraded fuel in the intact or degraded basket within the fuel canister, (2) a layer of hydrated aluminum, uranium, and iron oxides from the fuel on top of the clay formed by the degraded HLW glass, (3) degraded products from the fuel mixed with fractions of the degraded HLW glass. Criticality analyses were made for parametric variations of these three configurations. Configurations 2 and 3 are less reactive than configuration 1.

\subsubsection{Disposabilitv Standard 2.3.23 - Limits on Organic Materials in Canistered Spent Nuclear Fuel**}

Organic materials may accelerate corrosion by providing nutrients for microbes, may form soluble species with radionuclides, may adversely affect hydrogen ion concentrations, or may assist in formation of radionuclide colloids. It is recognized that these organics may exist in the spent fuel or be a contaminant on some assembly surface, or may be introduced into the canister either during canister cleaning (e.g., degreasing) or by spilling / dripping of lubricants or fluids used in 
processing and handling equipment. Repository post-closure performance requires that strict limits be placed on organics in the wastes accepted by the MGDS.

There are regulatory requirements in addition to the performance-based limits on organics. Canisters of SNF entering the MGDS shall not have a characteristic of or be listed as hazardous waste as identified in 40 CFR Part 261, state of Nevada regulations, or state of generation hazardous waste regulations.

Disposable canisters entering the MGDS shall contain no organics at levels that will compromise the repository's ability to achieve long term performance objectives. No component of the canister shall be made of organic material. Disposable canisters shall be excluded from the MGDS if their contents exhibit RCRA hazardous waste characteristics of ignitability, reactivity, corrosivity, or toxicity, or are listed as hazardous waste as defined in 40 CFR 261, Subpart C; is classified as hazardous waste according to state of Nevada regulations (NAC 444); or is considered hazardous waste in the state of generation. Disposable canisters containing TSCA regulated substances, listed in 40 CFR Parts 700-799, at levels such that the wastes must be reported to the EPA and controlled under any provision in 40 CFR 700-799 or Nevada Administrative Code, shall not be accepted by the MGDS without documentation that wastes are no longer regulated under TSCA. For PCBs, no disposable canisters shall be accepted into the MGDS with PCB levels $>50 \mathrm{ppm}$.

\section{Melt-Dilute:}

Operating and inspection procedures for the TSF would be established to ensure that organic materials were not entrained within the disposable canisters. If needed analytical techniques could be developed to ensure compliance with the future Disposability Standard.

\section{Direct:}

See above.

\subsubsection{Thermal, Radiation, and Pressurization Standards for Canistered Waste}

\subsubsection{Disposability Standard 2.4.20 - Limits on Total Thermal Output for Disposable Canisters}

Thermal response within the loaded waste package and the combined effect of emplaced waste packages on the repository horizon require that a limit be imposed on the total thermal output of the waste package. Thermal output limits on canisters ensure that waste packages loaded with these canisters will not exceed the corresponding limits required of the entire waste package.

No disposable single-element SNF canister shall have a thermal output in excess of 1500 watts at the time of shipment to the MGDS. Multi-element canister thermal outputs are addressed in Disposability Standard 2.4.21.

\section{Melt-Dilute:}

Bounding decay heat source estimates for canisters filled with melt-dilute ingot to 75 or $90 \%$ of the canister volume are 569 and 681 watts, respectively,

\section{Direct:}

Bounding and nominal decay heat source estimates for canisters for direct codisposal are 549 and 258 watts, respectively, well within the 1500 watt limit for a single element canister [16]. 


\subsubsection{Disposability Standard 2.4.21 - Limits on Disposable Multi-Element Canister Thermal Design}

Multi-element canisters must not exceed prescribed peak temperature limits for the SNF cladding to ensure the integrity of the SNF cladding and other waste package materials and to meet requirements for the repository engineered barrier system. The cladding temperature for SNF assemblies placed in disposable canisters must not exceed $350^{\circ} \mathrm{C}$. This shall be shown through calculation to be achievable over 1000 years with the following inputs and assumptions:

Decay heat assumed in the calculation shall be calculated using decay heat generation curves appropriate for the specific SNF in the canister.

Temperatures at the canister surface should be assumed to be as follows, with "Year Zero" defined as the time the canister leaves the waste custodian site.

\begin{tabular}{lc} 
Year & Temperature, ${ }^{\circ} \mathbf{C}$ \\
\hline $0-1$ & 150 \\
$1-5$ & 175 \\
$5-50$ & 190 \\
$>50$ & 200
\end{tabular}

\section{Thermal Analysis of Codisposal Waste Packages with Al-SNF}

A thermal analysis methodology was developed to calculate peak temperatures and temperature profiles of Al-SNF in the DOE SNF canister within a co-disposal waste package [17]. A twodimensional baseline model with conduction and radiation coupled heat transfer was developed to evaluate the thermal performance over a range of possible heat loads and boundary conditions, Figure 5.1. Natural convection of the backfill gas was neglected in the baseline model, but was included in a detailed model. The detailed model was applied to the direct codisposal waste package to identify the dominant cooling mechanism for the present waste package configuration, to investigate physical cooling mechanisms in detail, and to estimate the conservatism imbedded in the baseline model. Assumptions and cases in the analysis were: helium or air as backfill gas in the canister and waste package; upper bound or nominal decay heat sources for the SNF and HLW; a repository ambient temperature of $100^{\circ} \mathrm{C}$ or $150^{\circ} \mathrm{C}$; cooling times of 10,20 , and 60 years; intact canister and waste package internal structures for direct co-disposal; and placement of the waste package at the center of the drift tunnel.

\section{Melt-Dilute:}

Although the melt-dilute form does not have a "cladding", but is a solid mass, the temperature limit of $350^{\circ} \mathrm{C}$ may be taken to apply to any point within the canister and SNF form. The analyses assumed an SNF canister filled to $75 \%$ or to $90 \%$ of the canister volume with aluminum-uranium alloy ingots. Each ingot was eutectic composition, $13.2 \%$ uranium, with less than $20 \%$ enriched U-235. Heat loads assumed that all of the krypton and $80 \%$ of the cesium had been removed during the melt-dilute process. Waste package temperature profiles based on upper bound heat sources and $75 \%$ volume fill, Figure 5.2, show that the maximum temperature is below $350^{\circ} \mathrm{C}$ even with a canister temperature above $200^{\circ} \mathrm{C}$ at time zero [17]. The peak temperature for an air filled WP is $347^{\circ} \mathrm{C}$. A parametric analysis is underway to evaluate other variations on fill volume and ingot composition. 


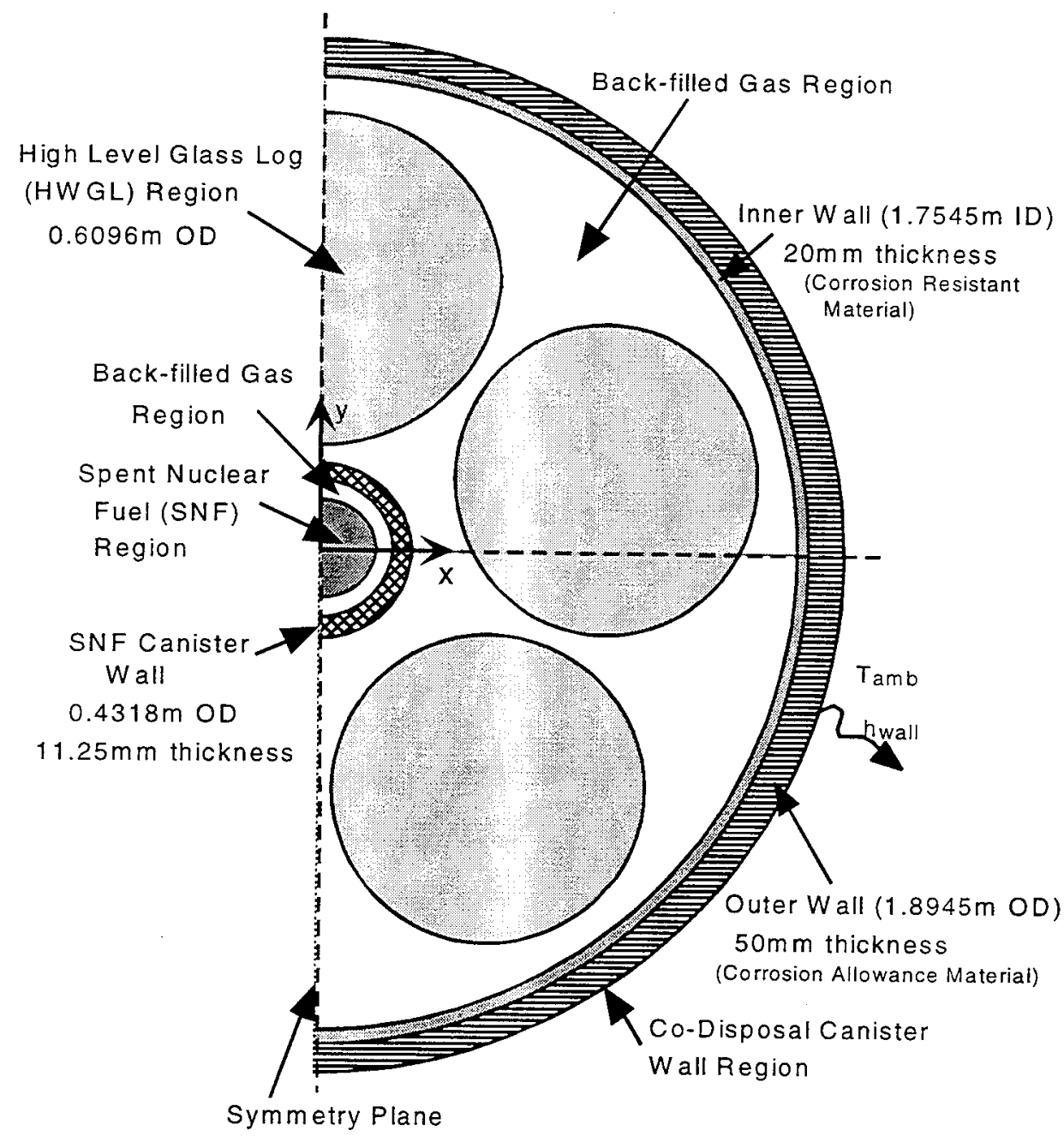

Figure 5.1 Thermal Modeling of Codisposal SNF Waste Package in a Geological Repository

\section{Direct:}

Analysis of the direct form assumed a total of 64 standard MTR type Al-SNF fuel assemblies some with highly enriched uranium within a DOE SNF canister.

Present concepts call for the canister and waste package to be backfilled with helium. Waste package temperature profiles based on the baseline model with upper bound heat sources, Figure 5.3, show that the maximum temperature is below $350^{\circ} \mathrm{C}$ even with a canister temperature above $200^{\circ} \mathrm{C}$ at time zero [17]. Centerline temperature distributions for the baseline model and the detailed model with helium cover gas are both shown in Figure 5.4. 

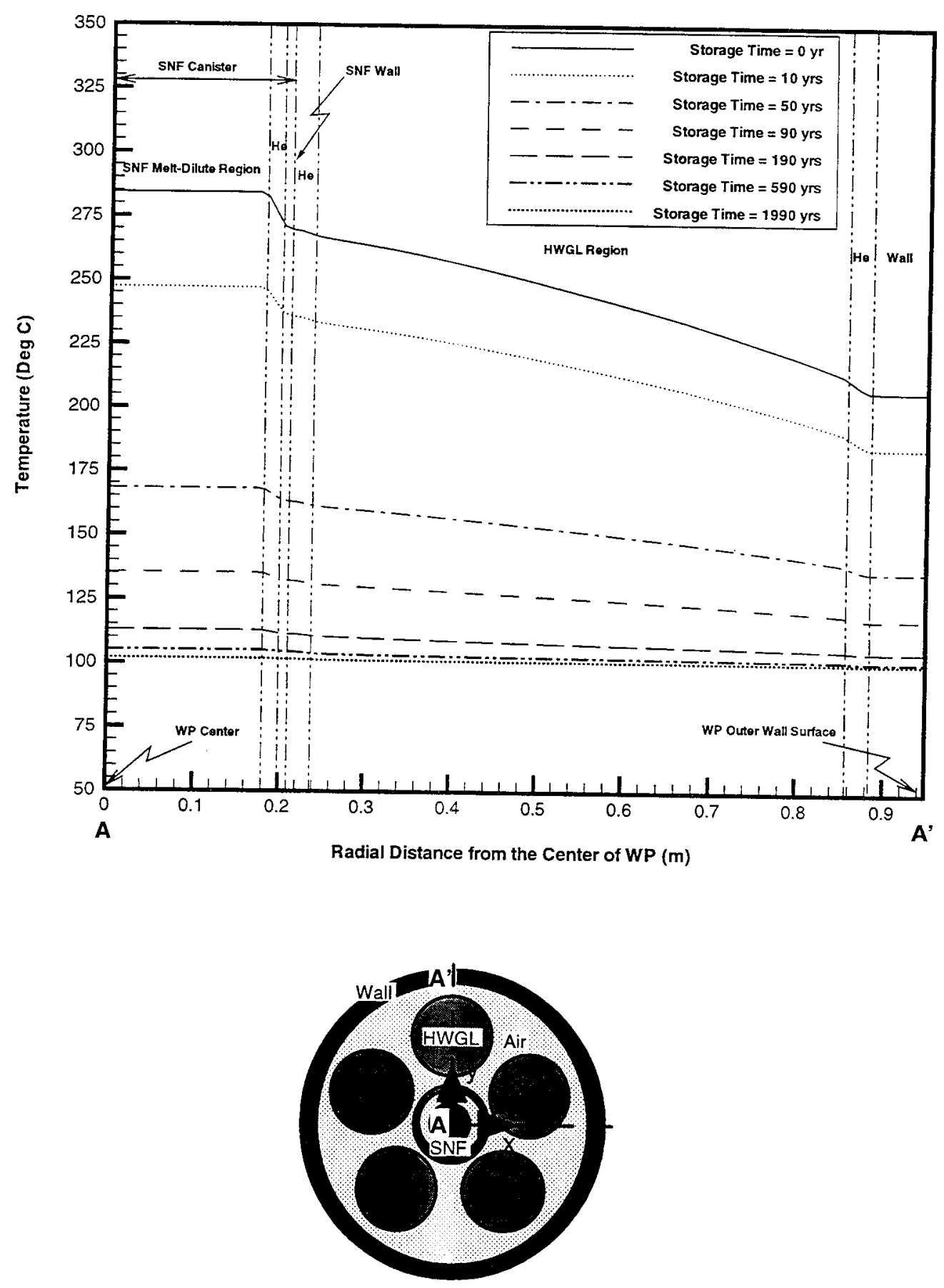

Figure 5.2 He-cooled $75 \%$ volume melt-dilute codisposal WP temperature distribution for various storage times based on the baseline model 

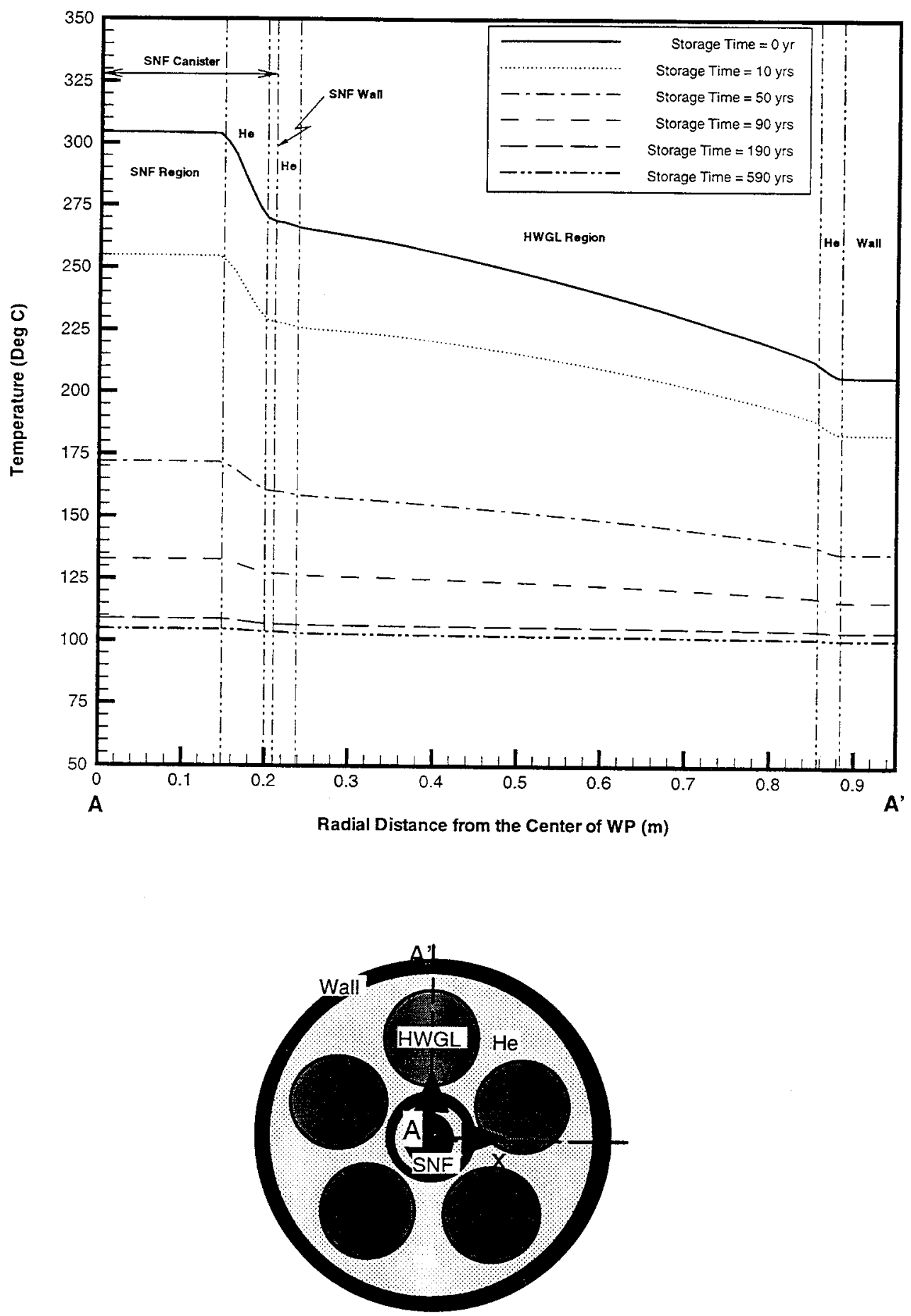

Figure 5.3 He-cooled direct codisposal WP temperature distribution for various storage times based on baseline model with bounding SNF decay heat source. 

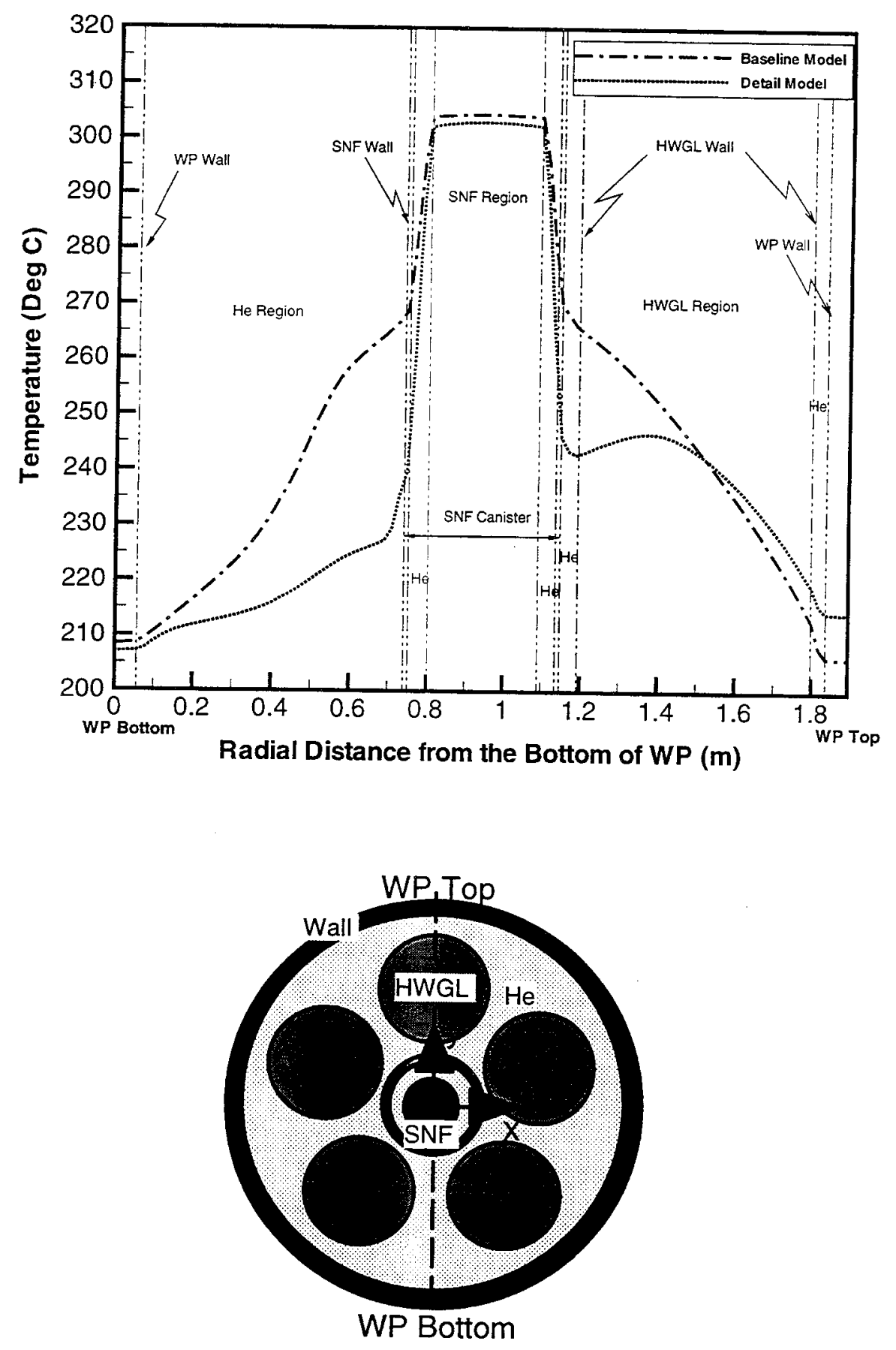

Figure 5.4 Comparison of centerline temperature distributions based on the baseline model and the detailed model for helium-cooled direct codisposal WP with bounding decay heat source. 


\subsubsection{Disposability Standard 2.4.22 - Limits on Disposable Canister Surface Contamination}

The surface contamination on disposable canisters received at the MGDS should be minimized in a manner consistent with ALARA practices. The limits on surface contamination specified in this standard are adapted from the requirements of 49 CFR 173.443 that apply to casks. The level of non-fixed (removable) radioactive contamination on external disposable canister surfaces at the time of canister loading into the cask shall be ALARA, but shall not exceed $220 \mathrm{dpm} / 100 \mathrm{~cm}^{2}$ for alpha emitting radionuclides and $2200 \mathrm{dpm} / \mathrm{cm}^{2}$ for beta and gamma emitting radionuclides on absorbent material that has been wiped, using moderate pressure, over a representative $300 \mathrm{~cm}^{2}$ surface area of the canister.

\section{Melt-Dilute:}

Provisions for decontamination together with operating and inspection procedures for the TSF would be established to ensure compliance with this Disposability Standard.

\section{Direct:}

See above.

\subsubsection{Disposability Standard 2.4.23 - Provisions for Canister Internal Pressure**}

Sealed disposable canisters arriving at the MGDS must not be over pressurized in order to be safely handled in the MGDS surface facility. Disposable canisters shall have a design pressure of 50 psig. After closure the sealed disposable canister shall neither contain nor generate free gases other than air, inert cover gas, and radiogenic gases. These gases shall have a combined internal pressure not to exceed $150 \%$ of the nominal canister or transportation cask design pressure over the entire range of projected canister temperatures. The internal pressure shall not exceed $22 \mathrm{psig}$ $(150 \mathrm{kPa})$ unless otherwise specified in the NRC approved Certificate of Compliance for the transportation cask, in which case the internal pressure shall not exceed that specified in the Certificate of Compliance.

As written, this Disposability Standard appears to be inconsistent with Disposability Standard 2.1.22 which allows limited amounts of water and other free liquids which would generate vapors that are not air, inert cover gas, or radiogenic gas.

\section{Melt-Dilute:}

Current plans for the TSF include having the capability of evacuating the disposable canisters and backfilling with helium to 1.5 atmospheres pressure (approximately $7.5 \mathrm{psig}$ ) which is within the limit of the standard. The helium overpressure facilitates leak detectability from the canisters.

\section{Direct:}

See above.

\subsubsection{Disposability Standard 2.4.24 - Limits on Disposable Canister Leak Rates}

Sealed disposable canisters arriving at the MGDS will be required to demonstrate that their containment envelope continues to retain its integrity. The disposable canister shall have no detectable leak rate in the outermost cover upon receipt at MGDS. At a minimum, the canister 
shall be leak tested per ANSI - N14.5 at the time of closure and re-evaluated if suspected of leaking at any point thereafter.

\section{Melt-Dilute:}

Standard helium leak detection techniques will be utilized for the fabricated canisters. Disposable canisters will be backfilled with helium before the final seal weld is made.

\section{Direct:}

See above.

\section{$5.2 \quad$ References}

1 Mined Geologic Disposal System draft Disposability Interface Specification B0000000001717-4600-00108 REV 00, draft February 1998.

2 Waste Acceptance System Requirements Document (WASRD), DOE/RW-0351P, Rev. 2, DCN-02A, Washington, D. C., U. S. Department of Energy, Office of Civilian Radioactive Waste Management, E00000000-00811-1708-00001, 1996.

3 H. M. Brooks and R. L. Sindelar, WSRC-MS-98-00452, "Characterization of FRR SNF in Basin and Dry Storage Systems," to be presented at the American Nuclear Society - Third Topical Meeting DOE Spent Nuclear Fuel and Fissile Materials Management, Charleston, South Carolinia, September 8-11, 1998.

4 Interface Control Document for U. S. Department of Energy Spent Nuclear Fuel to the Mined Geologic Disposal System for Mechanical and Envelope Interfaces Between the Department of Energy Offices of Environmental Management and Civilian Radioactive Waste Management, DI Number A000000000-01717-8100-000007, Rev 00 (December 17, 1997).

5 D. W. Vinson, G. R. Caskey, Jr., and R. L. Sindelar, "Evaluation of Neutron Poison Materials for DOE SNF Disposal Systems," to be presented at the American Nuclear Society - Third Topical Meeting DOE Spent Nuclear Fuel and Fissile Materials Management, Charleston, South Carolinia, September 8-11, 1998

6 Kuo-Fu Chen, W. S. Large, and R. L. Sindelar, "Vacuum Drying Tests for Storage of Aluminum Spent Nuclear Fuel," in the proceedings of the 1998 International High-Level Radioactive Waste Management Conference, May 1998; see also WSRC-TR-97-00345.

7 DOE-HDBK-1081-94, "DOE Handbook- Primer on Spontaneous Heating and Pyrophoricity," December 1994, U. S. Department of Energy.

8 SAND96-8206, UC-804, "Uranium Hydride Formation and Properties: A Review with Commentary on Handling and Disposition," S. L. Robinson and G. J. Thomas, Sandia National Laboratories, January 1996.

9 SRT-MTS-94-0045, "The Potential for Pyrophoric Reactions-on Corroded Mark 31 Slugs," M. R. Louthan, Jr., March 22, 1994.

10 "Standard Guide for Pyrophoricity/Combustibility Testing in Support of Pyrophoricity Analyses of Metallic Uranium Spent Nuclear Fuel," draft 8, T. Thorton, ASTM Subcommittee C26.13 Task Group on Metallic Fuels.

11 WSRC-TR-98-00228, Bases for Functional Performance Requirements for a Treatment and Storage Facility for Spent Nuclear Fuel (U), July 1998. 
12 WSRC-TR-98-00218. Functional Performance Requirements for a Proposed Treatment and Storage Facility for Spent Nuclear Fuel (U), July 1998.

13 WSMS-CRT-98-0003 Rev. 0., "Criticality Evaluation of DOE SNF Codisposal Canister with Melt and Dilute MTR Fuel," S. M. Revolinski, Westinghouse Safety Management Solutions (February 27, 1998).

14 A.H.Wells and J.W.Davis. Evaluation of Codisposal Viability for Aluminum-Clad DOEOwned Spent Fuel: Phase 1; Intact Codisposal Canister. DI Number BBA000000-017175705-00011 REV 00, Civilian Radioactive Waste System Management \& Operating Contractor (June 9, 1997).

15 J.W.Davis and P.Gottlieb. Evaluation of Codisposal Viability for Aluminum-Clad DOEOwned Spent Fuel: Phase 2; Intact Codisposal Canister. DI Number BBA000000-017175705-00017 REV 00, Civilian Radioactive Waste System Management \& Operating Contractor (December 15, 1997).

16 WSMS-CRT-97-0016, "Decay Heat Characterization of SRS Research Reactor Fuels," D.C.Losey, February 1998.

17 WSRC-TR-98-00158, "Thermal Analysis of Repository Co-disposal Waste Packages Containing Aluminum Spent Nuclear Fuel (U)," S.Y.Lee and R.L.Sindelar, April 1998. 


\section{APPENDIX A}

\section{A.0 SCOPE OF FUEL AT SRS TO BE DISPOSITIONED}

The SRS is presently consolidating the DOE Al-SNF from foreign and domestic research reactors. A description of these fuels using the best available information is provided in this appendix. The treatment of Al-SNF for ultimate disposition must deal with these fuels. Additional information on these fuels will be obtained through characterizations as discussed in the report.

\section{A.1 Aluminum-Based Spent Nuclear Fuel}

Aluminum-based spent nuclear fuel from research reactors will account for less than $1 \%$ of the total volume of SNF and high level waste that will require disposal in a geologic repository. However, much of the Al-SNF contains HEU with up to $93 \%$ enrichment. The Materials Test Reactor design assembly which is comprised of fuel elements or plates of aluminum-clad, aluminum-uranium alloy fuel is the dominant design (approximately $80 \%$ of total) and fuel material for research reactors. In addition, some reactor fuel assemblies were fabricated from aluminum-uranium silicide alloys or aluminum-uranium oxides. The fuel elements are clad with one of the aluminum alloys 1100,5052 , or 6061 or their foreign equivalents.

\section{A.2 DOE SNF Repository Performance Categories}

The DOE has categorized all of its spent fuel into fifteen categories. These categories were developed based upon fuel composition and characteristics [1]. The primary concern with grouping the spent fuels was assigning every fuel to a category and making certain that all of the spent fuel fit into a category. The total amount of DOE SNF, excepting Sodium bonded spent fuel (Category 14) and Navy spent fuel (Category 15), is approximately 2436 MTHM. This fuel (Categories 1-13) will be distributed among INEEL, Savannah River, and Hanford. Savannah River has responsibility for a total of 24.03 MTHM that includes fuel from Categories 5-7. Savannah River has 3.67 of the 87.93 MTHM comprising Category 5 and all of the fuels in Categories 6 and 7, 8.96 MTHM and 11.40 MTHM, respectively. The categorization of DOE SNF listed in Reference 1 is being re-categorized. The preliminary re-categorization lists Al-SNF as a single category. That is, Categories 5,6, and 7 have been collapsed to one category based on their similar expected performance in the repository.

\section{A.3 SRS Receipts-Al-SNF}

\section{A.3.I Research Reactor Spent Nuclear Fuel Designs (Al-clad SNF Only)}

Research reactors use a number of different fuel designs. These designs can be organized into three broad types: (1) materials and test reactor (MTR)-type design, which includes plate-type designs and concentric tube-type designs, (2) pin-type design, and (3) involute-type design. The following summarizes specific characteristics of the different types of fuel named above.

\section{A.3.1.1 Plate-Type Design}

This type of fuel design is used in the majority of research reactors. The thermal power of these reactors ranges from $1 \mathrm{MW}$ to $50 \mathrm{MW}$. Figure A. land Figure A.2 show typical fuel elements with this type of fuel design. The number of fuel plates in an element varies between 6 and 23, and the initial ${ }^{235} \mathrm{U}$ content varies between $37 \mathrm{~g}$ and $420 \mathrm{~g}$ per element. Similarly, the average burnup of a discharged spent nuclear fuel varies between 15 and 76 percent $\left({ }^{235} \mathrm{U}\right.$ atom percent). The uranium enrichment used this type of fuel varies from just below 20 to 93 percent. 


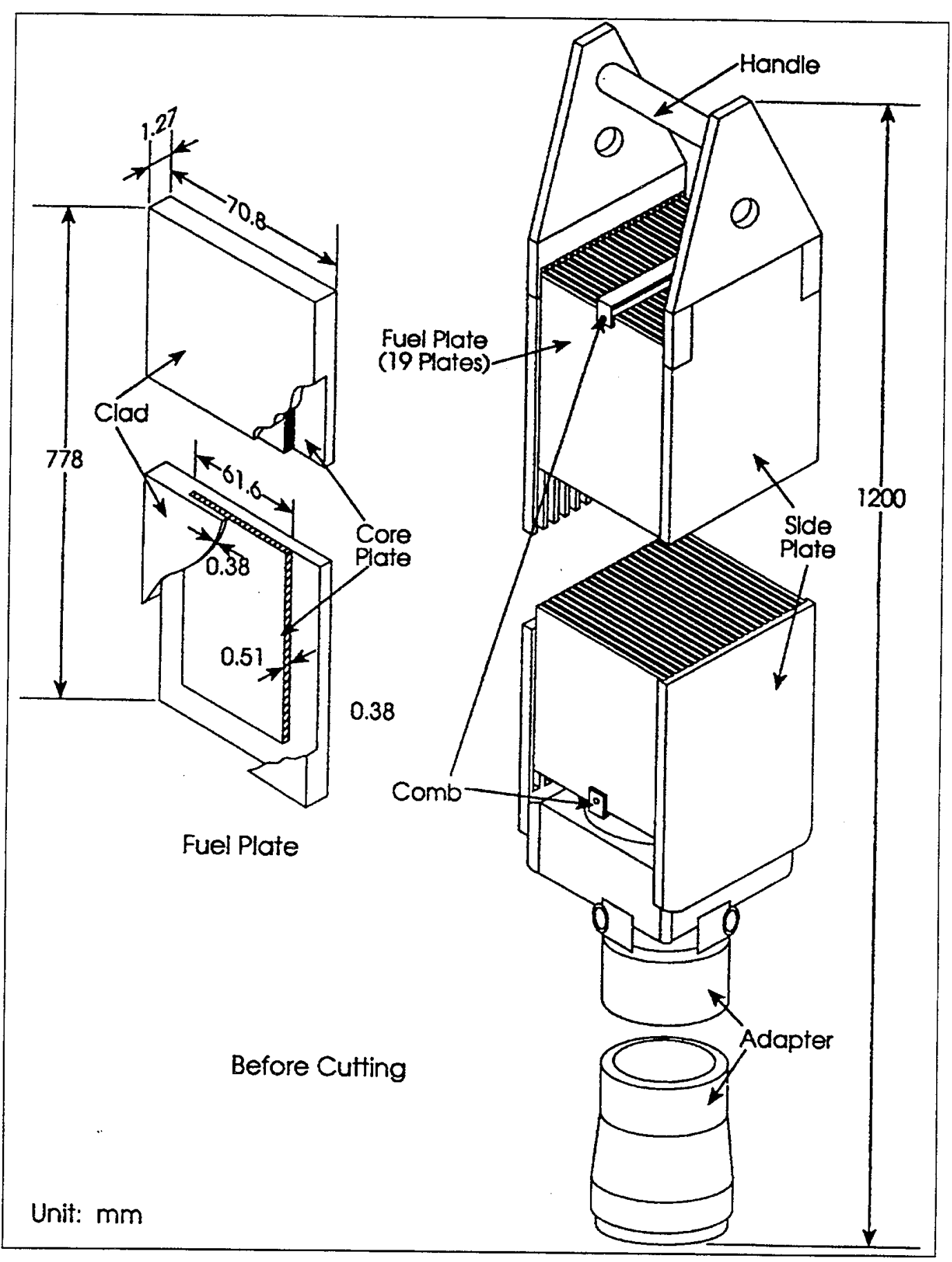

Figure A.1 Typical (Boxed-Type/Flat-Plate) Aluminum-Based Fuẹl Element Schematic 


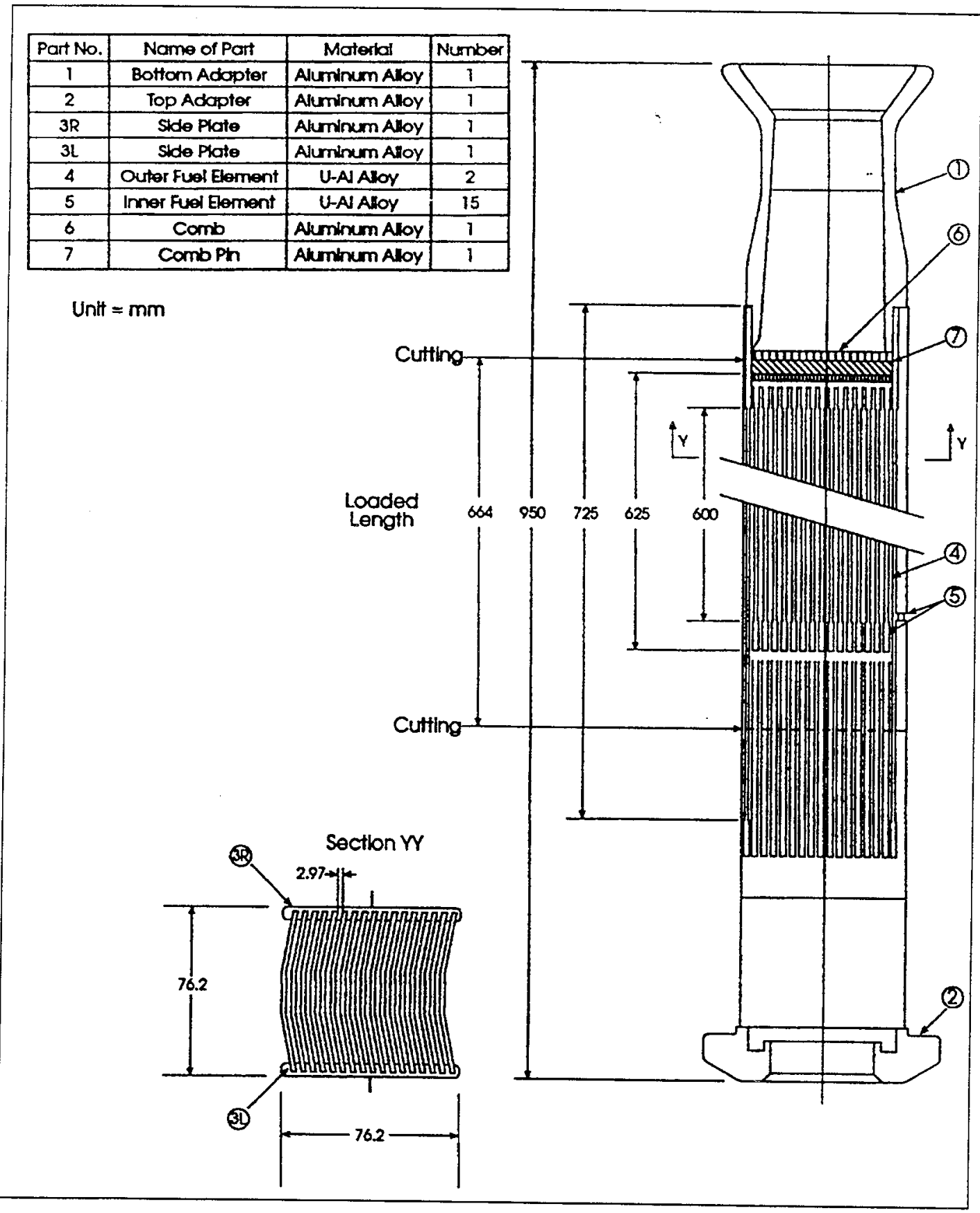

Figure A.2 Typical (Boxed-Type/Curved-Plate) Aluminum-Based Fuel Element Schematic

The following provides additional information on a typical plate-type spent nuclear fuel element that was used in a $50 \mathrm{MW}$ research reactor, as shown in Figure A.1 and in Figure A.2.

The fuel element is made of an alloy of 23 percent by weight of 93 percent-enriched uranium in aluminum with a thin $(0.38 \mathrm{~mm})$ aluminum cladding. Each fuel element contains 19 fuel plates. 


\section{A.3.1.2 Concentric Tube Design}

This type of fuel design is used in four foreign research reactors: Australian (HIFAR), Belgian (BR-2), Japanese (JRR-2) and Danish (DR-3).

The Belgian reactor is a $125 \mathrm{MW}$ reactor, and the other three are each $10 \mathrm{MW}$. Figure A.3 shows a typical fuel element with concentric tube (tubular) fuel design type. The number of fuel tubes in an element varies between four (4) and six (6), and the initial ${ }^{235} \mathrm{U}$ content varies between $150 \mathrm{~g}$ and $400 \mathrm{~g}$ per element. The average burnup of discharged spent nuclear fuels from these reactors ranges between 47 and 55 percent $\left({ }^{235} \mathrm{U}\right.$ atom percent). The uranium enrichment used in this fuel varies from just below 20 to 93 percent.

The following provides additional information on a typical tubular type spent nuclear fuel element (shown in Figure A.3 that was used in a $10 \mathrm{MW}$ reactor).

This fuel element initially contains $220 \mathrm{~g}{ }^{235} \mathrm{U}$, and consists of five (5) concentric fuel tubes. Each tube is made of three curved fuel plates. The fuel is an alloy of uranium in aluminum with a thin $(0.38 \mathrm{~mm})$ aluminum cladding. Five (5) different curved fuel plate width sizes with $1.27 \mathrm{~mm}$ thickness and $625 \mathrm{~mm}$ height are used. The overall outside diameter of the outermost tube is 103 $\mathrm{mm}$.

\section{A.3.1.3 Pin-Type Design}

Three types of foreign research reactors use pin-type design fuel. They are: the Canadian Safe LOW Power critical [K] Experiment (SLOWPOKE) $(20 \mathrm{~kW}$ power); the Canadian NRU (125 MW power), NRX (24 MW power) and South Korean KMRR (30 MW) reactors. Among these reactors, the SLOWPOKE fuel pins are the smallest in size and uranium content.

The SLOWPOKE reactor fuel pins have an outside diameter of $4.73 \mathrm{~mm}$, a length of $220 \mathrm{~mm}$, and contain 93 percent enriched uranium fuels. The ${ }^{235} \mathrm{U}$ content of each pin is $2.8 \mathrm{~g}$. The maximum fuel burnup of discharged spent nuclear fuels is about 2 percent $\left({ }^{235} \mathrm{U}\right.$ atom percent) in 10 to 20 years of reactor operation.

The SLOWPOKE spent nuclear fuel pins are usually bundled together in 10 to 15 pins per bundle. In the past, this fuel was shipped to the Savannah River Site in $50.8-\mathrm{mm}$ outside diameter; $2.9-\mathrm{m}$ long canisters containing between 150 to 160 pins per canister.

The fuel type in the Canadian research reactors consists of clusters of about $3 \mathrm{~m}$ long uranium aluminum alloy fuel pins clad in aluminum. The initial ${ }^{235} \mathrm{U}$ content of each fuel cluster varies between $491 \mathrm{~g}$ and $545 \mathrm{~g}$. The current operating reactor (NRU) uses a fuel element that consists of a cluster of 12 long pins containing $491 \mathrm{~g}$ of ${ }^{235} \mathrm{U}$ per cluster. Each fuel pin has an overall length of $296 \mathrm{~cm}$, and the fuel portion is $274.3 \mathrm{~cm}$ long. The fuel cluster, including the flow tube, is cut to a length of $292.6 \mathrm{~cm}$ before shipment. The average burnup of discharged spent nuclear fuels from a NRU reactor is about 76 percent $\left({ }^{235} \mathrm{U}\right.$ atom percent). Figure A.4 shows a 12-pin cluster NRU fuel element. The fuel in the South Korean research reactor consists of two types of fuel clusters. The first is 18 pins per cluster with an initial ${ }^{235} \mathrm{U}$ content of $248 \mathrm{~g}(8.7 \mathrm{oz})$. The second is 36 pins per cluster with an initial ${ }^{235} \mathrm{U}$ content of $435 \mathrm{~g}(1 \mathrm{lb})$. The expected burnup of a discharged spent nuclear fuel from this reactor is approximately 65 percent $\left({ }^{235} \mathrm{U}\right.$ atom percent). 


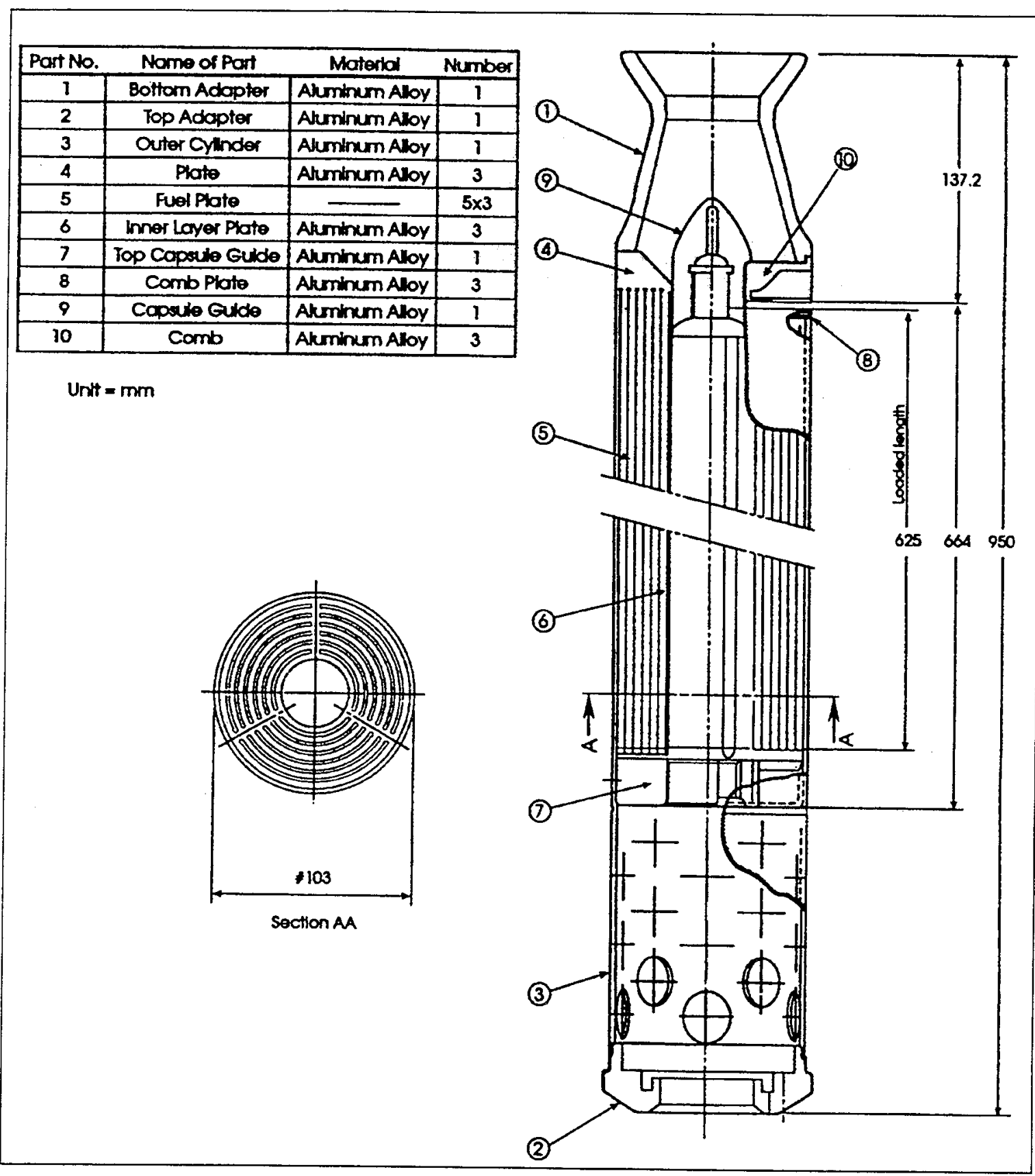

Figure A.3 Typical MTR (Tube-Type) Aluminum-Based Fuel Element Schematic

\section{A.3.1.4 Involute Type Design}

The fuel used in the high flux reactors is an involute-type fuel element. These research reactors consist of a single fuel element. There are currently two reactors of this design anticipated to ship SNF to the SRS. They are the Oak Ridge National Laboratory (ORNL) High Flux Isotope Reactor (100 MW) and the French Reactor à Haut Flux (57 MW). 


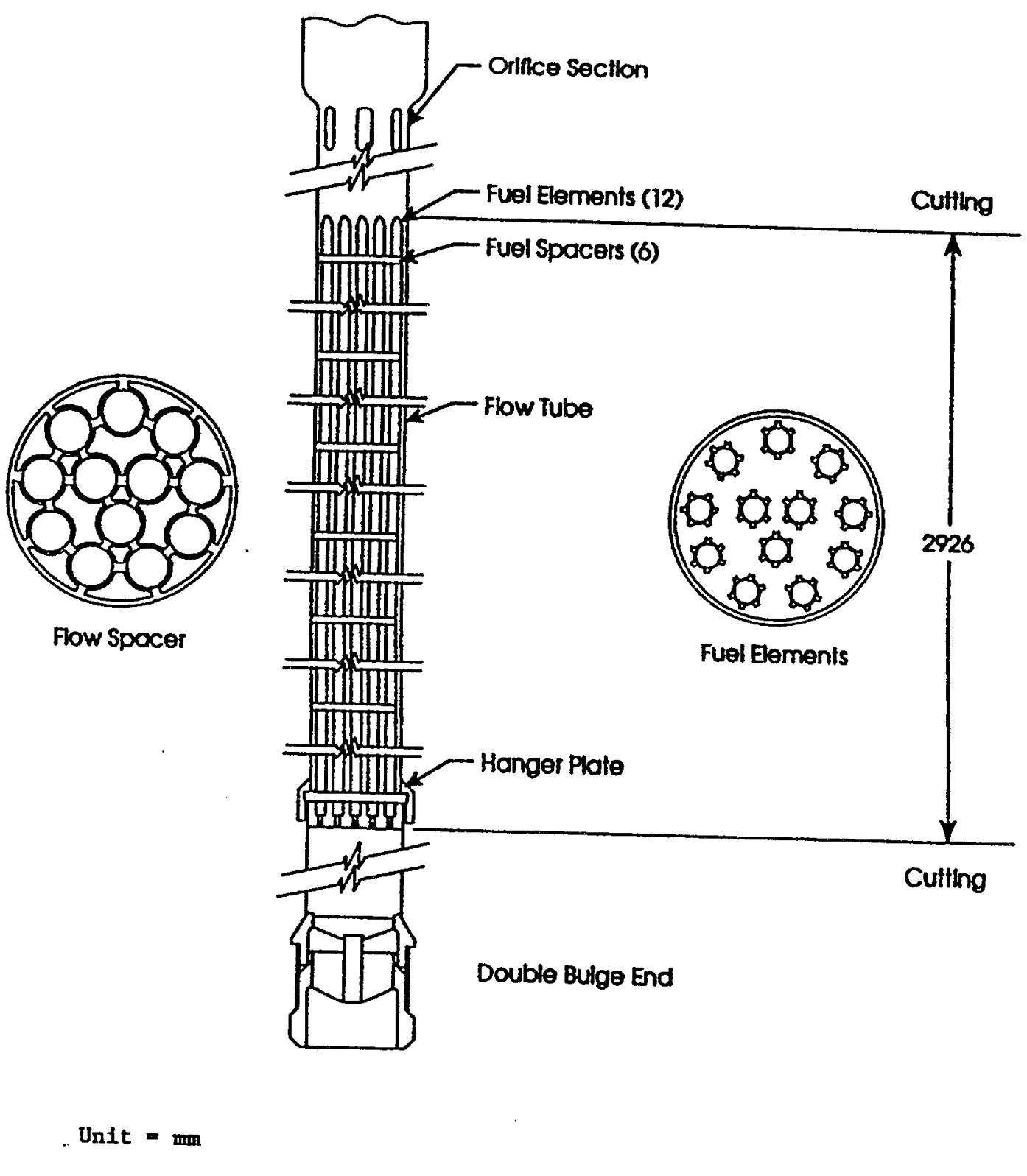

Figure A.4 Typical Pin-Type (Aluminum-Based) Fuel Element Schematic

The RHF fuel element contains $9.2 \mathrm{~kg}$ of uranium, enriched to 93 percent of ${ }^{235} \mathrm{U}$ in 280 involute fuel plates made of uranium aluminum alloy $\left(\mathrm{UAl}_{3}-\mathrm{Al}\right)$, clad in aluminum. The weight of an element is about $100 \mathrm{~kg}$. The fuel is in the annulus of two aluminum tubes: the inner tube has an outside diameter of $274 \mathrm{~mm}$, and the outer tube has an outside diameter of $414 \mathrm{~mm}$. The expected average burnup of a discharged spent nuclear fuel is 36 percent $\left({ }^{235} \mathrm{U}\right.$ atom percent). Figure A.5 shows a schematic drawing of a configuration of annular fuel element similar to that of RHF fuels. 


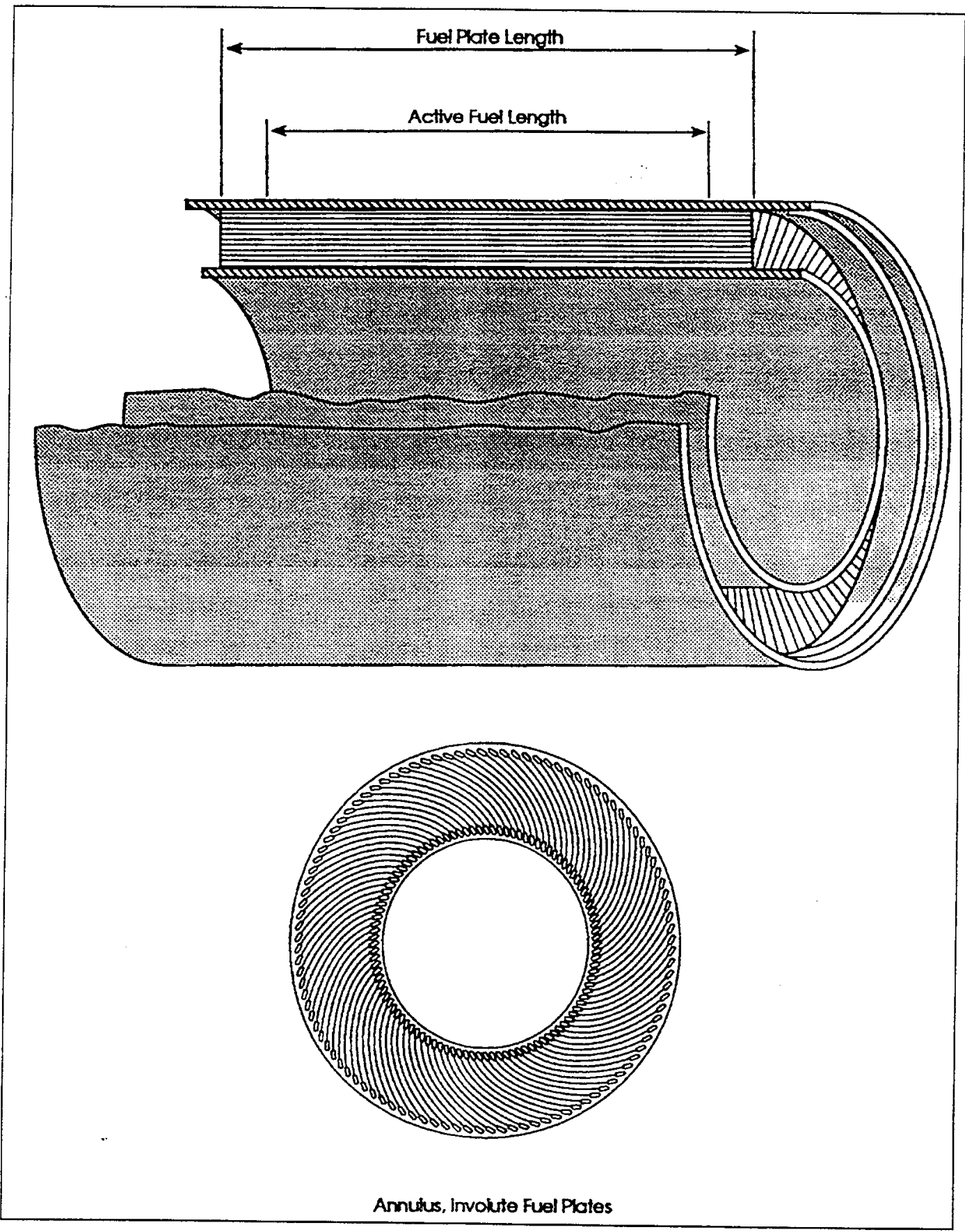

Figure A.5 Typical Involute(1)-Type (Aluminum-Based) Fuel Element Schematic

The HFIR fuel elements contain $10 \mathrm{~kg}$ of Uranium, enriched to $93 \%$ of ${ }^{235} \mathrm{U}$. The element consists of an inner annulus (171 involute fuel plates) and an outer annulus (369 involute fuel plates). The material is uranium oxide - aluminum matrix, clad with aluminum. The total weight of the element is $136 \mathrm{~kg}$. The tube is $80 \mathrm{~cm}$ long with an outer diameter of $43 \mathrm{~cm}$. Figure A.6 shows a schematic drawing of a configuration of a typical HFIR fuel element. 


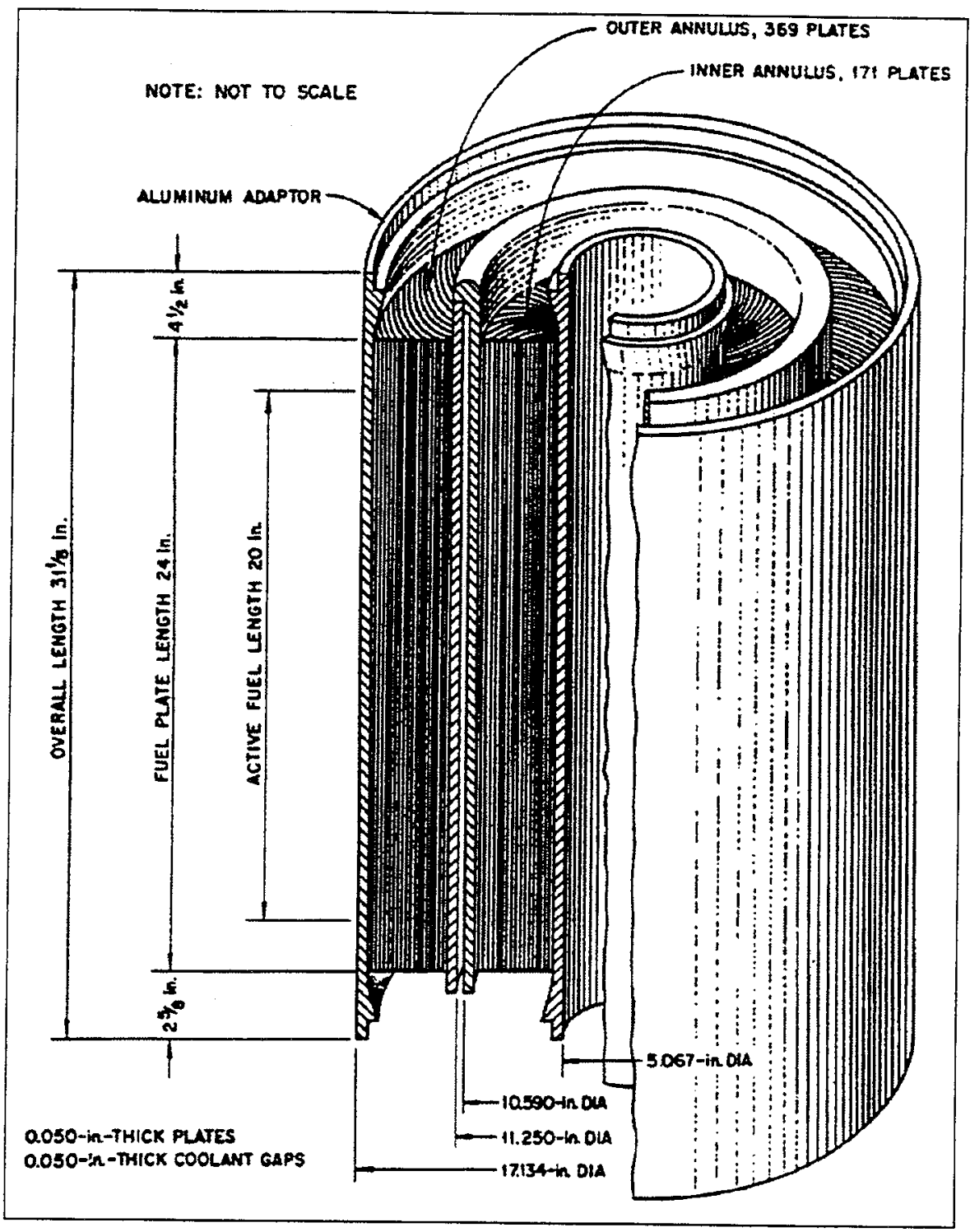

Figure A.6

Typical Involute(2)-Type (Aluminum-Based) Fuel Element Schematic

\section{A.3.1.5 General Purpose Tubes}

SNF elements may be received in SRS General Purpose Tubes, Square Cans, L-Basin Cans, or other aluminum bundling or canisterizing container. Onsite storage basins have utilized General Purpose Tubes to maximize storage space inventory, within radiological limits. The number of SNF elements within each General Purpose Tube may range from one to six, depending on the type and size of element(s). The SNF elements within a General Purpose Tube may be cropped and stacked with appropriate spacer material provided for radiological purposes. WSRC Drawings CCS-L-0962, S4-2-609 and S5-2-6835 represent typical general-purpose tube design(s).

\section{A.3.2 U Oxide/Failed Clad \& Al}

Table A.1, Table A.2, and Table A.3 provide a detailed listing of the current projection of types and quantities of uranium oxide, mixed oxide, and uranium metal fuel materials to be handled by $\mathrm{TSF}$, respectively. The definition of the acronyms in the Reactor/Assembly Description column for 
these tables may be found in the International Atomic Energy Agency (IAEA) Directory of Nuclear Reactors and the IAEA Nuclear Research Reactors in the World. The tables may include some assemblies that are scheduled for reprocessing. The contents of the tables may change as processing is completed.

Table A.1 Uranium Oxide Inventory

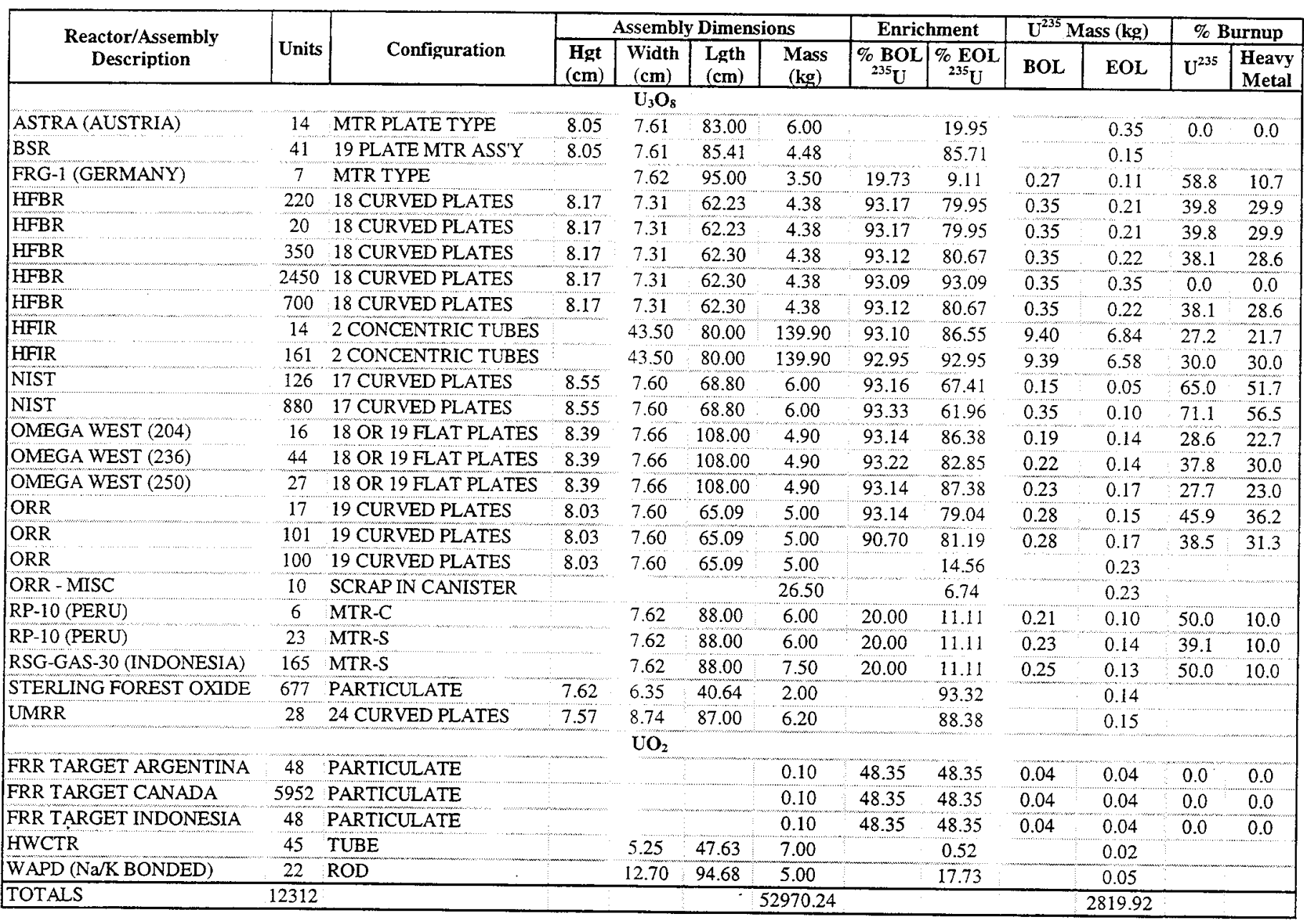


Table A.2 Mixed Oxide Inventory

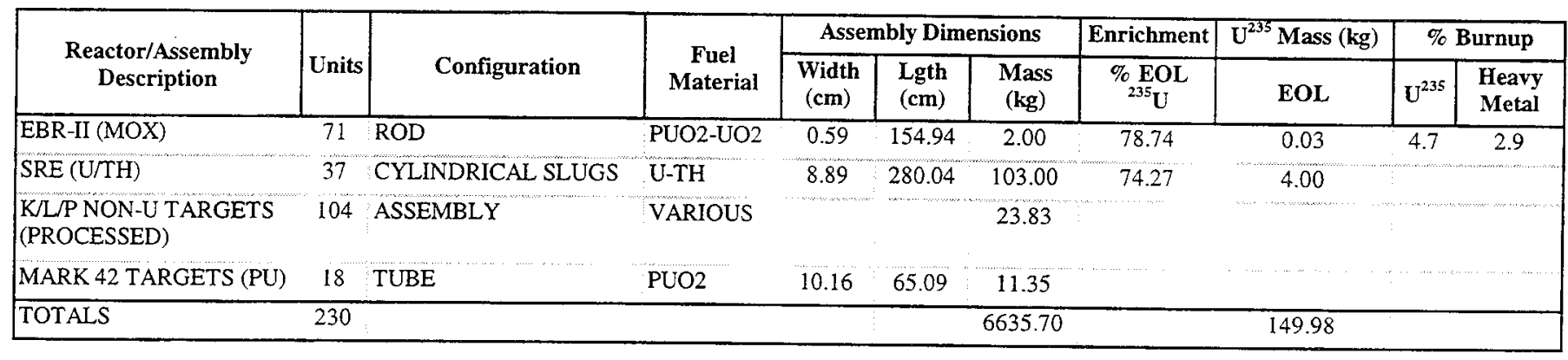

Table A.3 Uranium Metal Inventory

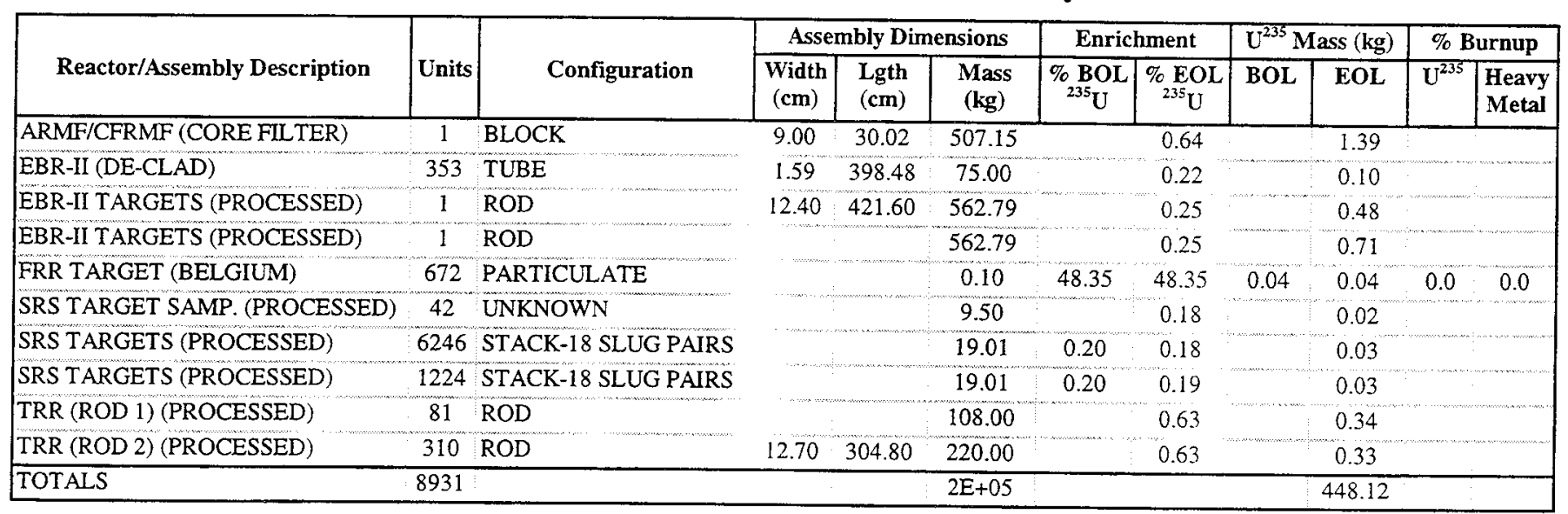

\section{A.3.3 $U A l_{x} / A l$}

Table A.4 provides a detailed listing of the current projection of types and quantities of uranium aluminum fuel materials to be handled by TSF. The definition of the acronyms in the Reactor/Assembly Description column for this table may be found in the IAEA Directory of Nuclear Reactors and the IAEA Nuclear Research Reactors in the World. The table may include some assemblies that are scheduled for reprocessing. The contents of the table may change as processing is completed. 
Table A.4 Uranium/Aluminum Inventory

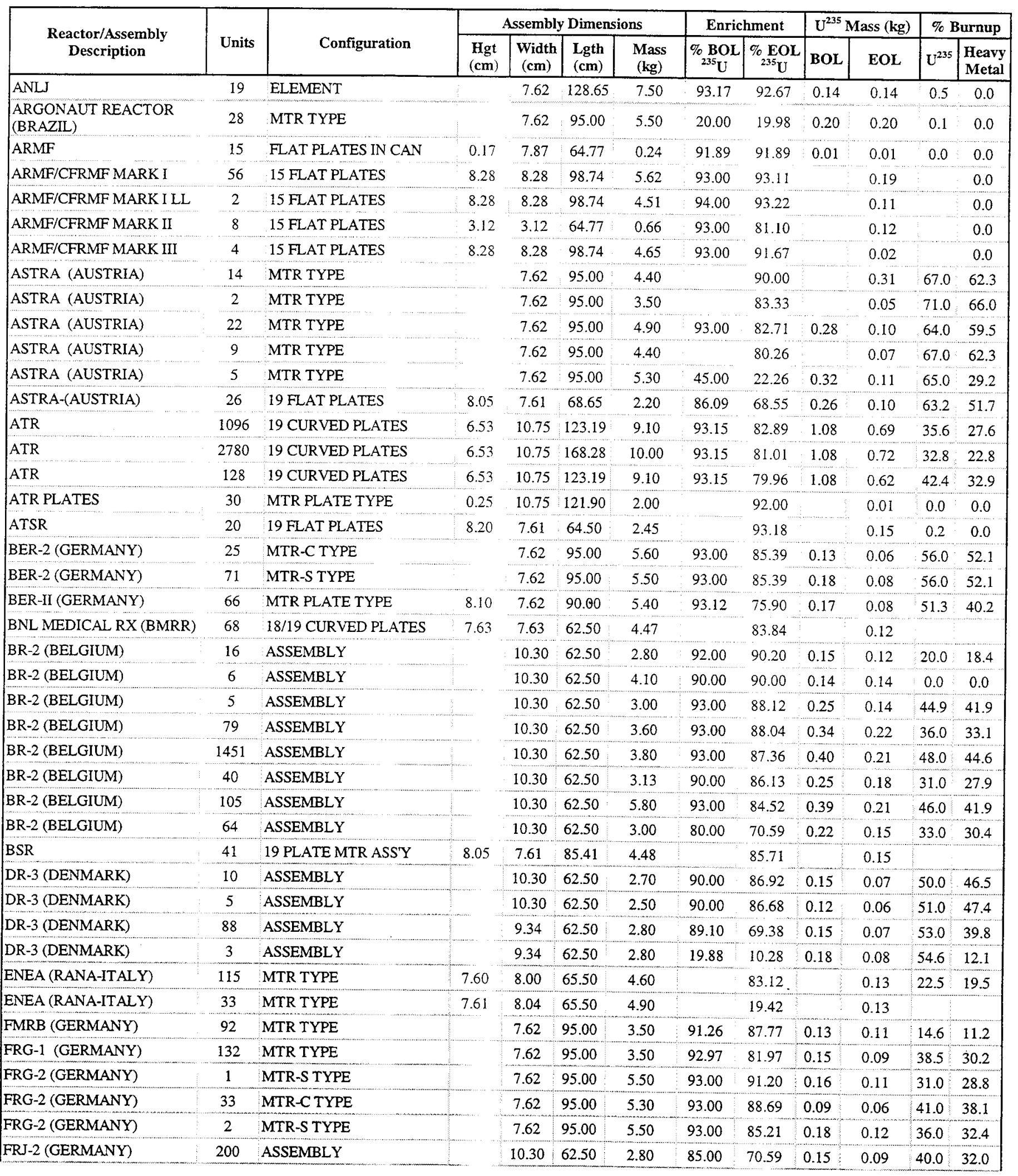




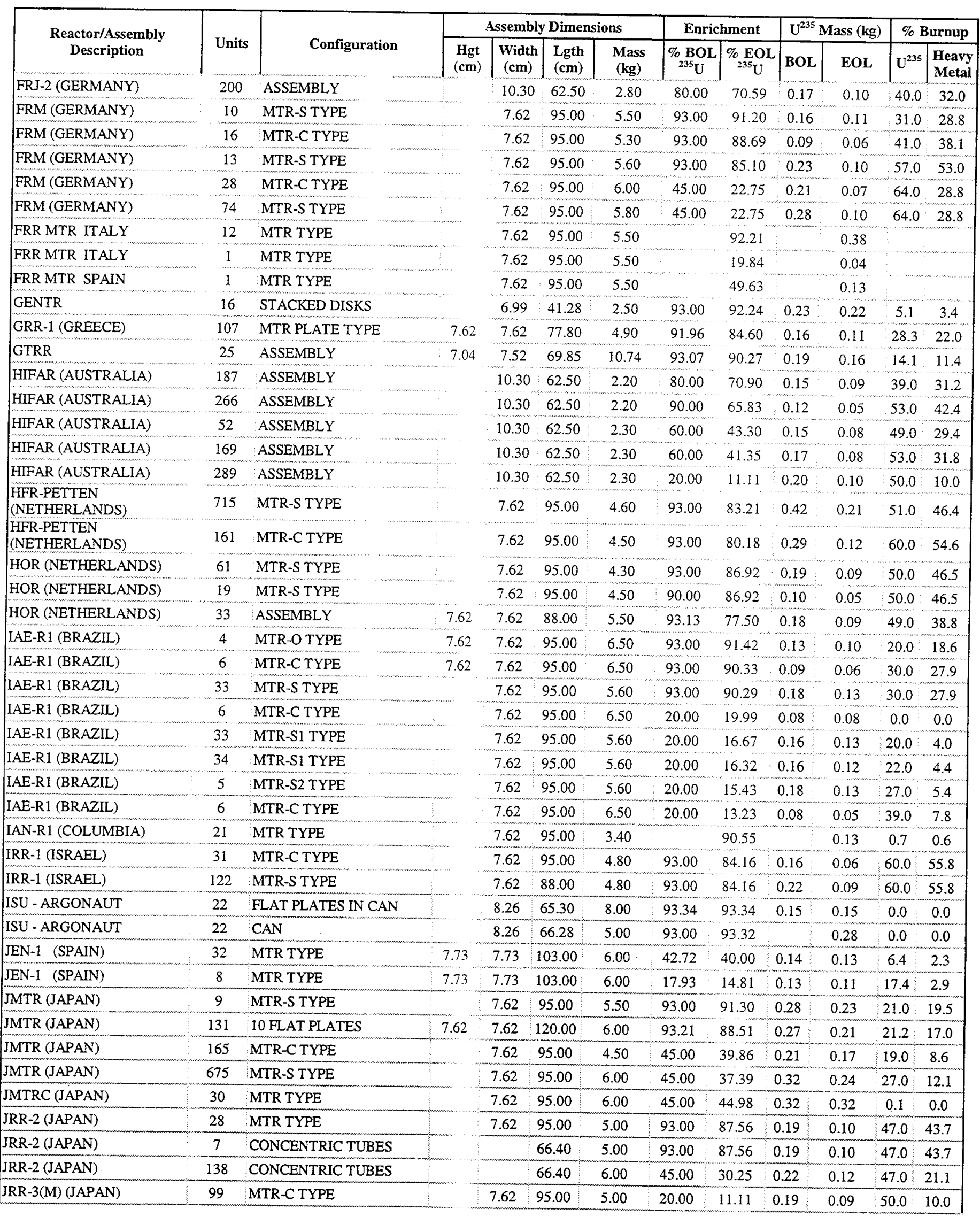




\begin{tabular}{|c|c|c|c|c|c|c|c|c|c|c|c|c|}
\hline \multirow{2}{*}{$\begin{array}{l}\text { Reactor/Assembly } \\
\text { Description }\end{array}$} & \multirow[b]{2}{*}{ Units } & \multirow[b]{2}{*}{ Configuration } & \multicolumn{4}{|c|}{ Assembly Dimensions } & \multicolumn{2}{|c|}{ Enrichment } & \multicolumn{2}{|c|}{$\mathrm{U}^{235}$ Mass $(\mathrm{kg})$} & \multicolumn{2}{|c|}{ \% Burnup } \\
\hline & & & $\begin{array}{l}\mathrm{Hgt} \\
(\mathrm{cm})\end{array}$ & \begin{tabular}{|c|} 
Width \\
$(\mathrm{cm})$
\end{tabular} & \begin{tabular}{|l|} 
Lgth \\
$(\mathrm{cm})$
\end{tabular} & $\begin{array}{c}\text { Mass } \\
(\mathrm{kg})\end{array}$ & ${ }^{\%} \mathbf{B O} \mathbf{B O L}$ & ${ }^{\% \text { EOL }}$ & BOL & EOL & $\mathrm{U}^{235}$ & $\begin{array}{l}\text { Heavy } \\
\text { Metal }\end{array}$ \\
\hline JRR-3(M) (JAPAN) & 506 & MTR-S TYPE & & 7.62 & 95.00 & 8.00 & 20.00 & 11.11 & 0.30 & 0.15 & 50.0 & 10.0 \\
\hline JRR-4 (JAPAN) & 54 & MTR TYPE & & 7.62 & 95.00 & 5.00 & 93.00 & 91.40 & 0.17 & 0.13 & 20.0 & 18.6 \\
\hline KUR (JAPAN) & 54 & MTR-C TYPE & & 7.62 & 95.00 & 4.30 & 93.00 & 91.24 & 0.09 & 0.07 & 22.0 & 20.5 \\
\hline KUR (JAPAN) & 218 & MTR-S TYPE & & 7.62 & 95.00 & 4.60 & 93.00 & 90.98 & 0.18 & 0.14 & 24.0 & 22.3 \\
\hline LFR (NETHERLANDS) & 14 & MTR TYPE & & 7.62 & 95.00 & 5.00 & 93.00 & 92.99 & 0.21 & 0.21 & 0.1 & 0.1 \\
\hline MINERVE (FRANCE) & 32 & MTR TYPE & & 7.62 & 95.00 & 5.00 & 93.00 & 92.99 & 0.25 & 0.25 & 0.0 & 0.0 \\
\hline MIT & 277 & 15 FLAT PLATES & 6.42 & 6.11 & 66.68 & 4.00 & 93.00 & 86.69 & 0.51 & 0.40 & 22.1 & 16.5 \\
\hline MIT & 72 & 15 FLAT PLATES & 6.11 & 6.11 & 66.68 & 4.00 & 93.39 & 83.73 & 0.47 & 0.29 & 39.2 & 32.2 \\
\hline MNR (CANADA) & 23 & MTR-C TYPE & & 7.62 & 95.00 & 3.67 & 90.00 & 89.17 & 0.11 & 0.07 & 38.0 & 35.3 \\
\hline MNR (CANADA) & 53 & MTR-S TYPE & & 7.62 & 95.00 & 3.92 & 93.00 & 89.17 & 0.20 & 0.12 & 38.0 & 35.3 \\
\hline MNR (CANADA) & 21 & MTR-S TYPE & & 7.62 & 95.00 & 3.92 & 93.00 & 89.17 & 0.20 & 0.12 & 38.0 & 35.3 \\
\hline MNR (CANADA) & 41 & MTR TYPE & & 7.62 & 95.00 & 3.92 & 93.07 & 81.35 & 0.18 & 0.11 & 39.7 & 31.0 \\
\hline $\begin{array}{l}\text { MOATA ARGONAUT } \\
\text { (AUSTRALIA) }\end{array}$ & 12 & ASSEMBLY & & 7.62 & 88.00 & 4.30 & 90.00 & 89.99 & 0.25 & 0.25 & 0.1 & 0.1 \\
\hline MRU/WMA (CANADA) & 741 & MULTI-PIN CLUSTER & & & & 4.70 & 93.00 & 71.62 & 0.50 & 0.09 & 81.0 & 75.3 \\
\hline MURR & 32 & 24 CURVED PLATES & 7.75 & 9.14 & 82.55 & 6.38 & 93.50 & 87.47 & 0.73 & 0.60 & 18.3 & 12.9 \\
\hline MURR & 24 & 24 CURVED PLATES & 7.75 & 9.14 & 82.55 & 6.38 & 93.50 & 87.16 & 0.73 & 0.59 & 20.1 & 14.3 \\
\hline MURR & 184 & 24 CURVED PLATES & 7.47 & 8.74 & 87.00 & 6.20 & 93.14 & 83.50 & 0.77 & 0.60 & 22.6 & 17.7 \\
\hline MURR (MTR-SI) & 792 & 24 CURVED PLATES & 7.04 & 14.63 & 82.55 & 6.20 & 93.00 & 90.15 & 0.77 & 0.58 & 25.1 & 22.8 \\
\hline NRCRR (IRAN) & 7 & MTR-C TYPE & & 7.62 & 95.00 & 4.10 & 94.50 & 90.29 & 0.11 & 0.08 & 30.0 & 27.9 \\
\hline NRCRR (IRAN) & 22 & MTR-S TYPE & & 7.62 & 95.00 & 4.10 & 93.00 & 87.00 & 0.20 & 0.14 & 30.0 & 27.9 \\
\hline NRX (CANADA) & 131 & MULTI-PIN CLUSTER & & & & 4.50 & 93.00 & 83.78 & 0.55 & 0.21 & 62.0 & 57.8 \\
\hline OHIO STATE & 24 & 18 FLAT PLATES & & 7.62 & 88.90 & 50.00 & 93.25 & 93.24 & 0.13 & 0.13 & 0.1 & 0.0 \\
\hline ORPHEE (FRANCE) & 148 & MTR-C TYPE & & 7.62 & 95.00 & 8.00 & 93.00 & 90.39 & 0.63 & 0.44 & 30.0 & 27.9 \\
\hline ORPHEE (FRANCE) & 148 & MTR-S TYPE & & 7.62 & 95.00 & 9.00 & 93.00 & 90.39 & 0.84 & 0.59 & 30.0 & 27.9 \\
\hline PARR (PAKISTAN) & 17 & MTR-C TYPE & & 7.62 & 95.00 & 4.10 & 92.00 & 88.20 & 0.11 & 0.07 & 35.0 & 32.2 \\
\hline PARR (PAKISTAN) & 65 & MTR-S TYPE & & 7.62 & 95.00 & 4.10 & 92.00 & 88.20 & 0.20 & 0.13 & 35.0 & 32.2 \\
\hline PRR-1 (PHILIPPIINES) & 20 & MTR TYPE & & 7.62 & 95.00 & 4.10 & 93.00 & 90.10 & 0.16 & 0.12 & 25.0 & 23.2 \\
\hline PRR-1 (PHILIPPIINES) & 30 & MTR TYPE & & 7.62 & 95.00 & 4.50 & 20.00 & 16.68 & 0.14 & 0.11 & 20.0 & 4.0 \\
\hline PTR (CANADA) & 14 & MULTI-PIN CLUSTER & & & & 3.80 & 93.00 & 93.00 & 0.15 & 0.15 & 0.5 & 0.5 \\
\hline PTR (CANADA) & 225 & MULTI-PIN CLUSTER & & & & 4.70 & 93.00 & 76.54 & 0.49 & 0.12 & 76.0 & 70.8 \\
\hline PURDUE UNIVERSITY & 124 & 10 FLAT PLATES & 0.15 & 7.01 & 68.80 & 0.03 & 93.00 & 93.22 & 0.17 & 0.02 & 90.0 & 90.0 \\
\hline R-2 (SWEDEN) & 6 & MTR-C TYPE & & 7.62 & 95.00 & 4.30 & 90.00 & 88.44 & 0.12 & 0.10 & 15.0 & 13.5 \\
\hline R-2 (SWEDEN) & 21 & MTR-S TYPE & & 7.62 & 95.00 & 4.30 & 90.00 & 88.44 & 0.12 & 0.10 & 15.0 & 13.5 \\
\hline R-2 (SWEDEN) & 48 & MTR-C TYPE & & 7.62 & 95.00 & 4.60 & 93.00 & 76.12 & 0.16 & 0.04 & 76.0 & 70.7 \\
\hline R-2 (SWEDEN) & 304 & MTR TYPE & 7.62 & 7.62 & 92.40 & 6.00 & 93.06 & 74.77 & 0.24 & 0.10 & 58.8 & 48.8 \\
\hline RA-3 (ARGENTINA) & 36 & MTR-C TYPE & & 7.62 & 95.00 & 4.30 & 90.00 & 85.40 & 0.15 & 0.10 & 35.0 & 31.5 \\
\hline RA-3 (ARGENTINA) & 144 & MTR-S TYPE & & 7.62 & 95.00 & 4.30 & 90.00 & 85.40 & 0.19 & 0.13 & 35.0 & 31.5 \\
\hline RA-6 (ARGENTINA) & 14 & MTR-C TYPE & & 7.62 & 95.00 & 4.30 & 90.00 & 86.31 & 0.15 & 0.11 & 30.0 & 27.0 \\
\hline RA-6 (ARGENTINA) & 59 & MTR-S TYPE & & 7.62 & 95.00 & 4.30 & 90.00 & 86.31 & 0.19 & 0.14 & 30.0 & 27.0 \\
\hline $\begin{array}{l}\text { RA-O CORDOBA UNIV } \\
\text { (ARGENTINA) }\end{array}$ & 30 & MTR TYPE & & 7.62 & 95.00 & 4.30 & 20.00 & 19.84 & 0.13 & 0.12 & 1.0 & 0.2 \\
\hline RECH-1 (CHILE) & 28 & MTR TYPE & 7.61 & 7.61 & 99.30 & 5.00 & 80.00 & 61.00 & 0.16 & 0.08 & 48.6 & 32.6 \\
\hline RHF (FRANCE) & 86 & ASSEMBLY & & 41.40 & & 110.00 & 90.00 & 88.85 & 8.50 & 5.10 & 40.0 & 37.2 \\
\hline RHF (FRANCE) & 4 & 2 CONCENTRIC TUBES & & 40.64 & 97.00 & 102.00 & 92.97 & 81.44 & 8.58 & 5.19 & 39.4 & 30.9 \\
\hline RINSC & 66 & 18 FLAT PLATES & & 7.62 & 62.50 & 2.00 & 93.14 & 90.55 & 0.12 & 0.11 & 11.6 & 9.1 \\
\hline RP-1 (PORTUGAL) & 3 & MTR-O TYPE & & 7.62 & 95.00 & 4.60 & 20.00 & 17.78 & 0.09 & 0.08 & 11.1 & 0.0 \\
\hline RP-1 (PORTUGAL) & 9 & MTR-C TYPE & & 7.62 & 95.00 & 5.30 & 20.00 & 17.18 & 0.09 & 0.07 & 17.0 & 3.4 \\
\hline
\end{tabular}




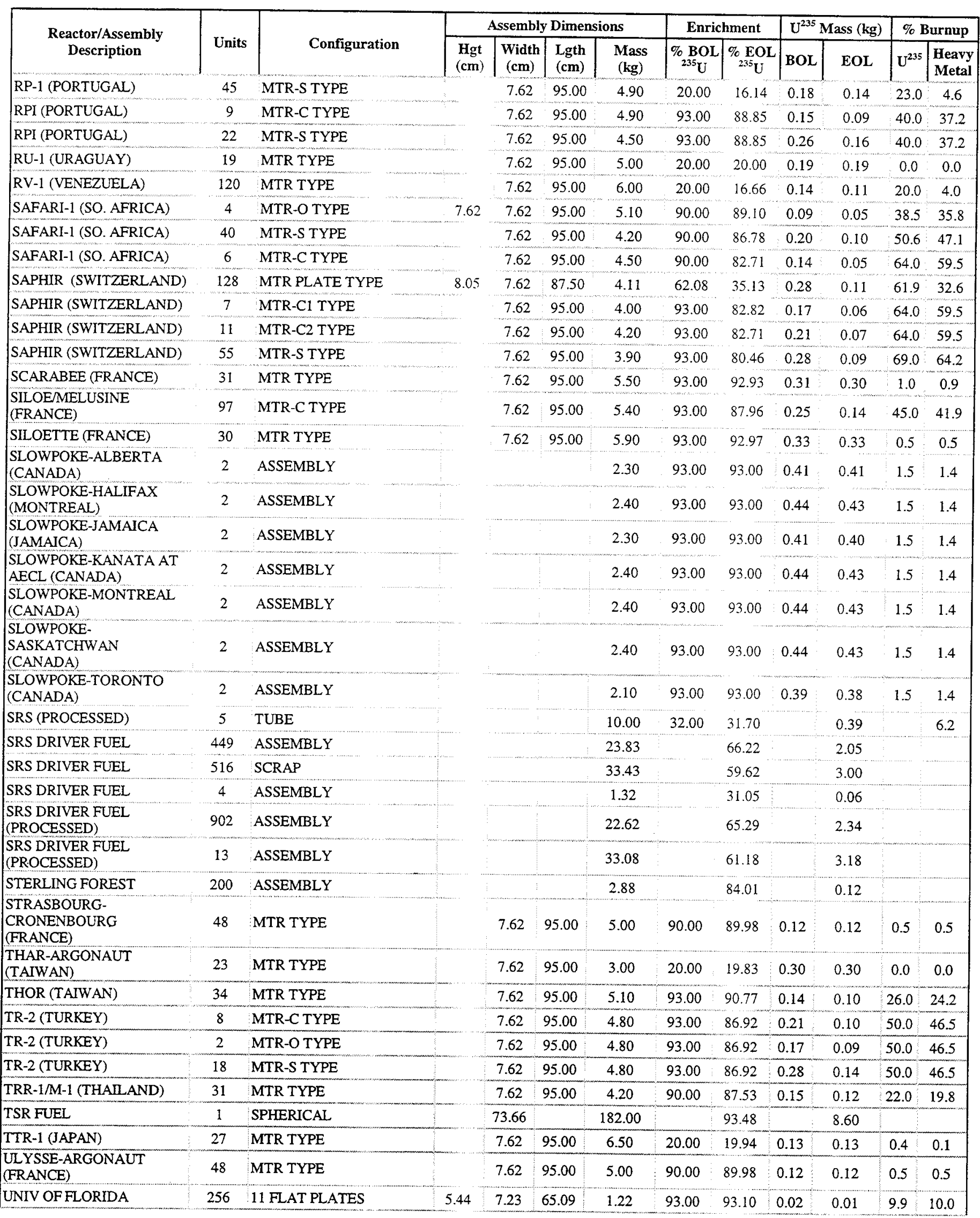




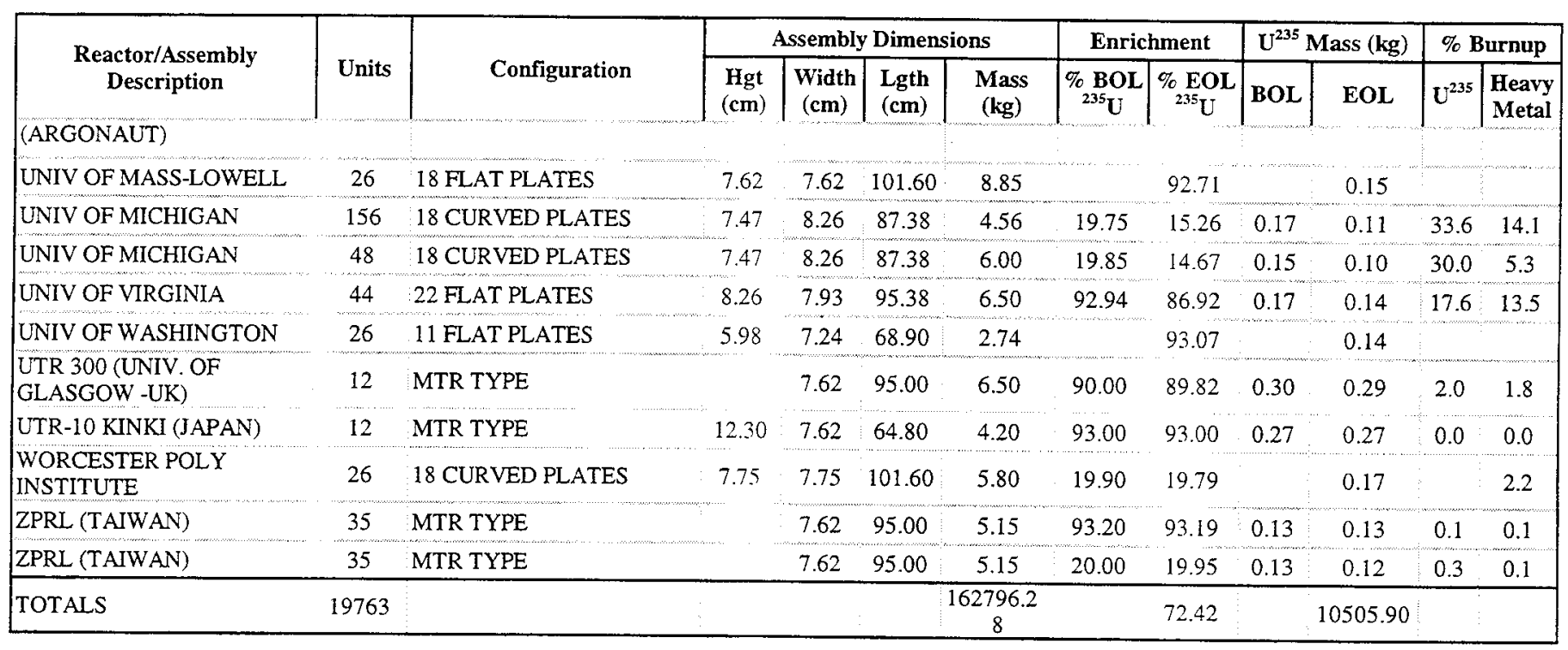

\section{A.3.4 U-Si}

Table A.5 provides a detailed listing of the current projection of types and quantities of uranium silicon fuel materials to be handled by TSF, respectively. The definition of the acronyms in the Reactor/Assembly Description column for this table may be found in the IAEA Directory of Nuclear Reactors and the IAEA Nuclear Research Reactors in the World. The table may include some assemblies that are scheduled for reprocessing. The contents of the table may change as processing is completed.

Table A.5 Uranium/Silicon Inventory

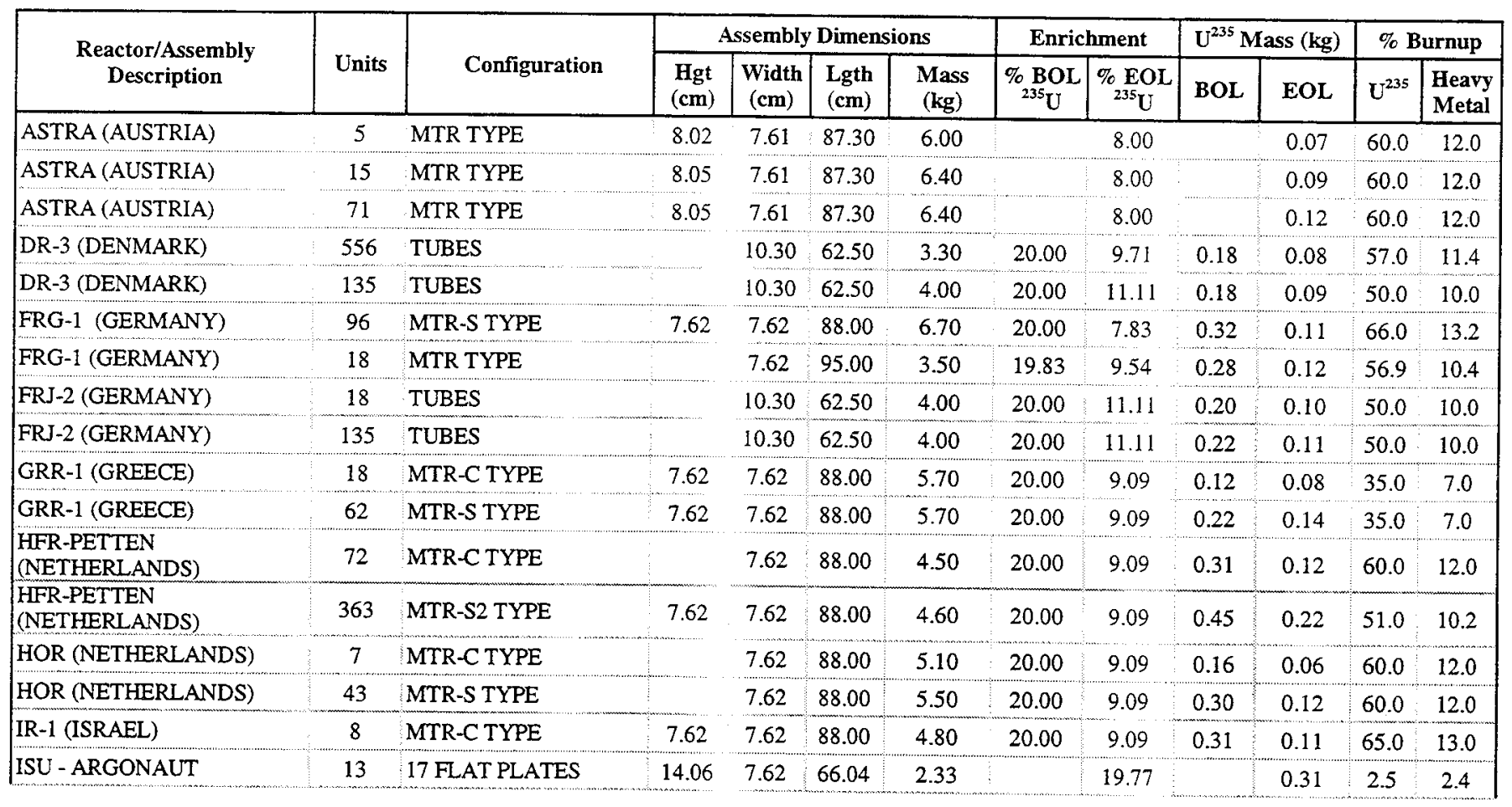




\begin{tabular}{|c|c|c|c|c|c|c|c|c|c|c|c|c|}
\hline \multirow{2}{*}{$\begin{array}{l}\text { Reactor/Assembly } \\
\text { Description }\end{array}$} & \multirow[b]{2}{*}{ Units } & \multirow[b]{2}{*}{ Configuration } & \multicolumn{4}{|c|}{ Assembly Dimensions } & \multicolumn{2}{|c|}{ Enrichment } & \multicolumn{2}{|c|}{$\mathrm{U}^{235}$ Mass (kg) } & \multicolumn{2}{|c|}{ \% Burnup } \\
\hline & & & $\begin{array}{l}\text { Hgt } \\
(\mathbf{c m})\end{array}$ & $\begin{array}{c}\text { Width } \\
(\mathrm{cm})\end{array}$ & $\begin{array}{l}\text { Lgth } \\
(\mathrm{cm})\end{array}$ & $\begin{array}{c}\text { Mass } \\
(\mathrm{kg})\end{array}$ & $\mid \begin{array}{c}\% \mathrm{BOL} \\
{ }_{235} \mathrm{U}\end{array}$ & ${ }_{235}^{\% \text { EOL }}$ & BOL & EOL & $\mathrm{U}^{235}$ & $\begin{array}{l}\text { Heavy } \\
\text { Metal }\end{array}$ \\
\hline JMTR (JAPAN) & 149 & 10 FLAT PLATES & & 7.62 & 88.00 & 5.40 & 20.00 & 14.89 & 0.28 & 0.19 & 30.0 & 6.0 \\
\hline JMTR (JAPAN) & 574 & ASSEMBLY & & 7.62 & 88.00 & 7.30 & 20.00 & 14.89 & 0.41 & 0.29 & 30.0 & 6.0 \\
\hline JRR-4 (JAPAN) & 47 & MTR TYPE & & 7.62 & 88.00 & 6.00 & 20.00 & 15.79 & 0.20 & 0.15 & 25.0 & 5.0 \\
\hline KUR (JAPAN) & 17 & MTR-C TYPE & 7.62 & 7.62 & 88.00 & 4.60 & 20.00 & 16.83 & 0.10 & 0.09 & 19.0 & 3.8 \\
\hline KUR (JAPAN) & 70 & MTR-S TYPE & & 7.62 & 88.00 & 5.40 & 20.00 & 16.49 & 0.21 & 0.17 & 21.0 & 4.2 \\
\hline MNR (CANADA) & 8 & MTR-C TYPE & & 7.62 & 88.00 & 4.90 & 20.00 & 9.09 & 0.16 & 0.08 & 50.0 & 10.0 \\
\hline MNR (CANADA) & 35 & MTR-S TYPE & & 7.62 & 88.00 & 5.40 & 20.00 & 9.09 & 0.29 & 0.14 & 50.0 & 10.0 \\
\hline NEREIDE (FRANCE) & 46 & 12 CURVED PLATES & 7.98 & 7.57 & 87.30 & 62.50 & 19.85 & 19.80 & 0.15 & 0.15 & 0.3 & 0.1 \\
\hline NRU (CANADA) & 1527 & MULTI-PIN CLUSTER & & & & 6.60 & 20.00 & 7.83 & 0.49 & 0.12 & 76.0 & 15.0 \\
\hline OHIO STATE & 414 & 18 FLAT PLATES & & 7.62 & 88.90 & 0.48 & 19.75 & 19.73 & 0.20 & 0.01 & 93.8 & 93.8 \\
\hline ORR & 32 & 19 CURVED PLATES & 8.03 & 7.60 & 65.09 & 5.00 & 19.85 & 19.82 & 0.32 & 0.32 & 0.0 & 0.0 \\
\hline ORR - MISC & 10 & SCRAP IN CANISTER & & & & 26.50 & & 6.74 & & 0.23 & & \\
\hline OSIRIS (FRANCE) & 177 & MTR-C TYPE & 7.62 & 7.62 & 88.00 & 7.00 & 20.00 & 9.09 & 0.39 & 0.17 & 55.0 & 11.0 \\
\hline OSIRIS (FRANCE) & 724 & MTR-S TYPE & 7.62 & 7.62 & 88.00 & 7.50 & 20.00 & 9.09 & 0.51 & 0.23 & 55.0 & 11.0 \\
\hline PURDUE UNIVERSITY & 22 & 10 FLAT PLATES & 0.15 & 7.01 & 68.80 & 1.70 & 19.00 & 19.00 & 0.22 & 0.22 & 0.0 & 0.0 \\
\hline R-2 (SWEDEN) & 580 & MTR-C TYPE & 7.62 & 7.62 & 88.00 & 6.20 & 20.00 & 9.09 & 0.40 & 0.16 & 60.0 & 12.0 \\
\hline R-2 (SWEDEN) & 82 & MTR-C TYPE & 7.62 & 7.62 & 88.00 & 6.20 & 20.00 & 9.09 & 0.25 & 0.06 & 76.0 & 15.2 \\
\hline RINSC & 122 & 18 FLAT PLATES & & 7.62 & 100.33 & 5.50 & 19.90 & 18.79 & 0.28 & 0.26 & 6.0 & 1.2 \\
\hline SAPHIR (SWITZERLAND) & 39 & MTR PLATE TYPE & 8.05 & 7.62 & 87.50 & 4.00 & 19.84 & 11.58 & 0.41 & 0.21 & 48.3 & 11.3 \\
\hline SEOUL $1 \& 2$ (SO. KOREA) & 48 & MULTI-PIN CLUSTER & & & & 4.30 & 20.00 & 8.68 & 0.25 & 0.09 & 62.0 & 12.4 \\
\hline SEOUL $1 \& 2$ (SO. KOREA) & 120 & MULTI-PIN CLUSTER & & & & 6.60 & 20.00 & 7.83 & 0.44 & 0.15 & 66.0 & 13.2 \\
\hline TR-2 (TURKEY) & 9 & MTR-C2 TYPE & 7.62 & 7.62 & 88.00 & 5.60 & 20.00 & 9.09 & 0.31 & 0.12 & 60.0 & 12.0 \\
\hline TR-2 (TURKEY) & 32 & MTR-S TYPE & 7.62 & 7.62 & 88.00 & 6.60 & 20.00 & 9.09 & 0.42 & 0.17 & 60.0 & 12.0 \\
\hline UMRR & 28 & 24 CUR VED PLATES & 7.57 & 8.74 & 87.00 & 6.20 & 19.75 & 19.83 & 0.22 & 0.19 & 16.7 & 17.0 \\
\hline UNIV OF FLORIDA & 25 & 11 FLAT PLATES & 5.44 & 7.23 & 65.09 & 5.50 & 19.72 & 19.72 & 0.22 & 0.22 & 0.0 & 0.0 \\
\hline UNIV OF MASS-LOWELL & 41 & 18 FLAT PLATES & 7.62 & 7.62 & 101.60 & 8.86 & & 19.73 & & 0.26 & 0.0 & 0.0 \\
\hline UNIV OF MICHIGAN & 330 & 18 CURVED PLATES & 7.47 & 8.26 & 87.38 & 5.49 & 19.81 & 19.81 & 0.21 & 0.21 & 0.0 & 0.0 \\
\hline UNIV OF VIRGINIA & 33 & 22 FLAT PLATES & 8.26 & 7.61 & 93.88 & 5.80 & 19.75 & 19.03 & 0.28 & 0.23 & 14.6 & 11.4 \\
\hline TOTALS & 6976 & & & & & 42149.33 & & & & 1098.40 & & \\
\hline
\end{tabular}

\section{A.4 Description of Al-SNF Materials}

There are three basic fuel types that have been fabricated for research and test reactors. Originally fuel was made from cast aluminum-uranium alloys; later it was made using powder metallurgy techniques. These fuels include $\mathrm{UAl}_{x}, \mathrm{U}_{3} \mathrm{O}_{8}$ and $\mathrm{U}_{3} \mathrm{Si}_{2}$ powders that are mixed with aluminum powder and hot/cold rolled to produce flat plates. Fuel elements are irradiated from 30 to $60 \%$ burnup.

\section{A.4.1 U. Oxide/Failed Clad \& Al}

A photomicrograph of the $\mathrm{U}_{3} \mathrm{O}_{8}$ fuel at high burnup is shown in Figure A.7. During irradiation, centerline temperatures up to about $200^{\circ} \mathrm{C}$ can occur which enhances diffusion of uranium and aluminum in the fuel meat. These effects produce chemical reactions between various fuel particles and matrix materials. For example, in $\mathrm{U}_{3} \mathrm{O}_{8}$ fuels a $\mathrm{UAl}_{x}$ type phase is formed. This phase can be seen in Figure A.7. 
The kinetics of oxide dissolution in molten aluminum are slow because of the stability of the oxide phase, but the diffusion reactions in oxide fuels during irradiation will enhance the solubility of the fuel phase. During the MD treatment, the $\mathrm{U}_{3} \mathrm{O}_{8}$ fuel is expected to dissolve adequately when melted. For irradiated oxide fuels, the melting behavior is expected to be governed by the uraniumaluminum phase diagram shown in Figure A. 8 of this report.

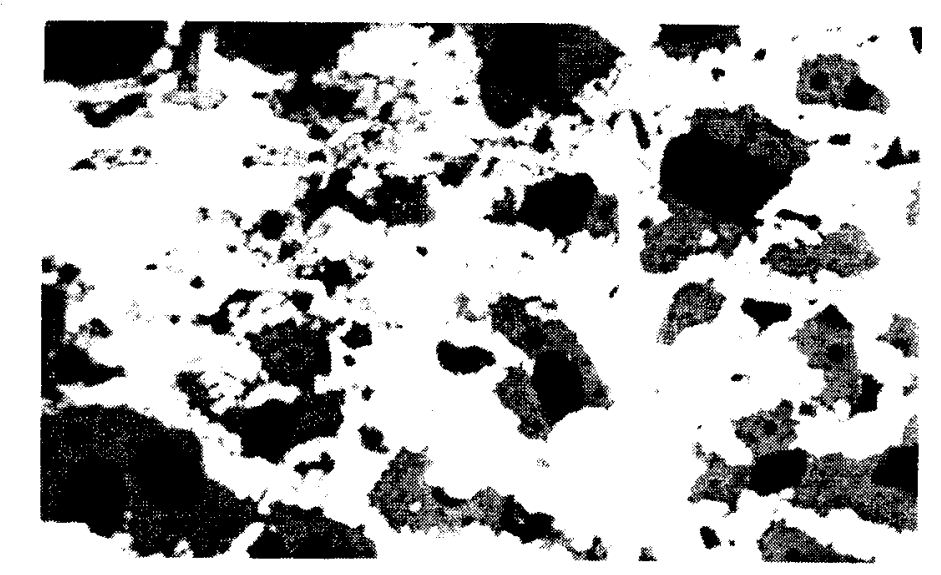

Figure A.7 High Burnup $\mathrm{U}_{3} \mathrm{O}_{8}$-AI Fuel Irradiated in Research and Test Reactors

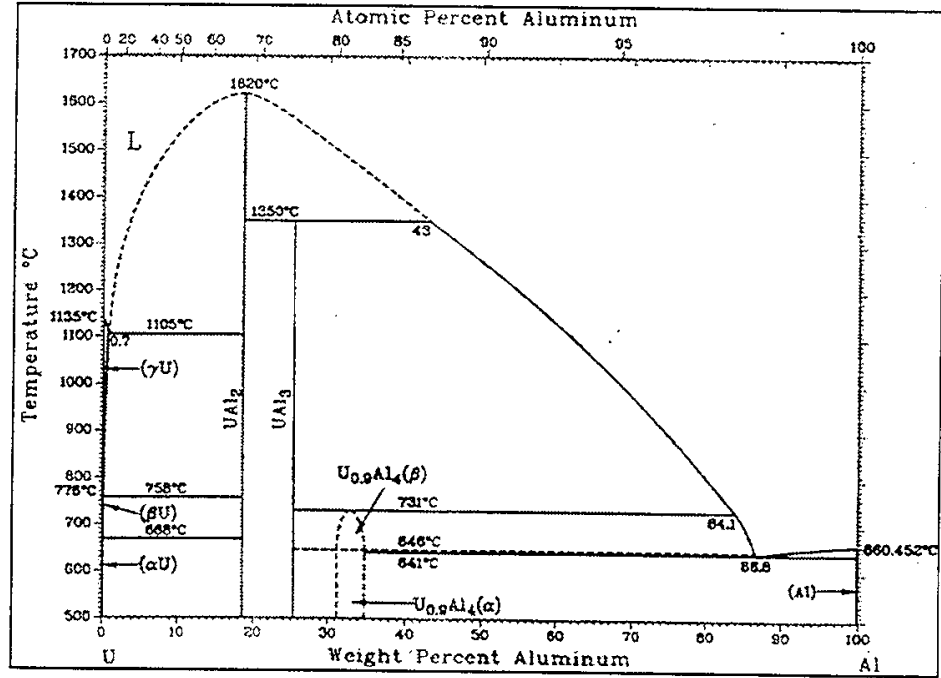

Figure A.8 Binary Phase Diagram of the Uranium-Aluminum System

\section{A.4.2 UAlx/Al}

A photomicrograph of the $\mathrm{UAl}_{\mathrm{x}}$ fuel at high burnup is shown in Figure A.9. During irradiation, centerline temperatures up to about $200^{\circ} \mathrm{C}$ can occur which enhances diffusion of uranium and aluminum in the fuel meat. For aluminide fuels, no reaction occurs at the particle-matrix boundary because of the thermodynamic stability of the aluminide phase present in the fuel as shown in Figure A.9. 
During the MD treatment, the $\mathrm{UAl}_{\mathrm{x}}$ fuel is expected to dissolve adequately when melted. For aluminide fuels, the melting behavior is expected to be governed by the uranium-aluminum phase diagram shown in Figure A.8 of this report.

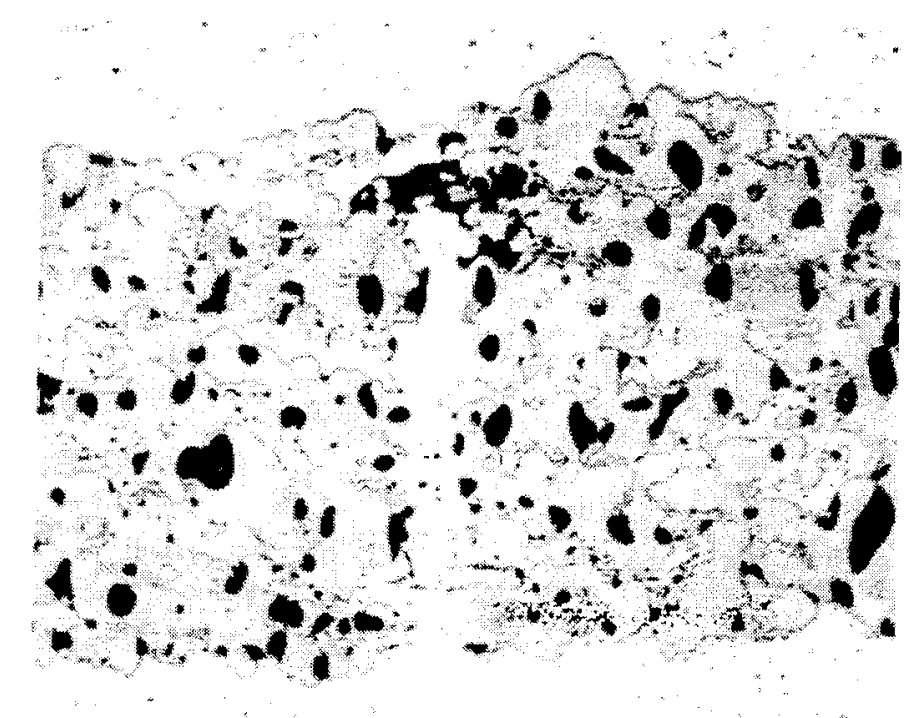

Figure A.9 High Burnup $\mathrm{UAl}_{\mathrm{x}}-\mathrm{Al}$ Fuel Irradiated in Research and Test Reactors

\section{A.4.3 U-Si}

A photomicrograph of the $\mathrm{U}_{3} \mathrm{Si}_{2}$ fuel at high burnup is shown in Figure A.10. During irradiation, centerline temperatures up to about $200^{\circ} \mathrm{C}$ can occur which enhances diffusion of uranium and aluminum in the fuel meat. These effects produce chemical reactions between various fuel particles and matrix materials. In silicide fuels aluminum-silicon phases form at the aluminum $\mathrm{U}_{3} \mathrm{Si}_{2}$ particle interface. These phases can be seen in Figure A.10.

During the MD treatment, the $\mathrm{U}_{3} \mathrm{Si}_{2}$ fuel is expected to dissolve adequately when melted. For silicide fuels, the uranium-aluminum-silicon ternary phase diagram is necessary to predict process conditions. The ternary diagram at $950^{\circ} \mathrm{C}$ was constructed from binary phase diagrams and is shown in Figure A. 11 


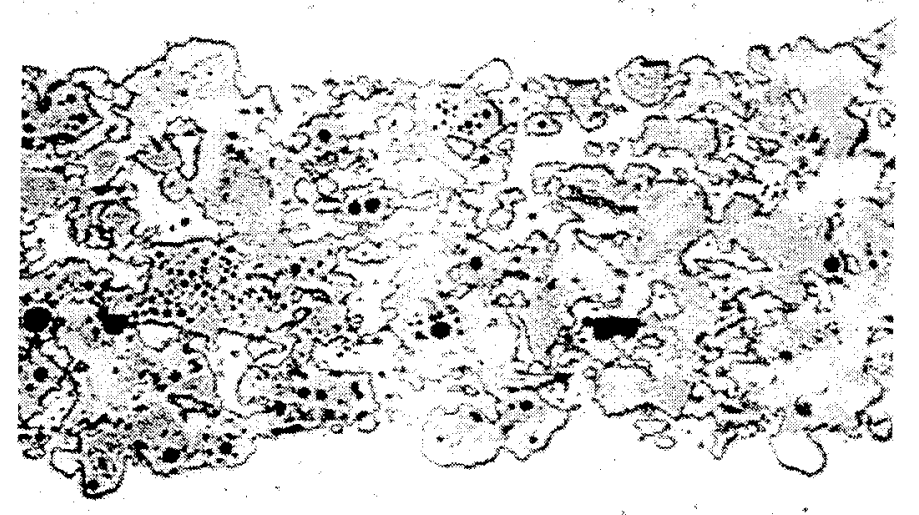

Figure A.10 High Burnup $\mathrm{U}_{3} \mathrm{Si}_{2}$-Al Fuel Irradiated in Research and Test Reactors

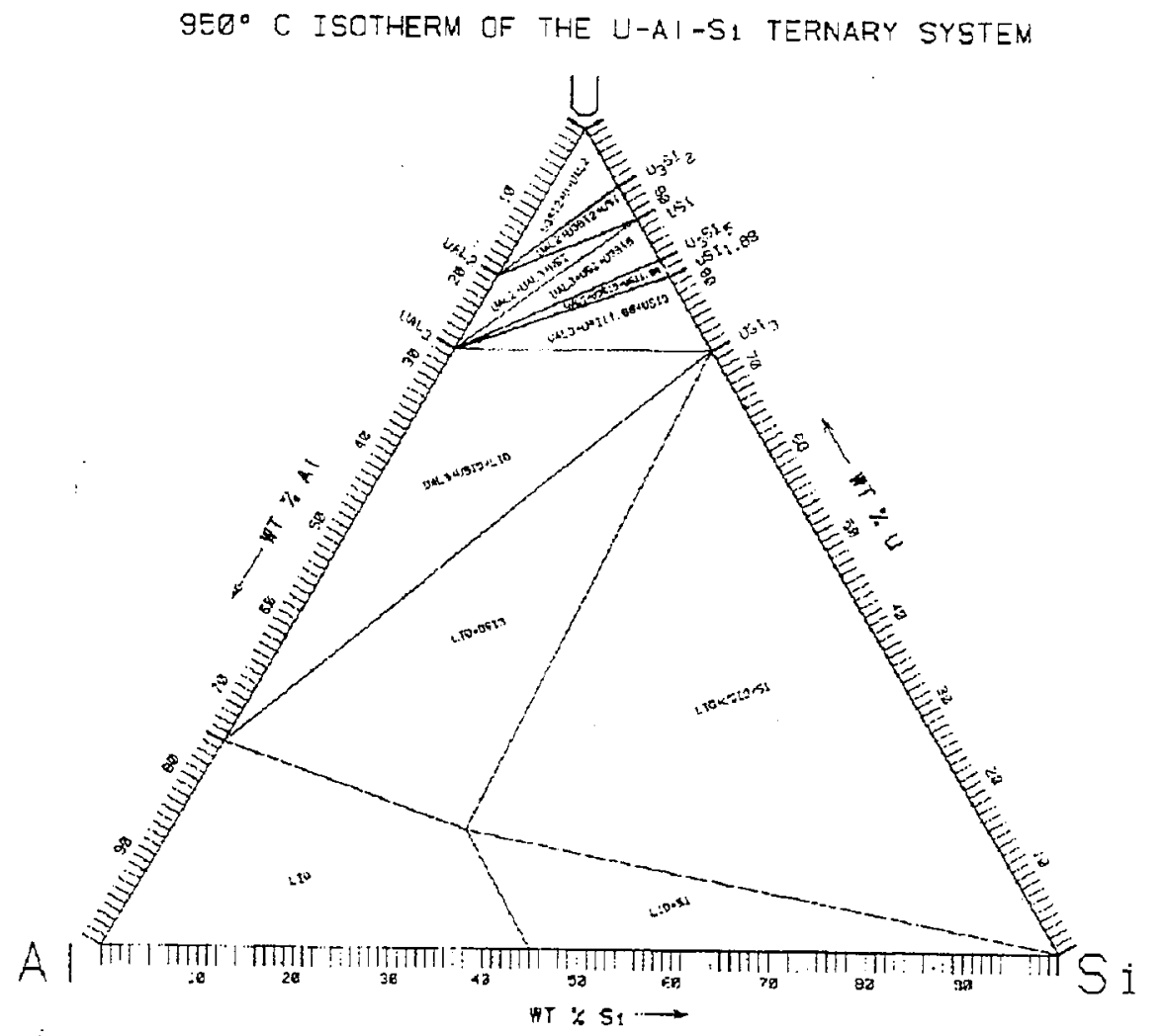

Figure A.11 Ternary Isothermal Section from the U-Al-Si System at $950^{\circ} \mathrm{C}$ 
At $950^{\circ} \mathrm{C}$ the aluminum-uranium-silicon system has a relatively large liquidus region near the aluminum-rich end of the phase diagram. Calculations, based on aluminide fuels, for the silicide loading indicate that the melt composition will be in the range of about 1 to $10 \mathrm{wt} \%$ uranium, 0.1-0.8 wt\% silicon, and 98.9-89.2 wt\% aluminum for various MTR assemblies. According to these calculations, the alloy is expected to melt between 660 and $960^{\circ} \mathrm{C}$. Melting of silicide fuels can be accomplished using the same melt-dilute process; however, dilution may not be a concern for these low enriched elements. Melting and casting would, however, consolidate the fuel and produce a SNF form consistent with other fuel types.

\section{A.4.4 Sterling Forest Oxide-Type Material}

This material consists of small particles of uranium-oxide fuel meat that has characteristics similar to that of Sterling Forest spent nuclear fuel.

\section{A.4.5 Physical Condition of Fuel Assemblies}

The SNF is typically stored under water where corrosion may be severe unless strict control of the water purity is maintained [2]. Several dry storage facilities are in use at foreign reactor sites. Prolonged underwater storage is not desirable because of the cost of operating and maintaining a properly controlled water system and the limited space and handling capabilities available at most reactor facilities.

An evaluation of the physical condition of a large portion of the fuel assemblies in wet and dry storage at foreign and domestic research reactor sites was recently performed [3]. Only minor corrosion and mechanical damage indicating cladding penetration was observed in approximately $7 \%$ of the 1700 fuel assemblies examined.

New criteria for acceptance of Al-SNF for SRS basin storage without special canning are provided in Reference 4. These criteria should be used for pre-treatment or pre-drying basin storage for the TSF if using the melt-dilute or direct disposal technologies, respectively.

\section{A.4.6 Constituents of DOE SNF}

In order to ensure the proper operation of the melt-dilute process and offgas system it is fundamentally necessary to compile a complete list of all the possible chemical species available for reaction. These various chemical species are present as radionuclides from the fission process, cladding alloy additions, fuel meat alloy additions/impurities, and also from any melt-dilute process additions such as the depleted uranium used for dilution of the ${ }^{235} U$ content. Table A. 6 contains a listing of the chemical species expected for the various cladding materials that will be processed in the melt-dilute process. Table A.7 lists the composition of aluminum powder used in $\mathrm{UAl}_{\mathrm{x}}$-fuel manufacturing. A chemical analysis of the depleted uranium used for dilution is provided in Table A.8. 
Table A.6 Compositions of Typical MTR Cladding Alloys Manufactured by CERCA, NUKEM, and B\&W

\begin{tabular}{|c|c|c|c|c|c|c|c|}
\hline Elements & AG1 & AG2 & AG3 & AlFeNi & AlMg1 & AlMg2 & 6061 \\
\hline $\mathrm{Mg}$ & $1.1-1.4$ & $1.8-2.3$ & $2.5-3.0$ & $0.8-1.2$ & $0.7-1.1$ & $1.7-2.4$ & $0.8-1.2$ \\
\hline $\mathrm{B}$ & - & 0.001 & - & 0.001 & 0.001 & 0.001 & 0.001 \\
\hline $\mathrm{Cd}$ & - & 0.001 & - & 0.001 & 0.001 & 0.001 & 0.001 \\
\hline $\mathrm{Cu}$ & - & 0.008 & - & 0.008 & 0.008 & 0.008 & $0.2-0.40$ \\
\hline $\mathrm{Fe}$ & - & $0.2-0.4$ & - & $0.8-1.2$ & 0.45 & 0.40 & 0.70 \\
\hline $\mathrm{Si}$ & - & 0.3 & - & 0.30 & 0.30 & 0.30 & $0.40-0.80$ \\
\hline $\mathrm{Cr}$ & - & 0.3 & - & $0.2-0.5$ & 0.10 & 0.30 & $0.04-0.35$ \\
\hline $\mathrm{Mn}$ & - & 0.7 & - & $0.2-0.6$ & 0.15 & 0.30 & 0.15 \\
\hline $\mathrm{Li}$ & - & 0.001 & - & 0.001 & 0.001 & 0.001 & 0.008 \\
\hline $\mathrm{Zn}$ & - & - & - & $0.06-0.14$ & 0.05 & 0.03 & 0.25 \\
\hline $\mathrm{Ti}$ & - & - & - & $0.02-0.08$ & - & 0.10 & 0.25 \\
\hline $\mathrm{Al}$ & - & Bal. & - & Bal. & Bal. & Bal. & Bal. \\
\hline Others & - & 0.03 & - & 0.03. & 0.15 & 0.15 & 0.15 \\
\hline
\end{tabular}

Table A.7 Composition of Al Powder Used for $\mathrm{UAl}_{\mathrm{x}}$ Fuel Manufacturing

\begin{tabular}{|c|c|}
\hline Element & Wt $\%$ \\
\hline $\mathrm{Al}$ & $99.00 \mathrm{~min}$ \\
\hline $\mathrm{Si}+\mathrm{Fe}$ & $1.0 \mathrm{max}$ \\
\hline $\mathrm{Cu}$ & $0.05-0.20$ \\
\hline $\mathrm{Mn}$ & $0.05 \mathrm{max}$ \\
\hline $\mathrm{Zn}$ & $0.05 \max$ \\
\hline Other (each) & $0.05 \max$ \\
\hline Others (total) & $0.15 \max$ \\
\hline
\end{tabular}

Table A.8 Chemical Analysis of the Depleted Uranium for Dilution

\begin{tabular}{|c|c|}
\hline Element & Concentration, ppm \\
\hline $\mathrm{C}$ & 400 \\
\hline $\mathrm{N}_{2}$ & 50 \\
\hline $\mathrm{H}_{2}$ & 1 \\
\hline $\mathrm{O}_{2}$ & 10 \\
\hline $\mathrm{Al}$ & $<6$ \\
\hline $\mathrm{B}$ & $<0.15$ \\
\hline $\mathrm{Cd}$ & $<20$ \\
\hline $\mathrm{Cr}$ & 10 \\
\hline $\mathrm{Cu}$ & 3 \\
\hline $\mathrm{Fe}$ & $125-225$ \\
\hline $\mathrm{Mg}$ & $<4$ \\
\hline $\mathrm{Mn}$ & 5 \\
\hline $\mathrm{Mo}$ & $<6$ \\
\hline $\mathrm{Si}$ & $125-225$ \\
\hline $\mathrm{Sn}$ & 5 \\
\hline $\mathrm{Zr}$ & $<5$ \\
\hline
\end{tabular}


Table A.9 provides a bounding assessment of the fission product, actinide, and light element inventories expected in a single DOE SNF assembly. The table provides data for a low enriched (20\%) and a highly enriched (93\%) MTR assembly. The burnup was conservatively assumed to be $250 \mathrm{MWd}$ /assembly. The final column of data (MAX) provides the maximum value of the other six columns. It is expected that the fission product inventory of any individual assembly processed by the MD technology option would be bounded by the high enrichment data provided in Table A.9, while the actinide inventory will be significantly bound by the low enrichment data. Actinide inventory data may be excessively conservative due to the assumed burnup, and consideration is ongoing.

Table A.9 Bounding Estimates of Mass of Fission Products, Actinides, and Light Elements (grams)

\begin{tabular}{|c|c|c|c|c|c|c|c|}
\hline \multirow{2}{*}{$\begin{array}{l}\text { Radionuclide/ } \\
\text { Element } \\
\end{array}$} & \multicolumn{3}{|c|}{ Low Enrichment } & \multicolumn{3}{|c|}{ High Enrichment } & \multirow{2}{*}{ MAX } \\
\hline & initial & $5.0 \mathrm{yr}$ & $10.0 \mathrm{yr}$ & initial & $5.0 \mathrm{yr}$ & $10.0 \mathrm{yr}$ & \\
\hline Ac225 & $1.28 \mathrm{E}-16$ & $3.13 \mathrm{E}-16$ & $1.21 \mathrm{E}-15$ & $9.00 \mathrm{E}-18$ & $5.99 \mathrm{E}-16$ & $1.34 \mathrm{E}-15$ & $1.34 \mathrm{E}-15$ \\
\hline Ac227 & $1.13 \mathrm{E}-14$ & $1.15 \mathrm{E}-13$ & $2.96 \mathrm{E}-13$ & $1.48 \mathrm{E}-13$ & $1.71 \mathrm{E}-10$ & $6.33 \mathrm{E}-10$ & $6.33 \mathrm{E}-10$ \\
\hline Actinium & $1.14 \mathrm{E}-14$ & 1.15E-13 & 2.97E-13 & 1.48E-13 & $1.71 \mathrm{E}-10$ & $6.33 E-10$ & 6.33E-10 \\
\hline Al27 & $1.03 \mathrm{E}+03$ & $1.03 E+03$ & $1.03 \mathrm{E}+03$ & $1.03 E+03$ & $1.03 \mathrm{E}+03$ & $1.03 E+03$ & $1.03 \mathrm{E}+03$ \\
\hline Aluminum & $1.03 \mathrm{E}+03$ & $1.03 \mathrm{E}+03$ & $1.03 E+03$ & $1.03 E+03$ & $1.03 E+03$ & $1.03 E+03$ & $1.03 \mathrm{E}+03$ \\
\hline Am241 & $6.84 \mathrm{E}-04$ & 4.79E-01 & $8.51 \mathrm{E}-01$ & $9.99 \mathrm{E}-05$ & $1.48 \mathrm{E}-02$ & $2.61 \mathrm{E}-02$ & $8.51 \mathrm{E}-01$ \\
\hline Am242 & $1.03 \mathrm{E}-04$ & $1.18 \mathrm{E}-10$ & $1.15 \mathrm{E}-10$ & $1.18 \mathrm{E}-06$ & $1.44 \mathrm{E}-11$ & $1.40 \mathrm{E}-11$ & $1.03 E-04$ \\
\hline $\operatorname{Am} 242 m$ & $9.34 \mathrm{E}-06$ & $9.11 \mathrm{E}-06$ & $8.89 \mathrm{E}-06$ & $1.14 \mathrm{E}-06$ & $1.12 \mathrm{E}-06$ & $1.09 \mathrm{E}-06$ & 9.34E-06 \\
\hline Am243 & $1.61 E+00$ & $1.70 \mathrm{E}+00$ & $1.70 \mathrm{E}+00$ & $1.83 \mathrm{E}-04$ & $1.89 \mathrm{E}-04$ & $1.88 \mathrm{E}-04$ & $1.70 \mathrm{E}+00$ \\
\hline $\operatorname{Am} 245$ & $1.41 \mathrm{E}-16$ & $2.71 \mathrm{E}-18$ & $5.20 \mathrm{E}-20$ & $0.00 \mathrm{E}+00$ & $0.00 \mathrm{E}+00$ & $0.00 \mathrm{E}+00$ & $1.41 \mathrm{E}-16$ \\
\hline Americium & $1.61 \mathrm{E}+00$ & $2.18 \mathrm{E}+00$ & $2.55 \mathrm{E}+00$ & 2.85E-04 & $1.49 \mathrm{E}-02$ & 2.63E-02 & $2.55 \mathrm{E}+00$ \\
\hline Sb121 & $2.40 \mathrm{E}-02$ & $2.53 \mathrm{E}-02$ & $2.53 \mathrm{E}-02$ & $1.71 \mathrm{E}-02$ & $1.78 \mathrm{E}-02$ & $1.78 \mathrm{E}-02$ & $2.53 \mathrm{E}-02$ \\
\hline Sb123 & $2.71 \mathrm{E}-02$ & 2.95E-02 & $2.95 \mathrm{E}-02$ & $2.00 \mathrm{E}-02$ & $2.23 \mathrm{E}-02$ & $2.23 \mathrm{E}-02$ & 2.95E-02 \\
\hline $\mathrm{Sb} 124$ & $1.06 \mathrm{E}-03$ & 7.79E-13 & $5.73 \mathrm{E}-22$ & $7.18 \mathrm{E}-05$ & $5.28 \mathrm{E}-14$ & $3.89 \mathrm{E}-23$ & $1.06 \mathrm{E}-03$ \\
\hline Sb125 & $5.79 \mathrm{E}-02$ & $1.80 \mathrm{E}-02$ & $5.08 \mathrm{E}-03$ & $3.78 \mathrm{E}-02$ & $1.16 \mathrm{E}-02$ & $3.26 \mathrm{E}-03$ & $5.79 \mathrm{E}-02$ \\
\hline Sb126 & $5.20 \mathrm{E}-04$ & $5.64 \mathrm{E}-09$ & $5.64 \mathrm{E}-09$ & $6.54 \mathrm{E}-05$ & $3.00 \mathrm{E}-09$ & 3.00E-09 & $5.20 \mathrm{E}-04$ \\
\hline $\mathrm{Sb} 126 \mathrm{~m}$ & $1.19 \mathrm{E}-06$ & $4.29 \mathrm{E}-11$ & $4.29 \mathrm{E}-11$ & $9.89 \mathrm{E}-08$ & $2.28 \mathrm{E}-11$ & $2.28 \mathrm{E}-11$ & $1.19 \mathrm{E}-06$ \\
\hline Antimony & $1.11 \mathrm{E}-01$ & $7.28 \mathrm{E}-02$ & $5.98 \mathrm{E}-02$ & $7.50 \mathrm{E}-02$ & $5.16 \mathrm{E}-02$ & 4.33E-02 & $1.11 \mathrm{E}-01$ \\
\hline As75 & $8.49 \mathrm{E}-04$ & $8.50 \mathrm{E}-04$ & $8.50 \mathrm{E}-04$ & $1.00 \mathrm{E}-03$ & $1.00 \mathrm{E}-03$ & $1.00 \mathrm{E}-03$ & $1.00 \mathrm{E}-03$ \\
\hline Arsenic & $8.49 \mathrm{E}-04$ & 8.50E-04 & 8.50E-04 & $1.00 \mathrm{E}-03$ & $1.00 \mathrm{E}-03$ & $1.00 \mathrm{E}-03$ & $1.00 \mathrm{E}-03$ \\
\hline Ba132 & $8.66 \mathrm{E}-07$ & $1.58 \mathrm{E}-06$ & $1.58 \mathrm{E}-06$ & $1.76 \mathrm{E}-07$ & $2.73 \mathrm{E}-07$ & $2.73 \mathrm{E}-07$ & $1.58 \mathrm{E}-06$ \\
\hline Ba133 & $6.00 \mathrm{E}-10$ & $4.31 \mathrm{E}-10$ & $3.10 \mathrm{E}-10$ & $8.06 \mathrm{E}-11$ & $5.80 \mathrm{E}-11$ & $4.18 \mathrm{E}-11$ & $6.00 \mathrm{E}-10$ \\
\hline Ba134 & $1.50 \mathrm{E}-02$ & $1.08 \mathrm{E}+00$ & $1.28 \mathrm{E}+00$ & $3.16 \mathrm{E}-03$ & $2.01 E-01$ & $2.38 \mathrm{E}-01$ & $1.28 \mathrm{E}+00$ \\
\hline $\mathrm{Ba} 135$ & $1.63 \mathrm{E}-04$ & 1.70E-04 & $1.73 \mathrm{E}-04$ & $3.20 \mathrm{E}-06$ & $4.19 \mathrm{E}-06$ & $5.14 \mathrm{E}-06$ & $1.73 \mathrm{E}-04$ \\
\hline $\mathrm{Ba} 136$ & $2.70 \mathrm{E}-02$ & $8.53 \mathrm{E}-02$ & $8.53 \mathrm{E}-02$ & $7.65 \mathrm{E}-03$ & $1.28 \mathrm{E}-02$ & $1.28 \mathrm{E}-02$ & $8.53 \mathrm{E}-02$ \\
\hline Bal36m & $1.80 \mathrm{E}-09$ & $0.00 E+00$ & $0.00 \mathrm{E}+00$ & $1.56 \mathrm{E}-10$ & $0.00 \mathrm{E}+00$ & $0.00 \mathrm{E}+00$ & $1.80 \mathrm{E}-09$ \\
\hline Ba137 & $1.80 \mathrm{E}-02$ & $1.08 \mathrm{E}+00$ & $2.01 E+00$ & $1.70 \mathrm{E}-02$ & $1.08 \mathrm{E}+00$ & $2.04 E+00$ & $2.04 \mathrm{E}+00$ \\
\hline Ba137m & $1.70 \mathrm{E}-06$ & $1.31 \mathrm{E}-06$ & 1.17E-06 & $1.55 \mathrm{E}-06$ & $1.33 \mathrm{E}-06$ & $1.19 \mathrm{E}-06$ & $1.70 \mathrm{E}-06$ \\
\hline $\mathrm{Ba} 138$ & $9.91 \mathrm{E}+00$ & $9.93 \mathrm{E}+00$ & $9.93 \mathrm{E}+00$ & $1.05 \mathrm{E}+01$ & $1.05 \mathrm{E}+01$ & $1.05 \mathrm{E}+01$ & $1.05 \mathrm{E}+01$ \\
\hline $\mathrm{Ba} 140$ & $3.11 \mathrm{E}+00$ & $0.00 \mathrm{E}+00$ & $0.00 \mathrm{E}+00$ & $3.43 \mathrm{E}+00$ & $0.00 \mathrm{E}+00$ & $0.00 \mathrm{E}+00$ & $3.43 \mathrm{E}+00$ \\
\hline Barium & $1.31 \mathrm{E}+01$ & $1.22 \mathrm{E}+01$ & $1.33 E+01$ & $1.40 \mathrm{E}+01$ & $1.18 \mathrm{E}+01$ & $1.28 \mathrm{E}+01$ & $1.40 \mathrm{E}+01$ \\
\hline Bk249 & $3.51 \mathrm{E}-08$ & $7.14 \mathrm{E}-10$ & $1.36 \mathrm{E}-11$ & $9.15 \mathrm{E}-18$ & $1.79 \mathrm{E}-19$ & $3.41 \mathrm{E}-21$ & $3.51 \mathrm{E}-08$ \\
\hline Bk250 & $3.96 \mathrm{E}-09$ & $2.71 \mathrm{E}-17$ & $2.94 \mathrm{E}-19$ & $0.00 \mathrm{E}+00$ & $0.00 \mathrm{E}+00$ & $0.00 \mathrm{E}+00$ & $3.96 \mathrm{E}-09$ \\
\hline
\end{tabular}




\begin{tabular}{|c|c|c|c|c|c|c|c|}
\hline \multirow{2}{*}{$\begin{array}{l}\text { Radionuclide/ } \\
\text { Element }\end{array}$} & \multicolumn{3}{|c|}{ Low Enrichment } & \multicolumn{3}{|c|}{ High Enrichment } & \multirow{2}{*}{ MAX } \\
\hline & initial & $5.0 \mathrm{yr}$ & $10.0 \mathrm{yr}$ & initial & $5.0 \mathrm{yr}$ & $10.0 \mathrm{yr}$ & \\
\hline $\mathrm{Bk} 251$ & $4.16 \mathrm{E}-11$ & $2.69 \mathrm{E}-30$ & $0.00 \mathrm{E}+00$ & $0.00 \mathrm{E}+00$ & $0.00 E+00$ & $0.00 \mathrm{E}+00$ & $4.16 \mathrm{E}-11$ \\
\hline Berkelium & $3.91 \mathrm{E}-08$ & $7.14 \mathrm{E}-10$ & $1.36 \mathrm{E}-11$ & 9.15E-18 & $1.79 \mathrm{E}-19$ & $3.41 \mathrm{E}-21$ & $3.91 \mathrm{E}-08$ \\
\hline $\operatorname{Be} 9$ & $1.49 \mathrm{E}-07$ & $1.49 \mathrm{E}-07$ & $1.49 \mathrm{E}-07$ & $1.54 \mathrm{E}-07$ & $1.54 \mathrm{E}-07$ & $1.54 \mathrm{E}-07$ & $1.54 \mathrm{E}-07$ \\
\hline $\operatorname{Be} 10$ & $9.90 \mathrm{E}-07$ & $9.90 \mathrm{E}-07$ & $9.90 \mathrm{E}-07$ & $1.02 \mathrm{E}-06$ & $1.02 \mathrm{E}-06$ & $1.02 \mathrm{E}-06$ & 1.02E-06 \\
\hline Beryllium & $1.14 \mathrm{E}-06$ & $1.14 \mathrm{E}-06$ & $1.14 \mathrm{E}-06$ & $1.18 \mathrm{E}-06$ & 1.18E-06 & $1.18 \mathrm{E}-06$ & 1.18E-06 \\
\hline $\mathrm{Bi} 209$ & $4.80 \mathrm{E}-17$ & $1.31 \mathrm{E}-14$ & $9.64 \mathrm{E}-14$ & $5.06 \mathrm{E}-18$ & $3.35 \mathrm{E}-14$ & $1.45 \mathrm{E}-13$ & $1.45 \mathrm{E}-13$ \\
\hline $\mathrm{Bi} 210$ & $2.94 \mathrm{E}-20$ & $8.23 \mathrm{E}-19$ & $8.18 \mathrm{E}-18$ & $0.00 \mathrm{E}+00$ & $0.00 \mathrm{E}+00$ & $0.00 E+00$ & $8.18 \mathrm{E}-18$ \\
\hline $\mathrm{Bi} 211$ & $0.00 \mathrm{E}+00$ & $0.00 \mathrm{E}+00$ & $0.00 \mathrm{E}+00$ & $5.55 \mathrm{E}-21$ & $2.98 \mathrm{E}-17$ & $1.10 \mathrm{E}-16$ & $1.10 \mathrm{E}-16$ \\
\hline $\mathrm{Bi} 212$ & $1.21 \mathrm{E}-16$ & $2.05 \mathrm{E}-12$ & $3.63 \mathrm{E}-12$ & $2.68 \mathrm{E}-16$ & $1.74 \mathrm{E}-13$ & $2.94 \mathrm{E}-13$ & $3.63 \mathrm{E}-12$ \\
\hline $\mathrm{Bi} 213$ & $0.00 \mathrm{E}+00$ & $0.00 \mathrm{E}+00$ & $0.00 \mathrm{E}+00$ & $2.70 \mathrm{E}-20$ & $1.80 \mathrm{E}-18$ & $4.03 \mathrm{E}-18$ & $4.03 \mathrm{E}-18$ \\
\hline Bismuth & $1.69 \mathrm{E}-16$ & $2.06 \mathrm{E}-12$ & 3.72E-12 & $2.73 \mathrm{E}-16$ & $2.07 \mathrm{E}-13$ & 4.39E-13 & 3.72E-12 \\
\hline $\mathrm{Br} 79$ & $1.06 \mathrm{E}-08$ & $3.85 \mathrm{E}-07$ & $7.59 \mathrm{E}-07$ & $9.64 \mathrm{E}-09$ & $4.28 \mathrm{E}-07$ & $8.46 \mathrm{E}-07$ & $8.46 \mathrm{E}-07$ \\
\hline $\mathrm{Br} 81$ & $1.53 \mathrm{E}-01$ & $1.53 \mathrm{E}-01$ & $1.53 \mathrm{E}-01$ & $1.76 \mathrm{E}-01$ & $1.76 \mathrm{E}-01$ & $1.76 \mathrm{E}-01$ & $1.76 \mathrm{E}-01$ \\
\hline Bromine & $1.53 \mathrm{E}-01$ & $1.53 \mathrm{E}-01$ & $1.53 \mathrm{E}-01$ & $1.76 \mathrm{E}-01$ & $1.76 \mathrm{E}-01$ & $1.76 \mathrm{E}-01$ & $1.76 \mathrm{E}-01$ \\
\hline $\mathrm{Cd} 108$ & $1.24 \mathrm{E}-06$ & $1.24 \mathrm{E}-06$ & $1.24 \mathrm{E}-06$ & $2.29 \mathrm{E}-08$ & $2.29 \mathrm{E}-08$ & $2.29 \mathrm{E}-08$ & $1.24 \mathrm{E}-06$ \\
\hline $\mathrm{Cd} 109$ & $1.07 \mathrm{E}-09$ & $6.95 \mathrm{E}-11$ & $4.50 \mathrm{E}-12$ & $7.20 \mathrm{E}-12$ & $4.68 \mathrm{E}-13$ & $3.03 \mathrm{E}-14$ & $1.07 \mathrm{E}-09$ \\
\hline Cd110 & $4.31 \mathrm{E}-01$ & $4.49 \mathrm{E}-01$ & $4.49 \mathrm{E}-01$ & $5.11 \mathrm{E}-03$ & $5.30 \mathrm{E}-03$ & $5.31 \mathrm{E}-03$ & $4.49 \mathrm{E}-01$ \\
\hline $\mathrm{Cd} 111$ & $9.55 \mathrm{E}-02$ & $1.61 \mathrm{E}-01$ & $1.61 E-01$ & $2.04 \mathrm{E}-02$ & $2.59 \mathrm{E}-02$ & $2.59 \mathrm{E}-02$ & $1.61 \mathrm{E}-01$ \\
\hline $\mathrm{Cd} 112$ & $8.44 \mathrm{E}-02$ & $8.94 \mathrm{E}-02$ & $8.94 \mathrm{E}-02$ & $2.03 \mathrm{E}-02$ & $2.09 \mathrm{E}-02$ & $2.09 \mathrm{E}-02$ & $8.94 \mathrm{E}-02$ \\
\hline $\mathrm{Cd} 113$ & 7.49E-05 & $6.74 \mathrm{E}-04$ & $6.74 \mathrm{E}-04$ & $6.71 \mathrm{E}-04$ & $7.95 \mathrm{E}-04$ & $7.95 \mathrm{E}-04$ & $7.95 \mathrm{E}-04$ \\
\hline $\mathrm{Cd} 113 \mathrm{~m}$ & $1.05 \mathrm{E}-03$ & $8.29 \mathrm{E}-04$ & $6.48 \mathrm{E}-04$ & $3.49 E-04$ & $2.74 \mathrm{E}-04$ & $2.15 \mathrm{E}-04$ & $1.05 \mathrm{E}-03$ \\
\hline $\mathrm{Cd} 114$ & 8.33E-02 & $8.33 \mathrm{E}-02$ & 8.33E-02 & $3.85 \mathrm{E}-02$ & $3.85 \mathrm{E}-02$ & $3.85 \mathrm{E}-02$ & $8.33 \mathrm{E}-02$ \\
\hline $\mathrm{Cd} 115 \mathrm{~m}$ & $6.75 \mathrm{E}-04$ & $3.18 \mathrm{E}-16$ & $1.49 \mathrm{E}-28$ & $4.16 \mathrm{E}-04$ & $1.95 \mathrm{E}-16$ & $9.15 \mathrm{E}-29$ & $6.75 \mathrm{E}-04$ \\
\hline Cd116 & $3.19 \mathrm{E}-02$ & $3.19 \mathrm{E}-02$ & $3.19 \mathrm{E}-02$ & $2.24 \mathrm{E}-02$ & $2.24 \mathrm{E}-02$ & $2.24 \mathrm{E}-02$ & $3.19 \mathrm{E}-02$ \\
\hline Cadmium & $7.28 \mathrm{E}-01$ & $8.16 \mathrm{E}-01$ & 8.16E-01 & 1.08E-01 & 1.14E-01 & $1.14 \mathrm{E}-01$ & $8.16 \mathrm{E}-01$ \\
\hline Cf249 & $6.55 \mathrm{E}-11$ & $3.64 \mathrm{E}-08$ & $3.68 \mathrm{E}-08$ & $6.64 \mathrm{E}-20$ & $9.13 \mathrm{E}-18$ & $9.21 \mathrm{E}-18$ & $3.68 \mathrm{E}-08$ \\
\hline Cf250 & $1.76 \mathrm{E}-08$ & $1.66 \mathrm{E}-08$ & $1.28 \mathrm{E}-08$ & $5.41 \mathrm{E}-19$ & $4.40 \mathrm{E}-19$ & $3.38 \mathrm{E}-19$ & $1.76 \mathrm{E}-08$ \\
\hline $\mathrm{Cf} 251$ & $6.00 \mathrm{E}-09$ & $6.01 E-09$ & $5.99 \mathrm{E}-09$ & $0.00 \mathrm{E}+00$ & $0.00 \mathrm{E}+00$ & $0.00 \mathrm{E}+00$ & $6.01 \mathrm{E}-09$ \\
\hline Cf252 & $1.68 \mathrm{E}-08$ & $4.53 \mathrm{E}-09$ & $1.22 \mathrm{E}-09$ & $0.00 \mathrm{E}+00$ & $0.00 \mathrm{E}+00$ & $0.00 \mathrm{E}+00$ & $1.68 \mathrm{E}-08$ \\
\hline $\mathrm{Cf} 253$ & $2.91 \mathrm{E}-10$ & $0.00 \mathrm{E}+00$ & $0.00 \mathrm{E}+00$ & $0.00 \mathrm{E}+00$ & $0.00 \mathrm{E}+00$ & $0.00 \mathrm{E}+00$ & $2.91 \mathrm{E}-10$ \\
\hline $\mathrm{Cf} 254$ & $3.40 \mathrm{E}-12$ & $2.78 \mathrm{E}-21$ & $2.28 \mathrm{E}-30$ & $0.00 \mathrm{E}+00$ & $0.00 \mathrm{E}+00$ & $0.00 \mathrm{E}+00$ & $3.40 \mathrm{E}-12$ \\
\hline Californium & 4.07E-08 & $6.35 \mathrm{E}-08$ & $5.67 \mathrm{E}-08$ & $6.08 \mathrm{E}-19$ & $9.57 \mathrm{E}-18$ & $9.55 \mathrm{E}-18$ & $6.35 E-08$ \\
\hline $\mathrm{Ca} 46$ & $4.08 \mathrm{E}-19$ & $4.08 \mathrm{E}-19$ & $4.08 \mathrm{E}-19$ & $0.00 \mathrm{E}+00$ & $0.00 \mathrm{E}+00$ & $0.00 \mathrm{E}+00$ & $4.08 \mathrm{E}-19$ \\
\hline Calcium & 4.08E-19 & $4.08 \mathrm{E}-19$ & 4.08E-19 & $0.00 \mathrm{E}+00$ & $0.00 \mathrm{E}+00$ & $0.00 \mathrm{E}+00$ & $4.08 \mathrm{E}-19$ \\
\hline $\mathrm{Cl4}$ & $2.00 \mathrm{E}-07$ & $2.00 \mathrm{E}-07$ & $2.00 \mathrm{E}-07$ & $2.08 \mathrm{E}-07$ & $2.08 \mathrm{E}-07$ & $2.06 \mathrm{E}-07$ & $2.08 \mathrm{E}-07$ \\
\hline Carbon & $2.00 \mathrm{E}-07$ & 2.00E-07 & 2.00E-07 & 2.08E-07 & 2.08E-07 & $2.06 \mathrm{E}-07$ & 2.08E-07 \\
\hline Cel139 & $3.38 \mathrm{E}-07$ & $3.41 \mathrm{E}-11$ & $3.45 \mathrm{E}-15$ & $9.19 \mathrm{E}-08$ & $9.30 \mathrm{E}-12$ & $9.40 \mathrm{E}-16$ & $3.38 \mathrm{E}-07$ \\
\hline $\mathrm{Ce} 140$ & $6.44 \mathrm{E}+00$ & $1.01 E+01$ & $1.01 \mathrm{E}+01$ & $6.20 \mathrm{E}+00$ & $1.01 \mathrm{E}+01$ & $1.01 \mathrm{E}+01$ & $1.01 \mathrm{E}+01$ \\
\hline $\mathrm{Cel} 41$ & $4.43 E+00$ & $5.40 E-17$ & $6.54 \mathrm{E}-34$ & $5.64 \mathrm{E}+00$ & $6.88 \mathrm{E}-17$ & 8.33E-34 & $5.64 \mathrm{E}+00$ \\
\hline $\mathrm{Cel} 42$ & $9.86 \mathrm{E}+00$ & $9.88 \mathrm{E}+00$ & $9.88 \mathrm{E}+00$ & $9.53 \mathrm{E}+00$ & $9.55 \mathrm{E}+00$ & $9.55 \mathrm{E}+00$ & $9.88 \mathrm{E}+00$ \\
\hline $\mathrm{Ce} 144$ & $7.40 \mathrm{E}+00$ & $8.70 \mathrm{E}-02$ & $1.02 \mathrm{E}-03$ & $8.44 E+00$ & $9.93 \mathrm{E}-02$ & $1.17 \mathrm{E}-03$ & $8.44 \mathrm{E}+00$ \\
\hline Cerium & $2.81 \mathrm{E}+01$ & $2.00 E+01$ & $1.99 \mathrm{E}+01$ & $2.98 \mathrm{E}+01$ & $1.97 \mathrm{E}+01$ & $1.96 \mathrm{E}+01$ & $2.98 \mathrm{E}+01$ \\
\hline $\mathrm{Cs} 133$ & $4.83 \mathrm{E}+00$ & $5.91 E+00$ & $5.91 E+00$ & $8.24 E+00$ & $9.90 \mathrm{E}+00$ & $9.90 \mathrm{E}+00$ & $9.90 \mathrm{E}+00$ \\
\hline Cs134 & $1.30 \mathrm{E}+00$ & $2.43 \mathrm{E}-01$ & $4.51 \mathrm{E}-02$ & $2.43 \mathrm{E}-01$ & $4.53 \mathrm{E}-02$ & $8.43 \mathrm{E}-03$ & $1.30 \mathrm{E}+00$ \\
\hline Cs 135 & $1.10 \mathrm{E}+00$ & $1.17 \mathrm{E}+00$ & $1.17 \mathrm{E}+00$ & $5.50 \mathrm{E}-01$ & $6.28 \mathrm{E}-01$ & $6.28 \mathrm{E}-01$ & $1.17 \mathrm{E}+00$ \\
\hline Cs 136 & $5.83 \mathrm{E}-02$ & $0.00 \mathrm{E}+00$ & $0.00 \mathrm{E}+00$ & $5.13 \mathrm{E}-03$ & $0.00 \mathrm{E}+00$ & $0.00 \mathrm{E}+00$ & $5.83 \mathrm{E}-02$ \\
\hline Cs 137 & $9.69 E+00$ & $8.63 E+00$ & $7.69 \mathrm{E}+00$ & $9.78 \mathrm{E}+00$ & $8.71 E+00$ & $7.76 \mathrm{E}+00$ & $9.78 \mathrm{E}+00$ \\
\hline Cesium & $1.70 \mathrm{E}+01$ & $1.60 \mathrm{E}+01$ & $1.48 \mathrm{E}+01$ & $1.88 \mathrm{E}+01$ & $1.93 \mathrm{E}+01$ & $1.83 E+01$ & $1.93 \mathrm{E}+01$ \\
\hline $\mathrm{Cr} 52$ & $6.19 \mathrm{E}-06$ & $6.20 \mathrm{E}-06$ & $6.20 \mathrm{E}-06$ & $1.25 \mathrm{E}-06$ & $1.25 \mathrm{E}-06$ & $1.25 \mathrm{E}-06$ & $6.20 \mathrm{E}-06$ \\
\hline
\end{tabular}




\begin{tabular}{|c|c|c|c|c|c|c|c|}
\hline \multirow{2}{*}{$\begin{array}{l}\text { Radionuclide/ } \\
\text { Element }\end{array}$} & \multicolumn{3}{|c|}{ Low Enrichment } & \multicolumn{3}{|c|}{ High Enrichment } & \multirow{2}{*}{ MAX } \\
\hline & initial & $5.0 \mathrm{yr}$ & $10.0 \mathrm{yr}$ & initial & $5.0 \mathrm{yr}$ & $10.0 \mathrm{yr}$ & \\
\hline $\mathrm{Cr} 53$ & $3.30 \mathrm{E}-07$ & $3.30 \mathrm{E}-07$ & $3.30 \mathrm{E}-07$ & $4.90 \mathrm{E}-09$ & $4.90 \mathrm{E}-09$ & $4.90 \mathrm{E}-09$ & $3.30 \mathrm{E}-07$ \\
\hline $\mathrm{Cr} 54$ & $8.14 \mathrm{E}-07$ & $1.35 \mathrm{E}-05$ & $1.38 \mathrm{E}-05$ & $2.11 \mathrm{E}-07$ & $2.81 \mathrm{E}-06$ & $2.86 \mathrm{E}-06$ & $1.38 \mathrm{E}-05$ \\
\hline Chromium & $7.33 E-06$ & 2.00E-05 & 2.03E-05 & $1.46 \mathrm{E}-06$ & $4.06 \mathrm{E}-06$ & 4.11E-06 & 2.03E-05 \\
\hline $\operatorname{Co58}$ & $9.29 \mathrm{E}-16$ & $1.66 \mathrm{E}-23$ & $2.94 \mathrm{E}-31$ & $0.00 \mathrm{E}+00$ & $0.00 \mathrm{E}+00$ & $0.00 \mathrm{E}+00$ & $9.29 \mathrm{E}-16$ \\
\hline $\operatorname{Co59}$ & $1.44 \mathrm{E}-08$ & $2.65 \mathrm{E}-07$ & $2.65 \mathrm{E}-07$ & $3.05 \mathrm{E}-13$ & $2.48 \mathrm{E}-12$ & $2.48 \mathrm{E}-12$ & 2.65E-07 \\
\hline Co60 & 1.13E-09 & $5.88 \mathrm{E}-10$ & $3.04 \mathrm{E}-10$ & $1.64 \mathrm{E}-15$ & $8.50 \mathrm{E}-16$ & $4.40 \mathrm{E}-16$ & $1.13 \mathrm{E}-09$ \\
\hline Cobalt & $1.55 \mathrm{E}-08$ & $2.66 \mathrm{E}-07$ & 2.65E-07 & $3.07 E-13$ & $2.48 \mathrm{E}-12$ & $2.48 \mathrm{E}-12$ & $2.66 \mathrm{E}-07$ \\
\hline Cu63 & $1.13 \mathrm{E}-20$ & $9.16 \mathrm{E}-18$ & $1.80 \mathrm{E}-17$ & $0.00 \mathrm{E}+00$ & $0.00 \mathrm{E}+00$ & $0.00 \mathrm{E}+00$ & $1.80 \mathrm{E}-17$ \\
\hline Copper & $1.13 \mathrm{E}-20$ & $9.16 \mathrm{E}-18$ & $1.80 \mathrm{E}-17$ & $0.00 \mathrm{E}+00$ & $0.00 \mathrm{E}+00$ & $0.00 \mathrm{E}+00$ & $1.80 \mathrm{E}-17$ \\
\hline $\mathrm{Cm} 241$ & $1.30 \mathrm{E}-09$ & $2.25 \mathrm{E}-26$ & $0.00 \mathrm{E}+00$ & $4.90 \mathrm{E}-13$ & $8.48 \mathrm{E}-30$ & $0.00 E+00$ & $1.30 \mathrm{E}-09$ \\
\hline $\mathrm{Cm} 242$ & $1.65 \mathrm{E}-03$ & $7.59 \mathrm{E}-07$ & $2.35 \mathrm{E}-08$ & $9.25 \mathrm{E}-06$ & $7.24 \mathrm{E}-09$ & $2.84 \mathrm{E}-09$ & $1.65 \mathrm{E}-03$ \\
\hline $\mathrm{Cm} 243$ & $4.98 \mathrm{E}-05$ & $4.41 \mathrm{E}-05$ & $3.90 \mathrm{E}-05$ & $4.88 \mathrm{E}-08$ & $4.31 \mathrm{E}-08$ & $3.83 E-08$ & $4.98 \mathrm{E}-05$ \\
\hline $\mathrm{Cm} 244$ & $5.83 \mathrm{E}-01$ & $5.33 \mathrm{E}-01$ & $4.40 \mathrm{E}-01$ & $8.66 \mathrm{E}-06$ & $7.75 \mathrm{E}-06$ & $6.40 \mathrm{E}-06$ & $5.83 \mathrm{E}-01$ \\
\hline $\mathrm{Cm} 245$ & $1.24 \mathrm{E}-02$ & $1.24 \mathrm{E}-02$ & $1.24 \mathrm{E}-02$ & $9.44 \mathrm{E}-08$ & $9.43 \mathrm{E}-08$ & $9.43 \mathrm{E}-08$ & $1.24 \mathrm{E}-02$ \\
\hline $\mathrm{Cm} 246$ & $8.80 \mathrm{E}-03$ & $8.79 \mathrm{E}-03$ & $8.79 \mathrm{E}-03$ & $1.98 \mathrm{E}-09$ & $1.98 \mathrm{E}-09$ & $1.98 \mathrm{E}-09$ & $8.80 \mathrm{E}-03$ \\
\hline $\mathrm{Cm} 247$ & $5.53 \mathrm{E}-05$ & $5.53 \mathrm{E}-05$ & $5.53 \mathrm{E}-05$ & $1.63 \mathrm{E}-12$ & $1.63 \mathrm{E}-12$ & $1.63 \mathrm{E}-12$ & $5.53 \mathrm{E}-05$ \\
\hline $\mathrm{Cm} 248$ & $6.30 \mathrm{E}-06$ & $6.31 \mathrm{E}-06$ & $6.33 \mathrm{E}-06$ & $9.60 \mathrm{E}-15$ & $9.60 \mathrm{E}-15$ & $9.60 \mathrm{E}-15$ & $6.33 \mathrm{E}-06$ \\
\hline $\mathrm{Cm} 250$ & $6.43 \mathrm{E}-12$ & $6.44 \mathrm{E}-12$ & $6.43 \mathrm{E}-12$ & $0.00 \mathrm{E}+00$ & $0.00 \mathrm{E}+00$ & $0.00 \mathrm{E}+00$ & $6.44 \mathrm{E}-12$ \\
\hline Curium & $6.05 \mathrm{E}-01$ & $5.54 \mathrm{E}-01$ & 4.61E-01 & $1.81 \mathrm{E}-05$ & $7.90 \mathrm{E}-06$ & $6.54 \mathrm{E}-06$ & $6.05 \mathrm{E}-01$ \\
\hline Dy160 & $6.75 \mathrm{E}-05$ & $1.31 \mathrm{E}-03$ & $1.31 \mathrm{E}-03$ & $3.44 \mathrm{E}-06$ & $2.59 \mathrm{E}-05$ & $2.59 \mathrm{E}-05$ & $1.31 \mathrm{E}-03$ \\
\hline Dy161 & 7.63E-04 & $3.68 \mathrm{E}-03$ & $3.68 \mathrm{E}-03$ & $1.21 \mathrm{E}-04$ & $1.59 \mathrm{E}-04$ & $1.59 \mathrm{E}-04$ & $3.68 \mathrm{E}-03$ \\
\hline Dy162 & $1.49 \mathrm{E}-03$ & $1.49 \mathrm{E}-03$ & $1.49 \mathrm{E}-03$ & $5.73 \mathrm{E}-05$ & $5.73 \mathrm{E}-05$ & $5.73 \mathrm{E}-05$ & $1.49 \mathrm{E}-03$ \\
\hline Dyl 63 & $1.31 \mathrm{E}-03$ & $1.31 \mathrm{E}-03$ & $1.31 \mathrm{E}-03$ & $2.13 \mathrm{E}-05$ & $2.13 \mathrm{E}-05$ & $2.13 \mathrm{E}-05$ & $1.31 \mathrm{E}-03$ \\
\hline Dy164 & $9.88 \mathrm{E}-05$ & $9.89 \mathrm{E}-05$ & $9.89 \mathrm{E}-05$ & $4.25 \mathrm{E}-06$ & $4.25 \mathrm{E}-06$ & $4.25 \mathrm{E}-06$ & $9.89 E-05$ \\
\hline Dysprosium & $3.73 \mathrm{E}-03$ & $7.89 \mathrm{E}-03$ & $7.89 \mathrm{E}-03$ & 2.07E-04 & 2.67E-04 & $2.67 \mathrm{E}-04$ & $7.89 \mathrm{E}-03$ \\
\hline Es253 & $1.56 \mathrm{E}-11$ & $3.14 \mathrm{E}-36$ & $0.00 \mathrm{E}+00$ & $0.00 \mathrm{E}+00$ & $0.00 \mathrm{E}+00$ & $0.00 \mathrm{E}+00$ & $1.56 \mathrm{E}-11$ \\
\hline Es254 & $5.60 \mathrm{E}-12$ & $5.68 \mathrm{E}-14$ & $5.75 \mathrm{E}-16$ & $0.00 \mathrm{E}+00$ & $0.00 \mathrm{E}+00$ & $0.00 \mathrm{E}+00$ & $5.60 \mathrm{E}-12$ \\
\hline Es255 & $3.21 \mathrm{E}-13$ & $2.69 \mathrm{E}-27$ & $0.00 \mathrm{E}+00$ & $0.00 \mathrm{E}+00$ & $0.00 \mathrm{E}+00$ & $0.00 \mathrm{E}+00$ & $3.21 \mathrm{E}-13$ \\
\hline Einsteinium & $2.15 \mathrm{E}-11$ & $5.68 \mathrm{E}-14$ & $5.75 \mathrm{E}-16$ & $0.00 \mathrm{E}+00$ & $0.00 \mathrm{E}+00$ & $0.00 \mathrm{E}+00$ & $2.15 \mathrm{E}-11$ \\
\hline Er166 & $2.34 \mathrm{E}-04$ & $3.94 \mathrm{E}-04$ & 3.94E-04 & $3.98 \mathrm{E}-07$ & $4.61 \mathrm{E}-07$ & $4.61 \mathrm{E}-07$ & $3.94 \mathrm{E}-04$ \\
\hline Er167 & $6.89 \mathrm{E}-06$ & $6.89 \mathrm{E}-06$ & $6.89 \mathrm{E}-06$ & $2.95 \mathrm{E}-09$ & $2.95 \mathrm{E}-09$ & $2.95 \mathrm{E}-09$ & $6.89 \mathrm{E}-06$ \\
\hline Er168 & $2.14 \mathrm{E}-05$ & $2.14 \mathrm{E}-05$ & $2.14 \mathrm{E}-05$ & $8.06 \mathrm{E}-10$ & $8.06 \mathrm{E}-10$ & $8.06 \mathrm{E}-10$ & $2.14 \mathrm{E}-05$ \\
\hline Er170 & $1.96 \mathrm{E}-08$ & $1.96 \mathrm{E}-08$ & $1.96 \mathrm{E}-08$ & $5.49 \mathrm{E}-10$ & $5.49 \mathrm{E}-10$ & $5.49 \mathrm{E}-10$ & $1.96 \mathrm{E}-08$ \\
\hline Erbium & 2.62E-04 & 4.22E-04 & 4.22E-04 & 4.02E-07 & $4.66 \mathrm{E}-07$ & $4.66 \mathrm{E}-07$ & $4.22 \mathrm{E}-04$ \\
\hline Eul49 & $1.08 \mathrm{E}-12$ & $1.33 \mathrm{E}-18$ & $1.64 \mathrm{E}-24$ & $4.26 \mathrm{E}-14$ & $5.26 \mathrm{E}-20$ & $6.50 \mathrm{E}-26$ & $1.08 \mathrm{E}-12$ \\
\hline Eu150 & $8.54 \mathrm{E}-13$ & $7.75 \mathrm{E}-13$ & $7.04 \mathrm{E}-13$ & $4.56 \mathrm{E}-11$ & $4.14 \mathrm{E}-11$ & $3.76 \mathrm{E}-11$ & $4.56 \mathrm{E}-11$ \\
\hline Eu151 & $1.22 \mathrm{E}-07$ & $1.81 \mathrm{E}-03$ & $3.56 \mathrm{E}-03$ & $3.33 \mathrm{E}-05$ & $5.85 \mathrm{E}-03$ & $1.14 \mathrm{E}-02$ & $1.14 \mathrm{E}-02$ \\
\hline Eu152 & $1.30 \mathrm{E}-06$ & $1.00 \mathrm{E}-06$ & 7.71E-07 & $4.41 \mathrm{E}-05$ & $3.41 \mathrm{E}-05$ & $2.63 \mathrm{E}-05$ & $4.41 \mathrm{E}-05$ \\
\hline Eu153 & $5.61 \mathrm{E}-01$ & $8.91 \mathrm{E}-01$ & $8.91 \mathrm{E}-01$ & $4.03 \mathrm{E}-01$ & $4.44 \mathrm{E}-01$ & $4.44 \mathrm{E}-01$ & $8.91 \mathrm{E}-01$ \\
\hline Eu 154 & $1.04 \mathrm{E}-01$ & $6.91 E-02$ & $4.63 \mathrm{E}-02$ & $4.04 \mathrm{E}-02$ & $2.70 \mathrm{E}-02$ & $1.80 \mathrm{E}-02$ & $1.04 \mathrm{E}-01$ \\
\hline Eu 155 & $3.61 \mathrm{E}-02$ & $1.74 E-02$ & $8.26 \mathrm{E}-03$ & $1.48 \mathrm{E}-02$ & $7.05 \mathrm{E}-03$ & $3.36 \mathrm{E}-03$ & 3.61E-02 \\
\hline Eu156 & $3.85 \mathrm{E}-01$ & $2.41 \mathrm{E}-37$ & $0.00 \mathrm{E}+00$ & $3.64 \mathrm{E}-02$ & $0.00 \mathrm{E}+00$ & $0.00 \mathrm{E}+00$ & $3.85 \mathrm{E}-01$ \\
\hline Europium & $1.09 \mathrm{E}+00$ & $9.80 \mathrm{E}-01$ & $9.49 \mathrm{E}-01$ & $4.94 \mathrm{E}-01$ & $4.84 \mathrm{E}-01$ & 4.77E-01 & $1.09 E+00$ \\
\hline F19 & $2.33 \mathrm{E}-17$ & $2.33 \mathrm{E}-17$ & $2.33 \mathrm{E}-17$ & $0.00 \mathrm{E}+00$ & $0.00 \mathrm{E}+00$ & $0.00 \mathrm{E}+00$ & $2.33 \mathrm{E}-17$ \\
\hline Fluorine & $2.33 \mathrm{E}-17$ & 2.33E-17 & 2.33E-17 & $0.00 \mathrm{E}+00$ & $0.00 \mathrm{E}+00$ & $0.00 \mathrm{E}+00$ & 2.33E-17 \\
\hline Fr223 & $0.00 \mathrm{E}+00$ & $0.00 \mathrm{E}+00$ & $0.00 \mathrm{E}+00$ & $3.81 E-21$ & $4.41 \mathrm{E}-18$ & $1.64 \mathrm{E}-17$ & $1.64 \mathrm{E}-17$ \\
\hline Francium & $0.00 \mathrm{E}+00$ & $0.00 \mathrm{E}+00$ & $0.00 \mathrm{E}+00$ & $3.81 \mathrm{E}-21$ & $4.41 \mathrm{E}-18$ & $1.64 \mathrm{E}-17$ & $1.64 \mathrm{E}-17$ \\
\hline Gd152 & $4.05 \mathrm{E}-06$ & $4.45 \mathrm{E}-06$ & $4.51 \mathrm{E}-06$ & $2.23 \mathrm{E}-05$ & $2.55 \mathrm{E}-05$ & $2.78 \mathrm{E}-05$ & $2.78 \mathrm{E}-05$ \\
\hline Gd153 & $5.83 \mathrm{E}-06$ & $3.09 \mathrm{E}-08$ & $1.64 \mathrm{E}-10$ & $7.28 \mathrm{E}-07$ & $3.85 \mathrm{E}-09$ & $2.04 \mathrm{E}-11$ & $5.83 \mathrm{E}-06$ \\
\hline
\end{tabular}




\begin{tabular}{|c|c|c|c|c|c|c|c|}
\hline \multirow{2}{*}{$\begin{array}{l}\text { Radionuclide/ } \\
\text { Element }\end{array}$} & \multicolumn{3}{|c|}{ Low Enrichment } & \multicolumn{3}{|c|}{ High Enrichment } & \multirow{2}{*}{ MAX } \\
\hline & initial & $5.0 \mathrm{yr}$ & $10.0 \mathrm{yr}$ & initial & $5.0 \mathrm{yr}$ & $10.0 \mathrm{yr}$ & \\
\hline Gd154 & $2.78 \mathrm{E}-04$ & $3.46 \mathrm{E}-02$ & $5.76 \mathrm{E}-02$ & $1.34 \mathrm{E}-04$ & $1.35 \mathrm{E}-02$ & $2.25 \mathrm{E}-02$ & $5.76 \mathrm{E}-02$ \\
\hline Gd155 & $1.15 \mathrm{E}-06$ & $1.90 \mathrm{E}-02$ & $2.81 \mathrm{E}-02$ & $1.24 \mathrm{E}-05$ & $7.75 \mathrm{E}-03$ & $1.14 \mathrm{E}-02$ & $2.81 \mathrm{E}-02$ \\
\hline Gd156 & $2.54 \mathrm{E}-01$ & $6.41 \mathrm{E}-01$ & $6.41 \mathrm{E}-01$ & 4.30E-02 & $7.96 \mathrm{E}-02$ & $7.96 \mathrm{E}-02$ & $6.41 \mathrm{E}-01$ \\
\hline Gd157 & $1.28 \mathrm{E}-03$ & $8.76 \mathrm{E}-02$ & $8.76 \mathrm{E}-02$ & $2.83 E-04$ & $7.06 \mathrm{E}-04$ & $7.06 \mathrm{E}-04$ & $8.76 \mathrm{E}-02$ \\
\hline Gd158 & $1.26 \mathrm{E}+00$ & $1.26 \mathrm{E}+00$ & $1.26 \mathrm{E}+00$ & $2.21 \mathrm{E}-02$ & $2.21 \mathrm{E}-02$ & $2.21 \mathrm{E}-02$ & $1.26 \mathrm{E}+00$ \\
\hline $\mathrm{Gd} 160$ & $6.78 \mathrm{E}-03$ & $6.78 \mathrm{E}-03$ & $6.78 \mathrm{E}-03$ & $6.10 \mathrm{E}-04$ & $6.10 \mathrm{E}-04$ & $6.10 \mathrm{E}-04$ & $6.78 \mathrm{E}-03$ \\
\hline Gadolinium & $1.52 \mathrm{E}+00$ & $2.05 E+00$ & $2.08 E+00$ & $6.62 \mathrm{E}-02$ & $1.24 \mathrm{E}-01$ & $1.37 \mathrm{E}-01$ & $2.08 \mathrm{E}+00$ \\
\hline Ga69 & $8.26 \mathrm{E}-10$ & $8.83 \mathrm{E}-10$ & $8.83 \mathrm{E}-10$ & $5.79 \mathrm{E}-10$ & $5.86 \mathrm{E}-10$ & $5.86 \mathrm{E}-10$ & $8.83 \mathrm{E}-10$ \\
\hline $\mathrm{Ga} 71$ & $2.36 \mathrm{E}-07$ & $2.40 \mathrm{E}-07$ & $2.40 \mathrm{E}-07$ & $1.96 \mathrm{E}-07$ & $1.96 \mathrm{E}-07$ & $1.96 \mathrm{E}-07$ & $2.40 \mathrm{E}-07$ \\
\hline Gallium & 2.37E-07 & 2.41E-07 & $2.41 \mathrm{E}-07$ & $1.97 \mathrm{E}-07$ & 1.97E-07 & 1.97E-07 & 2.41E-07 \\
\hline $\mathrm{Ge} 70$ & $2.31 \mathrm{E}-11$ & $2.33 \mathrm{E}-11$ & $2.33 \mathrm{E}-11$ & $9.46 \mathrm{E}-12$ & $9.46 \mathrm{E}-12$ & $9.46 \mathrm{E}-12$ & $2.33 \mathrm{E}-11$ \\
\hline $\mathrm{Ge} 72$ & $2.35 \mathrm{E}-05$ & $2.45 \mathrm{E}-05$ & $2.45 \mathrm{E}-05$ & $2.23 \mathrm{E}-05$ & $2.38 \mathrm{E}-05$ & $2.38 \mathrm{E}-05$ & $2.45 \mathrm{E}-05$ \\
\hline Ge73 & $6.90 \mathrm{E}-05$ & $6.98 \mathrm{E}-05$ & $6.98 \mathrm{E}-05$ & $9.69 \mathrm{E}-05$ & $9.75 \mathrm{E}-05$ & $9.75 \mathrm{E}-05$ & $9.75 \mathrm{E}-05$ \\
\hline Ge74 & $7.74 \mathrm{E}-05$ & $7.74 \mathrm{E}-05$ & $7.74 \mathrm{E}-05$ & $8.65 \mathrm{E}-05$ & $8.66 \mathrm{E}-05$ & $8.66 \mathrm{E}-05$ & $8.66 \mathrm{E}-05$ \\
\hline $\mathrm{Ge} 76$ & $2.79 \mathrm{E}-03$ & $2.79 \mathrm{E}-03$ & $2.79 \mathrm{E}-03$ & $3.34 \mathrm{E}-03$ & $3.34 \mathrm{E}-03$ & $3.34 \mathrm{E}-03$ & $3.34 \mathrm{E}-03$ \\
\hline Germanium & $2.96 \mathrm{E}-03$ & $2.96 \mathrm{E}-03$ & $2.96 \mathrm{E}-03$ & $3.54 \mathrm{E}-03$ & $3.55 \mathrm{E}-03$ & $3.55 \mathrm{E}-03$ & $3.55 \mathrm{E}-03$ \\
\hline $\mathrm{He} 3$ & $9.33 \mathrm{E}-12$ & $3.13 \mathrm{E}-08$ & $5.48 \mathrm{E}-08$ & $4.81 \mathrm{E}-11$ & $5.85 \mathrm{E}-09$ & $1.02 \mathrm{E}-08$ & $5.48 \mathrm{E}-08$ \\
\hline $\mathrm{He} 4$ & $1.07 \mathrm{E}-03$ & $3.34 \mathrm{E}-03$ & $5.29 \mathrm{E}-03$ & $2.00 \mathrm{E}-04$ & $2.40 \mathrm{E}-04$ & $2.80 \mathrm{E}-04$ & $5.29 \mathrm{E}-03$ \\
\hline Helium & 1.07E-03 & 3.34E-03 & $5.29 \mathrm{E}-03$ & 2.00E-04 & 2.40E-04 & $2.80 \mathrm{E}-04$ & $5.29 \mathrm{E}-03$ \\
\hline Hol65 & $5.40 \mathrm{E}-04$ & $5.54 \mathrm{E}-04$ & $5.54 \mathrm{E}-04$ & $5.28 \mathrm{E}-06$ & $5.30 \mathrm{E}-06$ & $5.30 \mathrm{E}-06$ & $5.54 \mathrm{E}-04$ \\
\hline Hol $66 \mathrm{~m}$ & $2.36 \mathrm{E}-06$ & $2.36 \mathrm{E}-06$ & $2.35 \mathrm{E}-06$ & $4.73 \mathrm{E}-09$ & $4.71 \mathrm{E}-09$ & 4.70E-09 & $2.36 \mathrm{E}-06$ \\
\hline Holmium & 5.42E-04 & $5.56 \mathrm{E}-04$ & $5.56 \mathrm{E}-04$ & $5.28 \mathrm{E}-06$ & $5.30 \mathrm{E}-06$ & $5.30 \mathrm{E}-06$ & $5.56 \mathrm{E}-04$ \\
\hline $\mathrm{H} 1$ & 1.61E-03 & $1.61 \mathrm{E}-03$ & $1.61 \mathrm{E}-03$ & $3.08 \mathrm{E}-04$ & $3.08 \mathrm{E}-04$ & $3.08 \mathrm{E}-04$ & $1.61 \mathrm{E}-03$ \\
\hline $\mathrm{H} 2$ & $1.48 \mathrm{E}-05$ & $1.48 \mathrm{E}-05$ & $1.48 \mathrm{E}-05$ & $2.25 \mathrm{E}-06$ & $2.25 \mathrm{E}-06$ & $2.25 \mathrm{E}-06$ & $1.48 \mathrm{E}-05$ \\
\hline $\mathrm{H} 3$ & $3.90 \mathrm{E}-04$ & $2.95 \mathrm{E}-04$ & $2.23 \mathrm{E}-04$ & $3.68 \mathrm{E}-04$ & $2.78 \mathrm{E}-04$ & $2.10 \mathrm{E}-04$ & $3.90 \mathrm{E}-04$ \\
\hline Hydrogen & $2.02 \mathrm{E}-03$ & $1.92 \mathrm{E}-03$ & $1.85 \mathrm{E}-03$ & 6.77E-04 & 5.87E-04 & $5.20 \mathrm{E}-04$ & $2.02 \mathrm{E}-03$ \\
\hline In 113 & $1.85 \mathrm{E}-06$ & $2.33 \mathrm{E}-04$ & $4.13 \mathrm{E}-04$ & $1.16 \mathrm{E}-06$ & $7.75 \mathrm{E}-05$ & $1.38 \mathrm{E}-04$ & $4.13 \mathrm{E}-04$ \\
\hline $\operatorname{In} 114$ & $6.70 \mathrm{E}-12$ & $1.26 \mathrm{E}-23$ & $9.91 \mathrm{E}-35$ & $1.86 \mathrm{E}-13$ & $4.79 \mathrm{E}-25$ & $0.00 \mathrm{E}+00$ & $6.70 \mathrm{E}-12$ \\
\hline In $114 \mathrm{~m}$ & $9.95 \mathrm{E}-08$ & $7.84 \mathrm{E}-19$ & $6.16 \mathrm{E}-30$ & $3.79 \mathrm{E}-09$ & $2.98 \mathrm{E}-20$ & $2.34 \mathrm{E}-31$ & $9.95 \mathrm{E}-08$ \\
\hline $\ln 115$ & $5.63 \mathrm{E}-03$ & $9.09 \mathrm{E}-03$ & $9.09 \mathrm{E}-03$ & $1.15 \mathrm{E}-02$ & $1.29 \mathrm{E}-02$ & $1.29 \mathrm{E}-02$ & $1.29 \mathrm{E}-02$ \\
\hline In $115 \mathrm{~m}$ & $2.26 \mathrm{E}-04$ & $1.46 \mathrm{E}-22$ & $0.00 \mathrm{E}+00$ & $7.39 \mathrm{E}-05$ & $9.04 \mathrm{E}-23$ & $0.00 \mathrm{E}+00$ & $2.26 \mathrm{E}-04$ \\
\hline Indium & $5.85 \mathrm{E}-03$ & 9.32E-03 & $9.50 \mathrm{E}-03$ & $1.16 \mathrm{E}-02$ & $1.30 \mathrm{E}-02$ & $1.30 \mathrm{E}-02$ & $1.30 \mathrm{E}-02$ \\
\hline $\mathrm{I} 127$ & $1.96 \mathrm{E}-01$ & $2.90 \mathrm{E}-01$ & $2.90 \mathrm{E}-01$ & $1.39 \mathrm{E}-01$ & $1.85 \mathrm{E}-01$ & $1.85 \mathrm{E}-01$ & $2.90 \mathrm{E}-01$ \\
\hline I129 & $9.23 \mathrm{E}-01$ & $1.09 \mathrm{E}+00$ & $1.09 \mathrm{E}+00$ & $9.61 \mathrm{E}-01$ & $1.09 E+00$ & $1.09 \mathrm{E}+00$ & $1.09 E+00$ \\
\hline I131 & $1.09 \mathrm{E}+00$ & $0.00 \mathrm{E}+00$ & $0.00 \mathrm{E}+00$ & $9.73 \mathrm{E}-01$ & $0.00 \mathrm{E}+00$ & $0.00 \mathrm{E}+00$ & $1.09 \mathrm{E}+00$ \\
\hline Iodine & $2.21 \mathrm{E}+00$ & $1.38 \mathrm{E}+00$ & $1.38 \mathrm{E}+00$ & $2.07 E+00$ & $1.28 \mathrm{E}+00$ & $1.28 \mathrm{E}+00$ & $2.21 \mathrm{E}+00$ \\
\hline $\mathrm{Fe} 56$ & 7.03E-01 & $7.08 \mathrm{E}-01$ & $7.08 \mathrm{E}-01$ & 4.70E-02 & $4.73 \mathrm{E}-02$ & $4.73 E-02$ & $7.08 \mathrm{E}-01$ \\
\hline Fe57 & $9.88 \mathrm{E}-03$ & $9.88 \mathrm{E}-03$ & $9.88 \mathrm{E}-03$ & $3.36 \mathrm{E}-05$ & $3.36 \mathrm{E}-05$ & $3.36 \mathrm{E}-05$ & $9.88 \mathrm{E}-03$ \\
\hline Fe58 & $8.65 \mathrm{E}-05$ & $8.65 \mathrm{E}-05$ & $8.65 \mathrm{E}-05$ & $1.51 \mathrm{E}-08$ & $1.51 \mathrm{E}-08$ & $1.51 \mathrm{E}-08$ & $8.65 \mathrm{E}-05$ \\
\hline $\mathrm{Fe} 59$ & $2.51 \mathrm{E}-07$ & $1.11 \mathrm{E}-19$ & $4.90 \mathrm{E}-32$ & $2.18 \mathrm{E}-12$ & $9.61 \mathrm{E}-25$ & $4.25 \mathrm{E}-37$ & $2.51 E-07$ \\
\hline Iron & $7.12 E-01$ & 7.17E-01 & $7.17 \mathrm{E}-01$ & $4.70 \mathrm{E}-02$ & 4.73E-02 & 4.73E-02 & $7.17 \mathrm{E}-01$ \\
\hline $\mathrm{Kr} 80$ & $1.14 \mathrm{E}-07$ & $1.17 \mathrm{E}-07$ & $1.17 \mathrm{E}-07$ & $6.70 \mathrm{E}-08$ & $6.74 \mathrm{E}-08$ & $6.74 \mathrm{E}-08$ & $1.17 \mathrm{E}-07$ \\
\hline $\mathrm{Kr} 81$ & $2.41 \mathrm{E}-08$ & $2.41 \mathrm{E}-08$ & $2.41 \mathrm{E}-08$ & $3.85 \mathrm{E}-09$ & $3.85 \mathrm{E}-09$ & $3.85 \mathrm{E}-09$ & $2.41 \mathrm{E}-08$ \\
\hline $\mathrm{Kr} 82$ & $4.03 E-03$ & $4.70 \mathrm{E}-03$ & $4.70 \mathrm{E}-03$ & $3.59 \mathrm{E}-04$ & $3.90 \mathrm{E}-04$ & $3.90 \mathrm{E}-04$ & 4.70E-03 \\
\hline $\mathrm{Kr} 83$ & 8.68E-02 & $8.80 \mathrm{E}-02$ & 8.80E-02 & 4.73E-01 & 4.75E-01 & $4.75 \mathrm{E}-01$ & $4.75 E-01$ \\
\hline $\mathrm{Kr} 84$ & $1.16 \mathrm{E}+00$ & $1.16 \mathrm{E}+00$ & $1.16 \mathrm{E}+00$ & $1.05 E+00$ & $1.05 \mathrm{E}+00$ & $1.05 E+00$ & $1.16 \mathrm{E}+00$ \\
\hline $\mathrm{Kr} 85$ & $2.01 \mathrm{E}-01$ & $1.46 \mathrm{E}-01$ & $1.06 \mathrm{E}-01$ & $2.55 \mathrm{E}-01$ & $1.85 \mathrm{E}-01$ & $1.34 \mathrm{E}-01$ & $2.55 \mathrm{E}-01$ \\
\hline $\mathrm{Kr} 86$ & $1.51 E+00$ & $1.51 \mathrm{E}+00$ & $1.51 \mathrm{E}+00$ & $1.93 \mathrm{E}+00$ & $1.93 E+00$ & $1.93 \mathrm{E}+00$ & $1.93 E+00$ \\
\hline Krypton & $2.97 \mathrm{E}+00$ & $2.91 \mathrm{E}+00$ & $2.87 \mathrm{E}+00$ & $3.71 \mathrm{E}+00$ & $3.64 \mathrm{E}+00$ & $3.59 \mathrm{E}+00$ & $3.71 \mathrm{E}+00$ \\
\hline
\end{tabular}




\begin{tabular}{|c|c|c|c|c|c|c|c|}
\hline \multirow{2}{*}{$\begin{array}{l}\text { Radionuclide/ } \\
\text { Element }\end{array}$} & \multicolumn{3}{|c|}{ Low Enrichment } & \multicolumn{3}{|c|}{ High Enrichment } & \multirow{2}{*}{ MAX } \\
\hline & initial & $5.0 \mathrm{yr}$ & $10.0 \mathrm{yr}$ & initial & $5.0 \mathrm{yr}$ & $10.0 \mathrm{yr}$ & \\
\hline La138 & $5.96 \mathrm{E}-05$ & $5.96 \mathrm{E}-05$ & $5.96 \mathrm{E}-05$ & $5.48 \mathrm{E}-05$ & $5.48 \mathrm{E}-05$ & $5.48 \mathrm{E}-05$ & $5.96 \mathrm{E}-05$ \\
\hline La139 & $8.79 E+00$ & $8.80 \mathrm{E}+00$ & $8.80 \mathrm{E}+00$ & $1.00 \mathrm{E}+01$ & $1.00 E+01$ & $1.00 \mathrm{E}+01$ & $1.00 \mathrm{E}+01$ \\
\hline La140 & $5.20 \mathrm{E}-01$ & $0.00 \mathrm{E}+00$ & $0.00 \mathrm{E}+00$ & $4.51 \mathrm{E}-01$ & $0.00 \mathrm{E}+00$ & $0.00 \mathrm{E}+00$ & $5.20 \mathrm{E}-01$ \\
\hline Lanthanum & $9.31 \mathrm{E}+00$ & $8.80 \mathrm{E}+00$ & $8.80 \mathrm{E}+00$ & $1.05 \mathrm{E}+01$ & $1.00 \mathrm{E}+01$ & $1.00 \mathrm{E}+01$ & $1.05 \mathrm{E}+01$ \\
\hline $\mathrm{Pb} 206$ & $6.60 \mathrm{E}-22$ & $8.13 \mathrm{E}-17$ & $8.58 \mathrm{E}-16$ & $3.50 \mathrm{E}-22$ & $7.35 \mathrm{E}-17$ & $1.34 \mathrm{E}-15$ & $1.34 \mathrm{E}-15$ \\
\hline $\mathrm{Pb} 207$ & $4.35 \mathrm{E}-18$ & $7.96 \mathrm{E}-15$ & $3.66 \mathrm{E}-14$ & $2.99 \mathrm{E}-17$ & $8.39 E-12$ & $6.29 \mathrm{E}-11$ & $6.29 \mathrm{E}-11$ \\
\hline $\mathrm{Pb} 208$ & $2.54 \mathrm{E}-14$ & $2.59 \mathrm{E}-08$ & $1.13 \mathrm{E}-07$ & $4.78 E-14$ & $2.33 \mathrm{E}-09$ & $9.50 \mathrm{E}-09$ & $1.13 \mathrm{E}-07$ \\
\hline $\mathrm{Pb} 209$ & $1.60 \mathrm{E}-18$ & $3.94 \mathrm{E}-18$ & $1.53 \mathrm{E}-17$ & $1.13 \mathrm{E}-19$ & $7.54 \mathrm{E}-18$ & $1.69 \mathrm{E}-17$ & $1.69 \mathrm{E}-17$ \\
\hline $\mathrm{Pb} 210$ & $9.94 \mathrm{E}-17$ & $1.34 \mathrm{E}-15$ & $1.33 \mathrm{E}-14$ & $2.26 \mathrm{E}-17$ & $2.48 \mathrm{E}-15$ & $1.91 \mathrm{E}-14$ & $1.91 \mathrm{E}-14$ \\
\hline $\mathrm{Pb} 211$ & $0.00 \mathrm{E}+00$ & $0.00 \mathrm{E}+00$ & $0.00 \mathrm{E}+00$ & $9.35 \mathrm{E}-20$ & $5.03 \mathrm{E}-16$ & $1.85 \mathrm{E}-15$ & $1.85 \mathrm{E}-15$ \\
\hline $\mathrm{Pb} 212$ & $1.28 \mathrm{E}-15$ & $2.16 \mathrm{E}-11$ & $3.83 \mathrm{E}-11$ & $2.81 \mathrm{E}-15$ & $1.83 \mathrm{E}-12$ & $3.10 \mathrm{E}-12$ & $3.83 \mathrm{E}-11$ \\
\hline Lead & 2.68E-14 & 2.59E-08 & $1.13 E-07$ & $5.06 \mathrm{E}-14$ & $2.34 \mathrm{E}-09$ & $9.57 \mathrm{E}-09$ & $1.13 \mathrm{E}-07$ \\
\hline Li6 & $1.20 \mathrm{E}-07$ & $1.20 \mathrm{E}-07$ & $1.20 \mathrm{E}-07$ & $2.66 \mathrm{E}-06$ & $2.66 \mathrm{E}-06$ & $2.66 \mathrm{E}-06$ & $2.66 \mathrm{E}-06$ \\
\hline $\mathrm{Li7}$ & $7.71 \mathrm{E}-08$ & $7.71 \mathrm{E}-08$ & $7.71 \mathrm{E}-08$ & $7.96 \mathrm{E}-08$ & $7.96 \mathrm{E}-08$ & $7.96 \mathrm{E}-08$ & $7.96 \mathrm{E}-08$ \\
\hline Lithium & $1.97 \mathrm{E}-07$ & $1.97 \mathrm{E}-07$ & $1.97 \mathrm{E}-07$ & $2.74 \mathrm{E}-06$ & $2.74 \mathrm{E}-06$ & $2.74 \mathrm{E}-06$ & $2.74 \mathrm{E}-06$ \\
\hline $\mathrm{Mg} 24$ & $6.10 \mathrm{E}-03$ & $6.39 \mathrm{E}-03$ & $6.39 \mathrm{E}-03$ & $1.17 \mathrm{E}-03$ & $1.20 \mathrm{E}-03$ & $1.20 \mathrm{E}-03$ & $6.39 \mathrm{E}-03$ \\
\hline $\mathrm{Mg} 25$ & $5.13 \mathrm{E}-06$ & $5.13 \mathrm{E}-06$ & $5.13 \mathrm{E}-06$ & $2.40 \mathrm{E}-07$ & $2.40 \mathrm{E}-07$ & $2.40 \mathrm{E}-07$ & $5.13 \mathrm{E}-06$ \\
\hline Mg26 & $1.50 \mathrm{E}-04$ & $1.50 \mathrm{E}-04$ & $1.50 \mathrm{E}-04$ & $2.79 \mathrm{E}-05$ & $2.79 \mathrm{E}-05$ & $2.79 \mathrm{E}-05$ & $1.50 \mathrm{E}-04$ \\
\hline Magnesium & $6.26 \mathrm{E}-03$ & $6.54 E-03$ & $6.54 \mathrm{E}-03$ & $1.20 \mathrm{E}-03$ & $1.23 \mathrm{E}-03$ & $1.23 \mathrm{E}-03$ & $6.54 \mathrm{E}-03$ \\
\hline Mn54 & $1.30 \mathrm{E}-05$ & $2.25 \mathrm{E}-07$ & $3.89 \mathrm{E}-09$ & $2.65 \mathrm{E}-06$ & $4.59 \mathrm{E}-08$ & $7.95 \mathrm{E}-10$ & $1.30 \mathrm{E}-05$ \\
\hline Mn55 & $4.46 \mathrm{E}+00$ & $4.46 E+00$ & $4.46 \mathrm{E}+00$ & $5.13 E+00$ & $5.13 \mathrm{E}+00$ & $5.13 E+00$ & $5.13 E+00$ \\
\hline Manganese & $4.46 \mathrm{E}+00$ & $4.46 \mathrm{E}+00$ & $4.46 \mathrm{E}+00$ & $5.13 E+00$ & $5.13 \mathrm{E}+00$ & $5.13 E+00$ & $5.13 \mathrm{E}+00$ \\
\hline Mo95 & $3.69 \mathrm{E}-01$ & $6.13 E+00$ & $6.13 \mathrm{E}+00$ & $4.34 \mathrm{E}-01$ & $7.01 E+00$ & $7.01 E+00$ & $7.01 \mathrm{E}+00$ \\
\hline Mo96 & $6.39 \mathrm{E}-02$ & $6.56 \mathrm{E}-02$ & $6.56 \mathrm{E}-02$ & $4.56 \mathrm{E}-03$ & $4.65 \mathrm{E}-03$ & $4.65 E-03$ & $6.56 \mathrm{E}-02$ \\
\hline Mo97 & $5.74 \mathrm{E}+00$ & $5.84 \mathrm{E}+00$ & $5.84 \mathrm{E}+00$ & $6.09 \mathrm{E}+00$ & $6.23 \mathrm{E}+00$ & $6.23 \mathrm{E}+00$ & $6.23 \mathrm{E}+00$ \\
\hline Mo98 & $6.29 \mathrm{E}+00$ & $6.29 E+00$ & $6.29 \mathrm{E}+00$ & $6.45 \mathrm{E}+00$ & $6.45 \mathrm{E}+00$ & $6.45 \mathrm{E}+00$ & $6.45 \mathrm{E}+00$ \\
\hline Mo100 & $7.00 \mathrm{E}+00$ & $7.00 \mathrm{E}+00$ & $7.00 \mathrm{E}+00$ & $7.10 \mathrm{E}+00$ & $7.10 \mathrm{E}+00$ & $7.10 \mathrm{E}+00$ & $7.10 \mathrm{E}+00$ \\
\hline Molybdenum & $1.95 \mathrm{E}+01$ & $2.53 \mathrm{E}+01$ & $2.53 \mathrm{E}+01$ & $2.01 \mathrm{E}+01$ & $2.68 \mathrm{E}+01$ & $2.68 \mathrm{E}+01$ & $2.68 \mathrm{E}+01$ \\
\hline $\mathrm{Nd} 142$ & $2.26 \mathrm{E}-01$ & $2.50 \mathrm{E}-01$ & $2.50 \mathrm{E}-01$ & $1.21 \mathrm{E}-02$ & $1.29 \mathrm{E}-02$ & $1.29 \mathrm{E}-02$ & $2.50 \mathrm{E}-01$ \\
\hline $\mathrm{Nd} 143$ & $7.59 \mathrm{E}-01$ & $2.85 \mathrm{E}+00$ & $2.85 \mathrm{E}+00$ & $5.35 \mathrm{E}+00$ & $9.08 \mathrm{E}+00$ & $9.08 \mathrm{E}+00$ & $9.08 \mathrm{E}+00$ \\
\hline $\mathrm{Nd} 144$ & $6.59 \mathrm{E}+00$ & $1.39 \mathrm{E}+01$ & $1.40 \mathrm{E}+01$ & $1.11 \mathrm{E}+00$ & $9.44 \mathrm{E}+00$ & $9.54 \mathrm{E}+00$ & $1.40 \mathrm{E}+01$ \\
\hline $\mathrm{Nd} 145$ & $3.94 \mathrm{E}+00$ & $3.96 \mathrm{E}+00$ & $3.96 \mathrm{E}+00$ & $6.24 \mathrm{E}+00$ & $6.29 \mathrm{E}+00$ & $6.29 \mathrm{E}+00$ & $6.29 E+00$ \\
\hline $\mathrm{Nd} 146$ & $6.69 \mathrm{E}+00$ & $6.69 \mathrm{E}+00$ & $6.69 \mathrm{E}+00$ & $5.11 E+00$ & $5.13 \mathrm{E}+00$ & $5.13 E+00$ & $6.69 \mathrm{E}+00$ \\
\hline Nd147 & $6.99 \mathrm{E}-01$ & $0.00 \mathrm{E}+00$ & $0.00 \mathrm{E}+00$ & $1.10 \mathrm{E}+00$ & $0.00 \mathrm{E}+00$ & $0.00 E+00$ & $1.10 \mathrm{E}+00$ \\
\hline Nd148 & $3.46 \mathrm{E}+00$ & $3.46 \mathrm{E}+00$ & $3.46 \mathrm{E}+00$ & $2.90 \mathrm{E}+00$ & $2.90 \mathrm{E}+00$ & $2.90 \mathrm{E}+00$ & $3.46 \mathrm{E}+00$ \\
\hline Nd150 & $1.26 \mathrm{E}+00$ & $1.26 \mathrm{E}+00$ & $1.26 \mathrm{E}+00$ & $1.11 \mathrm{E}+00$ & $1.11 \mathrm{E}+00$ & $1.11 \mathrm{E}+00$ & $1.26 \mathrm{E}+00$ \\
\hline Neodymium & $2.36 \mathrm{E}+01$ & $3.24 \mathrm{E}+01$ & $3.25 \mathrm{E}+01$ & $2.29 \mathrm{E}+01$ & $3.39 E+01$ & $3.40 \mathrm{E}+01$ & $3.40 \mathrm{E}+01$ \\
\hline $\mathrm{Ne} 20$ & $3.36 \mathrm{E}-16$ & $3.36 \mathrm{E}-16$ & $3.36 \mathrm{E}-16$ & $2.45 \mathrm{E}-18$ & $2.45 \mathrm{E}-18$ & $2.45 \mathrm{E}-18$ & $3.36 \mathrm{E}-16$ \\
\hline $\mathrm{Ne} 21$ & $1.09 \mathrm{E}-08$ & 1.09E-08 & $1.09 \mathrm{E}-08$ & $4.11 \mathrm{E}-10$ & $4.11 \mathrm{E}-10$ & $4.11 \mathrm{E}-10$ & $1.09 \mathrm{E}-08$ \\
\hline $\mathrm{Ne} 22$ & $1.03 \mathrm{E}-10$ & $1.03 \mathrm{E}-10$ & $1.03 \mathrm{E}-10$ & $9.53 \mathrm{E}-13$ & $9.53 \mathrm{E}-13$ & $9.53 \mathrm{E}-13$ & $1.03 \mathrm{E}-10$ \\
\hline Neon & $1.10 \mathrm{E}-08$ & $1.10 \mathrm{E}-08$ & $1.10 \mathrm{E}-08$ & 4.12E-10 & 4.12E-10 & $4.12 \mathrm{E}-10$ & $1.10 \mathrm{E}-08$ \\
\hline Np235 & $9.46 \mathrm{E}-08$ & $3.88 \mathrm{E}-09$ & $1.59 \mathrm{E}-10$ & $4.93 \mathrm{E}-09$ & $2.01 \mathrm{E}-10$ & $8.26 \mathrm{E}-12$ & $9.46 \mathrm{E}-08$ \\
\hline Np236 & $3.30 \mathrm{E}-06$ & $3.29 \mathrm{E}-06$ & $3.29 \mathrm{E}-06$ & $1.74 \mathrm{E}-07$ & $1.74 \mathrm{E}-07$ & $1.74 \mathrm{E}-07$ & $3.30 \mathrm{E}-06$ \\
\hline Np237 & $1.81 E+00$ & $4.98 \mathrm{E}+00$ & $4.98 \mathrm{E}+00$ & $8.33 \mathrm{E}-01$ & $1.28 \mathrm{E}+00$ & $1.28 \mathrm{E}+00$ & $4.98 \mathrm{E}+00$ \\
\hline Np238 & $2.04 \mathrm{E}-01$ & $1.66 \mathrm{E}-12$ & $1.61 \mathrm{E}-12$ & $1.02 \mathrm{E}-02$ & $2.03 \mathrm{E}-13$ & $1.99 \mathrm{E}-13$ & $2.04 \mathrm{E}-01$ \\
\hline Np239 & $1.48 \mathrm{E}+01$ & $1.46 \mathrm{E}-06$ & $1.46 \mathrm{E}-06$ & $1.84 \mathrm{E}-01$ & $1.63 \mathrm{E}-10$ & $1.61 \mathrm{E}-10$ & $1.48 \mathrm{E}+01$ \\
\hline Neptunium & $1.68 \mathrm{E}+01$ & $4.98 \mathrm{E}+00$ & $4.98 \mathrm{E}+00$ & $1.03 E+00$ & $1.28 \mathrm{E}+00$ & $1.28 \mathrm{E}+00$ & $1.68 \mathrm{E}+01$ \\
\hline Ni60 & $2.70 \mathrm{E}-12$ & $5.49 \mathrm{E}-10$ & $8.31 \mathrm{E}-10$ & $6.00 \mathrm{E}-18$ & $7.96 \mathrm{E}-16$ & $1.21 \mathrm{E}-15$ & $8.31 \mathrm{E}-10$ \\
\hline Ni61 & $4.04 \mathrm{E}-12$ & $4.16 \mathrm{E}-12$ & $4.16 \mathrm{E}-12$ & $3.18 \mathrm{E}-19$ & $3.23 \mathrm{E}-19$ & $3.23 \mathrm{E}-19$ & $4.16 \mathrm{E}-12$ \\
\hline
\end{tabular}




\begin{tabular}{|c|c|c|c|c|c|c|c|}
\hline \multirow{2}{*}{$\begin{array}{l}\text { Radionuclide/ } \\
\text { Element }\end{array}$} & \multicolumn{3}{|c|}{ Low Enrichment } & \multicolumn{3}{|c|}{ High Enrichment } & \multirow{2}{*}{ MAX } \\
\hline & initial & $5.0 \mathrm{yr}$ & $10.0 \mathrm{yr}$ & initial & $5.0 \mathrm{yr}$ & $10.0 \mathrm{yr}$ & \\
\hline $\mathrm{Ni} 62$ & $1.46 \mathrm{E}-14$ & $1.46 \mathrm{E}-14$ & $1.46 \mathrm{E}-14$ & $0.00 \mathrm{E}+00$ & $0.00 \mathrm{E}+00$ & $0.00 E+00$ & $1.46 \mathrm{E}-14$ \\
\hline Ni63 & $2.69 \mathrm{E}-16$ & $2.60 \mathrm{E}-16$ & $2.51 \mathrm{E}-16$ & $0.00 \mathrm{E}+00$ & $0.00 \mathrm{E}+00$ & $0.00 \mathrm{E}+00$ & $2.69 \mathrm{E}-16$ \\
\hline Ni64 & $7.33 \mathrm{E}-18$ & $7.33 \mathrm{E}-18$ & $7.33 \mathrm{E}-18$ & $0.00 \mathrm{E}+00$ & $0.00 \mathrm{E}+00$ & $0.00 \mathrm{E}+00$ & $7.33 \mathrm{E}-18$ \\
\hline Nickel & $6.75 \mathrm{E}-12$ & 5.53E-10 & 8.35E-10 & 6.32E-18 & $7.97 \mathrm{E}-16$ & $1.21 \mathrm{E}-15$ & $8.35 \mathrm{E}-10$ \\
\hline $\mathrm{Nb91}$ & $6.21 E-12$ & $6.18 \mathrm{E}-12$ & $6.15 \mathrm{E}-12$ & $2.88 \mathrm{E}-12$ & $2.85 \mathrm{E}-12$ & $2.84 \mathrm{E}-12$ & $6.21 \mathrm{E}-12$ \\
\hline $\mathrm{Nb92}$ & $7.70 \mathrm{E}-10$ & $7.70 \mathrm{E}-10$ & $7.70 \mathrm{E}-10$ & $3.88 \mathrm{E}-10$ & $3.88 \mathrm{E}-10$ & $3.88 \mathrm{E}-10$ & $7.70 \mathrm{E}-10$ \\
\hline $\mathrm{Nb} 93$ & $6.34 \mathrm{E}-08$ & $9.25 \mathrm{E}-07$ & $3.24 \mathrm{E}-06$ & $3.50 \mathrm{E}-08$ & $1.07 \mathrm{E}-06$ & $3.86 \mathrm{E}-06$ & $3.86 \mathrm{E}-06$ \\
\hline $\mathrm{Nb} 93 \mathrm{~m}$ & $1.41 \mathrm{E}-07$ & 7.61 E-06 & $1.36 \mathrm{E}-05$ & $1.45 \mathrm{E}-07$ & $9.20 \mathrm{E}-06$ & $1.65 \mathrm{E}-05$ & $1.65 \mathrm{E}-05$ \\
\hline Nb94 & $2.19 \mathrm{E}-06$ & $2.19 \mathrm{E}-06$ & $2.19 \mathrm{E}-06$ & $1.79 \mathrm{E}-06$ & $1.79 E-06$ & $1.79 \mathrm{E}-06$ & $2.19 \mathrm{E}-06$ \\
\hline $\mathrm{Nb95}$ & $1.07 \mathrm{E}+00$ & $1.45 \mathrm{E}-08$ & $3.75 \mathrm{E}-17$ & $1.17 \mathrm{E}+00$ & $1.68 \mathrm{E}-08$ & $4.33 \mathrm{E}-17$ & $1.17 \mathrm{E}+00$ \\
\hline $\mathrm{Nb95m}$ & $2.79 \mathrm{E}-03$ & $8.01 \mathrm{E}-12$ & $2.06 \mathrm{E}-20$ & $3.11 \mathrm{E}-03$ & $9.25 \mathrm{E}-12$ & $2.39 \mathrm{E}-20$ & $3.11 \mathrm{E}-03$ \\
\hline Niobium & $1.07 E+00$ & 1.07E-05 & 1.91E-05 & $1.17 E+00$ & $1.21 \mathrm{E}-05$ & $2.22 \mathrm{E}-05$ & $1.17 \mathrm{E}+00$ \\
\hline $\mathrm{N} 15$ & $4.03 \mathrm{E}-17$ & $4.03 \mathrm{E}-17$ & $4.03 \mathrm{E}-17$ & $0.00 \mathrm{E}+00$ & $0.00 \mathrm{E}+00$ & $0.00 \mathrm{E}+00$ & $4.03 \mathrm{E}-17$ \\
\hline Nitrogen & 4.03E-17 & $4.03 \mathrm{E}-17$ & 4.03E-17 & $0.00 \mathrm{E}+00$ & $0.00 \mathrm{E}+00$ & $0.00 \mathrm{E}+00$ & 4.03E-17 \\
\hline $\mathrm{O} 18$ & $4.75 \mathrm{E}-11$ & $4.75 \mathrm{E}-11$ & $4.75 \mathrm{E}-11$ & $8.86 \mathrm{E}-14$ & $8.86 \mathrm{E}-14$ & $8.86 \mathrm{E}-14$ & $4.75 \mathrm{E}-11$ \\
\hline Oxygen & $4.75 \mathrm{E}-11$ & $4.75 \mathrm{E}-11$ & 4.75E-11 & 8.86E-14 & $8.86 \mathrm{E}-14$ & 8.86E-14 & $4.75 \mathrm{E}-11$ \\
\hline $\mathrm{Pd} 104$ & $9.16 \mathrm{E}-01$ & $9.16 \mathrm{E}-01$ & $9.16 \mathrm{E}-01$ & $9.76 \mathrm{E}-02$ & $9.76 \mathrm{E}-02$ & $9.76 \mathrm{E}-02$ & $9.16 \mathrm{E}-01$ \\
\hline $\mathrm{Pd} 105$ & $3.03 \mathrm{E}-01$ & $3.46 \mathrm{E}-01$ & $3.46 \mathrm{E}-0 \mathrm{I}$ & $7.76 \mathrm{E}-01$ & $8.14 \mathrm{E}-01$ & $8.14 \mathrm{E}-01$ & $8.14 \mathrm{E}-01$ \\
\hline Pd106 & $2.51 \mathrm{E}+00$ & $4.40 \mathrm{E}+00$ & $4.46 \mathrm{E}+00$ & $3.79 \mathrm{E}-01$ & $8.36 \mathrm{E}-01$ & $8.51 \mathrm{E}-01$ & $4.46 \mathrm{E}+00$ \\
\hline $\mathrm{Pd} 107$ & $1.36 \mathrm{E}+00$ & $1.36 \mathrm{E}+00$ & $1.36 \mathrm{E}+00$ & $1.78 \mathrm{E}-01$ & $1.78 \mathrm{E}-01$ & $1.78 \mathrm{E}-01$ & $1.36 \mathrm{E}+00$ \\
\hline Pd108 & $9.65 \mathrm{E}-01$ & $9.65 \mathrm{E}-01$ & $9.65 \mathrm{E}-01$ & $8.75 \mathrm{E}-02$ & $8.75 \mathrm{E}-02$ & $8.75 \mathrm{E}-02$ & $9.65 \mathrm{E}-01$ \\
\hline $\operatorname{Pd} 110$ & $2.98 \mathrm{E}-01$ & $2.98 \mathrm{E}-01$ & $2.98 \mathrm{E}-01$ & $3.95 \mathrm{E}-02$ & $3.95 \mathrm{E}-02$ & $3.95 \mathrm{E}-02$ & $2.98 \mathrm{E}-01$ \\
\hline Palladium & $6.36 \mathrm{E}+00$ & $8.29 \mathrm{E}+00$ & $8.35 E+00$ & $1.56 \mathrm{E}+00$ & $2.05 E+00$ & $2.07 \mathrm{E}+00$ & $8.35 \mathrm{E}+00$ \\
\hline P31 & $6.56 \mathrm{E}-10$ & $6.79 E-10$ & $6.79 \mathrm{E}-10$ & $5.16 \mathrm{E}-15$ & $5.24 \mathrm{E}-15$ & $5.24 \mathrm{E}-15$ & $6.79 \mathrm{E}-10$ \\
\hline P32 & $3.23 \mathrm{E}-13$ & $5.91 \mathrm{E}-18$ & $5.79 \mathrm{E}-18$ & $0.00 \mathrm{E}+00$ & $0.00 \mathrm{E}+00$ & $0.00 E+00$ & $3.23 \mathrm{E}-13$ \\
\hline Phosphorus & $6.57 \mathrm{E}-10$ & $6.79 \mathrm{E}-10$ & 6.79E-10 & $5.16 \mathrm{E}-15$ & $5.24 \mathrm{E}-15$ & $5.24 \mathrm{E}-15$ & $6.79 \mathrm{E}-10$ \\
\hline Pu236 & $2.64 \mathrm{E}-06$ & $9.93 \mathrm{E}-07$ & $3.00 \mathrm{E}-07$ & $2.21 \mathrm{E}-07$ & $7.41 \mathrm{E}-08$ & $2.24 \mathrm{E}-08$ & $2.64 \mathrm{E}-06$ \\
\hline Pu237 & $3.91 \mathrm{E}-06$ & $2.64 \mathrm{E}-18$ & $1.78 \mathrm{E}-30$ & $6.83 \mathrm{E}-08$ & $4.61 \mathrm{E}-20$ & $3.11 E-32$ & $3.91 \mathrm{E}-06$ \\
\hline $\mathrm{Pu} 238$ & $1.86 \mathrm{E}-01$ & $3.78 \mathrm{E}-01$ & $3.63 \mathrm{E}-01$ & $4.01 \mathrm{E}-02$ & $4.84 \mathrm{E}-02$ & $4.65 \mathrm{E}-02$ & $3.78 \mathrm{E}-01$ \\
\hline Pu239 & $6.04 E+00$ & $2.10 E+01$ & $2.10 E+01$ & $1.44 \mathrm{E}+00$ & $1.63 E+00$ & $1.63 E+00$ & $2.10 \mathrm{E}+01$ \\
\hline $\mathrm{Pu} 240$ & $4.26 E+00$ & $4.41 E+00$ & $4.50 \mathrm{E}+00$ & $1.89 \mathrm{E}-01$ & $1.89 \mathrm{E}-01$ & $1.89 \mathrm{E}-01$ & $4.50 E+00$ \\
\hline $\mathrm{Pu} 241$ & $2.24 \mathrm{E}+00$ & $1.76 \mathrm{E}+00$ & $1.38 \mathrm{E}+00$ & $6.85 \mathrm{E}-02$ & $5.38 \mathrm{E}-02$ & $4.23 \mathrm{E}-02$ & $2.24 E+00$ \\
\hline $\mathrm{Pu} 242$ & $5.25 \mathrm{E}+00$ & $5.25 \mathrm{E}+00$ & $5.25 \mathrm{E}+00$ & $5.04 \mathrm{E}-03$ & $5.04 \mathrm{E}-03$ & $5.04 \mathrm{E}-03$ & $5.25 \mathrm{E}+00$ \\
\hline $\mathrm{Pu} 243$ & $9.08 \mathrm{E}-02$ & $1.93 \mathrm{E}-15$ & $1.93 \mathrm{E}-15$ & $0.00 \mathrm{E}+00$ & $0.00 \mathrm{E}+00$ & $0.00 \mathrm{E}+00$ & $9.08 \mathrm{E}-02$ \\
\hline Pu244 & $7.91 \mathrm{E}-14$ & $5.81 \mathrm{E}-11$ & $1.16 \mathrm{E}-10$ & $0.00 \mathrm{E}+00$ & $0.00 \mathrm{E}+00$ & $0.00 \mathrm{E}+00$ & $1.16 \mathrm{E}-10$ \\
\hline Pu246 & $1.06 \mathrm{E}-17$ & $2.70 \mathrm{E}-18$ & $2.70 \mathrm{E}-18$ & $0.00 \mathrm{E}+00$ & $0.00 \mathrm{E}+00$ & $0.00 \mathrm{E}+00$ & $1.06 \mathrm{E}-17$ \\
\hline Plutonium & $1.81 \mathrm{E}+01$ & $3.28 \mathrm{E}+01$ & $3.25 E+01$ & $1.74 E+00$ & $1.92 \mathrm{E}+00$ & $1.91 \mathrm{E}+00$ & $3.28 \mathrm{E}+01$ \\
\hline Po210 & $2.36 \mathrm{E}-20$ & $1.79 \mathrm{E}-17$ & $2.26 \mathrm{E}-16$ & $9.63 \mathrm{E}-21$ & $3.13 \mathrm{E}-17$ & $3.24 \mathrm{E}-16$ & $3.24 E-16$ \\
\hline Po216 & $4.94 \mathrm{E}-21$ & $8.34 \mathrm{E}-17$ & $1.48 \mathrm{E}-16$ & $1.09 \mathrm{E}-20$ & $7.06 \mathrm{E}-18$ & $1.20 \mathrm{E}-17$ & $1.48 \mathrm{E}-16$ \\
\hline Polonium & $2.86 \mathrm{E}-20$ & 1.01E-16 & $3.74 E-16$ & $2.05 E-20$ & $3.83 \mathrm{E}-17$ & $3.36 \mathrm{E}-16$ & $3.74 \mathrm{E}-16$ \\
\hline $\operatorname{Pr} 141$ & $2.98 E+00$ & $7.43 E+00$ & $7.43 E+00$ & $3.55 \mathrm{E}+00$ & $9.24 \mathrm{E}+00$ & $9.24 \mathrm{E}+00$ & $9.24 \mathrm{E}+00$ \\
\hline $\operatorname{Pr} 143$ & $1.83 E+00$ & $0.00 \mathrm{E}+00$ & $0.00 \mathrm{E}+00$ & $3.36 E+00$ & $0.00 \mathrm{E}+00$ & $0.00 E+00$ & $3.36 E+00$ \\
\hline $\operatorname{Pr} 144$ & $2.04 \mathrm{E}-03$ & $3.66 \mathrm{E}-06$ & $4.31 \mathrm{E}-08$ & 4.53E-04 & $4.18 \mathrm{E}-06$ & $4.91 \mathrm{E}-08$ & $2.04 \mathrm{E}-03$ \\
\hline $\operatorname{Pr} 144 m$ & $1.86 \mathrm{E}-06$ & $2.14 \mathrm{E}-08$ & $2.51 \mathrm{E}-10$ & $2.09 \mathrm{E}-06$ & $2.44 \mathrm{E}-08$ & $2.86 \mathrm{E}-10$ & $2.09 \mathrm{E}-06$ \\
\hline Praseodymium & $4.80 \mathrm{E}+00$ & $7.43 E+00$ & $7.43 \mathrm{E}+00$ & $6.91 \mathrm{E}+00$ & $9.24 \mathrm{E}+00$ & $9.24 \mathrm{E}+00$ & $9.24 \mathrm{E}+00$ \\
\hline Pml45 & $1.03 \mathrm{E}-07$ & $8.51 \mathrm{E}-08$ & $7.00 \mathrm{E}-08$ & $3.49 \mathrm{E}-08$ & $2.89 \mathrm{E}-08$ & $2.38 \mathrm{E}-08$ & $1.03 \mathrm{E}-07$ \\
\hline Pm146 & $4.16 \mathrm{E}-05$ & $2.23 \mathrm{E}-05$ & $1.19 \mathrm{E}-05$ & $1.41 \mathrm{E}-05$ & $7.56 \mathrm{E}-06$ & $4.04 \mathrm{E}-06$ & $4.16 \mathrm{E}-05$ \\
\hline Pm147 & $3.40 \mathrm{E}-01$ & $2.80 \mathrm{E}-01$ & $7.46 \mathrm{E}-02$ & $2.16 \mathrm{E}+00$ & $8.75 \mathrm{E}-01$ & $2.34 \mathrm{E}-01$ & $2.16 \mathrm{E}+00$ \\
\hline $\mathrm{Pm} 148$ & $1.12 \mathrm{E}-02$ & $6.05 E-19$ & $0.00 \mathrm{E}+00$ & $3.20 \mathrm{E}-02$ & $7.09 \mathrm{E}-18$ & $3.45 \mathrm{E}-31$ & $3.20 \mathrm{E}-02$ \\
\hline
\end{tabular}




\begin{tabular}{|c|c|c|c|c|c|c|c|}
\hline \multirow{2}{*}{$\begin{array}{l}\text { Radionuclide6 } \\
\text { Element }\end{array}$} & \multicolumn{3}{|c|}{ Low Enrichment } & \multicolumn{3}{|c|}{ High Enrichment } & \multirow{2}{*}{ MAX } \\
\hline & initial & $5.0 \mathrm{yr}$ & $10.0 \mathrm{yr}$ & initial & $5.0 \mathrm{yr}$ & $10.0 \mathrm{yr}$ & \\
\hline $\mathrm{Pmi} 48 \mathrm{~m}$ & $1.81 \mathrm{E}-03$ & $8.80 \mathrm{E}-17$ & $4.28 \mathrm{E}-30$ & $2.13 \mathrm{E}-02$ & $1.03 \mathrm{E}-15$ & $5.01 \mathrm{E}-29$ & $2.13 \mathrm{E}-02$ \\
\hline Promethium & 3.53E-01 & $2.80 \mathrm{E}-01$ & $7.46 \mathrm{E}-02$ & $2.22 \mathrm{E}+00$ & 8.75E-01 & $2.34 \mathrm{E}-01$ & $2.22 \mathrm{E}+00$ \\
\hline Pa231 & $5.80 \mathrm{E}-10$ & $1.56 \mathrm{E}-09$ & $2.54 \mathrm{E}-09$ & $9.18 \mathrm{E}-08$ & $3.38 \mathrm{E}-06$ & $6.65 \mathrm{E}-06$ & $6.65 \mathrm{E}-06$ \\
\hline $\mathrm{Pa} 233$ & $1.78 \mathrm{E}-08$ & $1.69 \mathrm{E}-07$ & $1.69 \mathrm{E}-07$ & 8.35E-09 & 4.33E-08 & 4.33E-08 & $1.69 \mathrm{E}-07$ \\
\hline Pa234 & $9.81 \mathrm{E}-11$ & $1.65 \mathrm{E}-13$ & $1.65 \mathrm{E}-13$ & $1.88 \mathrm{E}-12$ & $1.46 \mathrm{E}-14$ & $1.46 \mathrm{E}-14$ & $9.81 \mathrm{E}-11$ \\
\hline $\mathrm{Pa} 234 \mathrm{~m}$ & $6.05 \mathrm{E}-13$ & $3.69 \mathrm{E}-13$ & $3.69 \mathrm{E}-13$ & $3.11 \mathrm{E}-14$ & $3.29 \mathrm{E}-14$ & $3.29 \mathrm{E}-14$ & $6.05 \mathrm{E}-13$ \\
\hline Protactinium & $1.84 \mathrm{E}-08$ & $1.70 \mathrm{E}-07$ & $1.71 \mathrm{E}-07$ & $1.00 \mathrm{E}-07$ & $3.42 \mathrm{E}-06$ & $6.69 \mathrm{E}-06$ & $6.69 \mathrm{E}-06$ \\
\hline $\operatorname{Ra} 223$ & $5.78 \mathrm{E}-18$ & $1.63 \mathrm{E}-16$ & $4.19 \mathrm{E}-16$ & $4.51 \mathrm{E}-17$ & $2.43 \mathrm{E}-13$ & $8.94 \mathrm{E}-13$ & $8.94 \mathrm{E}-13$ \\
\hline $\mathrm{Ra} 224$ & $1.12 \mathrm{E}-14$ & $1.89 \mathrm{E}-10$ & $3.34 \mathrm{E}-10$ & $2.46 \mathrm{E}-14$ & $1.60 \mathrm{E}-11$ & $2.70 \mathrm{E}-11$ & 3.34E-10 \\
\hline $\mathrm{Ra} 225$ & $5.31 \mathrm{E}-16$ & $4.64 \mathrm{E}-16$ & $1.80 \mathrm{E}-15$ & $3.14 \mathrm{E}-17$ & $8.86 \mathrm{E}-16$ & $1.99 \mathrm{E}-15$ & $1.99 \mathrm{E}-15$ \\
\hline $\mathrm{Ra} 226$ & $1.65 \mathrm{E}-16$ & $1.80 \mathrm{E}-12$ & $1.34 \mathrm{E}-11$ & $8.78 \mathrm{E}-16$ & $3.75 \mathrm{E}-12$ & $1.56 \mathrm{E}-11$ & $1.56 \mathrm{E}-11$ \\
\hline $\mathrm{Ra} 228$ & 1.83E-19 & $3.88 \mathrm{E}-16$ & $1.28 \mathrm{E}-15$ & $2.45 \mathrm{E}-19$ & $8.18 \mathrm{E}-16$ & $2.71 \mathrm{E}-15$ & $2.71 \mathrm{E}-15$ \\
\hline Radium & $1.19 \mathrm{E}-14$ & $1.91 \mathrm{E}-10$ & $3.47 \mathrm{E}-10$ & $2.56 \mathrm{E}-14$ & 2.00E-11 & 4.35E-11 & $3.47 \mathrm{E}-10$ \\
\hline Rn220 & $1.93 \mathrm{E}-18$ & $3.26 \mathrm{E}-14$ & $5.76 \mathrm{E}-14$ & $4.24 \mathrm{E}-18$ & $2.76 \mathrm{E}-15$ & $4.68 \mathrm{E}-15$ & $5.76 \mathrm{E}-14$ \\
\hline $\operatorname{Rn} 222$ & $8.59 \mathrm{E}-22$ & $1.16 \mathrm{E}-17$ & $8.58 \mathrm{E}-17$ & $4.16 \mathrm{E}-21$ & $2.41 \mathrm{E}-17$ & $1.00 \mathrm{E}-16$ & $1.00 \mathrm{E}-16$ \\
\hline Radon & $1.93 \mathrm{E}-18$ & $3.26 \mathrm{E}-14$ & 5.77E-14 & $4.24 E-18$ & 2.79E-15 & $4.78 \mathrm{E}-15$ & $5.77 \mathrm{E}-14$ \\
\hline Rh102 & 2.63E-06 & 7.94E-07 & $2.40 \mathrm{E}-07$ & $7.83 \mathrm{E}-07$ & $2.36 \mathrm{E}-07$ & $7.16 \mathrm{E}-08$ & 2.63E-06 \\
\hline Rh103 & $4.38 \mathrm{E}-01$ & $3.64 \mathrm{E}+00$ & $3.64 E+00$ & $1.10 \mathrm{E}+00$ & $3.46 \mathrm{E}+00$ & $3.46 \mathrm{E}+00$ & $3.64 E+00$ \\
\hline Rh103m & $3.16 \mathrm{E}-03$ & $3.14 \mathrm{E}-17$ & $3.10 \mathrm{E}-31$ & 2.34E-03 & $2.31 \mathrm{E}-17$ & $2.29 \mathrm{E}-31$ & $3.16 \mathrm{E}-03$ \\
\hline Rh106 & $3.93 \mathrm{E}-05$ & $5.99 \mathrm{E}-08$ & $1.99 \mathrm{E}-09$ & $3.04 \mathrm{E}-06$ & $1.45 \mathrm{E}-08$ & $4.81 \mathrm{E}-10$ & $3.93 \mathrm{E}-05$ \\
\hline Rhodium & 4.41E-01 & $3.64 \mathrm{E}+00$ & $3.64 \mathrm{E}+00$ & $1.10 \mathrm{E}+00$ & $3.46 \mathrm{E}+00$ & $3.46 \mathrm{E}+00$ & $3.64 \mathrm{E}+00$ \\
\hline Rb85 & $7.44 \mathrm{E}-01$ & $8.01 E-01$ & $8.43 \mathrm{E}-01$ & 9.34E-01 & $1.01 \mathrm{E}+00$ & $1.06 \mathrm{E}+00$ & $1.06 \mathrm{E}+00$ \\
\hline $\mathrm{Rb} 86$ & $2.54 \mathrm{E}-03$ & $7.94 \mathrm{E}-33$ & $0.00 \mathrm{E}+00$ & $1.56 \mathrm{E}-04$ & $4.90 \mathrm{E}-34$ & $0.00 \mathrm{E}+00$ & $2.54 \mathrm{E}-03$ \\
\hline $\mathrm{Rb} 87$ & $1.96 \mathrm{E}+00$ & $1.96 E+00$ & $1.96 \mathrm{E}+00$ & $2.51 \mathrm{E}+00$ & $2.53 \mathrm{E}+00$ & $2.53 \mathrm{E}+00$ & $2.53 E+00$ \\
\hline Rubidium & $2.71 \mathrm{E}+00$ & $2.76 \mathrm{E}+00$ & $2.81 \mathrm{E}+00$ & $3.45 \mathrm{E}+00$ & $3.54 E+00$ & $3.59 \mathrm{E}+00$ & $3.59 \mathrm{E}+00$ \\
\hline Ru99 & $1.98 \mathrm{E}-04$ & $3.00 \mathrm{E}-04$ & $3.85 \mathrm{E}-04$ & $2.11 \mathrm{E}-04$ & $3.43 \mathrm{E}-04$ & $4.55 \mathrm{E}-04$ & $4.55 \mathrm{E}-04$ \\
\hline $\mathrm{Ru} 100$ & $1.64 \mathrm{E}+00$ & $1.64 \mathrm{E}+00$ & $1.64 \mathrm{E}+00$ & $1.74 \mathrm{E}-01$ & $1.74 \mathrm{E}-01$ & $1.74 \mathrm{E}-01$ & $1.64 \mathrm{E}+00$ \\
\hline Ru101 & $5.53 \mathrm{E}+00$ & $5.53 \mathrm{E}+00$ & $5.53 \mathrm{E}+00$ & $5.79 E+00$ & $5.79 E+00$ & $5.79 \mathrm{E}+00$ & $5.79 E+00$ \\
\hline Ru102 & $5.79 \mathrm{E}+00$ & $5.79 \mathrm{E}+00$ & $5.79 \mathrm{E}+00$ & $4.96 \mathrm{E}+00$ & $4.96 \mathrm{E}+00$ & $4.96 \mathrm{E}+00$ & $5.79 \mathrm{E}+00$ \\
\hline Ru103 & $3.19 \mathrm{E}+00$ & $3.16 \mathrm{E}-14$ & $3.13 \mathrm{E}-28$ & $2.36 \mathrm{E}+00$ & $2.34 \mathrm{E}-14$ & $2.31 \mathrm{E}-28$ & $3.19 E+00$ \\
\hline $\mathrm{Ru} 104$ & $3.78 \mathrm{E}+00$ & $3.78 \mathrm{E}+00$ & $3.78 E+00$ & $2.19 \mathrm{E}+00$ & $2.19 E+00$ & $2.19 \mathrm{E}+00$ & $3.78 \mathrm{E}+00$ \\
\hline Rul06 & $1.95 \mathrm{E}+00$ & $6.46 \mathrm{E}-02$ & $2.14 \mathrm{E}-03$ & $4.73 \mathrm{E}-01$ & $1.56 \mathrm{E}-02$ & $5.19 \mathrm{E}-04$ & $1.95 \mathrm{E}+00$ \\
\hline Ruthenium & $2.19 \mathrm{E}+01$ & $1.68 \mathrm{E}+01$ & $1.67 \mathrm{E}+01$ & $1.59 \mathrm{E}+01$ & $1.31 \mathrm{E}+01$ & $1.31 \mathrm{E}+01$ & $2.19 \mathrm{E}+01$ \\
\hline Sm145 & $6.23 \mathrm{E}-10$ & $1.50 \mathrm{E}-11$ & $3.64 \mathrm{E}-13$ & $1.55 \mathrm{E}-10$ & $3.74 \mathrm{E}-12$ & $9.03 \mathrm{E}-14$ & $6.23 \mathrm{E}-10$ \\
\hline Sm146 & 1.44E-06 & 8.01E-06 & 1.15E-05 & $3.68 \mathrm{E}-07$ & $2.60 \mathrm{E}-06$ & $3.80 \mathrm{E}-06$ & $1.15 \mathrm{E}-05$ \\
\hline Sm147 & $7.79 \mathrm{E}-03$ & $7.76 \mathrm{E}-01$ & $9.81 \mathrm{E}-01$ & $3.21 \mathrm{E}-02$ & $2.44 E+00$ & $3.08 \mathrm{E}+00$ & $3.08 \mathrm{E}+00$ \\
\hline $\mathrm{Sm} 148$ & $9.49 \mathrm{E}-02$ & $1.08 \mathrm{E}-01$ & $1.08 \mathrm{E}-01$ & $8.64 \mathrm{E}-02$ & $1.40 \mathrm{E}-01$ & $1.40 \mathrm{E}-01$ & $1.40 \mathrm{E}-01$ \\
\hline Sm149 & $7.28 \mathrm{E}-04$ & $1.01 \mathrm{E}-01$ & $1.01 \mathrm{E}-01$ & $4.46 \mathrm{E}-02$ & $1.90 \mathrm{E}-01$ & $1.90 \mathrm{E}-01$ & $1.90 \mathrm{E}-01$ \\
\hline Sm150 & $1.86 \mathrm{E}+00$ & $1.88 \mathrm{E}+00$ & $1.88 \mathrm{E}+00$ & $1.95 E+00$ & $1.95 \mathrm{E}+00$ & $1.95 \mathrm{E}+00$ & $1.95 \mathrm{E}+00$ \\
\hline Sm151 & $2.16 \mathrm{E}-02$ & $4.61 \mathrm{E}-02$ & $4.44 \mathrm{E}-02$ & $1.31 \mathrm{E}-01$ & $1.48 \mathrm{E}-01$ & 1.43E-01 & $1.48 \mathrm{E}-01$ \\
\hline Sm152 & $7.83 \mathrm{E}-01$ & $7.83 \mathrm{E}-01$ & 7.83E-01 & $9.16 \mathrm{E}-01$ & $9.16 \mathrm{E}-01$ & $9.16 \mathrm{E}-01$ & $9.16 \mathrm{E}-01$ \\
\hline Sm154 & $1.04 \mathrm{E}+00$ & $1.04 \mathrm{E}+00$ & $1.04 \mathrm{E}+00$ & $1.36 \mathrm{E}-01$ & $1.36 \mathrm{E}-01$ & $1.36 \mathrm{E}-01$ & $1.04 \mathrm{E}+00$ \\
\hline Samarium & $3.81 E+00$ & $4.73 E+00$ & $4.93 \mathrm{E}+00$ & $3.30 \mathrm{E}+00$ & $5.92 \mathrm{E}+00$ & $6.55 E+00$ & $6.55 \mathrm{E}+00$ \\
\hline $\mathrm{Se} 76$ & $2.39 \mathrm{E}-05$ & $2.78 \mathrm{E}-05$ & $2.78 \mathrm{E}-05$ & $2.45 \mathrm{E}-06$ & 2.63E-06 & $2.63 \mathrm{E}-06$ & $2.78 \mathrm{E}-05$ \\
\hline Se77 & $4.73 \mathrm{E}-03$ & $4.95 \mathrm{E}-03$ & $4.95 \mathrm{E}-03$ & $6.98 \mathrm{E}-03$ & $7.34 \mathrm{E}-03$ & $7.34 \mathrm{E}-03$ & $7.34 \mathrm{E}-03$ \\
\hline Se78 & $2.05 \mathrm{E}-02$ & $2.06 \mathrm{E}-02$ & $2.06 \mathrm{E}-02$ & $1.94 \mathrm{E}-02$ & $1.95 \mathrm{E}-02$ & $1.95 \mathrm{E}-02$ & $2.06 \mathrm{E}-02$ \\
\hline Se79 & $3.56 \mathrm{E}-02$ & $3.56 \mathrm{E}-02$ & $3.56 \mathrm{E}-02$ & $3.98 \mathrm{E}-02$ & $3.99 \mathrm{E}-02$ & $3.99 \mathrm{E}-02$ & $3.99 \mathrm{E}-02$ \\
\hline Se80 & $1.05 \mathrm{E}-01$ & $1.05 \mathrm{E}-01$ & $1.05 \mathrm{E}-01$ & $1.20 \mathrm{E}-01$ & $1.20 \mathrm{E}-01$ & $1.20 \mathrm{E}-01$ & $1.20 \mathrm{E}-01$ \\
\hline Se82 & $2.56 \mathrm{E}-01$ & $2.56 \mathrm{E}-01$ & $2.56 \mathrm{E}-01$ & $3.05 \mathrm{E}-01$ & $3.05 \mathrm{E}-01$ & 3.05E-01 & $3.05 \mathrm{E}-01$ \\
\hline
\end{tabular}


WSRC-TR-98-0022 $\phi^{\prime} 7$

July 1998

Page A.29 of A.34

\begin{tabular}{|c|c|c|c|c|c|c|c|}
\hline \multirow{2}{*}{$\begin{array}{l}\text { Radionuclide/ } \\
\text { Element }\end{array}$} & \multicolumn{3}{|c|}{ Low Enrichment } & \multicolumn{3}{|c|}{ High Enrichment } & \multirow{2}{*}{ MAX } \\
\hline & initial & $5.0 \mathrm{yr}$ & $10.0 \mathrm{yr}$ & initial & $5.0 \mathrm{yr}$ & $10.0 \mathrm{yr}$ & \\
\hline Selenium & $4.22 \mathrm{E}-01$ & 4.22E-01 & $4.22 \mathrm{E}-01$ & 4.91E-01 & 4.91E-01 & $4.91 \mathrm{E}-01$ & $4.91 \mathrm{E}-01$ \\
\hline $\mathrm{Si} 28$ & $2.63 \mathrm{E}+00$ & $2.63 \mathrm{E}+00$ & $2.63 E+00$ & $1.48 \mathrm{E}-01$ & $1.48 \mathrm{E}-01$ & $1.48 \mathrm{E}-01$ & $2.63 E+00$ \\
\hline $\operatorname{Si} 29$ & $2.36 \mathrm{E}-03$ & $2.36 \mathrm{E}-03$ & $2.36 \mathrm{E}-03$ & $6.90 \mathrm{E}-06$ & $6.90 \mathrm{E}-06$ & $6.90 \mathrm{E}-06$ & $2.36 \mathrm{E}-03$ \\
\hline Si30 & $2.31 \mathrm{E}-06$ & $2.31 \mathrm{E}-06$ & $2.31 \mathrm{E}-06$ & $3.36 \mathrm{E}-10$ & $3.36 \mathrm{E}-10$ & $3.36 \mathrm{E}-10$ & $2.31 \mathrm{E}-06$ \\
\hline $\mathrm{Si} 32$ & $2.66 \mathrm{E}-14$ & $2.60 \mathrm{E}-14$ & $2.55 \mathrm{E}-14$ & $0.00 \mathrm{E}+00$ & $0.00 \mathrm{E}+00$ & $0.00 \mathrm{E}+00$ & $2.66 \mathrm{E}-14$ \\
\hline Silicon & $2.63 \mathrm{E}+00$ & $2.63 \mathrm{E}+00$ & $2.63 \mathrm{E}+00$ & $1.48 \mathrm{E}-01$ & $1.48 \mathrm{E}-01$ & $1.48 \mathrm{E}-01$ & $2.63 \mathrm{E}+00$ \\
\hline Ag107 & 4.91E-09 & $7.33 \mathrm{E}-07$ & $1.46 \mathrm{E}-06$ & $1.29 \mathrm{E}-09$ & $9.59 \mathrm{E}-08$ & $1.90 \mathrm{E}-07$ & $1.46 \mathrm{E}-06$ \\
\hline Ag108 & $2.75 \mathrm{E}-10$ & $3.79 \mathrm{E}-15$ & $3.69 \mathrm{E}-15$ & $2.39 \mathrm{E}-12$ & $6.70 \mathrm{E}-17$ & $6.53 \mathrm{E}-17$ & $2.75 \mathrm{E}-10$ \\
\hline Ag108m & $1.26 \mathrm{E}-06$ & $1.23 \mathrm{E}-06$ & $1.19 \mathrm{E}-06$ & $2.23 \mathrm{E}-08$ & $2.18 \mathrm{E}-08$ & $2.11 \mathrm{E}-08$ & $1.26 \mathrm{E}-06$ \\
\hline $\mathrm{Ag} 109$ & $4.14 \mathrm{E}-01$ & $4.60 \mathrm{E}-01$ & $4.60 \mathrm{E}-01$ & $4.30 \mathrm{E}-02$ & $4.39 \mathrm{E}-02$ & $4.39 \mathrm{E}-02$ & $4.60 \mathrm{E}-01$ \\
\hline Ag109m & $3.70 \mathrm{E}-05$ & $6.89 E-17$ & $4.46 \mathrm{E}-18$ & 7.14E-07 & $4.63 \mathrm{E}-19$ & $3.00 \mathrm{E}-20$ & $3.70 \mathrm{E}-05$ \\
\hline Ag1 10 & $1.66 \mathrm{E}-05$ & $1.70 \mathrm{E}-12$ & $1.07 \mathrm{E}-14$ & $9.18 \mathrm{E}-08$ & $1.90 \mathrm{E}-14$ & $1.19 \mathrm{E}-16$ & $1.66 \mathrm{E}-05$ \\
\hline $\mathrm{Ag} 110 \mathrm{~m}$ & $1.74 \mathrm{E}-02$ & $1.10 \mathrm{E}-04$ & $6.90 \mathrm{E}-07$ & $1.95 \mathrm{E}-04$ & $1.22 \mathrm{E}-06$ & $7.70 \mathrm{E}-09$ & $1.74 \mathrm{E}-02$ \\
\hline $\mathrm{AgI} 11$ & $6.54 \mathrm{E}-02$ & $0.00 E+00$ & $0.00 \mathrm{E}+00$ & $5.53 \mathrm{E}-03$ & $0.00 \mathrm{E}+00$ & $0.00 \mathrm{E}+00$ & $6.54 \mathrm{E}-02$ \\
\hline Silver & 4.97E-01 & $4.60 \mathrm{E}-01$ & $4.60 \mathrm{E}-01$ & $4.87 \mathrm{E}-02$ & $4.39 \mathrm{E}-02$ & $4.39 \mathrm{E}-02$ & 4.97E-01 \\
\hline $\mathrm{Na} 23$ & $5.36 \mathrm{E}-10$ & $5.36 \mathrm{E}-10$ & $5.36 \mathrm{E}-10$ & $1.98 \mathrm{E}-11$ & $1.98 \mathrm{E}-11$ & $1.98 \mathrm{E}-11$ & $5.36 \mathrm{E}-10$ \\
\hline Sodium & $5.36 \mathrm{E}-10$ & $5.36 \mathrm{E}-10$ & $5.36 \mathrm{E}-10$ & $1.98 \mathrm{E}-11$ & $1.98 \mathrm{E}-11$ & $1.98 \mathrm{E}-11$ & $5.36 \mathrm{E}-10$ \\
\hline Sr86 & $9.95 \mathrm{E}-04$ & $3.54 \mathrm{E}-03$ & $3.54 \mathrm{E}-03$ & $1.04 \mathrm{E}-04$ & $2.61 \mathrm{E}-04$ & $2.61 \mathrm{E}-04$ & $3.54 \mathrm{E}-03$ \\
\hline Sr87 & $1.48 \mathrm{E}-05$ & $1.50 \mathrm{E}-05$ & $1.50 \mathrm{E}-05$ & 4.41E-06 & 4.41E-06 & $4.41 \mathrm{E}-06$ & $1.50 \mathrm{E}-05$ \\
\hline Sr 88 & $2.86 \mathrm{E}+00$ & $2.86 \mathrm{E}+00$ & $2.86 \mathrm{E}+00$ & $3.64 \mathrm{E}+00$ & $3.65 \mathrm{E}+00$ & $3.65 \mathrm{E}+00$ & $3.65 E+00$ \\
\hline Sr 89 & $2.60 \mathrm{E}+00$ & $3.46 \mathrm{E}-11$ & $4.63 \mathrm{E}-22$ & $3.56 \mathrm{E}+00$ & $4.75 \mathrm{E}-11$ & $6.34 \mathrm{E}-22$ & $3.56 \mathrm{E}+00$ \\
\hline $\operatorname{Sr} 90$ & $4.64 \mathrm{E}+00$ & $4.10 \mathrm{E}+00$ & $3.63 \mathrm{E}+00$ & $6.03 \mathrm{E}+00$ & $5.33 \mathrm{E}+00$ & $4.70 \mathrm{E}+00$ & $6.03 \mathrm{E}+00$ \\
\hline Strontium & $1.01 \mathrm{E}+01$ & $6.97 \mathrm{E}+00$ & $6.49 \mathrm{E}+00$ & $1.32 \mathrm{E}+01$ & $8.98 \mathrm{E}+00$ & $8.35 \mathrm{E}+00$ & $1.32 \mathrm{E}+01$ \\
\hline S32 & $5.16 \mathrm{E}-14$ & $3.75 \mathrm{E}-13$ & $3.75 \mathrm{E}-13$ & $4.15 \mathrm{E}-20$ & $1.54 \mathrm{E}-19$ & $1.54 \mathrm{E}-19$ & $3.75 \mathrm{E}-13$ \\
\hline S33 & $4.03 \mathrm{E}-17$ & $4.11 \mathrm{E}-17$ & $4.11 \mathrm{E}-17$ & $0.00 \mathrm{E}+00$ & $0.00 \mathrm{E}+00$ & $0.00 E+00$ & $4.11 \mathrm{E}-17$ \\
\hline Sulfur & $5.17 \mathrm{E}-14$ & $3.75 E-13$ & $3.75 E-13$ & $4.15 \mathrm{E}-20$ & $1.54 \mathrm{E}-19$ & $1.54 \mathrm{E}-19$ & $3.75 \mathrm{E}-13$ \\
\hline Tc98 & $6.04 \mathrm{E}-05$ & $6.04 \mathrm{E}-05$ & $6.04 \mathrm{E}-05$ & $1.01 \mathrm{E}-05$ & $1.01 \mathrm{E}-05$ & $1.01 \mathrm{E}-05$ & $6.04 \mathrm{E}-05$ \\
\hline Tc99 & $4.65 \mathrm{E}+00$ & $5.19 \mathrm{E}+00$ & $5.19 \mathrm{E}+00$ & $6.28 \mathrm{E}+00$ & $6.84 \mathrm{E}+00$ & $6.84 \mathrm{E}+00$ & $6.84 \mathrm{E}+00$ \\
\hline Technetium & $4.65 \mathrm{E}+00$ & $5.19 \mathrm{E}+00$ & $5.19 \mathrm{E}+00$ & $6.28 \mathrm{E}+00$ & $6.84 \mathrm{E}+00$ & $6.84 \mathrm{E}+00$ & $6.84 \mathrm{E}+00$ \\
\hline Te122 & $1.10 \mathrm{E}-03$ & $1.50 \mathrm{E}-03$ & $1.50 \mathrm{E}-03$ & $7.38 \mathrm{E}-05$ & $8.74 \mathrm{E}-05$ & $8.74 \mathrm{E}-05$ & $1.50 \mathrm{E}-03$ \\
\hline Te123 & $4.23 \mathrm{E}-06$ & $9.73 \mathrm{E}-06$ & $9.73 \mathrm{E}-06$ & $6.20 \mathrm{E}-08$ & $9.33 \mathrm{E}-08$ & 9.33E-08 & $9.73 \mathrm{E}-06$ \\
\hline $\mathrm{Te} 123 \mathrm{~m}$ & $5.50 \mathrm{E}-06$ & $1.40 \mathrm{E}-10$ & $3.56 \mathrm{E}-15$ & $3.13 \mathrm{E}-08$ & $7.96 \mathrm{E}-13$ & $2.03 \mathrm{E}-17$ & $5.50 \mathrm{E}-06$ \\
\hline $\mathrm{Te} 124$ & $1.25 \mathrm{E}-04$ & $1.19 \mathrm{E}-03$ & $1.19 \mathrm{E}-03$ & $1.64 \mathrm{E}-05$ & $8.81 E-05$ & $8.81 \mathrm{E}-05$ & 1.19E-03 \\
\hline Te125 & $6.26 \mathrm{E}-04$ & $4.68 \mathrm{E}-02$ & $5.99 \mathrm{E}-02$ & $5.10 \mathrm{E}-04$ & $3.03 \mathrm{E}-02$ & $3.88 \mathrm{E}-02$ & $5.99 \mathrm{E}-02$ \\
\hline $\mathrm{Te} 125 \mathrm{~m}$ & $1.56 \mathrm{E}-04$ & $2.56 \mathrm{E}-04$ & $7.20 \mathrm{E}-05$ & $1.21 \mathrm{E}-04$ & $1.65 \mathrm{E}-04$ & $4.64 \mathrm{E}-05$ & $2.56 \mathrm{E}-04$ \\
\hline $\mathrm{Te} 126$ & $1.39 \mathrm{E}-03$ & $1.91 \mathrm{E}-03$ & $1.93 \mathrm{E}-03$ & $3.38 \mathrm{E}-04$ & $4.05 \mathrm{E}-04$ & $4.08 \mathrm{E}-04$ & $1.93 \mathrm{E}-03$ \\
\hline Te127 & $4.50 \mathrm{E}-03$ & $1.44 \mathrm{E}-09$ & $1.30 \mathrm{E}-14$ & $1.75 \mathrm{E}-03$ & $8.86 \mathrm{E}-10$ & $8.01 \mathrm{E}-15$ & $4.50 \mathrm{E}-03$ \\
\hline $\mathrm{Te} 127 \mathrm{~m}$ & $3.60 \mathrm{E}-02$ & $4.11 \mathrm{E}-07$ & $3.71 \mathrm{E}-12$ & $2.44 \mathrm{E}-02$ & $2.54 \mathrm{E}-07$ & $2.29 \mathrm{E}-12$ & $3.60 \mathrm{E}-02$ \\
\hline $\mathrm{Te} 128$ & $6.15 \mathrm{E}-01$ & $6.16 \mathrm{E}-01$ & $6.16 \mathrm{E}-01$ & $5.14 \mathrm{E}-01$ & $5.14 \mathrm{E}-01$ & $5.14 \mathrm{E}-01$ & $6.16 \mathrm{E}-01$ \\
\hline $\mathrm{Te} 129$ & $1.91 \mathrm{E}-03$ & $6.31 \mathrm{E}-21$ & $0.00 \mathrm{E}+00$ & $1.30 \mathrm{E}-03$ & $5.05 \mathrm{E}-21$ & $0.00 \mathrm{E}+00$ & $1.91 \mathrm{E}-03$ \\
\hline $\mathrm{Te} 129 \mathrm{~m}$ & $1.56 \mathrm{E}-01$ & $6.84 \mathrm{E}-18$ & $2.96 \mathrm{E}-34$ & $1.25 \mathrm{E}-01$ & $5.48 \mathrm{E}-18$ & $2.38 \mathrm{E}-34$ & $1.56 \mathrm{E}-01$ \\
\hline $\mathrm{Te} 130$ & $2.66 \mathrm{E}+00$ & $2.66 \mathrm{E}+00$ & $2.66 \mathrm{E}+00$ & $2.60 \mathrm{E}+00$ & $2.60 \mathrm{E}+00$ & $2.60 \mathrm{E}+00$ & $2.66 \mathrm{E}+00$ \\
\hline Tellurium & $3.48 \mathrm{E}+00$ & $3.33 \mathrm{E}+00$ & $3.34 \mathrm{E}+00$ & $3.27 \mathrm{E}+00$ & $3.14 \mathrm{E}+00$ & $3.15 \mathrm{E}+00$ & $3.48 \mathrm{E}+00$ \\
\hline Tb159 & $2.78 \mathrm{E}-02$ & $3.15 \mathrm{E}-02$ & $3.15 \mathrm{E}-02$ & $1.85 \mathrm{E}-03$ & $1.90 \mathrm{E}-03$ & $1.90 \mathrm{E}-03$ & $3.15 \mathrm{E}-02$ \\
\hline Tb160 & $1.25 \mathrm{E}-03$ & $3.11 \mathrm{E}-11$ & $7.74 \mathrm{E}-19$ & $2.25 \mathrm{E}-05$ & $5.59 \mathrm{E}-13$ & $1.39 \mathrm{E}-20$ & $1.25 \mathrm{E}-03$ \\
\hline Tb161 & $2.91 \mathrm{E}-03$ & $0.00 \mathrm{E}+00$ & $0.00 E+00$ & $0.00 \mathrm{E}+00$ & $0.00 \mathrm{E}+00$ & $0.00 \mathrm{E}+00$ & $2.91 \mathrm{E}-03$ \\
\hline Terbium & 3.19E-02 & $3.15 \mathrm{E}-02$ & $3.15 E-02$ & $1.87 \mathrm{E}-03$ & $1.90 \mathrm{E}-03$ & $1.90 \mathrm{E}-03$ & $3.19 \mathrm{E}-02$ \\
\hline $\mathrm{T} 1207$ & $0.00 \mathrm{E}+00$ & $0.00 \mathrm{E}+00$ & $0.00 \mathrm{E}+00$ & $1.21 \mathrm{E}-20$ & $6.49 \mathrm{E}-17$ & $2.40 \mathrm{E}-16$ & $2.40 \mathrm{E}-16$ \\
\hline $\mathrm{Tl} 208$ & $2.16 \mathrm{E}-18$ & $3.65 \mathrm{E}-14$ & $6.46 \mathrm{E}-14$ & $4.75 \mathrm{E}-18$ & $3.09 \mathrm{E}-15$ & $5.23 \mathrm{E}-15$ & $6.46 \mathrm{E}-14$ \\
\hline
\end{tabular}




\begin{tabular}{|c|c|c|c|c|c|c|c|}
\hline \multirow{2}{*}{$\begin{array}{l}\text { Radionuclide/ } \\
\text { Element }\end{array}$} & \multicolumn{3}{|c|}{ Low Enrichment } & \multicolumn{3}{|c|}{ High Enrichment } & \multirow{2}{*}{ MAX } \\
\hline & initial & $5.0 \mathrm{yr}$ & $10.0 \mathrm{yr}$ & initial & $5.0 \mathrm{yr}$ & $10.0 \mathrm{yr}$ & \\
\hline Thallium & $2.16 \mathrm{E}-18$ & $3.65 \mathrm{E}-14$ & $6.46 \mathrm{E}-14$ & 4.76E-18 & 3.15E-15 & 5.47E-15 & $6.46 E-14$ \\
\hline Th227 & $1.68 \mathrm{E}-17$ & $2.66 \mathrm{E}-16$ & $6.88 \mathrm{E}-16$ & $1.48 \mathrm{E}-16$ & $3.98 \mathrm{E}-13$ & $1.46 \mathrm{E}-12$ & $1.46 \mathrm{E}-12$ \\
\hline Th228 & $2.86 \mathrm{E}-12$ & $3.66 \mathrm{E}-08$ & $6.49 \mathrm{E}-08$ & $6.55 \mathrm{E}-12$ & $3.10 \mathrm{E}-09$ & $5.25 \mathrm{E}-09$ & $6.49 \mathrm{E}-08$ \\
\hline Th229 & $1.90 \mathrm{E}-12$ & $9.16 \mathrm{E}-11$ & $3.55 \mathrm{E}-10$ & $2.35 \mathrm{E}-12$ & $1.75 \mathrm{E}-10$ & $3.93 \mathrm{E}-10$ & $3.93 \mathrm{E}-10$ \\
\hline Th230 & $2.19 \mathrm{E}-10$ & $1.14 \mathrm{E}-07$ & $4.31 \mathrm{E}-07$ & $2.06 \mathrm{E}-09$ & $1.69 \mathrm{E}-07$ & $3.61 \mathrm{E}-07$ & 4.31E-07 \\
\hline Th231 & $1.84 \mathrm{E}-11$ & $8.15 \mathrm{E}-13$ & $8.26 \mathrm{E}-13$ & $2.80 \mathrm{E}-09$ & $2.75 \mathrm{E}-09$ & $2.75 \mathrm{E}-09$ & $2.80 \mathrm{E}-09$ \\
\hline Th232 & $7.00 \mathrm{E}-08$ & $3.81 \mathrm{E}-06$ & $7.55 \mathrm{E}-06$ & $1.10 \mathrm{E}-07$ & $8.08 \mathrm{E}-06$ & $1.60 \mathrm{E}-05$ & $1.60 \mathrm{E}-05$ \\
\hline Th234 & $9.11 \mathrm{E}-09$ & $1.09 \mathrm{E}-08$ & $1.09 \mathrm{E}-08$ & $7.54 \mathrm{E}-10$ & $9.74 \mathrm{E}-10$ & $9.74 \mathrm{E}-10$ & $1.09 \mathrm{E}-08$ \\
\hline Thorium & $7.94 \mathrm{E}-08$ & $3.97 E-06$ & $8.06 \mathrm{E}-06$ & 1.16E-07 & 8.25E-06 & $1.64 \mathrm{E}-05$ & $1.64 \mathrm{E}-05$ \\
\hline $\operatorname{Tm} 169$ & 8.41E-09 & $1.71 \mathrm{E}-08$ & $1.71 \mathrm{E}-08$ & $2.88 \mathrm{E}-10$ & $4.21 \mathrm{E}-10$ & $4.21 \mathrm{E}-10$ & $1.71 \mathrm{E}-08$ \\
\hline $\operatorname{Tm} 170$ & $9.65 \mathrm{E}-11$ & $5.11 \mathrm{E}-15$ & $2.71 \mathrm{E}-19$ & $8.59 \mathrm{E}-13$ & $4.55 \mathrm{E}-17$ & $2.41 \mathrm{E}-21$ & $9.65 E-11$ \\
\hline $\operatorname{Tm} 171$ & $7.89 \mathrm{E}-09$ & 1.40E-09 & $2.30 \mathrm{E}-10$ & $9.28 \mathrm{E}-10$ & $1.54 \mathrm{E}-10$ & $2.54 \mathrm{E}-11$ & $7.89 \mathrm{E}-09$ \\
\hline Thulium & $1.64 \mathrm{E}-08$ & 1.85E-08 & $1.74 \mathrm{E}-08$ & $1.22 \mathrm{E}-09$ & $5.75 \mathrm{E}-10$ & $4.47 \mathrm{E}-10$ & $1.85 \mathrm{E}-08$ \\
\hline Snl14 & $5.03 \mathrm{E}-08$ & $1.45 \mathrm{E}-07$ & $1.45 \mathrm{E}-07$ & 2.31E-09 & $5.91 \mathrm{E}-09$ & $5.91 \mathrm{E}-09$ & $1.45 \mathrm{E}-07$ \\
\hline Sn115 & $8.29 \mathrm{E}-04$ & $9.75 \mathrm{E}-04$ & $9.75 \mathrm{E}-04$ & $6.60 \mathrm{E}-04$ & $7.08 \mathrm{E}-04$ & $7.08 \mathrm{E}-04$ & $9.75 \mathrm{E}-04$ \\
\hline Snl16 & $1.59 \mathrm{E}-02$ & 1.60E-02 & $1.60 \mathrm{E}-02$ & $1.40 \mathrm{E}-03$ & $1.40 \mathrm{E}-03$ & $1.40 \mathrm{E}-03$ & $1.60 \mathrm{E}-02$ \\
\hline Sn117 & $2.73 \mathrm{E}-02$ & $2.76 \mathrm{E}-02$ & $2.76 \mathrm{E}-02$ & $1.44 \mathrm{E}-02$ & $1.45 \mathrm{E}-02$ & $1.45 \mathrm{E}-02$ & $2.76 \mathrm{E}-02$ \\
\hline $\mathrm{Sn} 117 \mathrm{~m}$ & $2.89 \mathrm{E}-05$ & $0.00 \mathrm{E}+00$ & $0.00 \mathrm{E}+00$ & $1.01 \mathrm{E}-05$ & $0.00 \mathrm{E}+00$ & $0.00 \mathrm{E}+00$ & $2.89 \mathrm{E}-05$ \\
\hline Sn118 & 2.33E-02 & $2.33 \mathrm{E}-02$ & $2.33 \mathrm{E}-02$ & $1.48 \mathrm{E}-02$ & $1.48 \mathrm{E}-02$ & $1.48 \mathrm{E}-02$ & $2.33 \mathrm{E}-02$ \\
\hline Sn119 & 2.43E-02 & $2.44 \mathrm{E}-02$ & $2.44 \mathrm{E}-02$ & 1.65E-02 & $1.65 \mathrm{E}-02$ & $1.65 \mathrm{E}-02$ & $2.44 \mathrm{E}-02$ \\
\hline Snl19m & $9.06 \mathrm{E}-05$ & $1.21 \mathrm{E}-06$ & $1.60 \mathrm{E}-08$ & $5.78 \mathrm{E}-05$ & 7.69E-07 & $1.02 \mathrm{E}-08$ & $9.06 E-05$ \\
\hline Sn 120 & $2.46 \mathrm{E}-02$ & $2.46 \mathrm{E}-02$ & $2.46 \mathrm{E}-02$ & $1.66 \mathrm{E}-02$ & $1.66 \mathrm{E}-02$ & 1.66E-02 & $2.46 \mathrm{E}-02$ \\
\hline Sn121 & $1.28 \mathrm{E}-03$ & $9.83 \mathrm{E}-09$ & $9.23 \mathrm{E}-09$ & $5.49 \mathrm{E}-04$ & $4.81 \mathrm{E}-09$ & $4.51 \mathrm{E}-09$ & $1.28 \mathrm{E}-03$ \\
\hline $\mathrm{Sn} 121 \mathrm{~m}$ & $2.40 \mathrm{E}-04$ & $2.26 \mathrm{E}-04$ & $2.11 \mathrm{E}-04$ & $1.18 \mathrm{E}-04$ & $1.11 \mathrm{E}-04$ & $1.04 \mathrm{E}-04$ & $2.40 \mathrm{E}-04$ \\
\hline Sn122 & $3.14 \mathrm{E}-02$ & $3.14 \mathrm{E}-02$ & $3.14 \mathrm{E}-02$ & $2.14 \mathrm{E}-02$ & $2.14 \mathrm{E}-02$ & $2.14 \mathrm{E}-02$ & $3.14 \mathrm{E}-02$ \\
\hline Sn123 & $2.31 E-03$ & $1.28 \mathrm{E}-07$ & $7.09 \mathrm{E}-12$ & $2.14 \mathrm{E}-03$ & $1.18 \mathrm{E}-07$ & $6.56 \mathrm{E}-12$ & $2.31 \mathrm{E}-03$ \\
\hline Sn124 & $5.33 \mathrm{E}-02$ & $5.33 \mathrm{E}-02$ & $5.33 \mathrm{E}-02$ & $3.68 \mathrm{E}-02$ & $3.68 \mathrm{E}-02$ & $3.68 \mathrm{E}-02$ & $5.33 \mathrm{E}-02$ \\
\hline Sn125 & $6.34 \mathrm{E}-03$ & $0.00 \mathrm{E}+00$ & $0.00 \mathrm{E}+00$ & $3.56 \mathrm{E}-03$ & $0.00 \mathrm{E}+00$ & $0.00 \mathrm{E}+00$ & $6.34 \mathrm{E}-03$ \\
\hline Sn126 & $1.19 \mathrm{E}-01$ & $1.19 \mathrm{E}-01$ & $1.19 \mathrm{E}-01$ & $6.30 \mathrm{E}-02$ & $6.30 \mathrm{E}-02$ & $6.30 \mathrm{E}-02$ & $1.19 \mathrm{E}-01$ \\
\hline Tin & $3.30 \mathrm{E}-01$ & $3.20 \mathrm{E}-01$ & $3.20 \mathrm{E}-01$ & 1.92E-01 & $1.86 \mathrm{E}-01$ & $1.86 \mathrm{E}-01$ & $3.30 \mathrm{E}-01$ \\
\hline Ti47 & $4.49 \mathrm{E}-19$ & $7.11 \mathrm{E}-19$ & 7.11 E-19 & $0.00 \mathrm{E}+00$ & $0.00 \mathrm{E}+00$ & $0.00 \mathrm{E}+00$ & $7.11 \mathrm{E}-19$ \\
\hline Ti48 & $1.20 \mathrm{E}-16$ & $1.58 \mathrm{E}-16$ & $1.58 \mathrm{E}-16$ & $5.56 \mathrm{E}-18$ & $6.28 \mathrm{E}-18$ & $6.28 \mathrm{E}-18$ & $1.58 \mathrm{E}-16$ \\
\hline Ti49 & $5.89 \mathrm{E}-13$ & $5.89 \mathrm{E}-13$ & $5.89 \mathrm{E}-13$ & $2.30 \mathrm{E}-14$ & $2.30 \mathrm{E}-14$ & $2.30 \mathrm{E}-14$ & $5.89 \mathrm{E}-13$ \\
\hline Ti50 & $8.75 \mathrm{E}-13$ & $8.75 \mathrm{E}-13$ & $8.75 \mathrm{E}-13$ & 2.63E-15 & $2.63 \mathrm{E}-15$ & $2.63 \mathrm{E}-15$ & $8.75 E-13$ \\
\hline Titanium & $1.46 \mathrm{E}-12$ & $1.46 \mathrm{E}-12$ & $1.46 \mathrm{E}-12$ & $2.56 \mathrm{E}-14$ & $2.56 \mathrm{E}-14$ & $2.56 \mathrm{E}-14$ & $1.46 \mathrm{E}-12$ \\
\hline $\mathrm{U} 232$ & $1.26 \mathrm{E}-08$ & $2.20 \mathrm{E}-06$ & $2.75 \mathrm{E}-06$ & 1.65E-08 & $1.80 \mathrm{E}-07$ & $2.20 \mathrm{E}-07$ & $2.75 \mathrm{E}-06$ \\
\hline U233 & $1.89 \mathrm{E}-08$ & $8.29 \mathrm{E}-06$ & $1.63 \mathrm{E}-05$ & 7.01E-06 & $9.14 \mathrm{E}-06$ & $1.12 \mathrm{E}-05$ & $1.63 \mathrm{E}-05$ \\
\hline $\mathrm{U} 234$ & $6.98 \mathrm{E}-04$ & $1.56 \mathrm{E}-02$ & $3.00 \mathrm{E}-02$ & $1.10 \mathrm{E}-02$ & $1.30 \mathrm{E}-02$ & $1.48 \mathrm{E}-02$ & $3.00 \mathrm{E}-02$ \\
\hline U235 & $1.98 \mathrm{E}-01$ & $2.00 \mathrm{E}-01$ & $2.04 \mathrm{E}-01$ & $6.78 \mathrm{E}+02$ & $6.78 \mathrm{E}+02$ & $6.78 \mathrm{E}+02$ & $6.78 \mathrm{E}+02$ \\
\hline U236 & $2.58 \mathrm{E}+01$ & $2.58 \mathrm{E}+01$ & $2.58 \mathrm{E}+01$ & $5.48 \mathrm{E}+01$ & $5.48 \mathrm{E}+01$ & $5.48 \mathrm{E}+01$ & $5.48 \mathrm{E}+01$ \\
\hline U237 & $3.15 E+00$ & $5.33 \mathrm{E}-08$ & $4.19 \mathrm{E}-08$ & $4.40 \mathrm{E}-01$ & $1.63 \mathrm{E}-09$ & $1.28 \mathrm{E}-09$ & $3.15 E+00$ \\
\hline U238 & $7.53 \mathrm{E}+02$ & $7.53 \mathrm{E}+02$ & $7.53 \mathrm{E}+02$ & $6.70 \mathrm{E}+01$ & $6.70 \mathrm{E}+01$ & $6.70 \mathrm{E}+01$ & $7.53 \mathrm{E}+02$ \\
\hline Uranium & $7.82 \mathrm{E}+02$ & $7.78 \mathrm{E}+02$ & $7.78 \mathrm{E}+02$ & $8.00 \mathrm{E}+02$ & $7.99 \mathrm{E}+02$ & $7.99 \mathrm{E}+02$ & $8.00 \mathrm{E}+02$ \\
\hline V50 & 8.83E-16 & $8.83 \mathrm{E}-16$ & $8.83 \mathrm{E}-16$ & $4.31 \mathrm{E}-17$ & $4.31 \mathrm{E}-17$ & $4.31 \mathrm{E}-17$ & $8.83 \mathrm{E}-16$ \\
\hline V51 & $4.71 \mathrm{E}-09$ & $4.71 \mathrm{E}-09$ & $4.71 \mathrm{E}-09$ & $9.68 \mathrm{E}-10$ & $9.68 \mathrm{E}-10$ & $9.68 \mathrm{E}-10$ & $4.71 \mathrm{E}-09$ \\
\hline Vanadium & 4.71E-09 & $4.71 \mathrm{E}-09$ & 4.71E-09 & $9.68 \mathrm{E}-10$ & 9.68E-10 & $9.68 \mathrm{E}-10$ & $4.71 E-09$ \\
\hline Ybl70 & $6.04 \mathrm{E}-12$ & $1.02 \mathrm{E}-10$ & $1.02 \mathrm{E}-10$ & $7.33 \mathrm{E}-14$ & $9.31 \mathrm{E}-13$ & $9.31 \mathrm{E}-13$ & $1.02 \mathrm{E}-10$ \\
\hline Yb171 & $1.79 \mathrm{E}-10$ & $7.29 \mathrm{E}-09$ & $8.46 \mathrm{E}-09$ & $2.14 \mathrm{E}-11$ & $8.04 \mathrm{E}-10$ & $9.34 \mathrm{E}-10$ & $8.46 \mathrm{E}-09$ \\
\hline $\mathrm{Yb} 172$ & $1.23 \mathrm{E}-08$ & $1.84 \mathrm{E}-08$ & $1.84 \mathrm{E}-08$ & $7.53 \mathrm{E}-10$ & $8.84 \mathrm{E}-10$ & $8.84 \mathrm{E}-10$ & $1.84 \mathrm{E}-08$ \\
\hline
\end{tabular}




\begin{tabular}{|c|c|c|c|c|c|c|c|}
\hline \multirow{2}{*}{$\begin{array}{l}\text { Radionuclide/ } \\
\text { Element }\end{array}$} & \multicolumn{3}{|c|}{ Low Enrichment } & \multicolumn{3}{|c|}{ High Enrichment } & \multirow{2}{*}{ MAX } \\
\hline & initial & $5.0 \mathrm{yr}$ & $10.0 \mathrm{yr}$ & initial & $5.0 \mathrm{yr}$ & $10.0 \mathrm{yr}$ & \\
\hline Ytterbium & $1.24 \mathrm{E}-08$ & $2.58 \mathrm{E}-08$ & 2.69E-08 & $7.74 \mathrm{E}-10$ & 1.69E-09 & $1.82 \mathrm{E}-09$ & 2.69E-08 \\
\hline Y89 & $1.20 \mathrm{E}+00$ & $3.80 \mathrm{E}+00$ & $3.80 \mathrm{E}+00$ & $1.38 \mathrm{E}+00$ & $4.94 \mathrm{E}+00$ & $4.94 \mathrm{E}+00$ & $4.94 \mathrm{E}+00$ \\
\hline Y89m & $1.68 \mathrm{E}-08$ & $1.19 \mathrm{E}-20$ & $1.58 \mathrm{E}-31$ & $2.78 \mathrm{E}-09$ & $1.63 \mathrm{E}-20$ & $2.16 \mathrm{E}-31$ & $1.68 \mathrm{E}-08$ \\
\hline Y90 & $4.09 \mathrm{E}-03$ & $1.07 \mathrm{E}-03$ & $9.43 \mathrm{E}-04$ & $1.54 \mathrm{E}-03$ & 1.39E-03 & $1.22 \mathrm{E}-03$ & 4.09E-03 \\
\hline Y91 & $3.53 \mathrm{E}+00$ & $1.43 \mathrm{E}-09$ & $5.70 \mathrm{E}-19$ & $4.58 \mathrm{E}+00$ & $1.86 \mathrm{E}-09$ & $7.45 \mathrm{E}-19$ & $4.58 \mathrm{E}+00$ \\
\hline Yttrium & $4.73 E+00$ & $3.80 \mathrm{E}+00$ & $3.80 \mathrm{E}+00$ & $5.95 \mathrm{E}+00$ & $4.94 \mathrm{E}+00$ & $4.94 \mathrm{E}+00$ & $5.95 \mathrm{E}+00$ \\
\hline Xe126 & $2.05 \mathrm{E}-11$ & $2.05 \mathrm{E}-11$ & $2.05 \mathrm{E}-11$ & $8.89 \mathrm{E}-12$ & $8.89 \mathrm{E}-12$ & $8.89 \mathrm{E}-12$ & $2.05 \mathrm{E}-11$ \\
\hline $\mathrm{Xe127}$ & $1.46 \mathrm{E}-08$ & $1.15 \mathrm{E}-23$ & $0.00 \mathrm{E}+00$ & $1.19 \mathrm{E}-10$ & $9.35 \mathrm{E}-26$ & $0.00 \mathrm{E}+00$ & $1.46 \mathrm{E}-08$ \\
\hline $\mathrm{Xe1} 28$ & $1.02 \mathrm{E}-02$ & $1.03 \mathrm{E}-02$ & $1.03 \mathrm{E}-02$ & $5.55 \mathrm{E}-04$ & $5.56 \mathrm{E}-04$ & $5.56 \mathrm{E}-04$ & $1.03 \mathrm{E}-02$ \\
\hline Xe129 & $9.11 \mathrm{E}-05$ & $1.41 \mathrm{E}-04$ & $1.43 \mathrm{E}-04$ & 3.03E-07 & $6.48 \mathrm{E}-07$ & $8.89 \mathrm{E}-07$ & $1.43 \mathrm{E}-04$ \\
\hline $\mathrm{Xe} 129 \mathrm{~m}$ & $5.05 \mathrm{E}-05$ & $0.00 \mathrm{E}+00$ & $0.00 \mathrm{E}+00$ & $1.04 \mathrm{E}-07$ & $0.00 E+00$ & $0.00 \mathrm{E}+00$ & 5.05E-05 \\
\hline Xe130 & $2.00 \mathrm{E}-01$ & $2.10 \mathrm{E}-01$ & $2.10 \mathrm{E}-01$ & $1.00 \mathrm{E}-02$ & $1.03 \mathrm{E}-02$ & $1.03 \mathrm{E}-02$ & $2.10 \mathrm{E}-01$ \\
\hline $\mathrm{Xe} 131$ & $.1 .29 \mathrm{E}+00$ & $2.44 \mathrm{E}+00$ & $2.44 E+00$ & $3.04 \mathrm{E}+00$ & $4.05 E+00$ & $4.05 E+00$ & $4.05 E+00$ \\
\hline Xe131m & $2.11 \mathrm{E}-02$ & $0.00 E+00$ & $0.00 \mathrm{E}+00$ & 1.43E-02 & $0.00 \mathrm{E}+00$ & $0.00 \mathrm{E}+00$ & $2.11 \mathrm{E}-02$ \\
\hline Xe132 & $8.14 \mathrm{E}+00$ & $8.78 \mathrm{E}+00$ & $8.78 \mathrm{E}+00$ & $6.16 \mathrm{E}+00$ & $6.78 \mathrm{E}+00$ & $6.78 \mathrm{E}+00$ & $8.78 \mathrm{E}+00$ \\
\hline Xe134 & $1.36 \mathrm{E}+01$ & $1.36 \mathrm{E}+01$ & $1.36 \mathrm{E}+01$ & $1.21 \mathrm{E}+01$ & $1.21 \mathrm{E}+01$ & $1.21 \mathrm{E}+01$ & $1.36 \mathrm{E}+01$ \\
\hline Xe136 & $1.98 \mathrm{E}+01$ & $1.98 \mathrm{E}+01$ & $1.98 \mathrm{E}+01$ & $1.93 \mathrm{E}+01$ & $1.93 \mathrm{E}+01$ & $1.93 \mathrm{E}+01$ & $1.98 \mathrm{E}+01$ \\
\hline Xenon & $4.30 \mathrm{E}+01$ & $4.48 \mathrm{E}+01$ & $4.48 \mathrm{E}+01$ & $4.05 \mathrm{E}+01$ & $4.22 \mathrm{E}+01$ & $4.22 \mathrm{E}+01$ & $4.48 \mathrm{E}+01$ \\
\hline Zn66 & $3.91 \mathrm{E}-09$ & $4.40 \mathrm{E}-09$ & $4.40 \mathrm{E}-09$ & 2.23E-09 & $2.38 \mathrm{E}-09$ & $2.38 \mathrm{E}-09$ & 4.40E-09 \\
\hline $\mathrm{Zn} 67$ & $5.30 \mathrm{E}-10$ & $5.90 \mathrm{E}-10$ & $5.90 \mathrm{E}-10$ & $3.99 \mathrm{E}-10$ & $4.30 \mathrm{E}-10$ & $4.30 \mathrm{E}-10$ & $5.90 \mathrm{E}-10$ \\
\hline $\mathrm{Zn} 68$ & $4.81 \mathrm{E}-11$ & $4.81 \mathrm{E}-11$ & $4.81 \mathrm{E}-11$ & $2.00 \mathrm{E}-11$ & $2.00 \mathrm{E}-11$ & $2.00 \mathrm{E}-11$ & $4.81 \mathrm{E}-11$ \\
\hline Zn70 & $4.61 \mathrm{E}-08$ & $4.61 \mathrm{E}-08$ & 4.61E-08 & $1.38 \mathrm{E}-08$ & $1.38 \mathrm{E}-08$ & $1.38 \mathrm{E}-08$ & 4.61E-08 \\
\hline Zinc & $5.06 \mathrm{E}-08$ & 5.12E-08 & 5.12E-08 & $1.64 \mathrm{E}-08$ & $1.66 \mathrm{E}-08$ & $1.66 \mathrm{E}-08$ & 5.12E-08 \\
\hline $\mathrm{Zr} 90$ & $1.58 \mathrm{E}-02$ & $5.56 \mathrm{E}-01$ & $1.03 \mathrm{E}+00$ & $9.15 \mathrm{E}-03$ & $7.06 \mathrm{E}-01$ & $1.33 \mathrm{E}+00$ & $1.33 \mathrm{E}+00$ \\
\hline $\mathrm{Zr} 91$ & $1.34 \mathrm{E}+00$ & $4.89 \mathrm{E}+00$ & $4.89 \mathrm{E}+00$ & $1.50 \mathrm{E}+00$ & $6.14 \mathrm{E}+00$ & $6.14 E+00$ & $6.14 \mathrm{E}+00$ \\
\hline Zr92 & $5.15 \mathrm{E}+00$ & $5.16 \mathrm{E}+00$ & $5.16 \mathrm{E}+00$ & $6.20 E+00$ & $6.25 E+00$ & $6.25 E+00$ & $6.25 \mathrm{E}+00$ \\
\hline $\mathrm{Zr} 93$ & $3.65 E+00$ & $3.68 \mathrm{E}+00$ & $3.68 \mathrm{E}+00$ & $4.40 \mathrm{E}+00$ & $4.45 \mathrm{E}+00$ & $4.45 E+00$ & $4.45 E+00$ \\
\hline $\mathrm{Zr} 94$ & $6.10 \mathrm{E}+00$ & $6.10 \mathrm{E}+00$ & $6.10 \mathrm{E}+00$ & $6.90 \mathrm{E}+00$ & $6.90 \mathrm{E}+00$ & $6.90 \mathrm{E}+00$ & $6.90 \mathrm{E}+00$ \\
\hline $\mathrm{Zr} 95$ & $4.68 E+00$ & $1.21 \mathrm{E}-08$ & $3.11 \mathrm{E}-17$ & $5.40 \mathrm{E}+00$ & $1.40 \mathrm{E}-08$ & $3.60 \mathrm{E}-17$ & $5.40 \mathrm{E}+00$ \\
\hline Zr96 & $6.24 \mathrm{E}+00$ & $6.24 \mathrm{E}+00$ & $6.24 \mathrm{E}+00$ & $6.84 \mathrm{E}+00$ & $6.84 E+00$ & $6.84 \mathrm{E}+00$ & $6.84 \mathrm{E}+00$ \\
\hline Zirconium & $2.72 \mathrm{E}+01$ & $2.66 \mathrm{E}+01$ & $2.71 \mathrm{E}+01$ & $3.12 \mathrm{E}+01$ & $3.13 E+01$ & $3.19 \mathrm{E}+01$ & $3.19 \mathrm{E}+01$ \\
\hline
\end{tabular}

As a result of the concern for volatilization of the radionuclide species listed in Table A.9 during melt-dilute treatment, the available vapor pressure data for the radionuclide species present in quantities greater than $10^{-3}$ grams has been compiled in Table A.10. Table A.10 provides the temperature dependence of the vapor pressure for only the elemental radionuclide species-no compound formation between radionuclides or other fuel species is included. However, Table A.11 displays the possible compounds formed between $\mathrm{Al}, \mathrm{U}, \mathrm{Cs}, \mathrm{Rb}, \mathrm{Te}, \mathrm{Ba}, \mathrm{Sr}, \mathrm{I}$, and Tritium. 
Table A.10 Vapor Pressure in Atomspheres

\begin{tabular}{|c|c|c|c|c|c|c|}
\hline \multirow{2}{*}{ Element } & \multicolumn{6}{|c|}{ Temperature, ${ }^{\circ} \mathrm{C}$} \\
\hline & 600 & 700 & 800 & 900 & Range & $\mathbf{T}(\mathbf{m p})$ \\
\hline Aluminum & $2.20 \mathrm{E}-13$ & $1.78 \mathrm{E}-11$ & $6.35 \mathrm{E}-10$ & $1.23 \mathrm{E}-08$ & 660 to 1800 & 660 \\
\hline Americium (sol) & $1.28 \mathrm{E}-10$ & $6.54 \mathrm{E}-09$ & $1.59 \mathrm{E}-07$ & $2.21 \mathrm{E}-06$ & 298 to $\mathrm{mp}$ & 994 \\
\hline Barium (liq) & $4.53 \mathrm{E}-06$ & $4.14 \mathrm{E}-05$ & $2.51 \mathrm{E}-04$ & $1.12 \mathrm{E}-03$ & $\mathrm{mp}$ to 1200 & 725 \\
\hline Cadmium & $1.16 \mathrm{E}-01$ & $5.02 \mathrm{E}-01$ & $1.65 E+00$ & $4.42 \mathrm{E}+00$ & $\mathrm{mp}$ to 650 & 321 \\
\hline Cerium & $2.12 \mathrm{E}-19$ & $6.65 \mathrm{E}-17$ & $7.13 \mathrm{E}-15$ & $3.45 \mathrm{E}-13$ & mp to 2450 & 798 \\
\hline Cesium & $6.00 \mathrm{E}-01$ & $1.69 \mathrm{E}+00$ & $3.94 \mathrm{E}+00$ & $7.94 E+00$ & $m p$ to 550 & 28 \\
\hline Curium & $1.86 \mathrm{E}-16$ & $2.65 \mathrm{E}-14$ & $1.50 \mathrm{E}-12$ & $4.25 \mathrm{E}-11$ & $m p$ to 2200 & 1340 \\
\hline Dysprosium (sol) & $5.54 \mathrm{E}-12$ & $3.14 \mathrm{E}-10$ & $8.28 \mathrm{E}-09$ & $1.24 \mathrm{E}-07$ & 298 to $\mathrm{mp}$ & 1412 \\
\hline Europium (sol) & $9.45 \mathrm{E}-06$ & $1.08 \mathrm{E}-04$ & $7.77 \mathrm{E}-04$ & $3.95 \mathrm{E}-03$ & 298 to $\mathrm{mp}$ & 822 \\
\hline Gadolinium (sol) & $2.23 \mathrm{E}-17$ & $4.27 \mathrm{E}-15$ & $3.07 \mathrm{E}-13$ & $1.07 \mathrm{E}-11$ & 298 to $\mathrm{mp}$ & 1313 \\
\hline Iron & $8.42 \mathrm{E}-17$ & $1.70 \mathrm{E}-14$ & $1.27 \mathrm{E}-12$ & $4.57 \mathrm{E}-11$ & $\mathrm{mp}$ to 2100 & 1535 \\
\hline Lanthanum & $7.53 E-20$ & $2.82 \mathrm{E}-17$ & $3.49 \mathrm{E}-15$ & $1.90 \mathrm{E}-13$ & $\mathrm{mp}$ to 2450 & 918 \\
\hline Magnesium (sol) & $1.29 \mathrm{E}-03$ & $9.84 \mathrm{E}-03$ & $5.09 \mathrm{E}-02$ & $1.97 \mathrm{E}-01$ & 298 to $\mathrm{mp}$ & 649 \\
\hline Manganese (sol) & $1.77 \mathrm{E}-10$ & $8.74 \mathrm{E}-09$ & $2.05 \mathrm{E}-07$ & 2.77E-06 & 298 to $\mathrm{mp}$ & 1244 \\
\hline Molybdenum & $3.41 \mathrm{E}-32$ & $3.60 \mathrm{E}-28$ & $6.68 \mathrm{E}-25$ & $3.40 E-22$ & 298 to 2500 & 2617 \\
\hline Neodymium & $6.11 \mathrm{E}-14$ & $4.46 \mathrm{E}-12$ & $1.46 \mathrm{E}-10$ & $2.64 \mathrm{E}-09$ & $\mathrm{mp}$ to 2000 & 1021 \\
\hline Neptunium & $2.51 \mathrm{E}-21$ & $1.23 \mathrm{E}-18$ & $1.87 \mathrm{E}-16$ & $1.20 \mathrm{E}-14$ & mp to 2500 & 640 \\
\hline Niobium (sol) & $5.56 \mathrm{E}-36$ & $1.53 \mathrm{E}-31$ & $6.26 \mathrm{E}-28$ & $6.18 \mathrm{E}-25$ & 298 to 2500 & 2468 \\
\hline Palladium & $8.38 \mathrm{E}-16$ & $1.07 \mathrm{E}-13$ & $5.56 \mathrm{E}-12$ & $1.47 \mathrm{E}-10$ & $\mathrm{mp}$ to 2100 & 1554 \\
\hline Plutonium & $3.84 \mathrm{E}-16$ & $3.51 \mathrm{E}-14$ & $1.38 \mathrm{E}-12$ & $2.92 \mathrm{E}-11$ & $\mathrm{mp}$ to 2450 & 641 \\
\hline Rhodium & $1.30 \mathrm{E}-24$ & $1.85 \mathrm{E}-21$ & $6.80 \mathrm{E}-19$ & $9.15 \mathrm{E}-17$ & $\mathrm{mp}$ to 2500 & 1965 \\
\hline Samarium & & & & & & 1074 \\
\hline Selenium & $3.11 \mathrm{E}-01$ & $1.20 \mathrm{E}+00$ & $3.62 \mathrm{E}+00$ & $9.02 \mathrm{E}+00$ & $m p$ to $b p$ & 217 \\
\hline Silicon & $6.85 \mathrm{E}-14$ & $6.32 \mathrm{E}-12$ & $2.48 \mathrm{E}-10$ & $5.18 \mathrm{E}-09$ & $m p$ to 3000 & 1410 \\
\hline Silver (sol) & $4.35 \mathrm{E}-11$ & $2.33 \mathrm{E}-09$ & $5.90 \mathrm{E}-08$ & $8.56 \mathrm{E}-07$ & 298 to $\mathrm{mp}$ & 962 \\
\hline Silver & $8.19 \mathrm{E}-11$ & $3.48 \mathrm{E}-09$ & $7.34 \mathrm{E}-08$ & $9.21 \mathrm{E}-07$ & $\mathrm{mp}$ to 1600 & 962 \\
\hline Strontium (sol) & $8.34 \mathrm{E}-26$ & $8.34 \mathrm{E}-26$ & $8.34 \mathrm{E}-26$ & $8.34 \mathrm{E}-26$ & 298 to $\mathrm{mp}$ & 769 \\
\hline Uranium (sol) & $3.35 \mathrm{E}-41$ & $4.59 \mathrm{E}-38$ & $1.60 \mathrm{E}-35$ & $2.00 \mathrm{E}-33$ & 298 to $\mathrm{mp}$ & 1132 \\
\hline Uranium (liq) & $5.32 \mathrm{E}-25$ & $8.33 \mathrm{E}-22$ & $3.18 \mathrm{E}-19$ & $4.27 \mathrm{E}-17$ & $\mathrm{mp}$ to 2500 & 1132 \\
\hline Yttrium (sol) & $4.21 \mathrm{E}-19$ & $1.62 \mathrm{E}-16$ & $2.03 \mathrm{E}-14$ & $1.11 \mathrm{E}-12$ & 298 to $\mathrm{mp}$ & 1552 \\
\hline Yttrium (liq) & $3.13 \mathrm{E}-18$ & $7.75 \mathrm{E}-16$ & $6.88 \mathrm{E}-14$ & $2.84 \mathrm{E}-12$ & $\mathrm{mp}$ to 2300 & 1552 \\
\hline Zirconium (sol) & $3.90 \mathrm{E}-29$ & $1.84 \mathrm{E}-25$ & $1.77 \mathrm{E}-22$ & $5.27 \mathrm{E}-20$ & 298 to $\mathrm{mp}$ & 1852 \\
\hline Zirconium (liq) & $1.27 \mathrm{E}-28$ & $4.68 \mathrm{E}-25$ & $3.73 \mathrm{E}-22$ & $9.53 \mathrm{E}-20$ & mp tp 2500 & 1852 \\
\hline
\end{tabular}


Table A.11 Compounds and Alloys of Various Offgas Species with Uranium and Aluminum

\begin{tabular}{|c|c|c|c|c|c|c|c|c|c|}
\hline & $\mathrm{Al}$ & $\mathrm{U}$ & $\mathrm{Cs}$ & $\mathrm{Rb}$ & $\mathrm{Te}$ & $H^{3}$ & $\mathrm{Ba}$ & $\mathrm{Sr}$ & 1 \\
\hline Al & 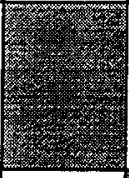 & $\begin{array}{l}\text { Various solubility of } \\
\text { both elements (see } \\
\text { phase diagram); } \mathrm{Al}_{4} \mathrm{U} \\
(\varepsilon) ; \mathrm{Al}_{3} \mathrm{U}(\zeta) ; \mathrm{Al}_{2} \mathrm{U} \\
(\eta)\end{array}$ & $\begin{array}{l}\text { Slight } \\
\text { solubility of } \\
\mathrm{Cs} \text { in Al; no } \\
\text { other phases }\end{array}$ & $\begin{array}{l}\text { No phase } \\
\text { diagram } \\
\text { available but no } \\
\text { compounds } \\
\text { have been } \\
\text { observed } \\
\end{array}$ & $\begin{array}{l}\text { Limited solubility of } \\
\text { both elements; } \\
\mathrm{Al}_{5} \mathrm{Te} ; \mathrm{Al}_{2} \mathrm{Te}_{3}\end{array}$ & $\begin{array}{l}\text { Limited } \\
(\sim \text { zero }) \\
\text { solubility of } \mathrm{H} \\
\text { in Al; no other } \\
\text { phases }\end{array}$ & $\begin{array}{l}\text { Limited solubility of } \mathrm{Ba} \\
\text { in Al but } 5.4 \text { at } \% \\
\text { solubility of } \mathrm{Al} \text { in } \mathrm{Ba} ; \\
\mathrm{Al}_{4} \mathrm{Ba} ; \mathrm{Al}_{2} \mathrm{Ba} ; \mathrm{AlBa} ; \\
\mathrm{AlBa}_{2} \text { phases }\end{array}$ & $\begin{array}{l}\text { Limited solubility } \\
\text { of both elements; } \\
\mathrm{Al}_{4} \mathrm{Sr} ; \mathrm{Al}_{2} \mathrm{Sr} \text {, } \\
\mathrm{Al}_{2} \mathrm{Sr}_{3}\end{array}$ & $\begin{array}{l}\text { No phase } \\
\text { diagram } \\
\text { available }\end{array}$ \\
\hline $\mathrm{U}$ & See Al-U & $y_{1}$ & $\begin{array}{l}\text { No phase } \\
\text { diagram } \\
\text { available }\end{array}$ & $\begin{array}{l}\text { No phase } \\
\text { diagram } \\
\text { available }\end{array}$ & See Te-U & See $H^{3}-U$ & $\begin{array}{l}\text { No phase diagram } \\
\text { available }\end{array}$ & $\begin{array}{l}\text { No phase diagram } \\
\text { available }\end{array}$ & $\begin{array}{l}\text { No phase } \\
\text { diagram } \\
\text { available } \\
\end{array}$ \\
\hline Cs & See Al-Cs & $\begin{array}{l}\text { No phase diagram } \\
\text { available }\end{array}$ & 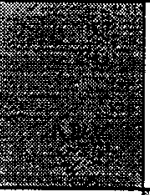 & $\begin{array}{l}\text { Complete } \\
\text { immiscibility of } \\
\text { both elements }\end{array}$ & $\begin{array}{l}\text { Limited solubility of } \\
\text { both elements; } \\
\mathrm{Cs}_{2} \mathrm{Te}_{\mathrm{C}} \mathrm{Cs}_{2} \mathrm{Te}_{2} \\
\mathrm{Cs}_{5} \mathrm{Te}_{4} \text { : } \mathrm{CsTe} \text {; } \\
\mathrm{Cs}_{2} \mathrm{Te}_{3} \text { : } \mathrm{Cs}_{2} \mathrm{Te}_{5} ; \\
\mathrm{CsTe}_{5}\end{array}$ & $\begin{array}{l}\text { No phase } \\
\text { diagram } \\
\text { available; CsH } \\
\text { is formed }\end{array}$ & See Ba-Cs & $\begin{array}{l}\text { Complete } \\
\text { immiscibility of } \\
\text { both elements but } \\
\text { no phase diagram } \\
\text { given }\end{array}$ & $\begin{array}{l}\text { Limited } \\
\text { solubility of } \\
\text { both } \\
\text { elements; } \\
\text { CsI; CsI3; } \\
\mathrm{CsI}_{4}\end{array}$ \\
\hline $\mathrm{Rb}$ & See $A l-R b$ & $\begin{array}{l}\text { No phase diagram } \\
\text { available }\end{array}$ & See Cs-Rb & 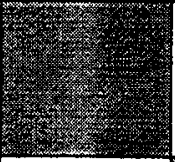 & $\begin{array}{l}\text { Limited solubility of } \\
\text { both elements; } \\
\mathrm{Rb}_{2} \mathrm{Te}_{\mathrm{R}} ; \mathrm{Rb}_{3} \mathrm{Te}_{2} ; \\
\mathrm{Rb}_{5} \mathrm{Te}_{4} ; \mathrm{RbTe} \\
\mathrm{Rb}_{2} \mathrm{Te}_{3} ; \mathrm{Rb}_{2} \mathrm{Te}_{5}\end{array}$ & See $H^{3}-R b$ & See $B a-R b$ & $\begin{array}{l}\text { Complete } \\
\text { immiscibility of } \\
\text { both elements but } \\
\text { no phase diagram } \\
\text { given }\end{array}$ & See I-Rb \\
\hline $\mathrm{Te}$ & See Al-Te & $\begin{array}{l}\text { Limited solubility of } \\
\text { both elements; UTe; } \\
\mathrm{U}_{3} \mathrm{Te}_{4} ; \mathrm{U}_{3} \mathrm{Te}_{5} ; \\
\mathrm{UTe}_{2} ; \mathrm{U}_{3} \mathrm{Te}_{7} ; \\
\mathrm{U}_{2} \mathrm{Te}_{3} ; \mathrm{UTe}_{3} ; \mathrm{UTe}_{5}\end{array}$ & See Cs-Te & See Rb-Te & 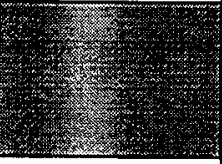 & $\begin{array}{l}\text { No phase } \\
\text { diagram } \\
\text { available }\end{array}$ & See Ba-Te & See Sr-Te & See 1-Te \\
\hline $\mathrm{H}^{3}$ & See $A l-H^{3}$ & $\begin{array}{l}\text { Limited ( } \sim 0 \text { to } 28 \\
\text { wppm) solubility of } \mathrm{H} \\
\text { in various } \mathrm{U} \\
\text { allotropes; } \alpha, \beta, \delta, \varepsilon- \\
\mathrm{UH}_{3}\end{array}$ & See $\mathrm{Cs}-\mathrm{H}^{3}$ & $\begin{array}{l}\text { No phase } \\
\text { diagram } \\
\text { available; } \mathrm{RbH} \\
\text { is formed }\end{array}$ & $\begin{array}{l}\text { No phase diagram } \\
\text { available }\end{array}$ & 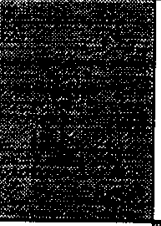 & See $\mathrm{Ba}-\mathrm{H}^{3}$ & $\begin{array}{l}43.2 \text { at } \% \text { solubility } \\
\text { of } \mathrm{H} \text { in } \beta-\mathrm{Sr} ; 4.3 \\
\text { at. } \% \text { solubility of } \mathrm{H} \\
\text { in } \alpha-\mathrm{Sr} ; \alpha \text { and } \beta- \\
\mathrm{SrH}_{2}\end{array}$ & $\begin{array}{l}\text { No phase } \\
\text { diagram } \\
\text { available; HI } \\
\text { may be } \\
\text { possible but } \\
\text { no reference } \\
\text { has been } \\
\text { found }\end{array}$ \\
\hline $\mathrm{Ba}$ & See Al-Ba & $\begin{array}{l}\text { No phase diagram } \\
\text { available }\end{array}$ & $\begin{array}{l}\text { Complete } \\
\text { immiscibility } \\
\text { of both } \\
\text { elements but } \\
\text { no phase } \\
\text { diagram given }\end{array}$ & $\begin{array}{l}\text { Complete } \\
\text { immiscibility of } \\
\text { both elements } \\
\text { but no phase } \\
\text { diagram given }\end{array}$ & $\begin{array}{l}\text { Limited solubility of } \\
\text { both elements; } \mathrm{BaTe} \\
\mathrm{Ba}_{2} \mathrm{Te}_{3} ; \mathrm{BaTe}_{2}\end{array}$ & $\begin{array}{l}\text { Large } \\
\text { solubility of } \mathrm{H} \\
\text { in } \mathrm{Ba} \\
(57 \text { at. } \% \text { at } \\
\left.950^{\circ} \mathrm{C}\right) ; \alpha- \\
\mathrm{BaH}_{2} ; \beta- \\
\mathrm{BaH}_{2}\end{array}$ & 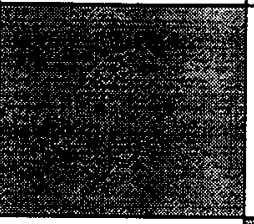 & $\begin{array}{l}\text { Two solid solutions } \\
\text { formed; no other } \\
\text { phases }\end{array}$ & $\begin{array}{l}\text { Limited } \\
\text { solubility of } \\
\text { both } \\
\text { elements; } \\
\mathrm{BaI}_{2}\end{array}$ \\
\hline$S r$ & See AI-Sr & $\begin{array}{l}\text { No phase diagram } \\
\text { available but no } \\
\text { compounds have been } \\
\text { observed }\end{array}$ & See Cs-Sr & See Rb-Sr & $\begin{array}{l}\text { Limited solubility of } \\
\text { both elements; } \mathrm{SrTe} \text {; } \\
\mathrm{Sr}_{2} \mathrm{Te}_{3} ; \mathrm{SrTe}_{2}\end{array}$ & $\operatorname{See} \mathrm{H}^{3}-\mathrm{Sr}$ & See Ba-Sr & & See I-Sr \\
\hline I & $\begin{array}{l}\text { No phase } \\
\text { diagram } \\
\text { available }\end{array}$ & $\begin{array}{l}\text { No phase diagram } \\
\text { available }\end{array}$ & See Cs-I & $\begin{array}{l}\text { Limited } \\
\text { solubility of } \\
\text { both elements; } \\
\mathrm{RbI} \mathrm{RbI}_{3}\end{array}$ & $\begin{array}{l}\text { Limited soiubility of } \\
\text { both elements; TeI; } \\
\mathrm{TeI}_{4}\end{array}$ & See $H^{3}-I$ & See Ba-I & $\begin{array}{l}\text { Limited solubility } \\
\text { of both elements; } \\
\mathrm{SrI}_{2}\end{array}$ & 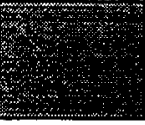 \\
\hline
\end{tabular}

\section{A.5 References}

1 Duguid, J. O., J. A. McNeish, V. Vallikat, D. Cresap, and N. J. Erb. Total System Performance Assessment Sensitivity Studies of U.S. Department of Energy Spent Nuclear Fuel, DI A00000000-01717-5705-00017, Rev. 01 (September 30, 1997).

2 Final Programmatic Spent Nuclear Fuel Management and Idaho National Engineering Environmental Restoration and Waste Management Programs Environmental Impact Statement. DOE (U.S. Department of Energy), DOE/EIS-0203, Idaho Operations Office, Idaho Falls, Idaho (1995). 
3 H. M. Brooks and R. L. Sindelar, WSRC-MS-98-00452, "Characterization of FRR SNF in Basin and Dry Storage Systems," to be presented at the American Nuclear Society - Third Topical Meeting DOE Spent Nuclear Fuel and Fissile Materials Management, Charleston, South Carolinia, September 8-11, 1998.

4 S. D. Burke to R. J. Skwarek, "Proposed New Criteria for Acceptance of Al-SNF for SRS Basin Storage (U)," SRS-RSE-970167, February 11. 1998. 


\section{WESTINGHOUSE SAVANNAH RIVER CO. REPORT WSRC-TR-98-00227}

\section{DISTRIBUTION}

\section{SAVANNAH RIVER SITE}

W. Poulson, 704-C

S. Wood, 773-A

G. T. Wright, 773-A

G. H. Clare, 704-C

M. W. Barlow, 704-C

E. R. Conatser, 704-C

M. E. Dupont, 707-C

R. J. Skwarek, 704-C

H. Brooks, 707-C

W. F. Swift, 707-C

S. D. Burke, 707-C

D. Bickley, 707-C

S. Large, 707-C

G. Reynolds, 704-C

T. J. Worrell, 705-K

C. R. Wolfe, 773-A

J. D. Cohen, 773-A

T. L. Capeletti, 773-41A

C. Holding-Smith, 773-42A

N. C. Iyer, 773-A

M. R. Louthan, Jr., 773-A

J. F. Krupa, 773-41A

J. P. Howell, 773-41A

H. B. Peacock, Jr., 773-A

D. R. Leader, 773-A

F. C. Rhode, 773-A

D. L. Fisher, 773-41A

T. M. Adams, 773-41A

M. E. Hodges, 773-41A

P. J. French, 773-23A

S. Y. Lee, 773-42A

P. E. Zapp, 773-A

B. Cederdahl, 707-C

L. Lamm, 707-C

W. Bugher, 707-C

A. Brewer, 707-C
J. I. Mickalonis, 773-A

P. S. Lam, 773-41A

W. Epling, 707-C

B. J. Wiersma, 773-A

G. T. Chandler, 773-A

W. F Ayres, 773-41A

R. L. Sindelar, 773-41A

D. W. Vinson, 773-41A

DOE-SR (10 copies)/J. M. Ridley, 707-K

Site Records, 773-52A 